ФЕДЕРАЛЬНЫЙ ИССЛЕДОВАТЕЛЬСКИЙ ЦЕНТР

КОЛЬСКИЙ НАЧЧНЫЙ ІЕНТР

92

ИНСТИТУТ ЭКОНОМИЧЕСКИХ ПРОБЛЕМ ИМ. Г.П. ЛУЗИНА ФЕДЕРАЛЬНОГО ИССЛЕДОВАТЕЛЬСКОГО ЦЕНТРА «КОЛЬСКИЙ НАУЧНЫЙ ЦЕНТР РОССИЙСКОЙ АКАДЕМИИ НАУК»

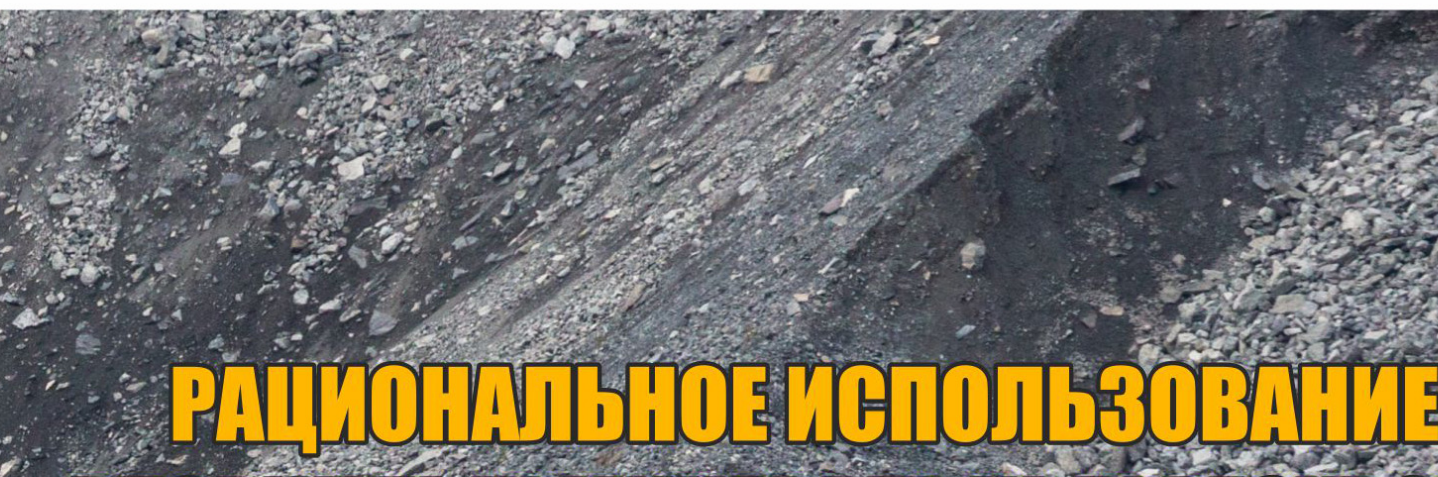

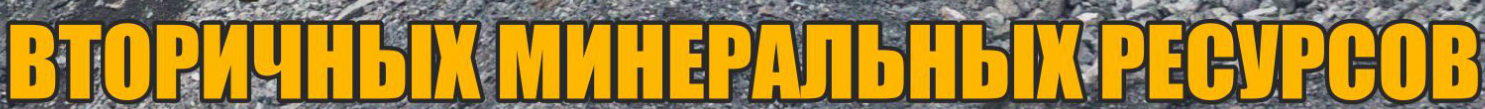

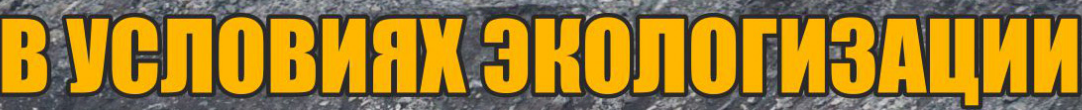

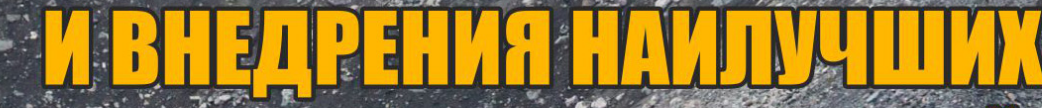

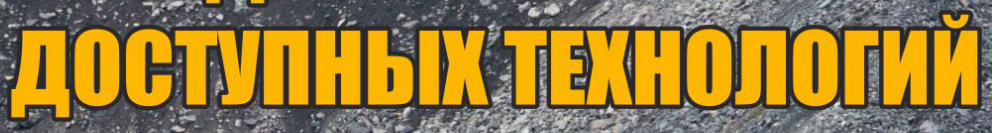
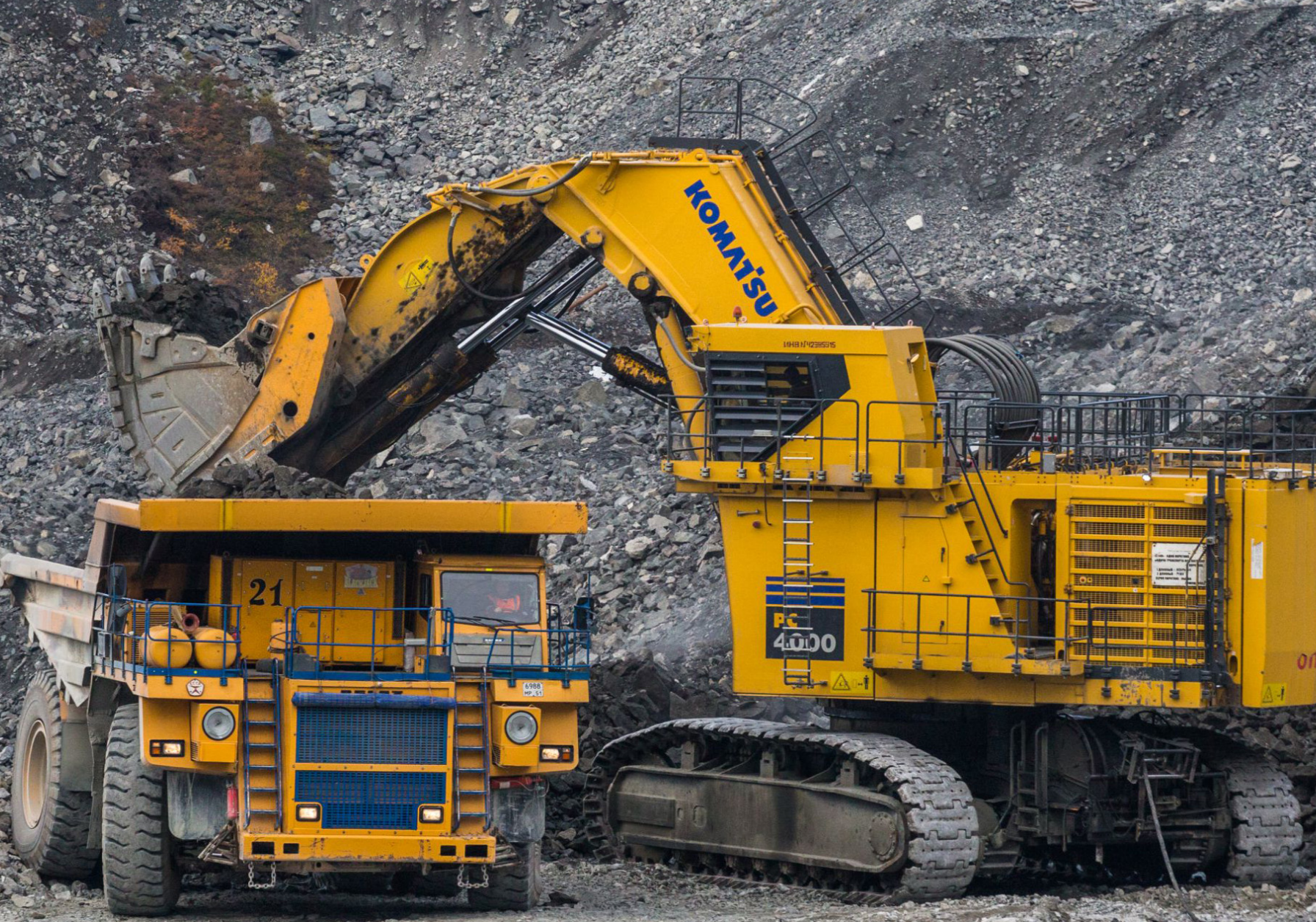
МИНИСТЕРСТВО НАУКИ И ВЫСШЕГО ОБРАЗОВАНИЯ РОССИЙСКОЙ ФЕДЕРАЦИИ

ФЕДЕРАЛЬНЫЙ ИССЛЕДОВАТЕЛЬСКИЙ ЦЕНТР

«КОЛЬСКИЙ НАУЧНЫЙ ЦЕНТР РОССИЙСКОЙ АКАДЕМИИ НАУК»

ИНСТИТУТ ЭКОНОМИЧЕСКИХ ПРОБЛЕМ ИМ. Г. П. ЛУЗИНА

\section{РАЦИОНАЛЬНОЕ ИСПОЛЬЗОВАНИЕ ВТОРИЧНЫХ МИНЕРАЛЬНЫХ РЕСУРСОВ В УСЛОВИЯХ ЭКОЛОГИЗАЦИИ И ВНЕДРЕНИЯ НАИЛУЧШИХ ДОСТУПНЫХ ТЕХНОЛОГИЙ}

Под научной редакцией профессора Ф. Д. Ларичкина, профессора В. А. Кныша

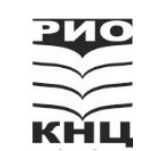

Издательство Кольского научного центра 2019 
DOI: $10.37614 / 978.5 .91137 .417 .4$

УДК 338.45:622.47

ББК 65.304.11:30.69

P12

Печатается по решению Редакционного совета по книжным изданиям ФИЦ КНЦ РАН Рецензенты:

доктор экономических наук, профессор, заведующий кафедрой экономической теории ФГБОУ ВО «Санкт-Петербургский горный университет» М. М. Хайкин,

доктор экономических наук, доцент, заведующая кафедрой экономики и менеджмента ФГБОУ ВО «Уральский государственный горный университет» Л. А. Мочалова Коллектив авторов:

В. А. Кныш, Ф. Д. Ларичкин, М. А. Невская, С. В. Федосеев,

Т. А. Блошенко, И. В. Мелик-Гайказов, В. Н. Переин,

В. Д. Новосельцева, Л. И. Гончарова, А. А. Гилярова

Рациональное использование вторичных минеральных ресурсов в условиях

P12 экологизации и внедрения наилучших доступных технологий : монография / коллектив авторов ; под науч. ред. д. э. н., проф. Ф. Д. Ларичкина, д. э. н., проф. В. А. Кныша. - Апатиты : Издательство ФИЦ КНЦ РАН, 2019. — 252 с. : ил. + Прил. ISBN 978-5-91137-417-4

Выполнен анализ тенденций в области образования и использования отходов добычи и обогащения полезных ископаемых, выявлены причины роста накоплений отходов. Рассмотрена проблема вовлечения техногенных отходов в хозяйственный оборот, дана оценка возможности ее решения с учетом противоречий горного и экологического законодательств. Предложены меры по стимулированию вовлечения отходов в хозяйственный оборот путем введения дифференцированных ставок по налогу на добычу полезных ископаемых (НДПИ) при переработке многокомпонентных руд, создания системы кадастров и автоматизированных баз данных, развития институциональной среды управления техногенными ресурсами. Выполнен ретроспективный анализ концепций рационального недропользования, исследован и дополнен авторскими дефинициями понятийный аппарат. С помощью уравнений баланса горной массы выделены безвозвратные отходы и техногенные минеральные ресурсы. Уточнена и дополнена классификация техногенных отходов, предложена типология техногенных минеральных объектов. Рассмотрен методический аппарат оценки экономической эффективности комплексного использования минерального сырья. Его применимость проиллюстрирована расчетом эффективности освоения разведанных запасов техногенного месторождения ОАО «Ковдорский ГОК». Описана система экологического регулирования на основе наилучших доступных технологий (НДТ), дана оценка ее применимости в отраслях добычи полезных ископаемых. Рассмотрена европейская модель борьбы с промышленными загрязнениями, положенная в основу реформируемой российской системы регулирования. Сделан вывод, что в российских условиях внедрение механизма НДТ важно не только в аспекте снижения уровня загрязнения окружающей среды, но и в аспекте технологического развития горнопромышленных компаний. Описаны новации регулирования на основе механизма НДТ, технологического нормирования и выдачи комплексных экологических разрешений (КЭР). Дана оценка справочникам по НДТ, областью применения которых является горнодобывающая промышленность. Приведены особенности расчета технологических нормативов, структура заявок на получение КЭР и деклараций по объектам II категории.

Издание предназначено для руководителей и специалистов, занятых в секторе добычи полезных ископаемых, преподавателей и студентов профильных вузов.

Научное издание

Редактор Е. Н. Еремеева

Технический редактор В. Ю. Жиганов

Подписано в печать 24.12.2019. Формат бумаги 70×108 1/16.

Усл. печ. л. 22.05. Заказ № 6. Тираж 500 экз. 


\section{ОГЛАВЛЕНИЕ}

СПИСОК ПРИНЯТЫХ СОКРАЩЕНИЙ...............................

1. ПРОБЛЕМА ИСПОЛЬЗОВАНИЯ НАКОПЛЕННОГО РЕСУРСНОГО ПОТЕНЦИАЛА ОТХОДОВ ГОРНОГО ПРОИЗВОДСТВА В УСЛОВИЯХ ЭКОЛОГИЗАЦИИ.

1.1. Анализ тенденций в сфере образования и использования отходов горного производства

1.1.1. Рациональное использование ресурсов недр - один из принципов устойчивого развития.

1.1.2. Ресурсный потенциал и опыт переработки горнопромышленных отходов.

1.1.3. Динамика образования, использования и накопления

горнопромышленных отходов: экологический фактор.

1.1.4. Основные причины роста накоплений отходов добычи и первичной переработки полезных ископаемых.

1.2. Проблема вовлечения отходов недропользования в хозяйственный оборот и пути ее решения.

1.2.1. Несовершенство систем оценки и учета горнопромышленных отходов.

1.2.2. Противоречия в вопросах права собственности и использования отходов горнодобывающих производств.

1.2.3. Анализ методов и инструментов государственного регулирования в области использования отходов горного производства.

1.2.4. Формирование институциональной среды управления отходами горнодобывающих производств в условиях экологизации и внедрения наилучших доступных технологий.

1.3. Совершенствование налоговой политики в области комплексного использования минерального сырья и отходов его переработки........... 1.3.1. Сочетание фискальной и регулирующей функций налогов с целью наиболее полного извлечения полезных компонентов из минерального сырья.

1.3.2. Предложения по установлению дифференцированных ставок по налогу на добычу полезных ископаемых для твердых полезных ископаемых при добыче многокомпонентных руд. . .

1.3.3. Модель расчета дифференцированных ставок по налогу на добычу полезных ископаемых для многокомпонентного природного и техногенного минерального сырья.

1.4. Формирование системы кадастров и баз данных техногенных месторождений.

1.4.1. Проблемы и задачи кадастровой оценки техногенных минеральных объектов.

1.4.2. Методические подходы к созданию кадастра горнопромышленных отходов в Мурманской области.

1.4.3. Формирование автоматизированной базы данных по техногенному минеральному сырью в Мурманской области............. 58 Выводы по главе 1 ..................................................... 61 
2. ЭЛЕМЕНТЫ МЕТОДОЛОГИИ ОБЕСПЕЧЕНИЯ РАЦИОНАЛЬНОГО ИСПОЛЬЗОВАНИЯ ВТОРИЧНЫХ

МИНЕРАЛЬНЫХ РЕСУРСОВ.

2.1. Этапы развития научных взглядов на проблему рационального использования и охраны ресурсов недр.

2.1.1. Появление и сущность двух концепций рационального использования ресурсов недр (1960 гг. — конец 1980-х гг.).

2.1.2. Направления развития концепций недропользования в начале становления рыночных отношений (1990 гг. — начало 2000

гг.).

2.1.3. Последующее развитие концепций рационального использования ресурсов недр и обращения с отходами горного производства (2000 г.

- настоящее время).

2.2. Формирование понятийного аппарата в области управления

техногенными минеральными ресурсами.

2.2.1. Потенциальные минеральные ресурсы как объект

управления.

2.2.2. Вторичные минеральные ресурсы: потребность в нормативном закреплении дефиниции

2.2.3. Техногенные минеральные ресурсы в структуре запасов полезных ископаемых.

2.3. Отходы горнодобывающего производства в уравнениях баланса вещества горной массы.

2.3.1. Возвратные и безвозвратные отходы добычи и переработки полезных ископаемых.

2.3.2. Разновидности накапливаемых отходов как объектов

управления.

88

2.4. Отходы недропользования и техногенные минеральные объекты.....

2.4.1. Отходы недропользования горнодобывающей промышленности...

2.4.2. Классы опасности горнопромышленных отходов и Федеральный классификационный каталог отходов.

2.4.3. Обобщенная классификация горнопромышленных отходов.........

2.4.4. Типология техногенных минеральных объектов......................

Выводы по главе 2

3. ПЕРЕВОД СИСТЕМЫ ГОСУДАРСТВЕННОГО ЭКОЛОГИЧЕСКОГО РЕГУЛИРОВАНИЯ НА МЕХАНИЗМ НАИЛУЧШИХ ДОСТУПНЫХ ТЕХНОЛОГИЙ: ОСОБЕННОСТИ ДЛЯ ПРЕДПРИЯТИЙ ГОРНОДОБЫВАЮЩЕЙ ПРОМЫШЛЕННОСТИ.....

3.1. Законодательная база применения механизма наилучших доступных технологий для борьбы с промышленными загрязнениями в Европейском союзе.

3.1.1. Комплексный подход к защите окружающей среды от промышленных загрязнений на основе наилучших доступных технологий в странах Европейского союза.....

3.1.2. Развитие базового законодательства об отходах и промышленных эмиссиях в Европейском союзе 
3.1.3. Регламентация содержания справочных документов по наилучшим доступным технологиям и определение экологических показателей для идентификации наилучших доступных технологий...... 3.1.4. Особенности регулирования обращения с отходами горнодобывающей промышленности в странах Европейского союза...... 3.2. Новая экологическая стратегия и переход на европейскую модель регулирования

3.2.1. Направления реформирования системы государственного экологического регулирования и обращения с отходами................. 3.2.2. Новации экологического регулирования и этапы перехода на механизм наилучших доступных технологий

3.2.3. Государственное экономическое стимулирование внедрения наилучших доступных технологий.

3.3. Технологическое нормирование в механизме наилучших доступных технологий

3.3.1. Категорирование и государственный учет объектов негативного воздействия на окружающую среду.

3.3.2. Система технологического нормирования и порядок расчета технологических нормативов....

3.3.3. Технологические показатели наилучших доступных технологий для объектов негативного воздействия на окружающую среду горнодобывающих предприятий

3.4. Информационно-технические справочники по наилучшим доступным технологиям как источники информации для предприятий с объектами первой категории

3.4.1. Информационно-технические справочники по наилучшим доступным технологиям и проблема измерения технологических показателей

3.4.2. Разработка и актуализация информационно-технических справочников по наилучшим доступным технологиям.

3.4.3. Анализ информационно-технических справочников по наилучшим доступным технологиям в области добычи твердых полезных ископаемых.

3.5. Комплексные экологические разрешения и декларации в системе экологического регулирования объектов первой и второй категорий

3.5.1. Нормативная правовая база комплексных экологических разрешений и деклараций о воздействии на окружающую среду. 3.5.2. Содержание заявки на получение комплексного экологического разрешения и декларации об объектах негативного воздействия на окружающую среду... 
4. МЕТОДОЛОГИЧЕСКИЕ АСПЕКТЫ ОБОСНОВАНИЯ И ОЦЕНКИ ЭКОНОМИЧЕСКОЙ ЭФФЕКТИВНОСТИ КОМПЛЕКСНОГО ИСПОЛЬЗОВАНИЯ ТЕХНОГЕННЫХ МИНЕРАЛЬНО-СЫРЬЕВЫХ РЕСУРСОВ

4.1. Методологические подходы к оценке экономической эффективности комплексного использования техногенного минерального сырья.

4.1.1. Проблема комплексного недропользования и оценки экономической эффективности переработки многокомпонентного минерального сырья.

4.1.2. Структурный анализ экономических факторов производственных моделей переработки многокомпонентного минерального сырья.......... 4.1.3. Методика оценки экономической эффективности извлечения компонентов и комплексного использования техногенного минерального сырья.

4.2. Экономический анализ проблемы установления цены на отходы недропользования как вторичное многокомпонентное сырье............. 4.2.1. Сложности ценообразования на отходы в комплексных производствах минерального сырья. 4.2.2. Проблема согласования цен на товарные концентраты из многокомпонентного техногенного сырья. .... 4.2.3. Принципы ценообразования и оценки экономической эффективности утилизации отходов добычи и переработки рудного сырья.

4.3. Методические подходы к покомпонентному обособлению прямых затрат при комбинированной переработке многокомпонентного минерального сырья.

4.3.1. Подходы к покомпонентному разделению прямых и косвенных затрат при комплексном использовании минерального сырья.............. 4.3.2. Диагностика прямых покомпонентных затрат при технологических операциях комплексной переработки минерального сырья

4.3.3. Необходимость дифференцированного учета затрат по отдельным процессам и операциям переработки многокомпонентного сырья

4.4. Экономическое обоснование методики расчета параметров кондиций для оконтуривания и подсчета промышленных запасов многокомпонентного природного и техногенного сырья. 4.4.1. Недостатки существующих подходов к оценке попутных компонентов многокомпонентного сырья при обосновании кондиций

4.4.2. Критический анализ положений о попутных компонентах в нормативно-методических документах Государственной комиссии по запасам полезных ископаемых........................................ 4.4.3. Методика расчета предельных содержаний ценных компонентов в полиметаллических рудах для целей их комплексной

переработки. 
5. ОЦЕНКА ЭКОНОМИЧЕСКОЙ ЭФФЕКТИВНОСТИ ОСВОЕНИЯ РАЗВЕДАННЫХ ЗАПАСОВ ТЕХНОГЕННОГО МЕСТОРОЖДЕНИЯ НА ПРИМЕРЕ ОТКРЫТОГО АКЦИОНЕРНОГО ОБЩЕСТВА «КОВДОРСКИЙ ГОК» МУРМАНСКОЙ ОБЛАСТИ.

5.1. Обобщенные результаты изучения отходов обогащения первого поля хвостохранилища.

5.2. Характеристика второго поля хвостохранилища по результатам разведки.

5.3. Технологические исследования обогатимости отходов второго поля хвостохранилища.

5.4. Расчет параметров кондиций для условий техногенного месторождения в рамках второго поля хвостохранилища

5.5. Технико-экономический расчет эффективности промышленного освоения запасов отходов (хвостов) второго поля хвостохранилища открытого акционерного общества «Ковдорский ГОК».

Выводы по главе 5 


\section{СПИСОК ПРИНЯТЫХ СОКРАЩЕНИЙ}

\begin{tabular}{|c|c|}
\hline АБД & автоматизированная база данных \\
\hline АБОФ & апатитобадделеитовая обогатительная фабрика \\
\hline БДО & банк данных об отходах \\
\hline БК & бадделеитовый концентрат \\
\hline BMP & вторичные минеральные ресурсы \\
\hline $\mathrm{BPB}$ & временно разрешенные выбросы \\
\hline $\mathrm{BPC}$ & временно разрешенные сбросы \\
\hline ГБЗ & Государственный баланс запасов \\
\hline ГКЗ & Государственная комиссия по запасам полезных ископаемых \\
\hline ГКО & Государственный кадастр отходов \\
\hline ГПО & горнопромышленные отходы \\
\hline ГПП & горнопромышленные производства \\
\hline ГРОРО & Государственный реестр объектов размещения отходов \\
\hline ДВОС & декларация о воздействии на окружающую среду \\
\hline ИТС & информационно-технический справочник \\
\hline КИМС & комплексное использование минерального сырья \\
\hline КЭР & комплексное экологическое разрешение \\
\hline ЛБМ & Лондонская биржа металлов \\
\hline $\mathrm{MBC}$ & межведомственный совет \\
\hline MMC & мокрая магнитная сепарация \\
\hline МСБ & минерально-сырьевая база \\
\hline $\mathrm{MCK}$ & минерально-сырьевой комплекс \\
\hline MCP & минерально-сырьевые ресурсы \\
\hline МТП & малообъемная технологическая проба \\
\hline $\mathrm{HBOC}$ & негативное воздействие на окружающую среду \\
\hline НДС & нормативы допустимых сбросов \\
\hline НИОКР & научно-исследовательские и опытно-конструкторские работы \\
\hline НДПИ & налог на добычу полезных ископаемых \\
\hline НДТ & наилучшие доступные технологии \\
\hline НООЛР & нормативы образования отходов и лимиты на их размещение \\
\hline ОКВЭД & Общероссийский классификатор видов экономической деятельности \\
\hline $\mathrm{OHB}$ & объект негативного воздействия \\
\hline $\mathrm{OPO}$ & объект размещения отходов \\
\hline $\mathrm{OC}$ & окружающая среда \\
\hline $\mathrm{OTH}$ & объект технологического нормирования \\
\hline ОФ & обогатительная фабрика \\
\hline ПДВ & предельно допустимые выбросы \\
\hline ПДК & предельно допустимые концентрации \\
\hline ПНО ОЛР & проект нормативов образования отходов и лимитов их размещения \\
\hline ППЭЭ & программа повышения экологической эффективности \\
\hline ПФ & песковая фабрика \\
\hline ПЭК & производственный экологический контроль \\
\hline P3Э & редкоземельные элементы \\
\hline TK3 & территориальная комиссия по запасам \\
\hline $\mathrm{TKO}$ & твердые коммунальные отходы \\
\hline $\mathrm{TKC}$ & технический комитет по стандартизации \\
\hline
\end{tabular}


TM техногенное месторождение

TMO техногенный минеральный объект

TMC техногенное минеральное сырье

TMP техногенные минеральные ресурсы

ТП технологические показатели

ТПИ твердые полезные ископаемые

ТРГ техническая рабочая группа

ТЭО технико-экономическое обоснование

ФККО Федеральный классификационный каталог отходов

ФОИВ федеральные органы исполнительной власти

ФЦП федеральная целевая программа

BAT Best Available Techniques (наилучшие доступные технологии)

BATIS Best Available Techniques Information System (Информационная система по НДТ)

BRIF Best Available Techniques Reference Document (справочный документ по НДТ)

MTWR Management of Tailings and Waste-Rock (обращение с хвостами обогащения и пустыми породами)

MWEI Management of Waste from Extractive Industries

(обращение с отходами добывающих отраслей промышленности) 


\section{ВВЕДЕНИЕ}

Ратифицированная Российской Федерацией Базельская конвенция о контроле за трансграничной перевозкой опасных отходов и их удалением [165] обязывает принимать надлежащие меры по обеспечению минимума образования отходов на территории страны с учетом социальных, технических и экономических аспектов, что требует не только решения проблемы утилизации накапливаемых отходов горного производства, но и технологической модернизации действующих производств.

Тему рационального использования ГПО как техногенных ресурсов нельзя назвать новой. Вопросы рационального недропользования, так или иначе затрагивающие отходы добычи и обогащения, исследовались не одним поколением российских (а ранее советских) ученых. Особенность авторского подхода к вопросу состоит в том, что ГПО в монографии рассматриваются в аспекте их двойственной природы: как вторичные минеральные ресурсы и как объекты негативного воздействия в условиях экологизации промышленных производств.

Обращение к проблеме рационального использования вторичных минеральных ресурсов объясняется несколькими причинами. Во-первых, переходом на экологическое регулирование, основанное на использовании НДТ. Новая система регулирования экологически опасных производств изменяет институциональную среду управления отходами производства и потребления, охватывая деятельность горнопромышленных предприятий и обращение с отходами этой деятельности.

Вторая причина связана с нарастанием горно-геологических и других проблем, характерных для горнодобывающего сектора экономики. Ухудшение качества природного минерального сырья и условий добычи полезных ископаемых, исчерпание разрабатываемых месторождений ведет к тому, что качество природных минеральных ресурсов становится сравнимым с качеством накопленного техногенного сырья. В результате увеличивается удельная составляющая отходов в добываемом сырье и создаются условия для неизбежного перехода на новый уровень кондиций.

Третья причина в том, что по-прежнему не решается проблема комплексного использования горнорудного сырья. Большинство рудных полезных ископаемых имеют поликомпонентный состав, в то время как месторождения разрабатываются, как правило, по моносырью. Недропользователи добывают основное полезное ископаемое, а попутные полезные ископаемые и ценные компоненты уходят в отходы добычи и первичной переработки. $\mathrm{B}$ итоге продолжается плохо контролируемое накопление отходов, темпы накопления имеют тенденцию к возрастанию, несмотря на прилагаемые в последние годы усилия по увеличению использования (утилизации) отходов добычи и связанных с ней перерабатывающих производств.

В настоящее время внимание общества и органов государственного управления сфокусировано на проблемах, связанных с отходами потребления, в первую очередь коммунальными. На фоне острых дискуссий проблема перевода на новое экологическое регулирование горнопромышленных производств и 
обращение с ГПО отошли в тень. Но от этого проблема не становится менее острой для горнодобывающих и перерабатывающих производств, региональных природных экосистем и местных сообществ.

На глобальном уровне экологический фактор в контексте социальной ответственности горного бизнеса постепенно меняет свою роль в системе корпоративных интересов и ценностей. По мнению аналитиков Deloitte ${ }^{1}$, для современных горнодобывающих компаний стратегическим приоритетом должно стать технологическое развитие. Компаниям рекомендуется четко сформулировать свои ценности и разработать дифференцированные бизнесмодели, обеспечивающие создание этих ценностей. Одна из тенденций усиление внимания к корпоративной социальной ответственности. В отличие от прошлых лет, акцент переносится на обеспечение взаимных выгод компаний и местных сообществ. Ведущие горнодобывающие компании рассматривают экологические расходы не как цену, которую надо платить за соответствие нормативным требованиям, а, скорее, как способ получения долгосрочных конкурентных преимуществ.

В Российской Федерации в последние годы принято несколько основополагающих документов, которые определили политику и долгосрочную стратегию в области экологии и обращения с отходами. В 2012 г. утверждены Основы государственной политики в области экологического развития Российской Федерации на период до 2030 года, в которых основными способами борьбы с накоплением отходов были названы предотвращение и сокращение их образования, вовлечение отходов в хозяйственный оборот, а также применение малоотходных и ресурсосберегающих технологий.

В 2017 г. принята Стратегия экологической безопасности РФ на период до 2025 года, в которой способами достижения необходимых целей названы стимулирование внедрения НДТ, создание современных объектов размещения отходов, увеличение их использования за счет субсидирования, предоставления налоговых и тарифных льгот, а также внедрение комплексных экологических разрешений для экологически опасных производств. При этом проблемной составляющей обращения с отходами названо их обезвреживание и использование в качестве вторичного сырья.

Спустя год, в 2018 г., была принята Стратегия развития промышленности по обработке, утилизации и обезвреживанию отходов производства и потребления на период до 2030 года. В документе зафиксировано неудовлетворительное положение дел с переработкой отходов и вовлечением их в хозяйственный оборот. Существенной причиной этого названа недостаточно эффективная государственная политика в сфере обращения с отходами, а общим сдерживающим фактором - несовершенство нормативной правовой базы. Результатом реализации Стратегии должно стать создание отрасли по обработке, утилизации и обезвреживанию отходов для максимального вовлечения отходов в хозяйственный оборот, а также создание соответствующей отечественной технологической и машиностроительной базы,

1 Тенденции развития - 2019. 10 ключевых факторов, оказывающих влияние на будущее горнодобывающего сектора. С. 29-32 // Deloitte: сайт. URL: https://www2.deloitte.com/ru/ru/pages/energy-and-resources/articles/tracking-the-trends.html (дата обращения: 15.10.2019). 
которая обеспечит выпуск современной техники, машин и оборудования для обработки, утилизации и обезвреживания отходов.

В 2018 г. утвержден паспорт национального проекта «Экология», включающего одиннадцать шестилетних федеральных проектов, один из которых - «Внедрение наилучших доступных технологий». Задачей данного проекта является применение всеми объектами, оказывающими значительное НВОС, системы экологического регулирования, основанной на использовании НДТ. Проект предусматривает финансирование в объеме 2,4 трлн руб., из которых 1,12 \% - бюджетные средства, остальные 98,88 \% - внебюджетные.

На фоне активного развития экологического законодательства законодательство о недрах, вышедшее «из недр» советской системы управления горнопромышленным комплексом, периодически претерпевает изменения по отдельным вопросам, затрагивая отходы добычи и переработки лишь в части их названия. Несмотря на существующие в отношении этих отходов противоречия между двумя отраслями права - экологическим и горным - проблема их устранения не находит своего решения, препятствуя вовлечению вторичных минеральных ресурсов в хозяйственный оборот.

Развитые страны мира достаточно давно пришли к пониманию необходимости концентрации на национальном уровне ответственности за управление отходами производства и потребления. В нашей стране по-прежнему отсутствует единая система управления отходами недропользования. Российское законодательство о недрах предписывает считать использование отходов горнодобывающих производств частью процесса добычи полезных ископаемых, что приравнивает отходы добычи и переработки к природным ресурсам недр. Этот аспект не учитывает особенности вторичного минерального сырья как потенциального ресурса и является демотивирующим фактором в отношении переработки лежалых отходов и техногенных месторождений. В результате административного уравнивания порядка получения права пользования недрами в отношении первичных и вторичных минеральных ресурсов последние становятся и будут оставаться инвестиционно непривлекательными для недропользователей и инвесторов, а для заинтересованного в переработке техногенного сырья малого (инновационного) горного бизнеса барьеры входа в отрасль оказываются практически непреодолимыми без поддержки государства.

Не последнюю роль в создании барьеров на пути к рациональному использованию накопившегося и продолжающего накапливаться ТМС играет отсутствие нормативно закрепленных понятий «вторичные минеральные ресурсы», «техногенное месторождение» и других. Современное горнорудное производство, как и ранее, нуждается в скорейшем переходе к инновационному, высокотехнологичному развитию. Импульс такому развитию может дать внедрение концепции НДТ, которая объединяет технологический, экологический и экономический аспекты используемых методов и оборудования в практически реализуемые комплексы с известной эффективностью. Механизм НДТ, включающий технологическое нормирование и комплексные экологические разрешения, при его правильном применении со стороны государства способен действовать в направлении снижения минимального уровня качества минерального сырья, при котором его промышленная переработка будет оставаться экономически целесообразной. Тот же эффект 
может быть получен в отношении повышения комплексности использования природного или техногенного минерального сырья. Вышеперечисленные и другие вопросы нашли отражение в данной работе.

В написании монографии приняли участие: доктор экономических наук, профессор В. А. Кныш (введение, главы 1, 2, 3, заключение), доктор экономических наук, профессор Ф. Д. Ларичкин (введение, главы 4, 5, заключение), кандидат экономических наук, доцент М. А. Невская (глава 1, разделы 1.1, 1.2, главы 2, 3), доктор экономических наук, доцент С. В. Федосеев (глава 3), доктор экономических наук Т. А. Блошенко (глава 1, раздел 1.3), кандидат экономических наук В. Д. Новосельцева (глава 4, разделы 4.2, 4.4, глава 5), кандидат технических наук И. В. Мелик-Гайказов (глава 5), В. Н. Переин (главы 4, 5), научный сотрудник Л. И. Гончарова (главы 4, 5, раздел 5.1), аспирант А. А. Гилярова (глава 1, раздел 1.4). Общее редактирование монографии - профессор В. А. Кныш.

Монография базируется на научных результатах выполнения государственного задания Федерального исследовательского центра «Кольский научный центр Российской академии наук» № 0226-2019-0024 ИЭП. В разделах 1.1 и 1.2 представлены результаты исследований, выполненных при финансовой поддержке РФФИ и Министерства культуры, образования, науки и спорта Монголии в рамках научного проекта № 19-510-44013/19. 


\section{1. ПРОБЛЕМА ИСПОЛЬЗОВАНИЯ НАКОПЛЕННОГО РЕСУРСНОГО ПОТЕНЦИАЛА ОТХОДОВ ГОРНОГО ПРОИЗВОДСТВА В УСЛОВИЯХ ЭКОЛОГИЗАЦИИ ПРОМЫШЛЕННОСТИ}

\section{1. Анализ тенденций в сфере образования и использования отходов горного производства}

\subsection{1. Рациональное использование ресурсов недр-один из принципов устойчивого развития}

Закон РФ «О недрах» рассматривает рациональное использование недр в неразрывной связи с их охраной. Ключевым требованием является обеспечение наиболее полного извлечения из недр запасов основных и совместно с ними залегающих полезных ископаемых и попутных компонентов. Принцип рационального использования и охраны недр в интересах нынешнего и будущих поколений является одним из основных наиболее важных принципов устойчивого развития.

В соответствии с ГОСТ Р 57677-2017 рациональныци является такое использование недр, которое предполагает, наряду с полным и комплексным извлечением содержащихся в недрах полезных ископаемых, «максимально эффективное использование иных ресурсов недр посредством применения наилучших современных технологий для разработки или сохранения нерентабельных к отработке месторождений при возможности их последующей эксплуатации с обеспечением минимизации вредного воздействия на другие компоненты природной среды».

А. И. Цуранова в своей диссертации показала, что в правовом отношении категории «рациональное использование недр» и «рациональное использование природных ресурсов» являются эквивалентными и могут использоваться как синонимы [142]. Разновидностью природных ресурсов являются минеральные ресурсы недр.

Таким образом, все аспекты «рациональности» в отношении использования недр переносятся на «рациональность» использования ресурсов недр, минеральных ресурсов. В этой связи необходимо отметить следующее: 1) законодательство о недрах (недропользовании) не содержит нормативно закрепленных критериев рациональности использования ресурсов недр, учитывающих особенности их пользования для различных целей, что, по мнению специалистов в области горного права, снижает эффективность правового регулирования отношений, возникающих в связи с обеспечением рационального использования извлекаемых из недр полезных ископаемых [143]; 2) закон РФ «О недрах» напрямую не требует рационального использования отходов добычи и связанных с ней перерабатывающих производств (отходов недропользования) ${ }^{2}$, однако указывает, что при первичной переработке

\footnotetext{
2 Предложение заменить термин «отходы добычи и связанных с ней перерабатывающих производств» термином «отходы недропользования» содержит правительственный законопроект № 664487-7 от 13 марта 2019 г., вынесенный на рассмотрение
} 
получаемого из недр минерального сырья пользователи недр должны обеспечить «наиболее полное использование продуктов и отходов переработки (шламов, пылей, сточных вод и других); складирование, учет и сохранение временно не используемых продуктов и отходов производства, содержащих полезные компоненты» (Закон РФ «О недрах» ст. 23.3 «Первичная переработка минерального сырья пользователями недр») $)^{3}$; 3) требование рациональности использования в равной степени относится как к первичным, так и к ВМР, обладающим достаточным потенциалом для промышленного использования на определенном уровне технологического развития горнодобывающих производств; при этом понятие «вторичные минеральные ресурсы» требует обоснования и соотнесения с понятием «отходы добычи и переработки (обогащения) полезных ископаемых»; 4) современная трактовка рациональности использования ресурсов недр, приведенная в ГОСТ Р 57677-2017, опирается на мировой, в частности европейский, опыт борьбы с промышленными эмиссиями и акцентирует внимание на экологичности технологий разработки месторождений и сохранении нерентабельных к отработке месторождений при возможности их последующей эксплуатации с обеспечением минимизации вредного воздействия на другие компоненты природной среды; экологичность горнодобывающих и связанных с ними обрабатывающих производств на основе внедрения НДТ становится фактором конкурентоспособности и вектором устойчивого развития компаний минерально-сырьевого сектора на глобальном уровне.

Традиционно использование отходов горного производства рассматривается как фактор, обеспечивающий расширение минерально-сырьевой базы, преодоление дефицита природного минерального сырья, экономию средств на размещение отходов, снижение потребности в инвестициях для освоения новых месторождений, предотвращение и снижение ущерба ОС, получение дополнительных социальных эффектов. Однако не все отходы добычи и переработки полезных ископаемых могут рассматриваться как минеральные ресурсы, пригодные для промышленного освоения. Этот аспект будет рассмотрен нами отдельно.

\subsection{2. Ресурсный потенциал и опыт переработки горнопромышленных отходов}

Существуют разнообразные источники, в которых приводятся оценочные данные, характеризующие ресурсный потенциал накопленных на территории России ГПО. Государственным балансом запасов учтены различные полезные ископаемые техногенного генезиса. Среди них преобладают золотосодержащие техногенные объекты (свыше ста объектов). Кроме того, учтено восемнадцать оловянных, семнадцать железорудных, десять мусковитных, семь медных и шесть вольфрамовых TM. От одного до четырех техногенных объектов учтено по платиноидам, алмазам, молибдену, хрому, мышьяку, свинцу, цинку, цирконию, бокситам, фосфоритам и апатитам, а также редкоземельным и рассеянным элементам [18].

Государственной Думы. На конец 2019 г. законопроект готовился к рассмотрению Государственной Думой во втором чтении.

3 Закон Российской Федерации «О недрах» (в ред. от 3 марта 1995 г., с изм. на 2 августа 2019 г.) // КонсультантПлюс: офиц. интернет-портал. URL: http:/www.consultant.ru/ document/cons_doc_LAW_343/(дата обращения: 10.12.2019). 
Общее количество железа в отвалах бедных и разубоженных руд, окисленных железистых кварцитов, металлургического шлака черной металлургии приближается к 200 млн т. По данным Госкомстата и других источников, только в отходах цветной металлургии России содержится (тыс. т): меди - 7790, свинца - 980, цинка - 9000, олова - 540, никеля - 2480, вольфрама - 129, молибдена - 114, лития 97 и др. Основные объемы цветных металлов сосредоточены в отвалах некондиционных руд и хвостохранилищах обогатительных фабрик [124].

Отходы добычи и обогащения металлических руд и горно-химического сырья, отходы металлургического производства обладают значительным потенциалом для извлечения редкоземельных металлов. Например, источником получения рения может служить пыль обжига молибденовых концентратов; для получения селена и теллура пригодны отходы переработки сульфидных медных руд; кадмия, таллия, индия - полиметаллических руд, галлия - отходы переработки бокситов и нефелинов [3].

Как отмечает академик РАН Ю.Н. Малышев, содержание полезных компонентов в отходах горно-обогатительного и металлургического комплексов нередко превышает их содержание в рудах, извлекаемых из недр и поступающих на обогащение. В особенности это относится к старым отвалам и хвостохранилищам, которые формировались в 1940-1950-е гг., когда использовались примитивные технологии добычи и обогащения. На современном этапе при добыче теряется около $12 \%$ угля, $3 \%$ меди и $4 \%$ железа. При этом в процессе добычи одной тонны цветных металлов образуется не менее 100-150 т отходов, а при их переработке - более 50-60 т. В процессе добычи одной тонны редких, драгоценных и радиоактивных металлов образуется до 5-10 тыс. т отходов, а при их переработке - от 10 до 100 тыс. т4.

Наиболее объемным видом металлургических отходов являются отвальные шлаки. В никелевой подотрасли количество заскладированных шлаков в конце прошлого столетия оценивалось в 300 млн т. Только за время работы комбинатов «Североникель» и «Печенганикель» Кольской ГМК шлаков накопилось более 100 млн т, а содержание в них цветных металлов оценивается на сумму более 10 млрд долл. США. В хозяйственный оборот вовлекается лишь небольшая их часть, в основном в качестве закладочного материала и при отсыпке дорог. Складирование шлаков приводит к постепенному вымыванию из них меди, никеля и кобальта, что вызывает загрязнение природных вод вокруг медно-никелевого комбината тяжелыми металлами. Переработка 1 млн т отвальных шлаков в год позволила бы произвести на Кольском полуострове сырье для получения 100 тыс. т магния. Здесь имеется избыток электроэнергии и есть куда использовать отход производства магниевых комбинатов - хлор. В настоящее время Кольская ГМК широко использует данный реагент, но вынуждена завозить его из-за пределов Мурманской области [53].

В Мурманской области известно более 180 месторождений полезных ископаемых, развита горная промышленность, работают комбинаты,

\footnotetext{
${ }^{4}$ Малышев Ю. Н. Развитие горнопромышленного комплекса в условиях обострения конкуренции на мировых рынках минеральных ресурсов / НП «Горнопромышленники России», 2013 // Горнопромышленный портал России. URL: http://www.miningexpo.ru/ news/24051?showmonth=11 (дата обращения: 12.10.2019).
} 
эксплуатирующие медно-никелевые, апатитонефелиновые, апатитомагнетитовые, железные, слюдяные руды и руды редких металлов [28]. Выход конечного продукта из руды, добытой предприятиями Кольского горнопромышленного комплекса, в зависимости от типа сырья изменяется от 1 до $40 \%$, а остальные материалы в виде породы от вскрышных и проходческих работ, хвостов обогащения, шлаков и кеков, а также зол ТЭС размещены в хвостохранилищах и отвалах, занимающих сотни квадратных километров. При этом в техногенных отходах содержатся попутные полезные компоненты, на долю которых в объемном выражении приходится до 50$60 \%$ материала, а в стоимостном - 25-30\% [95].

По некоторым оценкам только отходы обогащения горнодобывающих предприятий Мурманской области содержат запасы цветных металлов $(\mathrm{Ni}, \mathrm{Cu}$, Со) в количестве 1248 тыс. т, редких металлов (лопарит) 100,8 тыс. т; железа 31 млн т, циркония 0,7 тыс. т, апатита $\left(\mathrm{P}_{2} \mathrm{O}_{5}\right) 38,5$ и нефелина $\left(\mathrm{Al}_{2} \mathrm{O}_{3}\right) 189,8$ млн т . Использование техногенных отходов в Мурманской области не превышает $5 \%$ от общего объема, но опыт Ковдорского ГОКа (2010-2014 гг.) показывает, что при благоприятной рыночной конъюнктуре преимущества техногенного сырья (относительно небольшие затраты на добычу и переработку) делают его использование весьма эффективным и прибыльным [76].

Примером высокой ценности ГПО могут служить техногенные отходы медной подотрасли Урала, в которых среднее содержание меди $(0,34-0,37 \%)$ в отвалах некондиционных руд, хвостах обогащения и шлаках медных заводов близко к кондиционным $(0,35-0,5 \%)$. Определенная их часть вполне конкурентоспособна по сравнению с коренными рудами. В медных рудах Урала помимо меди содержится еще пятнадцать ценных компонентов $(\mathrm{Zn}, \mathrm{Pb}, \mathrm{S}, \mathrm{Au}$, $\mathrm{Ag}, \mathrm{Bi}, \mathrm{Cd}, \mathrm{Ge}, \mathrm{Re}, \mathrm{Sn}, \mathrm{Se}, \mathrm{Te}, \mathrm{Ni}, \mathrm{In}, \mathrm{Sb})$. Кроме того, в шлаках содержится до 30 и более \% железа. В регионе еще к 2003 г. было накоплено 220 млн т хвостов обогащения, складировано свыше 110 млн т медных шлаков, содержащих в среднем 0,37 \% меди, 2,29 \% цинка и 0,98 \% серы, а также более 7 т золота и 150 т серебра, 23 т висмута и 8 тыс. т кадмия [33]. Аналогичные результаты анализа состава отвалов некондиционных руд характерны и для многих других горнопромышленных районов и типов рудных месторождений.

В России имеется опыт переработки ГПО Урала в рамках ФЦП «Переработка техногенных образований Свердловской области», в соответствии с которой в 19962001 гг. было выполнено работ на сумму 1318, 4 млн руб. [172]. Только в 2001 г. на территории Свердловской области было переработано 11,6 млн т техногенных образований, в том числе: отходов металлургического комплекса - 5289,3 тыс. т, отходов добычи и обогащения - 6353,6 тыс. т и 48,5 т прочих отходов. Из отходов техногенных образований было изготовлено продукции на сумму боле 2 млрд руб., среди которой (тыс. т): медного концентрата - 13,3, черновой меди - 14,1, рафинированной меди - 4,9, металлопродукта - 487,0, железа - 57,3, феррохрома - 2,4, асбеста - 37,9, строительного щебня различных фракций - 4,3, строительных песков - 456,3, сульфата алюминия - 32,4. Также были получены глиноземный полупродукт различных марок, восстановленные ванадиевые катализаторы, пятиокись ванадия [33].

\footnotetext{
${ }^{5}$ Бусырев В. М., Чуркин О. Е. Оценка стоимости запасов и эффективности освоения техногенных месторождений // ГИАБ. 2016. № 6. URL: http://www.giabonline.ru/files/Data/2016/6/106_114_6_2016.pdf (дата обращения: 24.08.2019).
} 
Отходы горнопромышленных предприятий являются важным источником сырья для стройиндустрии. По имеющимся данным, около 40 млрд т ГПО потенциально пригодны для производства строительных материалов (не менее $30 \%$ вскрышных пород и хвостов обогащения, практически все металлургические и топливные шлаки) [124]. Для производства щебня, цемента, керамических стеновых материалов пригодна большая часть вскрышных пород железорудных месторождений.

По своим технологическим параметрам и физико-механическим свойствам ГПО не уступают природному строительному сырью, а объемы техногенного сырья многократно превышают потребности стройиндустрии. Однако их активному вовлечению в хозяйственный оборот препятствуют низкий спрос в районах расположения техногенных образований и другие факторы, в частности высокие транспортные издержки для удовлетворения потребностей в отдаленных районах.

Накопленные на территории России ГПО вполне обоснованно являются резервом пополнения МСБ ТПИ, но, несмотря на огромный ресурсный потенциал и то, что «резервы полезных компонентов в накопленных отходах равноценны открытию многих новых месторождений» [125], в нашей стране они традиционно используются нерационально, в основном как сырье для стройиндустрии.

Изучение опыта зарубежных стран показывает, что там степень вовлечения отходов в хозяйственный оборот гораздо выше. Большинство развитых стран давно практикует политику сбережения своих минеральных ресурсов, интенсивно утилизируя отходы производства и разрабатывая технологии их переработки. Из ГПО с помощью нетрадиционных технологий (различных видов выщелачивания) получают более 40 \% годового объема меди, 35 \% золота и значительную долю других металлов. Например, в США еще в 1993 г. доля вторичного сырья в производстве цветных металлов составляла (\%): по меди - 55, вольфраму — 28, никелю -25. Подобная тенденция использования вторичных ресурсов наблюдается в Канаде, Великобритании, ЮАР, Испании и других странах [33].

В России утилизации подвергается 20-25 \% ежегодно образуемых ГПО, в то время как в США и странах Западной Европы они используются на 85$90 \%$; этому способствуют дефицит и высокая стоимость земель, система санкций за загрязнение ОС, отлаженный контроль за использованием земель и недр с применением космических средств наблюдения, а также система поощрительных платежей (за внедрение мало- и безотходных технологий, вторичное использование отходов) [72].

В Германии степень утилизации отходов в отдельных отраслях достигает 90-98 \% из-за существования разнообразных привилегий для их переработчиков, включая льготные кредиты предприятиям и освобождение их от налогов и пошлин. Поэтому главной проблемой низкой степени утилизации отходов в нашей стране в первую очередь является отсутствие должных экономических стимулов. Опыт других стран показывает, что эффективная экологическая и экономическая система природопользования может быть создана только при более активном участии государства [53].

Таким образом, целесообразность вовлечения отходов производства и потребления в хозяйственный оборот в качестве вторичного сырья доказана 
многолетней практикой многих стран мира. Например, в сырьевом балансе США и Японии доля отходов составляет до $26 \%$, у большинства экономически развитых стран этот показатель колеблется в пределах 16-20\%, в СССР он составлял $15 \%$, в современной России - около $10 \%{ }^{6}$.

Заслуживает пристального внимания развитие законодательства, практические достижения и положительный опыт обращения с отходами в странах Европейского союза, где осуществляются комплексные меры по стимулированию трех взаимосвязанных направлений: 1) предотвращение или сокращение образования отходов и снижение их опасных свойств; 2) вовлечение отходов в хозяйственный оборот; 3) сокращение отходов, направляемых на окончательное захоронение. В России низкий уровень использования ГПО в качестве ВМР обусловлен не отсутствием технологических разработок, а несовершенством организационно-экономического механизма обращения с ними, неразвитостью методов стоимостной оценки отходов и методологии оценки экономической эффективности их комплексной утилизации, отсутствием у предприятий реальных экономических стимулов для их переработки [31].

\subsection{3. Динамика образования, использования и накопления горнопромыщленных отходов: экологический фактор}

Отходы горно-обогатительного и горно-металлургического производств являются серьезным источником загрязнения ОС. Основными отходообразующими отраслями в России являются: угольная промышленность (55-57 \% промышленных отходов, включая добычу, обогащение и агломерацию угля); черная металлургия (10$12 \%$, включая добычу, обогащение и переработку железных руд); цветная металлургия (14-16\%, добыча урановой и ториевой руд — около $5 \%$ ); добыча прочих полезных ископаемых - 8-10\% [22].

Известно, что ресурсоемкость единицы ВВП в России в 2-3 раза выше, чем в странах с развитой рыночной экономикой. Это означает, что для производства одной тонны продукции в нашей стране вовлекается в 2-3 раза больше природных ресурсов при пропорциональном увеличении образования отходов [77].

Образование отходов на душу населения в странах ЕС составляет в среднем 6 т (160 кг на единицу ВВП на душу населения) ${ }^{7}$, а в России - 34,5 т (3810 кг на единицу ВВП на душу населения, 2015 г.). Для горнорудного предприятия средней производительности требуется земельный отвод площадью 2-3 тыс. га. С учетом влияния ветров и миграции вод площадь, подвергаемая влиянию, увеличивается в 1015 раз [37]. Например, в Восточном Донбассе породными отвалами занято более 1,3 тыс. га земель, а общая площадь земель, нарушенных угледобычей и обогащением, превышает 7 тыс. га [41].

\footnotetext{
${ }^{6}$ Ларичкин Ф. Д., Переин В. Н., Гончарова Л. И. Проблемы рационального обращения с горнопромышленными отходами // Проблемы рационального использования природного и техногенного сырья Баренц-региона в технологии строительных и технических материалов // Материалы V ВНК с международным участием. Апатиты, 2013 г. // Гелион: сайт. URL: https://helion-ltd.ru/mountain-industrial-wastes/ (дата обращения: 10.11.2019).

${ }^{7}$ Review of Waste Policy and Legislation, accessed 6 March 2014. URL: http://ec.europa.eu/ environment/waste/target_review.htm (дата обращения: 11.04.2019).
} 
Общая площадь земель, занятых отходами, превышает 2000 тыс. км², из них более 0,6 тыс. км² - шламонакопители и хвостохранилища, более 1 тыс. км $^{2}$ - отвалы, терриконы, золо- и шлакоотвалы. Ежегодно площадь отчуждаемых земель увеличивается не менее чем на 85-90 км² $[33,140]$. В результате длительного открытого хранения при атмосферном воздействии полезные компоненты «элиминируют в ОС, превращаясь в поллютанты», увеличивая риск загрязнения поверхностных и подземных вод, уничтожения растительного покрова, изменения структуры ландшафтов [113].

Особенно остро экологические проблемы ГПО проявляются в северовосточных и арктических регионах, где сосредоточены основные запасы минеральносырьевых ресурсов, а хозяйственная деятельность ориентирована на сырьевой сектор в экстремальных природных условиях $[136,156]$. Примером является экологическое состояние районов Кольского полуострова, где сконцентрированы крупные горнодобывающие и горно-металлургические производства Северо-Запада, которое оценивается как критическое. Здесь накоплено более 6 млрд т твердых отходов и ежегодно производится около 200 млн т [115].

Образование и накопление отходов горного производства не являются проблемой отдельных горных производств, о ее национальном масштабе свидетельствуют данные официальной статистики (табл. 1.1). На долю промышленных отходов приходится более $96 \%$ всех отходов производства и потребления, учитываемых национальной статистикой. Более $90 \%$ суммарного количества образующихся за год отходов производства и потребления всех классов опасности относятся к отходам, образующимся при добыче полезных ископаемых, из которых более 60 \% связаны с добычей топливно-энергетических ресурсов. Доля отходов обрабатывающих производств составляет около 5 \% от всех образующихся, из которых более половины - отходы металлургии и производства готовых металлических изделий. Среди отраслей промышленности доминирующими по образованию и накоплению отходов являются угольная отрасль, а также черная и цветная металлургия. Показатели образования, использования и накопления отходов горной добычи, полученные на основе обработки статистической информации, представлены в табл. 1.2.

Таким образом, более $50 \%$ ежегодно производимых отходов производства и потребления, связанных с деятельностью по добыче полезных ископаемых, накапливается в ОС, при этом основная их масса (более 60\%) приходится на добычу топливно-энергетических полезных ископаемых. Если в 2005 г. в среднем на каждую тонну добытых топливно-энергетических ресурсов приходилось около 2 т извлеченных отходов, то в 2009 г. уже более 2,5 т, в 2015 г. - более 3 т, а в 2017 г. - более 4 т. Аналогичные показатели по накоплению отходов составили соответственно 0,$87 ; 1,21 ; 1,57$ и 1,8 т на тонну добытых топливно-энергетических ресурсов. 
Структура отходов производства и потребления в динамике их образования, 2014-2018 гг.

\begin{tabular}{|c|c|c|c|c|c|c|c|c|c|c|}
\hline \multirow[t]{2}{*}{ Показатель } & $\begin{array}{c}2014 \\
\Gamma .\end{array}$ & $\begin{array}{c}2015 \\
\Gamma .\end{array}$ & $\begin{array}{c}2016^{*} \\
\Gamma .\end{array}$ & $\begin{array}{c}2017 \\
\Gamma .\end{array}$ & $\begin{array}{c}2018 \\
\Gamma .\end{array}$ & $\begin{array}{c}2014 \\
\Gamma .\end{array}$ & $\begin{array}{c}2015 \\
\Gamma .\end{array}$ & $\begin{array}{c}2016 \\
\Gamma .\end{array}$ & $\begin{array}{c}2017 \\
\Gamma .\end{array}$ & $\begin{array}{c}2018 \\
\Gamma .\end{array}$ \\
\hline & \multicolumn{5}{|c|}{ МЛН Т } & \multicolumn{5}{|c|}{$\%$} \\
\hline Образовано отходов, всего & 5168,3 & 5060,2 & 5441,3 & 6220,6 & 7266,0 & 100 & 100 & 100 & 100 & 100 \\
\hline $\begin{array}{l}\text { В том числе при добыче } \\
\text { полезных ископаемых }\end{array}$ & 4807,3 & 4653,0 & 4723,8 & 5786,1 & 6850,4 & 93,0 & 91,9 & 86,8 & 93,0 & 94,3 \\
\hline топливно-энергетических полезных ископаемых & 3187,5 & 3106,6 & 3385,7 & 3883,4 & 4825,4 & 66,3 & 66,7 & 62,2 & 71,7 & 67,1 \\
\hline $\begin{array}{l}\text { полезных ископаемых, кроме топливно- } \\
\text { энергетических }\end{array}$ & 1619,8 & 1546,4 & 1333,8 & 1898,5 & 2021,2 & 33,7 & 33,3 & 37,8 & 28,3 & 32,9 \\
\hline Обрабатывающие производства & 243,1 & 282,9 & 549,3 & 274,8 & 243,8 & 4,7 & 5,5 & 10,1 & 4,4 & 3,4 \\
\hline $\begin{array}{l}\text { В том числе металлургическое производство и } \\
\text { производство готовых металлических изделий }\end{array}$ & 168,3 & 215,0 & 194,1 & 154,1 & 137,1 & 69,2 & 75,9 & 35,4 & 56,1 & 56,2 \\
\hline
\end{tabular}

Примечание. Источник: составлено на основе данных таблицы «Образование отходов производства и потребления по видам экономической деятельности по Российской Федерации» // Федеральная служба государственной статистики: официал. сайт. URL: http://www.gks.ru/wps/wcm/connect/rosstat_main/rosstat/ru/statistics/environment/ (дата обращения: 15.07.2019).

* С 2016 г. в топливно-энергетические полезные ископаемые включается добыча угля, сырой нефти и природного газа (не учитывается добыча урана и горючего сланца). «Металлургическое производство» и «Производство готовых металлических изделий, кроме машин и оборудования» выделены в отдельные позиции. 
Данные об объемах промышленного производства, образовании и накоплении отходов, 2005-2018 гг.

\begin{tabular}{|c|c|c|c|c|c|c|c|c|c|c|c|c|c|c|}
\hline Показатель & 2005 г. & 2006 г. & 2007 г. & 2008 г. & 2009 г. & 2010 г. & 2011 г. & 2012 г. & 2013 г. & 2014 г. & 2015 г. & 2016 г. & 2017 г. & 2018 г. \\
\hline \multicolumn{15}{|c|}{ Образование отходов производства и потребления по видам экономической деятельности, млн т } \\
\hline Всего & 3035,5 & 3519,4 & 3899,3 & 3876,9 & 3505 & 3734,7 & 4303,3 & 5007,9 & 5152,8 & 5168,3 & 5060,2 & 5441,3 & 6220,6 & 7266,0 \\
\hline $\begin{array}{l}\text { В том числе при добыче } \\
\text { полезных ископаемых }\end{array}$ & 2506,2 & 2923,5 & 2785,2 & 3402,4 & 3066,5 & 3334,6 & 3818,7 & 4629,3 & 4701,2 & 4807,3 & 4653 & 4723,8 & 5786,1 & 6850,4 \\
\hline топливно-энергетических & 1498,6 & 1732,1 & 1636,3 & 2089,9 & 1984,9 & 2204,3 & 2527,8 & 3022,8 & 3010,5 & 3187,5 & 3106,6 & 3385,7 & 3883,4 & 4825,4 \\
\hline \multicolumn{15}{|c|}{ Использование и обезвреживание отходов по видам экономической деятельности, млн т } \\
\hline Всего & 1262,8 & 1395,8 & 2257,4 & 1960,7 & 1661,4 & 1738,1 & 1990,7 & 2348,1 & 2043,6 & 2357,2 & 2685,1 & 3243,7 & 3264,6 & 3818,4 \\
\hline $\begin{array}{l}\text { В том числе при добыче } \\
\text { полезных ископаемых }\end{array}$ & 1070,4 & 1144,5 & 1829,4 & 1723,6 & 1469,4 & 1562,2 & 1800,1 & 2125,9 & 1753,1 & 2165,7 & 2473,3 & 2885,6 & 3021,8 & 3585,2 \\
\hline топливно-энергетических & 833,1 & 918,9 & 1051,1 & 1320,3 & 1132,5 & 1206,2 & 1341,1 & 1589,3 & 1120,2 & 1433,3 & 1681,9 & 2309,7 & 2159,9 & 2549,4 \\
\hline \multicolumn{15}{|c|}{ Объем накопления отходов, млн $m$} \\
\hline Всего & 1772,7 & 2123,6 & 1641,9 & 1916,2 & 1843,6 & 1996,6 & 2312,6 & 2659,8 & 3109,2 & 2811,1 & 2375,1 & 2197,6 & 2956 & 3447,6 \\
\hline $\begin{array}{l}\text { В том числе при добыче } \\
\text { полезных ископаемых }\end{array}$ & 1435,8 & 1779 & 955,8 & 1678,8 & 1597,1 & 1772,4 & 2018,6 & 2503,4 & 2948,1 & 2641,6 & 2179,7 & 1838,2 & 2764,3 & 3265,2 \\
\hline топливно-энергетических & 665,5 & 813,2 & 585,2 & 769,6 & 852,4 & 998,1 & 1186,7 & 1433,5 & 1890,3 & 1754,2 & 1424,7 & 1076 & 1723,5 & 2276 \\
\hline \multicolumn{15}{|c|}{ Объемы добычи основных топливно-энергетических ископаемых, млн т } \\
\hline Уголь & 299 & 310 & 314 & 329 & 301 & 322 & 336 & 357 & 353 & 357 & 372 & 386 & 411 & Нд \\
\hline Нефть и газовый конденсат & 470 & 481 & 491 & 488 & 494 & 506 & 512 & 519 & 522 & 526 & 535 & 548 & 546 & Нд \\
\hline $\begin{array}{l}\text { Уголь, нефть, газовый конденсат, } \\
\text { всего }\end{array}$ & 769 & 791 & 805 & 817 & 795 & 828 & 848 & 876 & 873 & 883 & 907 & 934 & 957 & Нд \\
\hline
\end{tabular}

Примечание. Источник: Составлено на основе статистического бюллетеня «Основные показатели охраны окружающей среды». URL: http://www.gks.ru/.

* В объеме основных топливно-энергетических ресурсов не учитывался объем добычи природного газа. 
С 2016 г. вместо термина «использование и обезвреживание отходов производства и потребления» введен термин «утилизация и обезвреживание отходов производства и потребления». Сравнительный анализ объемов добычи полезных ископаемых в 2005 и 2017 гг., а также образованных в эти годы отходов показывает, что рост их образования и накопления по рассматриваемым видам деятельности значительно опережает рост объемов производства (табл. 1.3).

Таблица 1.3

Динамика образования, использования и накопления отходов производства и потребления

\begin{tabular}{|c|c|c|c|}
\hline Показатель & $\begin{array}{c}2005 \text { г., } \\
\text { млН т }\end{array}$ & $\begin{array}{c}2017 \text { г., } \\
\text { млн т }\end{array}$ & $\begin{array}{c}2017 / 2005 \text { гг., } \\
\%\end{array}$ \\
\hline 1 & 2 & 3 & 4 \\
\hline \multicolumn{4}{|c|}{$\begin{array}{c}\text { Образование отходов производства и потребления по видам экономической } \\
\text { деятельности, млн } m\end{array}$} \\
\hline $\begin{array}{r}\text { В том числе при добыче } \\
\text { полезных ископаемых }\end{array}$ & 2506,2 & 5786,1 & 230,9 \\
\hline топливно-энергетических & 1498,6 & 3883,4 & 259,1 \\
\hline $\begin{array}{l}\text { полезных ископаемых, кроме } \\
\text { топливно-энергетических }\end{array}$ & 1007,6 & 1898,5 & 188,4 \\
\hline $\begin{array}{l}\text { Металлургическое производство } \\
\text { и производство готовых } \\
\text { металлических изделий }\end{array}$ & 180,4 & 154,1 & 85,4 \\
\hline \multicolumn{4}{|c|}{$\begin{array}{c}\text { Использование (утилизаџия) и обезврежсивание отходов по видам экономической } \\
\text { деятельности, млн m }\end{array}$} \\
\hline \multicolumn{4}{|l|}{ В том числе при добыче } \\
\hline полезных ископаемых & 1070,4 & 3021,8 & 282,3 \\
\hline топливно-энергетических & 833,1 & 2159,9 & 259,3 \\
\hline $\begin{array}{l}\text { полезных ископаемых, кроме } \\
\text { топливно-энергетических }\end{array}$ & 237,3 & 860,6 & 362,7 \\
\hline $\begin{array}{l}\text { Металлургическое производство } \\
\text { и производство готовых } \\
\text { металлических изделий }\end{array}$ & 65,4 & 74,2 & 113,5 \\
\hline \multicolumn{4}{|c|}{ Накопление (размещение и захоронение отходов), млн $m$} \\
\hline \multicolumn{4}{|l|}{ В том числе при добыче } \\
\hline полезных ископаемых & 1435,8 & 2764,3 & 192,5 \\
\hline топливно-энергетических & 665,5 & 1723,5 & 258,9 \\
\hline $\begin{array}{l}\text { полезных ископаемых, кроме } \\
\text { топливно-энергетических }\end{array}$ & 770,3 & 1037,9 & 134,7 \\
\hline $\begin{array}{l}\text { Металлургическое производство } \\
\text { и производство готовых } \\
\text { металлических изделий }\end{array}$ & 115,0 & 79,9 & 69,5 \\
\hline
\end{tabular}


Окончание таблищы 1.3

\begin{tabular}{|l|c|c|}
\hline \multicolumn{1}{|c|}{ Рост объемов производства, \% } \\
\hline \multicolumn{3}{|c|}{} \\
\hline Добыча полезных ископаемых, всего & \multicolumn{3}{|c|}{$118,8^{*}$} \\
\hline $\begin{array}{l}\text { в том числе топливно- } \\
\text { энергетических }\end{array}$ & 118,4 \\
\hline $\begin{array}{l}\text { полезных ископаемых, кроме } \\
\text { топливно-энергетических }\end{array}$ & $113,4^{* *}$ \\
\hline $\begin{array}{l}\text { Металлургическое производство и } \\
\text { производство готовых металлических } \\
\text { изделий }\end{array}$ & $108,5^{* * *}$ \\
\hline
\end{tabular}

Примечание. Источник: Составлено на основе статистического бюллетеня «Основные показатели охраны окружающей среды». URL: http://www.gks.ru/.

* Базисные индексы промышленного производства рассчитаны на основании данных Росстата. Промышленное производство. URL: http:/www.gks.ru/wps/wcm/connect/rosstat main/rosstat/ru/statistics/ enterprise/industrial/\#.

** Индекс рассчитан на основе данных Российского статистического ежегодника 2017 г. «Общеэкономические показатели» и приведен за 2016 г. URL: http://www.gks.ru/bgd/regl/b17_13/Main.htm.

*** Индекс рассчитан на основе данных Российского статистического ежегодника 2017 г. «Общеэкономические показатели» и приведен за 2016 г. URL: http://www.gks.ru/bgd/regl/b17_13/Main.htm. С 2017 г. статья «Металлургическое производство и производство готовых металлических изделий» разбита на две: «Металлургическое производство» и «Производство готовых металлических изделий, кроме машин и оборудования».

Из таблиц 1.2 и 1.3 видно, что за период 2005-2017 гг. среднегодовой темп накопления отходов добычи полезных ископаемых составил около $6 \%$ при среднегодовом темпе роста их образования 7,5\% и темпе использования 9,1\%. В то же время прирост объемов добычи полезных ископаемых за указанный период составил всего $18,8 \%$. Это говорит о почти шестикратном превышении темпов накопления отходов над темпами роста добычи полезных ископаемых. Причем накапливаемая часть отходов учитывается после вычета использованных (утилизированных) отходов из образованных в процессе добычи.

По официальным данным, к 2001 г. на территории Российской Федерации в отвалах и хранилищах было накоплено свыше 85 млрд т только твердых отходов, в том числе 80 млрд т ГПО, количество которых ежегодно увеличивалось почти на 2 млрд т ${ }^{8}$. Если в течение 2001-2004 гг. накопление ГПО, основную массу которых составляют отходы добычи полезных ископаемых, увеличивалось примерно такими же темпами, как в 2005-2007 гг., т. е. в среднем 1390 млн т в год (табл. 1.2), то к 2005 г. общее накопление отходов добычи должно было составить свыше 84 млрд т. Исходя из данных государственной статистики (табл. 1.2), общий объем накопления неиспользованных отходов за четырнадцать лет (2005-2018 гг.) составил 33,163 млрд т., из них при добыче полезных ископаемых - 17,44 млрд т. Таким образом, основанный на официальных данных подсчет показывает, что к началу 2019 г. на

\footnotetext{
${ }^{8}$ Постановление Правительства РФ от 7 декабря 2001 г. № 860 (с изм. от 17 ноября 2005 г.) “О Федеральной целевой программе «Экология и природные ресурсы России (20022010 годы)»”. Подпрограмма «Отходы». URL: http://docs.procspb.ru/content/part/353846 (дата обращения: 15.07.2019).
} 
территории Российской Федерации накоплено отходов добычи полезных ископаемых не менее 113 млрд т, а всего отходов производства и потребления свыше 122 млрд т.

Осуществление горнодобывающей деятельности и связанных с ней обрабатывающих и энергетических производств неизбежно вызывает негативное воздействие на природную среду в районах освоения месторождений и использования минерального сырья. Характерными для горнодобывающего сектора видами негативных воздействий, наряду с образованием отходов, являются ухудшение качества атмосферного воздуха, загрязнение воды, шум и вибрация, значительное потребление энергоресурсов, воздействие на природные ландшафты и биоразнообразие. Серьезную опасность для водных объектов представляют участки хвостохранилищ, отвалов горных пород, где могут проходить процессы выщелачивания токсичных веществ, их просачивание сквозь почву и в конечном итоге загрязнение подземных вод, особенно если основания этих участков не выстелены водонепроницаемым материалом.

Отдельной проблемой является размещение хвостов обогащения, которые могут содержать высокие концентрации токсичных веществ (например, мышьяк, свинец, кадмий, хром, никель, цианид). На всех этапах жизненного цикла горнодобывающих предприятий (геологоразведки, эксплуатации месторождения и др.) происходят выбросы в атмосферу. В процессе перемещения пород в атмосферный воздух поступают мелкие частицы пыли (твердые взвешенные вещества). Источниками эмиссии выхлопных газов являются передвижные источники (машины, специальный транспорт и оборудование). Загрязняющие вещества в атмосферный воздух поступают в составе выбросов в процессе сгорания топлива в стационарных установках, при взрывных работах и переработке минерального сырья. Кроме пыли в составе выбросов содержатся тяжелые металлы, угарный газ, диоксид серы и оксиды азота.

По мере роста объемов добычи, ухудшения качества и усложнения условий добычи ТПИ возрастает интенсивность НВОС, что создает нарастающие проблемы для природных экосистем и населения в районах горнодобывающих производств.

\subsection{4. Основные причины роста накоплений отходов добычи и первичной переработки полезных ископаемых}

Сохранение тенденции к росту накопления отходов добычи и переработки является следствием увеличения их образования и недостаточно интенсивной переработки (утилизации), что обусловлено рядом взаимосвязанных факторов: горногеологических, горнотехнических, экономических, организационно-управленческих, правовых и институциональных.

Рост образования отходов при добыче полезных ископаемых связан с ростом объемов добычи, ухудшением горно-геологических условий ведения горных работ, низкой эффективностью применяемых технологий, существующей практикой предоставления месторождений в разработку.

Несмотря на то что рост промышленного производства в секторе добычи полезных ископаемых в 2005-2017 гг. был незначительным (18 \%), многолетняя отработка лучших участков недр с высококачественными запасами привела в целом к ухудшению качества остаточных запасов осваиваемых месторождений. Это, в свою очередь, определило необходимость вовлечения в эксплуатацию 
месторождений с более сложными горно-геологическими условиями и более низким содержанием полезного компонента.

За последние 15-20 лет содержание железа в рудах снизилось с 56-58 \% до 28-34 \%, произошел переход на добычу железистых кварцитов ${ }^{9}$. Если в конце XIX в. большая часть добываемых медных руд содержала 5-8 \% меди, в 1925 г. - 0,7-3 \%, то в конце 1970-х гг. уже 0,4-1,5\% [32]. Сегодня на крупнейших в России и уникальных по масштабу оруденения Октябрьском и Талнахском месторождениях среднее содержание меди составляет соответственно 1,61 и 1,1 $\%{ }^{10}$. Современные технологии позволяют обеспечивать рентабельность разработки участков недр с низким содержанием полезного компонента, однако для получения того же объема продукции требуется извлечение большего объема горной массы, следовательно, растут объемы отходов.

Ухудшение горно-геологических условий ведения горных работ, в частности понижение глубины отработки месторождений при открытом способе добычи, приводит к увеличению объемов извлекаемых пустых пород и низкокондиционных минеральных ресурсов, которые направляются в отвалы. Не случайно, например, наибольший рост отходов отмечается при добыче топливно-энергетических полезных ископаемых, в первую очередь угля, доля добычи которого открытым способом превышает $75 \%$.

Сложившиеся технологические условия ведения горных работ характеризуются высокой ресурсоемкостью, свойственной отечественной промышленности и экономике в целом. Ресурсоемкое горное оборудование оказывает высокую нагрузку на МСК Российской Федерации, не позволяет достаточно эффективно использовать запасы и ведет к часто практикующейся выборочной отработке богатых руд, что ухудшает структуру запасов. К примеру, в запасах уникального Октябрьского месторождения (Норильский горнопромышленный район) среднее содержание меди составляет 1,61 \%, никеля $0,84 \%$, платиноидов - 4,7 г/т, а в добываемых рудах они существенно выше: меди $-4,8 \%$, никеля - $1,9 \%$, платиноидов - 11,8 г/т.

Кроме того, отечественное горное производство отличается высоким уровнем потерь на стадиях добычи и переделов. Например, при осуществлении всех новых калийных проектов планируется использовать только традиционный (шахтный) способ добычи, при котором в недрах теряется в среднем до $60 \%$ руды. При переработке хибинских апатит-нефелиновых руд в отвалах фосфогипса ежегодно теряется такое количество (РЗЭ), которого хватило бы для удовлетворения всех мировых потребностей ${ }^{11}$.

9 О состоянии и использовании минерально-сырьевых ресурсов Российской Федерации в 2016 и 2017 годах: Государственный доклад // Центр «Минерал» ФГУНПП «Аэрогеология». 2018. C. 87. URL: http://www.mnr.gov.ru/docs/o_sostoyanii_i ispolzovanii_mineralno_syrevykh_resursov_rossiyskoy_federatsii/2017_doklad_o_sostoyanii _i_ispolzovanii_mineralno_syrevykh_resursov_rossiyskoy_federatsii/_- (дата обращения: 10.05.2019).

10 О состоянии и использовании минерально-сырьевых ресурсов Российской Федерации в 2016 и 2017 годах: Государственный доклад. Указ. соч. С. 128.

${ }^{11} \mathrm{O}$ состоянии и использовании минерально-сырьевых ресурсов Российской Федерации в 2011 году: Государственный доклад // Центр «Минерал» ФГУН ПП «Аэрогеология». 2012. URL: http://www.mineral.ru/Center/Announce/157/522/index.html. (дата обращения: 10.05.2019). 
При обогащении добытой руды потери могут составлять от 12 до 50 \%, что в среднем в два раза выше потерь в недрах при разработке месторождений [16]. Отвальные хвосты при производстве товарных железных руд, медных, цинковых и пиритных концентратов содержат значительное количество меди, цинка, серы, редких элементов.

Увеличению объемов накапливаемых отходов способствует отсутствие в системе государственного управления недропользованием подсистемы управления техногенными минеральными объектами (техногенными месторождениями), а также отсутствие правовых и технических регламентов формирования техногенных месторождений, установления прав собственности, единая система учета ${ }^{12}$. Не работает механизм ограничения на добычу полезных ископаемых при наличии в регионе источников ТМС данного вида. Примером может служить ситуация с предоставлением права пользования недрами месторождений общераспространенных полезных ископаемых. В Ленинградской области 70 \% минерально-сырьевого рынка формируют предприятия, производящие щебень из строительного камня, добываемого из природных месторождений. Ежегодный объем добычи общераспространенных полезных ископаемых в Ленинградской области 25,0-30,0 млн м $^{3}$ [104]. По области образуется порядка 6-10 млн т гранитных отсевов дробления (сухих хвостов), из которых можно дополнительно получать 4-8 млн т щебня мелких фракций и пески, которые с успехом можно применять в качестве заменителя природного песка, по физико-механическим и технологическим свойствам ничем не уступающие, а зачастую и превосходящие природные. Потери потенциального дохода при этом составляют от 80 млн до полутора миллиардов рублей в год. Под размещение отсевов ежегодно требуется 5-7 га земель; довольно распространенной практикой является использование естественных водоемов (озер) под размещение гранитных отсевов.

Другая сторона проблемы накопления отходов горного производства возможность их дальнейшей переработки. Следует учитывать, что горное производство представляет собой совокупность сложных, технологически и организационно связанных процессов. Зачастую переработка складируемых отходов невозможна без остановки связанного с ней производства и нарушения технологического цикла, поэтому разработку таких отходов можно вести только тогда, когда их отвалы уже сформированы (закрыты).

Одной из причин, сдерживающих переработку ранее сформированных лежалых отходов, является ухудшение с течением времени их качественного и количественного составов. Например, официальные потери при обогащении на предприятиях Кольской ГМК составляют до 30 \% в год, основные потери труднообогатимые хвосты флотации и шлаки, переработка которых предполагает весьма энергоемкое производство. В лежалых хвостах образуются кварц-сульфатные корки, что делает сквозное извлечение никеля очень низким.

В процессе долговременного хранения также изменяются физикомеханические свойства пород. Так, исследования пород вскрыши из отвалов Оленегорского железорудного месторождения, используемых в Мурманской

\footnotetext{
${ }^{12}$ Nevskaya M. A., Marinina O. A. Regulatory Aspects of Mining Waste Management in the Russian Federation. 2015 // Biosciences Biotechnology Research Asia: сайт. URL: http://www.biotech-asia.org/vol12no3/regulatory-aspects-of-mining-waste-management-inthe-russian-federation(дата обращения: 02.05.2019).
} 
области в качестве строительных материалов, показали ухудшение их прочностных характеристик (табл. 1.4) [113].

Таблица 1.4

Изменение показателя дробимости щебня из пород вскрыши отвалов Оленегорского железорудного месторождения в зависимости от сроков хранения

\begin{tabular}{|l|l|l|}
\hline \multirow{2}{*}{$\begin{array}{l}\text { Петрографический состав } \\
\text { щебня }\end{array}$} & \multicolumn{2}{|c|}{ Марка по дробимости } \\
\cline { 2 - 3 } & $\begin{array}{c}\text { срок хранения в } \\
\text { отвале 15-20 лет }\end{array}$ & $\begin{array}{c}\text { срок хранения в } \\
\text { отвале 20-25 лет }\end{array}$ \\
\hline $\begin{array}{l}\text { Амфибол-биотитовые гнейсы, } \\
\text { биотит-амфиболитовые гнейсы, } \\
\text { биотитовые гнейсы }\end{array}$ & От 800 до 600-800 & $\begin{array}{l}\text { От 200 до 400, } \\
\text { до 400-600 }\end{array}$ \\
\hline
\end{tabular}

Рынок минеральных ресурсов в России характеризуется высокой степенью монополизации, а производство ориентировано на экспорт. По данным Федеральной таможенной службы и Росстата, в 2018 г. доля минеральных продуктов в составе экспорта составила более $62 \%{ }^{13}$, в $2017-60,4 \%{ }^{14}$.

Разрабатывающие месторождения недропользователи могут рассматривать складируемые отходы добычи в качестве возможного источника минерального сырья, однако эффективность его использования будет определяться многими противоречивыми факторами. $\mathrm{K}$ ним относятся: содержание полезных компонентов в отходах и природном сырье, количество и качество техногенного сырья, издержки подготовки и включения отходов в технологический процесс, текущие и прогнозные цены на товарную продукцию и др. Изучение возможностей по критерию «выгоды - издержки» далеко не всегда позволяет сделать вывод о целесообразности организации переработки отходов добычи.

Переработка собственных ТМР для крупных недропользователей требует инициирования дорогостоящих высокорисковых инвестиционных проектов, что связано с поиском инновационных технологических решений и с выполнением полного цикла работ, начиная с геологической разведки и заканчивая постановкой содержащихся в отходах запасов на государственный баланс. В то же время рентабельность таких проектов и объем запасов полезных ископаемых в ТМО чаще всего ниже, чем у проектов освоения природных месторождений.

У горнодобывающих компаний, как правило, отсутствует апробированная технология переработки образованных ими отходов добычи, сброшенных в отвалы. Извлечение ценных компонентов из техногенного сырья связано с необходимостью совершенствования технологических решений и требует проведения дорогостоящих НИОКР с последующим составлением технологического регламента. Даже крупные российские горнодобывающие компании не всегда обладают необходимым научно-

\footnotetext{
13 Экспорт России важнейших товаров за январь - декабрь 2018 года // Федеральная таможенная служба: сайт. URL: http://customs.ru/folder/513 (дата обращения: 08.04.2019).

14 Товарная структура экспорта Российской Федерации // Федеральная служба государственной статистики: сайт. URL: http://www.gks.ru/wps/wcm/connect/ rosstat_main/rosstat/ru/statistics/ftrade/\# (дата обращения: 08.04.2019).
} 
техническим потенциалом, R\&D-подразделениями ${ }^{15}$ и другими возможностями. Поэтому переработка техногенных объектов не является приоритетным направлением их деятельности и ориентированы они на отработку разведанных природных месторождений.

\section{2. Проблема вовлечения отходов недропользования в хозяйственный оборот и пути ее решения}

\subsection{1. Несовериенство систем оценки и учета горнопромышленных отходов}

Вовлечение ГПО в хозяйственный оборот, наряду с предотвращением или сокращением их образования, является эффективным направлением снижения выбросов загрязняющих веществ и одновременно способом рационального использования ресурсного потенциала ТМС. Его развитию препятствует несовершенство механизма государственного регулирования и административного регламентирования сферы обращения с ГПО. Одним из проявлений этого несовершенства являются действующие методы оценки и учета ГПО.

В принятой системе оценки полезных ископаемых доминирует геологический подход, в основу которого заложены требования к определенному содержанию и объемам полезных компонентов, но не к технологии их извлечения и переработки. Как отмечают специалисты, геолого-экономическая оценка носит вероятностный характер и при подсчете промышленных запасов ТПИ коренных месторождений ошибка в подсчетном блоке рудного тела может составлять 25-60 \% [147]. Она может быть еще больше при подсчете запасов техногенных месторождений с нарушенной структурой полезных ископаемых.

Учет отходов (сбор, обобщение, систематизация, хранение, регистрация информации) является одним из функциональных компонентов управления отходами на всех стадиях их жизненного цикла и осуществляется в целях: обмена информацией для обеспечения внутри- и межведомственного взаимодействия органов управления, в ведении которых находятся отходы; предоставления информационных ресурсов заинтересованным лицам; формирования информационной среды бизнеса.

С 2014 г. в Российской Федерации установлена единая система ведения ГКО, который содержит в ФККО более 80 типов отходов добычи и переработки полезных ископаемых. ФККО не позволяет оценить ресурсный потенциал ГПО с позиций целесообразности их использования. Препятствиями для создания эффективной системы учета, а значит, и информационной среды обеспечения вовлечения отходов в хозяйственный оборот, являются: двойное регулирование деятельности, связанной с ГПО; отсутствие сопоставимости классификационных признаков отходов как объектов учета; отсутствие внутриведомственного взаимодействия и процедур передачи заинтересованным лицам информации об отходах горного производства; несогласованность систем учета.

Двойное регулирование проявляется в том, что учет ГПО в части отходов добычи и первичной переработки полезных ископаемых ведется в рамках экологического и горного законодательств по различным классификационным признакам. Основными параметрами, характеризующими

\footnotetext{
${ }^{15}$ От research and development, НИОКР.
} 
отходы с позиции экологического законодательства, являются вид, объем, содержание вредных компонентов, класс опасности, места размещения отходов.

Нормативная база горного законодательства хотя и оперирует термином «отходы добычи полезных ископаемых и связанных с ней перерабатывающих производств», но не дает ему определение, очевидно, в силу того, что объектами учета являются не массы отходов, а содержащиеся в них заnacbl полезных ископаемых u полезные компоненты, учет которых предусмотрен Государственным балансом запасов.

Информация о наиболее значимых техногенных минеральных объектах (техногенных месторождениях) содержится в Государственном кадастре месторождений полезных ископаемых, который ведется в соответствии со статьей 30 Закона «О недрах» [168] в целях обеспечения разработки федеральных и региональных программ геологического изучения недр, комплексного использования месторождений полезных ископаемых, рационального размещения предприятий по их добыче. Он содержит сведения по каждому месторождению, в том числе о залегающих полезных ископаемых, содержащихся компонентах, а также о горнотехнических, гидрогеологических, экологических и других условиях разработки месторождения.

Составление и внесение информации в кадастр месторождений осуществляет Федеральное агентство по недропользованию «Роснедра» на основании данных: государственной отчетности, представленной недропользователями, осуществляющими разведку и добычу; заключений государственной экспертизы запасов полезных ископаемых; территориальных балансов запасов полезных ископаемых, поступивших из территориальных фондов геологической информации; геологических отчетов о поисках, оценке и разведке месторождений.

Различия между системами учета проявляются и в принципах учета движения ГПО. Согласно экологическому законодательству он ведется по стадиям жизненного цикла отходов (начиная с их сбора и заканчивая утилизацией или обезвреживанием и захоронением). Горным законодательством предусматривается иная система, основанная на учете движения запасов полезных ископаемых (в том числе запасов в отходах горнодобывающих и связанных с ними перерабатывающих производств). Учет запасов осуществляется путем постановки их на государственный баланс, перевода из балансовых в забалансовые (и обратно), списания с баланса в виде потерь. Сравнение систем учета отходов представлено в табл. 1.5.

Таким образом, в настоящее время учет отходов горнодобывающих и связанных с ними перерабатывающих производств и запасов полезных ископаемых, содержащихся в данном виде отходов, представляют собой самостоятельные, фактически не связанные друг с другом системы учета, что затрудняет обмен информацией и согласование межведомственных интересов двух федеральных агентств Министерства природных ресурсов и экологии Российской Федерации (Росприроднадзора и Роснедр) в части регулирования деятельности с отходами. Также усложняется деятельность недропользователей по применению (утилизации) образуемых ими отходов и распоряжению ими. Ограничивается доступ к накопленным техногенным отходам организаций, включая малый горный бизнес, которые либо обладают технологиями переработки таких отходов и заинтересованы в применении этих технологий, либо обладают соответствующими компетенциями и 
заинтересованы в разработке инновационных технологий по переработке техногенных отходов, представляющих собой ВМР.

Таблицуа 1.5

Сравнительная характеристика двух систем учета отходов [88]

\begin{tabular}{|c|c|c|}
\hline \multirow[t]{2}{*}{ Признак сравнения } & \multicolumn{2}{|c|}{ Система учета отходов, основанная на нормах } \\
\hline & горного законодательства & экологического законодательства \\
\hline $\begin{array}{l}\text { Принципы } \\
\text { законодательства в } \\
\text { отношении отходов }\end{array}$ & $\begin{array}{l}\text { Отходы ГПП - } \\
\text { потенциальные ресурсы }\end{array}$ & $\begin{array}{l}\text { Отходы ГПП - потенциальные } \\
\text { угрозы окружающей среде }\end{array}$ \\
\hline $\begin{array}{l}\text { Квалификация } \\
\text { деятельности }\end{array}$ & $\begin{array}{l}\text { Использование отходов } \\
\text { ГПП квалифицируется как } \\
\text { деятельность, связанная с } \\
\text { пользованием недрами }\end{array}$ & $\begin{array}{l}\text { Сбор, транспортировка, накопление, } \\
\text { хранение (захоронение), } \\
\text { использование квалифицируются как } \\
\text { деятельность по обращению с } \\
\text { отходами }\end{array}$ \\
\hline Объект учета & $\begin{array}{l}\text { Запасы полезных } \\
\text { ископаемых, содержащиеся } \\
\text { в отходах }\end{array}$ & Масса отходов \\
\hline $\begin{array}{l}\text { Принцип организации } \\
\text { учета }\end{array}$ & $\begin{array}{l}\text { Учет в процессе движения } \\
\text { запасов по замкнутому } \\
\text { циклу }\end{array}$ & $\begin{array}{l}\text { Учет в процессе обращения отходов } \\
\text { по стадиям жизненного цикла: сбор, } \\
\text { транспортирование, использование, } \\
\text { хранение (захоронение) }\end{array}$ \\
\hline $\begin{array}{l}\text { Содержание категории } \\
\text { (отходы) }\end{array}$ & Не определено & $\begin{array}{l}\text { Несколько определений } \\
\text { Ф3 «Об отходах производства и } \\
\text { потребления» (от 24.06.1998 Ф3-89); } \\
\text { ГОСТ Р 53691-2009 }\end{array}$ \\
\hline $\begin{array}{l}\text { Признаки } \\
\text { квалификации }\end{array}$ & $\begin{array}{l}\text { Не установлены. } \\
\text { Учитываются объемы } \\
\text { запасов в отходах и } \\
\text { содержание полезных } \\
\text { компонентов } \\
\end{array}$ & $\begin{array}{l}\text { Класс опасности, вид, объемы, места } \\
\text { размещения, агрегатное состояние, } \\
\text { происхождение }\end{array}$ \\
\hline $\begin{array}{l}\text { Сфера применения } \\
\text { норм }\end{array}$ & Пользование недрами & Обращение с отходами \\
\hline Сроки хранения & Не ограничены & $\begin{array}{l}\text { Хранение отходов - размещение } \\
\text { отходов в специализированных } \\
\text { объектах сроком более чем } \\
\text { одиннадцать месяцев }\end{array}$ \\
\hline
\end{tabular}

Эффективным способом решения проблемы двойственности и неполноты учета ГПО как ТМР можно рассматривать создание на единой методологической основе системы кадастров ТМО, включающих региональные кадастры и специализированный ведомственный кадастр. Это позволит объединить разрозненные объекты в единую систему, доступную для изучения заинтересованным пользователям, в том числе малым горным предприятиям.

Целью системы кадастров ТМО является не только выполнение учетной функции, но и, главным образом, предоставление потенциальным инвесторам и другим заинтересованным лицам достаточно полной информации о ТМР, потенциально пригодных для переработки и извлечения ценных компонентов. Двойственность и несовершенство систем оценки и учета отходов горнодобывающих производств тесно связано с проблемой двойного регулирования их использования. 


\subsection{2. Противоречия в вопросах права собственности и использования отходов горнодобывающих производств}

Одним из главных факторов оборотоспособности отходов добычи и связанных с ней перерабатывающих производств является право собственности на данный вид отходов [98, 105], определяющее принципиальную возможность их вовлечения в хозяйственный оборот. Деятельность недропользователей, связанная с использованием образуемых ими отходов, подпадает под действие двух отраслей права — горного и экологического — и регулируется одновременно двумя законами федерального уровня (Законом РФ «О недрах» и Федеральным законом «Об отходах производства и потребления»). Законодательство о недрах рассматривает отходы горнодобывающих производств с позиций расширения МСБ, а законодательство об отходах рассматривает эти же отходы с позиций их НВОС.

Закон РФ «О недрах» (ст. 3, п. 3) [168] относит использование отходов добычи полезных ископаемых и связанных с ней перерабатывающих производств к виду пользования недрами, что требует оформления прав пользования отходами и получения лицензии (ст. 11) на их переработку, а также уплату НДПИ (предусмотрено Налоговым кодексом РФ, ст. 336, п. 2). В то же время в соответствии со ст. 1.2 Закона РФ «О недрах» добытые из недр полезные ископаемые и иные ресурсы (включая отходы добычи и переработки) по условиям лицензии могут находиться в федеральной, государственной собственности, собственности субъектов Российской Федерации, муниципальной, частной и в иных формах собственности, т. е. допускается собственность недропользователя на отходы по условиям лицензии.

На практике государственные органы управления недропользованием рассматривают использование отходов горнодобывающего производства как составную часть процесса добычи полезных ископаемых (ст. 6 Закона РФ «О недрах»). Из этого следует, что в лицензии на право пользования недрами может оговариваться лишь «право использования отходов и условие, определяющее это право» $[124$, с. 206], но не право собственности на отходы, которое закрепляется за государством вместе с правом собственности на недра. Закон РФ «О недрах», по сути, приравнивает отходы добычи и переработки к недвижсилым участкам недр, условия пользования которыми полностью определяются выданными лицензиями.

Таким образом, законодательство о недрах рассматривает лицензию (специальное разрешение на предоставление недр во временное пользование) как основной инструмент государственного регулирования деятельности по извлечению полезных компонентов из ТМС. Отношения в рамках этой деятельности регулируются нормами административного права, а главным администратором (полномочным представителем исполнительной власти) выступают Роснедра [54].

В отношении отходов горнодобывающего производства (включая отходы обогащения) законодательство о недрах вступает в противоречие с Гражданским кодексом РФ, который признает отходы движимым имуществом и наделяет правами собственности на них того, кто их образовал. До 1 января 2015 г. действовала норма ч. 3 ст. 4 Федерального закона № 89-Ф3 «Об отходах производства и потребления», которая непосредственно регулировала условия возникновения и передачи права собственности на отходы производства и потребления. Статья определяла, что право собственности на отходы принадлежит собственнику сырья, материалов, полуфабрикатов, в результате использования которых эти отходы образовались. 
Действующая редакция ст. 4 Федерального закона № 89-Ф3 «Об отходах производства и потребления» [169] гласит, что право собственности на отходы определяется в соответствии с гражданским законодательством. Каких-либо ограничений оборотоспособности отходов как объектов собственности, в том числе отходов добычи и переработки полезных ископаемых, Гражданский кодекс РФ не устанавливает. Первичное право собственности на отходы определяется исходя из норм ст. 220 Гражданского кодекса РФ и подразумевает переход права собственности с материалов на отходы, образовавшиеся в результате переработки материалов ${ }^{16}$.

Понятие «использование ${ }^{17}$ отходов» с 1 января 2015 г. заменено ${ }^{18}$ на понятие «утилизация» 19 , тем не менее содержание, по сути, не изменилось. Согласно определению, приведенному в ст. 1 Закона № 89-Ф3, утилизация это также использование отходов для производства товаров (продукции), выполнения работ, оказания услуг. Сравнение нормативно-правовых актов, регулирующих обращение (использование) с отходами добычи и обогащения минерального сырья, показано в табл. 1.6.

Двойное правовое регулирование обращения с отходами горнодобывающих производств (в части их использования) не способствует росту объемов переработки и затрудняет реализацию экологической политики государства, которая в качестве одного из механизмов решения задачи безопасного обращения с отходами предусматривает их использование путем вовлечения в повторный хозяйственный оборот (п. 15$)^{20}$.

Существующие юридические коллизии препятствуют включению механизма активного вовлечения в хозяйственный оборот ТМР, делают такое вовлечение экономически невыгодным, что отмечают многие исследователи данной проблемы. Однако в отношении способов устранения существующих на законодательном уровне противоречий нет однозначных точек зрения.

16 Бабина Ю. В. Право собственности на отходы и договорные отношения в области обращения с отходами // Справочник эколога. 2015. № 9. URL: https://www.profiz.ru/eco/9_2015/pravo_othody/ (дата обращения: 22.10.2019).

17 Использование отходов - применение отходов для производства товаров (продукции), выполнения работ, оказания услуг или для получения энергии (ст. 1 Федерального закона от 24 июня 1998 г. № 89-Ф3 «Об отходах производства и потребления», далее - Федеральный закон № 89-Ф3).

18 Введено Федеральным законом от 29 декабря 2014 г. № 458-Ф3 «О внесении изменений в Ф3 «Об отходах производства и потребления», отдельные законодательные акты РФ и признании утратившими силу отдельных законодательных актов (положений законодательных актов) РФ».

19 Утилизация отходов - использование отходов для производства товаров (продукции), выполнения работ, оказания услуг, включая повторное применение отходов, в том числе повторное применение отходов по прямому назначению (рециклинг), их возврат в производственный цикл после соответствующей подготовки (регенерация), а также извлечение полезных компонентов для их повторного применения (рекуперация) (ст. 1 Федерального закона № 89-Ф3).

${ }^{20}$ Основы государственной политики в области экологического развития в Российской Федерации на период до 2030 года: утв. Президентом РФ 30 апреля 2012 г. // КонсультантПлюс: офиц. интернет-портал. URL: http://www.consultant.ru/document/ cons_doc_LAW_129117/(дата обращения: 21.07.2019). 
Сравнение нормативно-правовых актов, регулирующих обращение с отходами (использование отходов) добычи и переработки [134]

\begin{tabular}{|c|c|c|}
\hline \multirow{4}{*}{ Признак сравнения } & \multicolumn{2}{|c|}{ Законодательство } \\
\hline & горное & экологическое \\
\hline & \multicolumn{2}{|c|}{ Отрасль права } \\
\hline & административное & гражданское \\
\hline Основной документ & Закон РФ «О недрах» & $\begin{array}{l}\text { Ф3 «Об отходах производства } \\
\text { и потребления» }\end{array}$ \\
\hline Понятие & $\begin{array}{l}\text { Отходы } \\
\text { горнодобывающего } \\
\text { и связанных с ним } \\
\text { перерабатывающих } \\
\text { производств }\end{array}$ & $\begin{array}{l}\text { Отходы производства и } \\
\text { потребления }\end{array}$ \\
\hline Содержание понятия & Не определено & Несколько определений \\
\hline Признаки классификации & Не определено & $\begin{array}{l}\text { Класс опасности, вид и } \\
\text { объемы, состояние, тип }\end{array}$ \\
\hline Сфера применения норм & Пользование недрами & Обращение с отходами \\
\hline $\begin{array}{l}\text { Право собственности на } \\
\text { отходы }\end{array}$ & Строго не закреплено & $\begin{array}{l}\text { Закреплено за } \\
\text { хозяйствующим субъектом }\end{array}$ \\
\hline $\begin{array}{l}\text { Возникновение прав } \\
\text { собственности }\end{array}$ & $\begin{array}{l}\text { 1. В процессе } \\
\text { недропользования } \\
\text { 2. В результате } \\
\text { приобретения лицензии } \\
\text { на право отработки } \\
\end{array}$ & $\begin{array}{l}\text { Не приобретается. } \\
\text { Возникает в процессе } \\
\text { хозяйственной деятельности }\end{array}$ \\
\hline $\begin{array}{l}\text { Передача прав } \\
\text { собственности другому } \\
\text { лицу }\end{array}$ & Не передается & $\begin{array}{l}\text { На основе гражданских } \\
\text { сделок }\end{array}$ \\
\hline $\begin{array}{l}\text { Условия приобретения } \\
\text { прав собственности } \\
\text { другим лицом }\end{array}$ & $\begin{array}{l}\text { Через процедуру } \\
\text { лицензирования }\end{array}$ & $\begin{array}{l}\text { На основе гражданских } \\
\text { сделок }\end{array}$ \\
\hline $\begin{array}{l}\text { Условия отчуждения } \\
\text { (изъятия) }\end{array}$ & $\begin{array}{l}\text { Истечение срока действия } \\
\text { лицензии. } \\
\text { Ликвидация деятельности }\end{array}$ & Решение суда \\
\hline $\begin{array}{l}\text { Права собственности на } \\
\text { брошенные отходы }\end{array}$ & $\begin{array}{l}\text { Принадлежат } \\
\text { государству }\end{array}$ & $\begin{array}{l}\text { Принадлежат владельцу } \\
\text { земельного участка }\end{array}$ \\
\hline
\end{tabular}

\subsection{3. Анализ методов и инструментов государственного регулирования в области использования отходов горного производства}

Позиция, согласно которой техногенные минеральные объекты могут и должны рассматриваться в качестве техногенных месторождений, основана на конщепщии сохранения ресурсного потенщиала, восполнения МСБ и предотвращения незаконного оборота техногенных образований, содержащих уникальные ресурсы. Эта концепция отражена в научных работах и публикациях К. Н. Трубецкого, 
В. Н. Уманца， А. В. Когута， О. Е. Горловой， Б. К. Михайлова， Ю. А. Кипермана, Л. З. Быховского, А. Б. Макарова, В. В. Чайникова, А. И. Некрасова и др.

Согласно концепции сохранения ресурсного потенциала ТМ рассматривается как сложный геологический объект, в соответствии с чем на тех, кто будет его разрабатывать, автоматически возлагается обязанность выполнения всех стадий геологоразведочных работ, прохождения конкурсных и иных процедур, связанных с постановкой ТМ на кадастровых учет. С. Г. Селезнев отмечает, что стоимость геологоразведочных работ существенно влияет на итоговую инвестиционную эффективность переработки ТМО, а их продолжительность сопоставима со сроками эксплуатации самого объекта (в некоторых случаях, например при переработке техногенных россыпей, может их превышать) [113].

Н. Б. Карпенко, Б. К. Кавчик, Ю. А. Кацман также отмечают, что разработка техногенных месторождений, в частности золота, сдерживается заложенными при получении доступа к ним «принципами освоения крупных месторождений, такими как: многостадийная разведка; разработка ТЭО временных и постоянных кондиций; утверждение запасов в ГКЗ или ТКЗ полезных ископаемых; согласование проектов во многих инстанциях, утверждение технологических потерь» ${ }^{21}$, требующими значительных затрат времени и иных ресурсов, в связи с чем встает вопрос и об инвестиционной привлекательности таких объектов, расположенных к тому же в малонаселенных и малопривлекательных районах.

Сторонники данной позиции обращают внимание на нелегитимность применения понятия «техногенное месторождение» как фактора, усложняющего процедуры и сдерживающего вовлечение в разработку техногенных минеральных объектов, обладающих высоким ресурсным потенциалом. Неоднозначное отношение у исследователей и к проблеме прав собственности на ГПО, которую мы обсуждали в предыдущем подразделе. Однако, несмотря на различие во взглядах по отдельным вопросам, все стороны сходятся во мнении о необходимости совершенствования нормативной правовой базы в области использования отходов добычи полезных ископаемых и связанных с ней перерабатывающих производств.

Анализ законодательной базы позволяет классифицировать основные нормативно-правовые акты в области управления ГПО по трем признакам: 1) нормативно-правовые акты, определяющие общую концепцию, политику и механизмы государства в сфере обращения с отходами и экологической безопасности; 2) нормативно-правовые акты, регулирующие деятельность в сфере обращения с отходами добычи и переработки полезных ископаемых; 3) подзаконные акты, формирующие комплекс инструментов и методов регулирования обращения с отходами (рис. 1.1).

${ }^{21}$ Карпенко Н. Б. Правовые аспекты учета и переработки техногенных месторождений 2010 // Золотодобыча: сайт. URL: http://zolotodb.ru/articles/docs/discuss/10401 (дата обращения: 20.07.2019). 


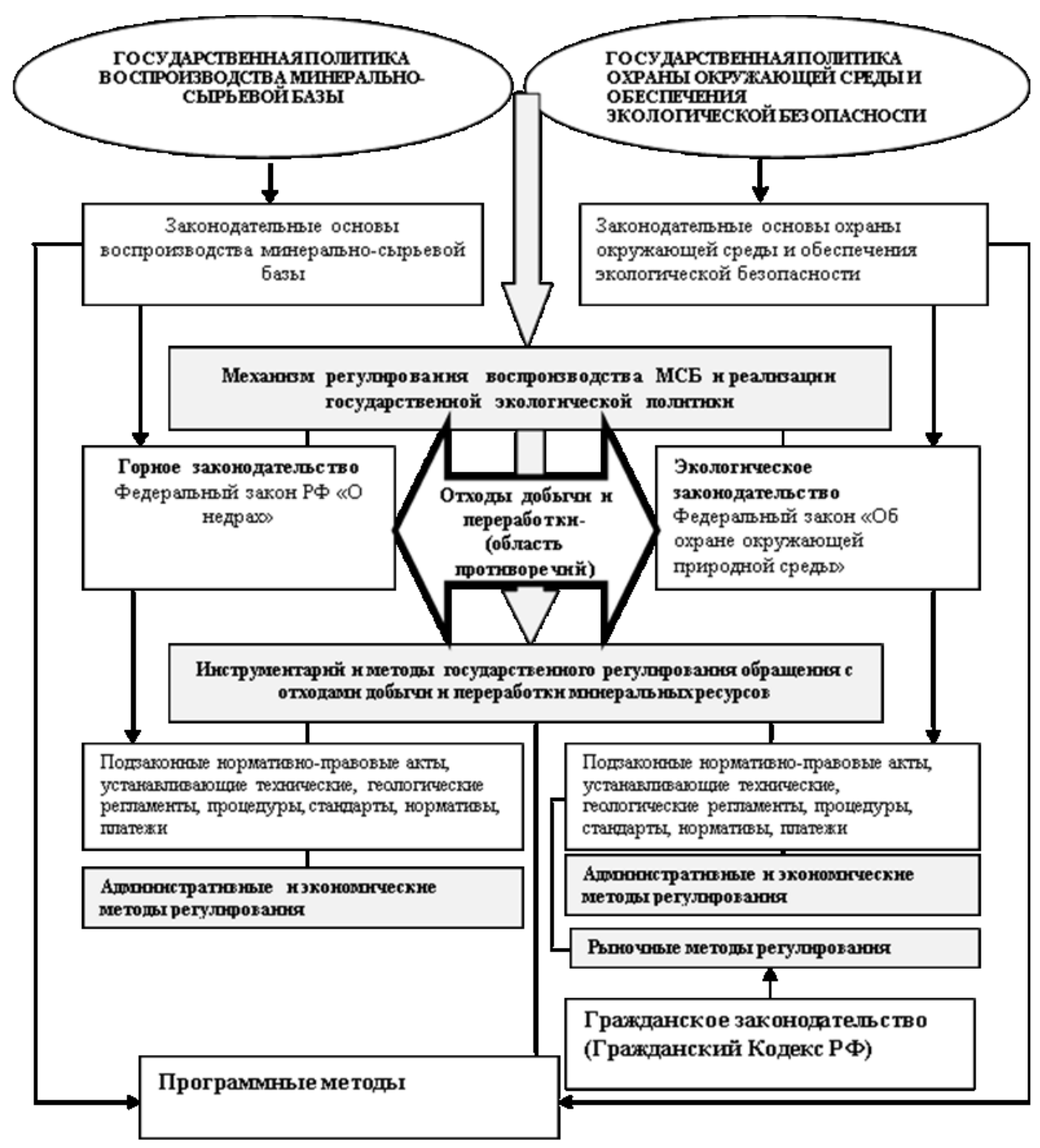

Рис. 1.1. Схема формирования методов и инструментов государственного регулирования обращения с отходами добычи и переработки на основе нормативно-правовой базы [136]

Для недропользователей как субъектов хозяйствования можно выделить три группы основных методов регулирования обращения с отходами: административные, экономические и программно-целевые ${ }^{22}$. Горное законодательство, как и экологическое, предусматривает широкий спектр административных методов, которые можно разделить на три группы: 1) методы, определяющие процедуры в отношении деятельности, связанной с отходами (лицензирование, техническая, геологическая и экологическая экспертиза и др.); 2) методы, устанавливающие степень соответствия

22 Кузнецов Ю. В. Методы государственного регулирования экономики // Проблемы взаимодействия хозяйствующих субъектов реального сектора экономики России: финансово-экономический, социально-политический, правовой и гуманитарный аспекты. СПб.: СПбГУ, 2011. URL: http://www.ibl.ru/konf/151211/metodygosudarstvennogo-regulirovanija.html (дата обращения: 10.03.2019). 
деятельности, связанной с отходами, установленным техническим и экологическим стандартам и нормативам (нормативы потерь и разубоживания, показатели содержания полезных компонентов в отходах, класс опасности, нормативы платы и т. п.); 3) методы сбора и обобщения информации (статистический и кадастровый учеты, горный аудит, мониторинг и т. п.).

Таблица 1.7

\section{Характеристики административных методов горного и экологического законодательств [134]}

\begin{tabular}{|c|c|c|}
\hline Характеристика & Закон РФ «О недрах» & $\begin{array}{c}\text { Ф3 «Об охране окружающей } \\
\text { среды», Ф3 «Об отходах } \\
\text { производства и потребления» }\end{array}$ \\
\hline \multicolumn{3}{|c|}{ Методы проведения организационных прочеедур } \\
\hline $\begin{array}{l}\text { Лицензирование } \\
\text { деятельности с отходами } \\
\text { добычи и переработки }\end{array}$ & Предусмотрена & $\begin{array}{l}\text { Не предусмотрена } \\
\text { (лицензированию подлежит } \\
\text { деятельность, связанная с } \\
\text { транспортировкой и } \\
\text { захоронением отходов) }\end{array}$ \\
\hline Геологическая экспертиза & Предусмотрена & - \\
\hline $\begin{array}{l}\text { Техническая экспертиза } \\
\text { проектов переработки } \\
\text { отходов }\end{array}$ & $\begin{array}{l}\text { Проектов переработки } \\
\text { отходов }\end{array}$ & - \\
\hline Экологическая экспертиза & - & Предусмотрена \\
\hline \multicolumn{3}{|c|}{ Методы контроля } \\
\hline $\begin{array}{l}\text { Нормативы потерь, } \\
\text { разубоживания полезного } \\
\text { ископаемого }\end{array}$ & Предусмотрены & - \\
\hline $\begin{array}{l}\text { Содержание полезных } \\
\text { компонентов }\end{array}$ & Предусмотрены & - \\
\hline $\begin{array}{l}\text { Нормативы содержания } \\
\text { вредных примесей и } \\
\text { веществ }\end{array}$ & - & Установлены \\
\hline $\begin{array}{l}\text { Норматив платы за } \\
\text { размещение отходов }\end{array}$ & - & Установлен \\
\hline \multicolumn{3}{|c|}{ Методы сбора и обобщения информации } \\
\hline Горный аудит & Предусмотрен & - \\
\hline Экологический мониторинг & - & Предусмотрен \\
\hline Кадастровый учет & $\begin{array}{l}\text { Предусмотрен учет } \\
\text { техногенных } \\
\text { месторождений в кадастре } \\
\text { месторождений и } \\
\text { проявлений полезных } \\
\text { ископаемых в ГБ3 } \\
\end{array}$ & $\begin{array}{l}\text { Предусмотрен учет в реестре и } \\
\text { кадастре отходов }\end{array}$ \\
\hline Статистический учет & $\begin{array}{l}\text { Предусмотрен по форме } \\
\text { статистического учета 71- } \\
\text { тп }\end{array}$ & $\begin{array}{l}\text { Форма 2-тп - отходы } \\
\text { предусмотрена для } \\
\text { непромышленных отходов } \\
\text { производства и потребления }\end{array}$ \\
\hline
\end{tabular}


Сравнение приведенных методов позволяет сделать вывод о том, что существуют противоречия между административными методами, предусмотренными нормативно-правовыми актами горного и экологического законодательства в области лицензирования деятельности с отходами и их учета (табл. 1.7).

Основными недостатками действующих методов экономического стимулирования использования отходов являются: ограниченная область применения (например, методы ускоренной амортизации работают, когда организация повышает эффективность своей деятельности, т. е. объемы производства растут); низкая мотивационная составляющая (плата за размещение отходов не является экономически обоснованным стимулом и носит фискальный характер); деятельность пользователя недрами, связанная с использованием собственных отходов добычи и обогащения, по формальным признакам (квалификация этого вида деятельности как пользование недрами) не позволяет эффективно применять экономические стимулы, предусмотренные экологическим законодательством.

Несмотря на ограниченность методов экономического стимулирования, экологическое законодательство обладает потенциалом для внедрения рыночных механизмов и методов регулирования, основанных на гражданско-правовых нормах. Это дает возможность внедрять более адаптированные к рыночным условиям формы организации взаимодействия между хозяйствующими субъектами и применять рыночные методы регулирования их отношений.

Третья группа методов (программные методы) традиционно рассматривается как способ формирования системы плановых решений крупных социальноэкономических проблем. В качестве основного инструмента государственного регулирования обращения с отходами посредством применения программного метода выступают государственные (отраслевые, региональные, федеральные) целевые программы [7]. Можно сделать вывод, что условиями применения программно-целевых методов являются: наличие крупной актуальной проблемы, решение которой невозможно другими методами; стабильная финансовая ситуация, позволяющая планировать бюджет программы; отсутствие радикальных изменений в государственных структурах управления.

\subsection{4. Формирование институциональной среды управления отходами горнодобывающих производств в условиях экологизации и внедрения наилучших доступных технологий}

Масштаб и характер проблем, связанных с отходами горнодобывающих производств, требуют их рассмотрения в институциональном аспекте, когда они выступают объектом управления в существующей институциональной среде. Институциональной средой для такого объекта будет являться совокупность политических, социальных и юридических норм и правил, образующих базис горнодобывающего производства, обмена и распределения [154]. В формировании институциональной среды главная роль отводится государству, устанавливающему «жесткие формы» институциональных отношений либо создающему условия для участников, позволяющие им самим формировать институциональные отношения [43]. 
Необходимость рассмотрения институционального аспекта обусловлена рядом причин, среди которых: сохранение тенденции к росту образования и накопления отходов добычи и переработки в объемах, не позволяющих решить эту проблему в рамках минерально-сырьевого комплекса; потребность в правовом регулировании хозяйственных отношений в сфере обращения с отходами горнодобывающего производства, рост требований к способности правовой системы обеспечивать надлежащее регулирование этих отношений; необходимость в четких процедурах, правилах и требованиях, позволяющих развивать формы хозяйственного взаимодействия в сфере обращения с отходами, а также эффективно управлять этим процессом; развитие новой институциональной теории, включая теорию прав собственности. Основным инструментом установления форм институциональных отношений в недропользовании является его ресурсный или нормативно-правовой режим [61].

Управление отходами горного производства может одновременно рассматриваться как реализация основных управленческих функций (учет, контроль, анализ, планирование, организация) и как организационно-производственная деятельность по сбору, накоплению, переработке, использованию (утилизации), обезвреживанию, размещению отходов [54]. Управление отходами горного производства - это, прежде всего, управление обращением с данным типом отходов.

Специфика таких отходов в том, что большинство из них по своему вещественному составу пригодны для дальнейшего использования как ВМР. Вместе с тем их переработка в рамках действующих технологий практически невозможна без остановки связанного с ними производства и нарушения технологического цикла. Поэтому решение этой проблемы возможно путем: 1) реорганизации всего производственного процесса, что связано со значительными инвестициями в расширение, реконструкцию, модернизацию производства; 2) включения в организационно-производственный процесс управления отходами новых участников, выполняющих либо отдельные функции, либо весь комплекс работ.

Деятельность участников процесса управления отходами горного производства должна обеспечиваться условиями, которые формируются институциональной средой. Используя наиболее распространенные определения основных категорий институциональной теории, мы определили институциональную среду управления отходами горного производства как систему институтов (правил и норм), формирующих условия для вовлечения таких отходов в хозяйственный оборот.

По отношению к институциональной среде управления отходами горного производства система базовых политических и экономических институтов, таких как институт частной собственности, государство, законодательная система, выступает в качестве внешней среды, определяющей границы функционирования среды управления отходами горного производства. В свою очередь, эта институциональная среда в значительной степени определяет качество и эколого-экономическую эффективность управления отходами на уровне горнодобывающих компаний и отдельных производств.

Положительным примером влияния институциональной среды на организацию эффективного управления отходами горного производства является ситуация в странах Европейского союза. Законодательство стран ЕС, опирающееся на принципы экоэффективности, позволяет выстраивать различные схемы взаимодействия участников процесса управления отходами горнодобывающей 
промышленности. Действенность их институциональной среды обеспечивается: правом частной собственности на отходы, определяющим степень ответственности за их образование и использование; активной политикой ресурсосбережения и энергоэффективности; наличием нормативных правовых актов, регулирующих обращение с отходами горнодобывающей промышленности; тесной взаимосвязью центральных и региональных органов управления.

Управление отходами горнодобывающей промышленности стран ЕС регулируется горным кодексом и экологическими нормами, которые предусматривают образование отходов в виде экологической нагрузки начиная с этапов оценки и проектирования месторождений. В 2006 г. была принята Директива 2006/21/ЕС Европейского парламента и Совета ЕС «Об управлении отходами горнодобывающей промышленности», которая регламентирует обращение с отходами, образующимися в результате извлечения, обработки и хранения полезных ископаемых и эксплуатации карьеров. В соответствии с директивой государства члены ЕС должны гарантировать, что хозяйствующие субъекты, эксплуатирующие сооружения для обработки отходов, будут составлять план по управлению ими, который корректируется каждые пять лет и ориентирован [124]: на предотвращение или сокращение образования отходов и их НВОС; стимулирование утилизации отходов посредством их использования в качестве ВМР; стимулирование безопасного краткосрочного и долгосрочного размещения отходов.

В Европейском справочнике по НДТ «Обращение с отходами и пустыми породами горнодобывающей промышленности» зафиксирована норма о том, что выбор методов обращения с отходами горнодобывающей промышленности определяется уровнем затрат, экологическим фактором, риском возникновения чрезвычайной ситуации и негативных последствий. Концептуально обращение с отходами базируется на стремлении достичь за счет НДТ экологической результативности с опорой на оценку экономической жизнеспособности технологий и рисков, определяемых местными условиями.

Были выделены признаки, характеризующие условия управления отходами горнодобывающего производства в странах Европейского союза и Российской Федерации: самостоятельность сферы управления отходами добычи и переработки; обеспеченность нормативно-правовыми ресурсами в области управления отходами горнодобывающей промышленности; адекватность механизма управления рыночным условиям хозяйствования; основная форма взаимодействия между субъектами управления отходами; сбалансированность институциональных интересов [89]. В табл. 1.8 показаны различия условий управления отходами горного производства в странах ЕС и России в соответствии с вышеприведенными признаками.

Исследования показали, что в ряде стран с развитой горнодобывающей промышленностью базовыми факторами при формировании сферы обращения с отходами добычи и переработки полезных ископаемых являются: экокультура, экологическое сознание и воспитание, трансформированные в элементы государственной политики; законодательство, идеологический стержень которого составляет принцип экоэффективности; институт малого и среднего предпринимательства в сфере обращения с отходами добычи и переработки; научно-исследовательские центры развития, одна из задач которых организация взаимодействия горных компаний с малым и средним бизнесом; муниципальные и региональные надзорные и координирующие органы, являющиеся частью системы управления отходами. 
Сравнение условий управления отходами горного производства в странах ЕС и России [89]

\begin{tabular}{|c|c|c|}
\hline \multirow{2}{*}{ Признак } & \multicolumn{2}{|c|}{ Условия управления отходами горного производства } \\
\hline & в странах Европейского союза & в Российской Федерации \\
\hline $\begin{array}{l}\text { Самостоятельность } \\
\text { сферы управления } \\
\text { отходами }\end{array}$ & $\begin{array}{l}\text { Выделено в самостоятельную } \\
\text { сферу институционального } \\
\text { регулирования }\end{array}$ & $\begin{array}{l}\text { Не выделено в } \\
\text { самостоятельную сферу } \\
\text { институционального } \\
\text { регулирования }\end{array}$ \\
\hline $\begin{array}{l}\text { Обеспеченность } \\
\text { нормативно- } \\
\text { правовыми } \\
\text { ресурсами }\end{array}$ & $\begin{array}{l}\text { Наличие самостоятельных } \\
\text { нормативно-правовых актов в } \\
\text { сфере управления отходами } \\
\text { горного производства }\end{array}$ & $\begin{array}{l}\text { Отсутствуют } \\
\text { самостоятельные } \\
\text { нормативно-правовые акты } \\
\text { в сфере управления } \\
\text { отходами горного } \\
\text { производства } \\
\end{array}$ \\
\hline $\begin{array}{l}\text { Адаптивность } \\
\text { механизма } \\
\text { управления } \\
\text { отходами горного } \\
\text { производства } \\
\text { рыночным условиям } \\
\text { хозяйствования }\end{array}$ & $\begin{array}{l}\text { Гибкий механизм } \\
\text { управления, основанный на } \\
\text { многообразии форм } \\
\text { взаимодействия между } \\
\text { субъектами управления } \\
\text { отходами }\end{array}$ & $\begin{array}{l}\text { Жесткий механизм } \\
\text { управления, встроенный в } \\
\text { систему управления } \\
\text { недропользованием }\end{array}$ \\
\hline $\begin{array}{l}\text { Основная форма } \\
\text { взаимодействия } \\
\text { субъектов } \\
\text { управления } \\
\text { отходами горного } \\
\text { производства }\end{array}$ & Контрактная & Разрешительная \\
\hline $\begin{array}{l}\text { Институциональные } \\
\text { интересы }\end{array}$ & Сбалансированы & $\begin{array}{l}\text { Сбалансированы только } \\
\text { в рамках программ }\end{array}$ \\
\hline
\end{tabular}

В странах Европейского союза, где экологическая составляющая рассматривается как основной признак эффективности переработки отходов, сфера управления отходами горнодобывающего производства является показательным примером институциональной сбалансированности экологической безопасности и социальной стабильности. В Российской Федерации основным способом решения проблемы ГПО на государственном уровне выступают государственные целевые программы. Такой же практики придерживается ряд других стран, например Канада и США, где развито управление отходами добычи и переработки посредством разработки и реализации различных экологических и природоохранных программ.

С полноценным введением в действие в Российской Федерации с 2019 г. новой системы экологического регулирования на основе внедрения НДТ и выдачи комплексных экологических разрешений на эксплуатацию установок I категории возникает новая ситуация. Институциональная среда управления ГПО становится более развитой, но пока еще остается много вопросов с точки зрения практической реализации принятых на законодательном уровне решений. 
Анализ показывает, что вводимые в рамках нового экологического регулирования экономические стимулы не фокусируют внимание горных компаний на ключевой проблеме - недостатке высокотехнологичных производств. Доступность НДТ не может быть обеспечена простым заимствованием зарубежных разработок, поскольку составы минерального сырья и схемы его обогащения в каждом случае индивидуальны [159].

Проблему эффективной переработки отходов недропользования нельзя решить только нормами экологического права. Они должны дополняться государственной поддержкой проектов создания эффективных технологических схем переработки техногенного сырья, реализуемых на принципах государственно-частного партнерства. «Обкатанные» на техногенных отходах инновационные решения могут стать наилучшими доступными технологиями, в том числе для комплексной переработки многокомпонентного природного сырья, что создаст предпосылки для перехода горной отрасли на новый технологический уровень [159].

\section{3. Совершенствование налоговой политики в области комплексного использования минерального сырья и отходов его переработки}

\subsection{1. Сочетание фискальной и регулирующей функций налогов с целью наиболее полного извлечения полезных компонентов из минерального сырья}

Рациональность освоения запасов ТПИ и экономическая эффективность горнодобывающих производств во многом определяются системой налогообложения горного бизнеса и характером налоговой политики государства. Рациональная в данном сегменте недропользования налоговая политика заключается в том, чтобы обеспечить изъятие в бюджетную систему дохода от добычи ТПИ, не связанного с предпринимательской деятельностью (горной ренты), и одновременно стимулировать деловую активность горного бизнеса, его стремление комплексно использовать минеральные ресурсы недр при соблюдении установленных законодательных и проектных ограничений.

В Российской Федерации для целей изъятия горной ренты применяется ряд фискальных инструментов: неналоговые платежи за недропользование, налог на добычу полезных ископаемых, налог на прибыль организаций, таможенные пошлины. Существующие подходы к налогообложению горнодобывающих предприятий нельзя признать рациональными в силу многокомпонентности состава преобладающей части минерального сырья и отсутствия такой налоговой политики, которая бы стимулировала недропользователей внедрять малоотходные технологии, обеспечивающие комплексное извлечение в товарный продукт всех ценных компонентов добываемой руды. Преобладает явно выраженная фискальная функция налогообложения, которая по отношению к полноте освоения минеральных ресурсов, комплексности использования как природного сырья, так и ТМС, по нашему мнению, скорее, дестимулирует переход на инновационные и доступные малоотходные технологии, чем способствует этому.

Проблемы налогообложения российских компаний, осуществляющих добычу и комплексную переработку минерального сырья, являются актуальными в 
отношении основных видов полезных ископаемых, а также полезных ископаемых, добываемых попутно, в том числе попутно выделяемых на всех последующих стадиях комплексной переработки минерального сырья. Е. И. Панфилов ${ }^{23}$ считает термины «рациональное» и «комплексное» по отношению к добыче и переработке полиметаллических руд взаимосвязанными по своей сущности и разделяемыми условно наряду с понятием «сохранение минеральных ресурсов».

Как правило, российские компании осуществляют добычу и комплексную переработку только основных полезных ископаемых или компонентов. Попутные виды полезных ископаемых, попутные компоненты и попутная продукция, полученные при добыче и комплексной переработке минерального сырья, уходят в отходы. Это приводит к потере значительного количества полезных ископаемых и полезных компонентов, которые по стоимостной оценке могут превосходить основные продукты и, в свою очередь, должны являться объектами обложения налогом на добычу полезных ископаемых. Следовательно, уменьшается налогооблагаемая база и государственный бюджет, недропользователи недополучают доходы, замедляется экономический рост.

В настоящее время отсутствует государственная поддержка недропользователей, стимулирующая максимально полное извлечение всех полезных компонентов, требуют развития регулирующие функции налогов, направленные на вовлечение в переработку ВМР. Решение проблемы увеличения доходов бюджетов на основе повышения уровня добычи и эффективности комплексной переработки минерального сырья, включая поиск дополнительных источников налоговых поступлений в бюджеты бюджетной системы Российской Федерации от вовлечения в переработку ТМР, требует разработки методологии налогообложения организаций по добыче и комплексной переработке минерального сырья.

Налогообложение добычи ТПИ в настоящее время рассматривается фрагментарно, а не в системе, которая бы отражала полный отраслевой цикл комплексного использования минерального сырья по цепочке внутриотраслевых организационно-технологических процессов, включающей: 1) учет промышленных запасов ТПИ; 2) добычу полезных ископаемых, определение потерь полезных ископаемых; 3) комплексную переработку минерального сырья; 4) создание добавленной стоимости в структуре комплексных производств; 5) реализацию продукции; 6) вовлечение в переработку эксплуатационных и технологических потерь (отходов); 7) вовлечение в переработку ТМС по отдельной лицензии. Применяемые методы определения объектов налогообложения и формирования налоговых баз по налогу на прибыль организаций, возмещения НДС при экспортных операциях в системе налогообложения добычи и комплексной переработки минерального сырья требуют совершенствования в силу существующих пробелов в законодательстве о налогах и сборах Российской Федерации.

С истощением запасов богатых руд обнаруживается, что содержание полезных компонентов в эксплуатационных потерях при добыче и в технологических потерях при комплексной переработке минерального сырья стало превышать их содержание в природных месторождениях, вовлекаемых в

23 Панфилов Е. И. О концепции рационального комплексного освоения георесурсов и сохранения недр // Горная промышленность. 2006. № 1 (63). URL: https://miningmedia.ru/ru/article/ekonomic/1165 (дата обращения: 13.11.2019). 
разработку. В результате эксплуатационные и технологические потери начали представлять экономический интерес на предмет извлечения из них полезных компонентов. Однако широкомасштабная переработка ТМС в Российской Федерации сдерживается несовершенством действующей системы обложения налогом на добычу полезных ископаемых. При этом показатели эффективности комплексного использования минерального сырья (содержание полезного компонента и уровень сквозного извлечения компонентов в реализуемые виды продукции) не являются критериями эффективности разработки месторождений ТПИ. Например, в угольных бассейнах в качестве полезных компонентов присутствуют золото, серебро, кварц, но они уходят в технологические потери, поскольку являются попутными полезными компонентами, доизвлечение которых потребует разработки новых технологий. В результате из объекта, облагаемого НДПИ, исключаются попутные компоненты, которые не поименованы в лицензии на право пользования недрами. Экономические последствия этого - снижение поступлений НДПИ в бюджеты бюджетной системы Российской Федерации.

Анализ структуры потерь полезных компонентов при добыче и переработке полиметаллов показал, что около 20-25 \% технологических потерь приходится на передел комплексной переработки минерального сырья, около 25 $\%$ теряется при добыче и до 50-55\% в процессе обогащения. Соотношение полезных компонентов и потерь за 2002-2013 гг. приведено в табл. 1.9.

Таблийа 1.9

Соотношение полезных компонентов и потерь при переработке полиметаллических руд в России, \%

\begin{tabular}{|l|c|c|c|c|c|c|}
\hline \multirow{2}{*}{ Компонент } & \multicolumn{5}{|c|}{ Концентрат } & Потери \\
\cline { 2 - 6 } & свинцовый & цинковый & медный & баритовый & прочие & \\
\hline Свинец & 75,50 & 4,60 & 1,90 & 0,60 & 0,40 & 17,00 \\
\hline Цинк & 5,40 & 74,70 & 2,30 & 0,15 & 0,05 & 17,40 \\
\hline Медь & 5,50 & 8,50 & 75,80 & 0,10 & 0,10 & 10,00 \\
\hline Золото & 23,80 & 5,60 & 32,70 & 0,10 & 9,90 & 27,90 \\
\hline Серебро & 45,70 & 9,40 & 19,90 & 0,20 & 1,20 & 23,60 \\
\hline Барит & 0,20 & 0,10 & - & 54,90 & - & 44,80 \\
\hline Сера & 12,00 & 31,90 & 3,00 & 1,40 & 4,70 & 42,00 \\
\hline Железо & 3,20 & 3,40 & 17,00 & 0,40 & 3,50 & 72,50 \\
\hline Кадмий & 11,00 & 77,90 & 2,00 & - & 0,10 & 9,00 \\
\hline Мышьяк & 11,30 & 28,50 & 10,00 & 0,50 & 0,80 & 48,90 \\
\hline Сурьма & 30,30 & 8,60 & 41,10 & 0,20 & 0,80 & 19,00 \\
\hline Индий & 4,80 & 11,70 & 1,20 & - & - & 82,30 \\
\hline Таллий & 9,20 & 3,70 & - & - & - & 87,10 \\
\hline Селен & 22,70 & 5,00 & - & - & - & 72,30 \\
\hline Теллур & 9,00 & 1,60 & - & - & - & 89,40 \\
\hline Висмут & 48,30 & 8,50 & 12,80 & - & - & 30,40 \\
\hline Олово & 0,10 & 2,20 & 5,70 & 0,20 & 0,10 & 91,70 \\
\hline
\end{tabular}

Примечание. Источник: [12]. 
При переработке на различных стадиях технологического процесса теряется свыше 20 \% общей ценности свинца, цинка, меди, барита, благородных металлов и основная масса малых металлов, редких рассеянных элементов, а часть основных цветных металлов переходит в разноименные концентраты. Структура видов потерь за период с 2002 по 2013 гг. приведена в табл. 1.10.

Таблииа 1.10

Структура видов потерь при добыче и комплексной переработке, \%

\begin{tabular}{|l|c|c|c|c|c|c|c|}
\hline \multicolumn{1}{|c|}{ Показатель } & Свинец & Цинк & Медь & Кадмий & Золото & Серебро & Сера \\
\hline $\begin{array}{l}\text { Извлечение } \\
\text { полезного } \\
\begin{array}{l}\text { ископаемого в } \\
\text { продукт }\end{array}\end{array}$ & 65,5 & 63,3 & 52,5 & 63,2 & 56,4 & 68,3 & 28,4 \\
\hline $\begin{array}{l}\text { Структура потерь } \\
\text { добыча }\end{array}$ & 25,0 & 23,0 & 16,6 & 24,2 & 11,4 & 17,4 & 14,0 \\
\hline обогащение & 64,3 & 61,5 & 42,3 & 39,6 & 76,4 & 69,6 & 62,9 \\
\hline \multicolumn{1}{|c}{ металлургия } & 10,7 & 15,5 & 41,1 & 36,2 & 12,2 & 13,0 & 23,1 \\
\hline
\end{tabular}

Примечание. Сера - попутный продукт. Источник: [12].

Таким образом, увеличение роста добычи минерального сырья зависит от МСБ, которая определяется содержанием полезных компонентов в сырье и рентабельностью их промышленной разработки. Другими факторами роста добычи и переработки многокомпонентных руд являются внедрение новых технологий добычи, которые могут обеспечить перевод прогнозных ресурсов в промышленные запасы, и новых технологий переработки минерального сырья, а также снижение технологических потерь, что связано с увеличением налогового потенциала по НДПИ.

\subsection{2. Предложения по установлению дифференцированных ставок по налогу на добычу полезных ископаемых для твердых полезных ископаемых при добыче многокомпонентных руд}

Из-за поликомпонентной структуры ТПИ и высоких потерь при их добыче и обогащении, приводящих к уменьшению налоговой базы по НДПИ, возникает необходимость разработки новых подходов к дифференцированному налогообложению в этой сфере экономической деятельности. При этом, по нашему мнению, извлечение полезных компонентов в готовую продукцию относится к числу рентообразующих факторов и должно включаться в модель определения дифференцированных ставок и налогового потенциала по НДПИ при налогообложении ТПИ, добытых из техногенных и природных месторождений.

Анализ состояния налогообложения горнодобывающих предприятий показал, что до настоящего времени определение дифференцированных ставок по НДПИ и налогового потенциала по НДПИ для полезных ископаемых, извлеченных из минерального сырья (природных и техногенных месторождений), не являлось результатом решения оптимизационных задач. Такой подход позволил бы определить дифференцированные ставки и 
налоговый потенциал по НДПИ и получить дополнительные источники налоговых поступлений в бюджеты бюджетной системы Российской Федерации. При формировании налоговой базы по НДПИ не учитывается отраслевая специфика добычи полезных ископаемых, недостаточно рассмотрены проблемные вопросы, связанные с нормированием потерь полезных ископаемых на стадиях добычи и комплексной переработки минерального сырья.

Плоская шкала действующего НДПИ не позволяет проводить дифференциацию его взимания в зависимости от стадий освоения, горногеологических условий, степени выработанности и местоположения месторождения, что создает неравные условия для добывающих организаций. Добыча полезных ископаемых при значительных эксплуатационных затратах становится для недропользователей нецелесообразной (отрицательный показатель экономической эффективности проекта разработки месторождения), a у государства (собственника недр) увеличивается число нерентабельных месторождений.

Дифференцированные ставки по НДПИ оказывают непосредственное влияние на показатели чистой дисконтированной стоимости ( $N P V)$, внутренней нормы доходности $(I R R)$. Применение плоской шкалы приводит к тому, что в разряд нерентабельных попадают месторождения, где $N P V$ равен нулю, хотя при снижении налоговых ставок по НДПИ разработка последних может стать экономически целесообразной.

Факты, изложенные в подразделе 1.3.1, дают основание полагать, что на данном этапе становления налоговых отношений в России и при существующем уровне развития высоких технологий оценка минерального сырья неадекватна. Цены на рынке минерального сырья могут искажать истинную ценность полезных компонентов, поскольку зачастую не отражают реальной экономической выгоды от комплексного использования полезных ископаемых.

Образование дифференциальной ренты связано в первую очередь с конкретным месторождением, которое имеет геолого-экономическую оценку разведанных запасов и утвержденную технологию добычи. К геолого-экономической оценке в качестве рентообразующего фактора относится содержание полезного компонента в исходном минеральном сырье, а к технологии добычи - извлечение полезных компонентов в готовую продукцию. Вопрос, какой из показателей должен быть принят для целей определения дифференцированных ставок по НДПИ, относится к одному из самых обсуждаемых.

Соответствующие ограничения будут приняты на основе анализа указанного показателя для отрасли, исходя из технологического регламента комплексной переработки видов минерального сырья для каждого полезного ископаемого и/или полезного компонента, либо на основе анализа показателей, закрепленных в технико-экономическом обосновании временных и/или постоянных кондиций промышленных запасов полезных ископаемых.

До настоящего времени в нормативных правовых актах, регламентирующих деятельность предприятий горнодобывающего комплекса, не определено, что именно является подтверждением коммерческой целесообразности инвестиционных проектов: 1) утверждение временных кондиций промышленных запасов; 2) утверждение постоянных кондиций промышленных запасов; 3) факт реализации товарной продукции; 4) иные критерии. 
Если основные рентообразующие факторы - содержание полезного компонента в исходном твердом полезном ископаемом, извлечение полезного компонента в готовую и/или товарную продукцию - не подтверждают техникоэкономическое обоснование временных кондиций промышленных запасов ТПИ, то, соответственно, отсутствует и коммерческая целесообразность реализации такого проекта освоения месторождения полезных ископаемых. В России эти факторы рассматриваются как основные показатели эффективности комплексной переработки ТПИ.

Таким образом, критериями изъятия НДПИ могут выступать дифференциальная рента I и дифференциальная рента II. В целях определения горной ренты и ренты комплексной переработки должны учитываться свойства конкретной продукции по видам полезных ископаемых.

Так как развитие концепции рентного налогообложения в налоговой системе Российской Федерации не выделено, предлагается в целях совершенствования налогообложения ТПИ считать критериями дифференциации ставок НДПИ для ТПИ следующие факторы: содержание полезного компонента в минеральном сырье, которое является исходным при вовлечении его в переработку, и величину извлечения полезного компонента в товарную продукцию - химически чистый металл. Список рентообразующих факторов для природных месторождений, помимо вышеуказанных, целесообразно расширять. Для техногенных месторождений они могут являться исчерпывающими на данной стадии определения дифференцированных подходов к налогообложению такого сырья на основе рентных принципов. Эти показатели позволят дифференцировать ставки НДПИ и будут контролируемыми с точки зрения соблюдения налогового законодательства, если их закрепить в технико-экономическом обосновании при постановке промышленных запасов (A, В) ТПИ на государственный баланс и обосновании технологии извлечения, утвержденной в законодательном порядке. Для техногенных месторождений, запасы которых не суммируются с природными запасами при постановке на государственный баланс, данные рентообразующие факторы предлагается указывать в кадастре техногенных месторождений.

Правительство Российской Федерации в целом поддерживает идею установления дифференцированного налогообложения по НДПИ, которое будет стимулировать разработку более сложных и менее доступных месторождений, в том числе месторождений ТПИ с более бедными рудами, а также ТМ. Определение дифференцированных ставок по НДПИ для ТПИ может быть основано на установлении налоговой ставки для каждого полезного компонента, находящегося в минеральном сырье и показывающего целесообразность реализации инвестиционных проектов по каждому месторождению, включая ТМ. Следует осуществлять выборку инвестиционных проектов, которые будут участвовать в расчетах по определению дифференцированных ставок и налогового потенциала по НДПИ. Выборка будет зависеть от постановки задачи по определению ставок и величины потенциала НДПИ. При расширении рентных принципов налогообложения выборка портфеля инвестиционных проектов для техногенных месторождений может быть различной в зависимости от мест скопления / нахождения ТМ. 


\subsection{3. Модель расчета дифреренцированных ставок по налогу на добычу полезных ископаемых для многокомпонентного природного и техногенного минерального сырья}

Выше отмечено, что при добыче и комплексной переработке минерального сырья не происходит полного извлечения всех видов полезных ископаемых при существующих промышленных технологиях. Эксплуатационные и технологические потери полезных компонентов составляют около 40 \%, что приводит к снижению налоговых поступлений от организаций МСК. Эксперты отмечают, что действующая система налогообложения природопользования не стимулирует недропользователей к проведению геологоразведочных работ для поиска пригодных к разработке новых площадей, а также не способствует разработке техногенных месторождений и полномасштабному проведению природоохранных мероприятий.

Недропользователи и ответственные ведомства предлагают к действующей формуле расчета НДПИ применять коэффициенты, которые учитывают горно-геологические и экономические факторы, географические и иные условия разработки месторождений, степень их выработанности (истощенности). Введение дифференцированных ставок должно быть направлено на стимулирование разработки малорентабельных месторождений, а также должно способствовать установлению одинаковых условий для недропользователей, которые разрабатывают месторождения с различной степенью доступности и различным содержанием полезных компонентов в минеральном сырье («богатством»).

Однако идея установления дифференцированных подходов к изъятию налогов, несмотря на ее обоснованность, затруднительна в силу того, что каждое месторождение обладает уникальными геологическими и техническими характеристиками. Так как в Налоговом кодексе Российской Федерации закреплены все необходимые для расчета налогов элементы, введение дифференцированных ставок по НДПИ потребует реформирования законодательной базы по налогам и сборам и выработки унифицированных для предприятий горнодобывающего комплекса критериев дифференциации и определения налогового потенциала.

Ниже предлагается модель расчета дифференцированных налоговых ставок по НДПИ для ТМ.

Для расчета введем обозначения: $M$ - число рассматриваемых ТМ, единиц; $r_{m}$ - минимальная ставка доходности, при которой реализуется проект по разработке $m$-го ТМ, \%; $K$ - количество различных полезных компонентов в рассматриваемых $\mathrm{TM}$, единиц; $t_{m}-$ срок инвестиционного проекта по разработке $m$-го ТМ, лет; $c_{m t}$ общая сумма затрат на инвестиционный проект $m$ в год $t$, млн руб.; $q_{m t k}-$ получение готовой продукции в весовом выражении (как произведение добытой массы минерального сырья, содержания полезного компонента (г/т) в этой добытой массе и сквозного извлечения $k$-го компонента на месторождении $m$ в год $t$ согласно принятой технологии разработки ТМ), т; $p_{t k}$ - прогнозируемая рыночная цена компонента $k$ в год $t$, руб/т; $\eta_{k}$ - ставка НДПИ для $k$-го полезного компонента, $\% ; d_{t}-$ ставка дисконтирования на срок $t$ лет [11].

Ставка дисконтирования может определяться как бескупонная ставка доходности по государственным облигациям, полученная из $G$-кривой [60]. Для 
разработки моделей введем, базируясь на функции Хевисайда, следующую индикаторную функцию $F(x)$, выраженную соотношением:

$$
F(x)=\left\{\begin{array}{l}
0, x<0 \\
1, x \geq 0
\end{array} .\right.
$$

Предположим, что инвестиционный проект по разработке $m$-го ТМ будет реализовываться, если ставка IRR будет не ниже, чем минимальная ставка доходности $\left(r_{m}\right)$. Или, что то же самое, $N P V$ инвестиционного проекта, рассчитанной по ставке $r_{m}$, будет больше либо равен нулю. В случае если НДПИ исчисляется от величины выручки при реализации (продаже) соответствующего полезного ископаемого и/или компонента, условие реализации инвестиционного проекта по разработке $m$-го месторождения выражается условием:

$$
\mathrm{NPV}_{m}\left(r_{m}\right)=\sum_{t=1}^{t_{m}} \frac{\sum_{k=1}^{K}\left(\left(1-\eta_{k}\right) q_{m t k} p_{t k}\right)-c_{m t}}{\left(1+r_{m}\right)^{t}} \geq 0 .
$$

Рассмотрим более подробно правую часть формулы (1.2). Произведение ( $q_{m t k}$ $p_{t k}$ ) дает выручку от продажи $k$-го полезного ископаемого и/или компонента, извлеченного из $m$-го месторождения в год $t$. Соответственно, $\left(1-\eta_{k}\right) q_{m t k} p_{t k}-$ экономические выгоды после налогообложения НДПИ по $k$-му полезному ископаемого и/или полезному компоненту. Числитель выражения (1.2) - это результаты разработки ТМ $m$ после уплаты НДПИ по всем полезным ископаемым и/или компонентам в год $t$. Дисконтирование данных величин осуществляется по ставке доходности $r_{m}$, достижение которой может обеспечить реализацию инвестиционного проекта по разработке $m$-го ТМ. При таких параметрах месторождения выполнение выражения (1.2) зависит от дифференцированных ставок НДПИ.

Налоговый потенциал по НДПИ от вовлечения в разработку ТМ (инвестиционных проектов) оценивается как приведенная стоимость налоговых поступлений по НДПИ в соответствии с формулой:

$$
\mathrm{NPV}_{\mathrm{TM}}\left(\eta_{k}, k=1, \ldots K\right)=\sum_{t=1}^{\max \left(t_{m}, m=1, \ldots M\right)} \frac{\sum_{m=1}^{M} F\left(N P V_{m}\left(r_{m}\right)\right) \sum_{k=1}^{K} \eta_{k} q_{m t k} p_{t k}}{\left(1+d_{t}\right)^{t}} .
$$

$F\left(N P V_{m}\left(r_{m}\right)\right)=1$, если $m$-е ТМ (инвестиционный проект) разрабатывается, в противном случае $F\left(N P V_{m}\left(r_{m}\right)\right)=0$. Произведение $\eta_{k} q_{m t k} p_{t k}$ будет равняться поступлениям налога на добычу полезных ископаемых в бюджетную систему в год $t$ от разработки ТМ $m$ твердого полезного ископаемого (в случае его разработки) [11].

Для расчета стоимости будущих налоговых платежей по НДПИ осуществляется дисконтирование на основании ставок доходности государственных облигаций Российской Федерации, представленных в виде $G$-кривой. Для нахождения адвалорных дифферениированных ставок НДПИ, где за основу формирования налоговой базы по НДПИ приняты рыночные цены на товарную продукцию, обеспечивающие разработку низкорентабельных техногенных 
месторождений и максимальный налоговый потенциал по НДПИ, целесообразно решить оптимизационную задачу:

$$
\begin{gathered}
\max \sum_{t=1} \frac{\sum_{m=1}^{M} F\left(N P V_{m}\left(r_{m}\right)\right) \sum_{k=1}^{K} \eta_{k} q_{m t k} p_{t k}}{\left(1+d_{t}\right)^{t}}, \\
\eta_{k}, k=1, \ldots K \\
\eta_{k} \geq \eta_{k}^{*}, k=1, \ldots K,
\end{gathered}
$$

где $\eta^{*} k, k=1 \ldots K-$ минимальные значения ставок НДПИ по соответствующим компонентам.

В частном случае все или некоторые из величин $\eta^{*} k, k=1 \ldots K$ могут оказаться отрицательными, тогда и соответствующие налоговые ставки НДПИ $\eta_{k}, k=$ $1 \ldots K$ в результате решения задачи (1.4) могут получиться меньше нуля. Если в рассматриваемой модели получен результат с отрицательной ставкой НДПИ по некоторым полезным компонентам, то необходимо предоставлять субсидии или иные преференции и льготы со стороны государства в рамках действующего законодательства Российской Федерации о налогах и сборах. Возможность субсидий предусматривается, например, Распоряжением Правительства РФ от 9 декабря 2014 г. № 1339 (с изменениями и дополнениями).

\section{4. Формирование системы кадастров и баз данных техногенных месторождений}

\subsection{1. Проблемы и задачи кадастровой оценки техногенных минеральных объектов}

В 2002 г. постановлением Межпарламентской Ассамблеи государств участников СНГ был принят Модельный кодекс «О недрах и недропользовании» для государств - участников $\mathrm{CH} \Gamma^{24}$, статья 38 которого предусматривает создание Государственного кадастра техногенных месторождений в дополнение к Государственному кадастру месторождений. В соответствие с указанной статьей кадастр ТМ должен содержать сведения: о пространственном местонахождении ТМ; занимаемом им объеме (площади); количестве и качестве полезных ископаемых в нем; содержащихся полезных компонентах и характере их распределения (концентрации); степени изученности и достоверности полученных данных; горнотехнических, гидрогеологических, экономических и иных условиях разработки; геолого-экономической оценке ТМ; иных характеристиках и параметрах ТМ.

Отметим, что Модельный кодекс, в отличие от Закона РФ «О недрах», содержит и раскрывает понятие ТМ минерального сырья (ст. 246). Однако его положения для российского законодательства о недрах не являются юридически обязывающими. Это законодательный акт типового характера, содержащий рекомендации национальным законодательствам государств - участников СНГ. Отдельные модельные нормы входят в противоречие с базовыми положениями

\footnotetext{
${ }^{24}$ Модельный кодекс о недрах и недропользовании для государств - участников СНГ: принят постановлением Межпарламентской Ассамблеи государств - участников СНГ от 7 декабря 2002 г. № 20-8 // ГАРАНТ.PУ: официал. интернет-портал. URL: http://base.garant.ru/2568378/ (дата обращения: 21.09.2019).
} 
российского законодательства. Например, Модельный кодекс признает право собственности на отходы первичной переработки минерального сырья, находящегося в пределах горного отвода, за владельцами лицензий на время их действия (ст. 252), в то время как Закон РФ «О недрах» считает отходы первичной переработки государственной собственностью (ст. 6). Некоторые страны СНГ, такие как Казахстан, реализовали положения Модельного кодекса в отношении техногенных минеральных образований, и недропользователь как собственник отходов добычи и переработки полезных ископаемых может совершать с ними гражданско-правовые сделки.

В Российской Федерации, несмотря на огромное количество накопленных и ежегодно образующихся отходов горного производства, отсутствует единая база данных о техногенных минеральных образованиях (техногенных месторождениях и техногенных образованиях, не имеющих статуса месторождения). Государственная политика недропользования в этом отношении направлена на то, чтобы передать право создания баз данных ТMO и разработку кадастров техногенных месторождений на региональный уровень. Статья 20 Федерального закона «Об отходах производства и потребления» гласит, что органы исполнительной власти субъектов РФ вправе вести региональные кадастры отходов.

Последовательно и на научной основе работа по систематизации ТМО ведется в Мурманской и Свердловской областях как в развитых горнодобывающих регионах России. В 2003 г. Г.Г. Хасанова обосновала научно-методические принципы кадастровой (прогнозной) оценки ТМО Среднего Урала на основе формирования и анализа региональной информационной базы техногенных образований этого старейшего региона добычи полезных ископаемых. Кадастровая оценка ТМО рассматривалась автором как часть предварительного этапа разработки долгосрочной стратегии изучения, геолого-технологической и экологоэкономической оценки техногенных объектов и реализации проектов утилизации ГПО в Уральском регионе [138]. Импульсом стала специальная федеральная и областная программа переработки техногенных образований Свердловской области, принятая в 1996 г.

В настоящее время работа по созданию региональных кадастров ТМО продолжается и получает новое развитие в свете экологизации горнодобывающих производств на основе внедрения НДТ. Новый порядок взимания платы за НВОС распространяется на опасные ГПО, стимулируя комплексное использование минерального сырья, наращивание процесса утилизации образуемых техногенных отходов и проведение инвентаризации существующих ТМО. Основными целями кадастровой оценки являются: формирование региональной базы данных о скоплениях техногенного сырья, предварительное ранжирование ТМО по степени их изученности и ресурсной ценности, первичная оценка воздействия ТМО как объектов размещения ГПО на ОС.

Методическая направленность кадастровой оценки ТМО должна быть ориентирована на решение следующих основных задач ${ }^{25}:$ 1) формирование уточненной региональной информационной базы данных по техногенным

25 Хасанова Г. Г. Основные задачи кадастровой оценки техногенных месторождений // Геология, полезные ископаемые и проблемы геоэкологии Башкортостана: сб. ст. конф. (Уфа, 21-23 мая 2018 г.). С. 361-362 // Институт геологии УФИЦ РAH: сайт. URL: http://ig.ufaras.ru/File/conf2018/Conf_2018_63.pdf (дата обращения: 21.10.2019). 
минеральным объектам с помощью сбора и систематизации всех имеющихся архивных, фондовых, опубликованных материалов и отчетных сведений предприятий и других организаций; 2) разработка классификации техногенных месторождений, составление карт и схем их территориального размещения; 3) разработка, внедрение и совершенствование существующей системы паспортного учета техногенных объектов с составлением территориального кадастра техногенных месторождений; 4) обоснование принципов ранжирования техногенных объектов по их ресурсной ценности и экологической опасности; 5) анализ современного состояния МСБ техногенных образований региона с оценкой степени их геолого-технологической и эколого-экономической изученности, с определением направлений промышленного использования и возможной инвестиционной привлекательности; 6) разработка рекомендаций по методике доизучения и последующей системной оценке техногенных месторождений; 7) типизация техногенных месторождений с возможным выделением геолого-промышленных типов.

Структура кадастра ТМО и характер решаемых с его помощью задач нормативно не установлены и определяются многими факторами, такими как цели прикладных исследований, виды добываемых полезных ископаемых, степень воздействия на ОС и т. д. Так, например, одной из целей изучения кадастровой информации может быть определение элементов дифференцированного налогообложения по НДПИ в зависимости от видов полезных ископаемых при добыче поликомпонентных руд и комплексном использовании минерального сырья.

T. А. Блошенко показала [12], что для перехода на налогообложение по НДПИ, стимулирующее комплексную переработку природного и техногенного минерального сырья, необходимо применить модели определения дифференцированных адвалорных ставок и налогового потенциала по НДПИ по видам и компонентам полезных ископаемых. Это, в свою очередь, требует определенным образом структурировать и систематизировать информацию по всему массиву параметров, достоверно описанных в системе кадастров ТМО. Государственный кадастр месторождений полезных ископаемых не предоставляет таких возможностей с учетом объема требуемых данных и их доступности.

Характеристики и показатели кадастра ТМ необходимо актуализировать на определенном временном горизонте, а также обновлять с учетом развития науки и технологий, изменений рыночной конъюнктуры, поступлений новых данных о минералогическом опробовании (изменений минералогического состава сырья). В кадастр могут вноситься изменения по представлениям пользователей кадастра, министерств, ведомств, проектных организаций, отраслевых научноисследовательских институтов. Кадастровый учет должен строиться на объективных данных первичной документации, которая имеется в организациях, а также использовать данные статистической отчетности, результаты работы проектных и научных организаций, технико-экономических расчетов и прочую необходимую информацию.

\subsection{2. Методические подходы к созданию кадастра горнопромышленных отходов в Мурманской области}

Рациональное использование ГПО как вторичных минерально-сырьевых ресурсов является одной из наиболее актуальных экономических и экологических проблем в регионах Севера и Арктики, в частности в Мурманской области. На eе 
территории действуют крупные горно-обогатительные и горно-металлургические предприятия, являющиеся градообразующими для городов Кировска и Апатиты (АО «Апатит», АО «Северо-Западная фосфорная компания (СЗФК)»), Заполярного, п. Никеля, городов Мончегорска (АО «Кольская ГМК»), Оленегорска (АО «Олкон»), Ковдора (АО «Ковдорский ГОК»), п. Ревды (ООО «Ловозерский горнообогатительный комбинат»), в которых проживает более трети населения области.

В этих городах-сателлитах горнодобывающие и металлургические предприятия являются основными источниками формирования доходной части областного и районных бюджетов [76]. В то же время на вышеперечисленных предприятиях образуется огромное количество ГПО - потенциальных вторичных минерально-сырьевых ресурсов. В качестве примера на рис.1.2 приведена схема образования отходов на АО «Ковдорский ГОК» [47].

В соответствии с приведенными в табл. 1.11 данными, на территории Мурманской области расположено шестнадцать крупных хвостохранилищ площадью от десятков до нескольких тысяч гектаров, из которых восемь (50 \%) законсервированы: шесть - по заполнению и два (хвостохранилище обогатительной фабрики рудника «Умбозеро» и хвостохранилище вермикулитовой обогатительной фабрики комбината «Ковдорслюда») - по причине остановки и консервации рудников. Хвостовые отложения представляют собой мелкодисперсный песок, содержащий соответствующие эксплуатируемому месторождению полезные ископаемые в количестве, представляющем в большинстве случаев промышленный интерес [4]. Горный институт КНЦ РАН осуществляет учет и регулярно пополняет данные по накоплению ГПО на горнодобывающих и перерабатывающих предприятиях Кольского региона, осуществляет анализ их количества и динамики накопления [29].

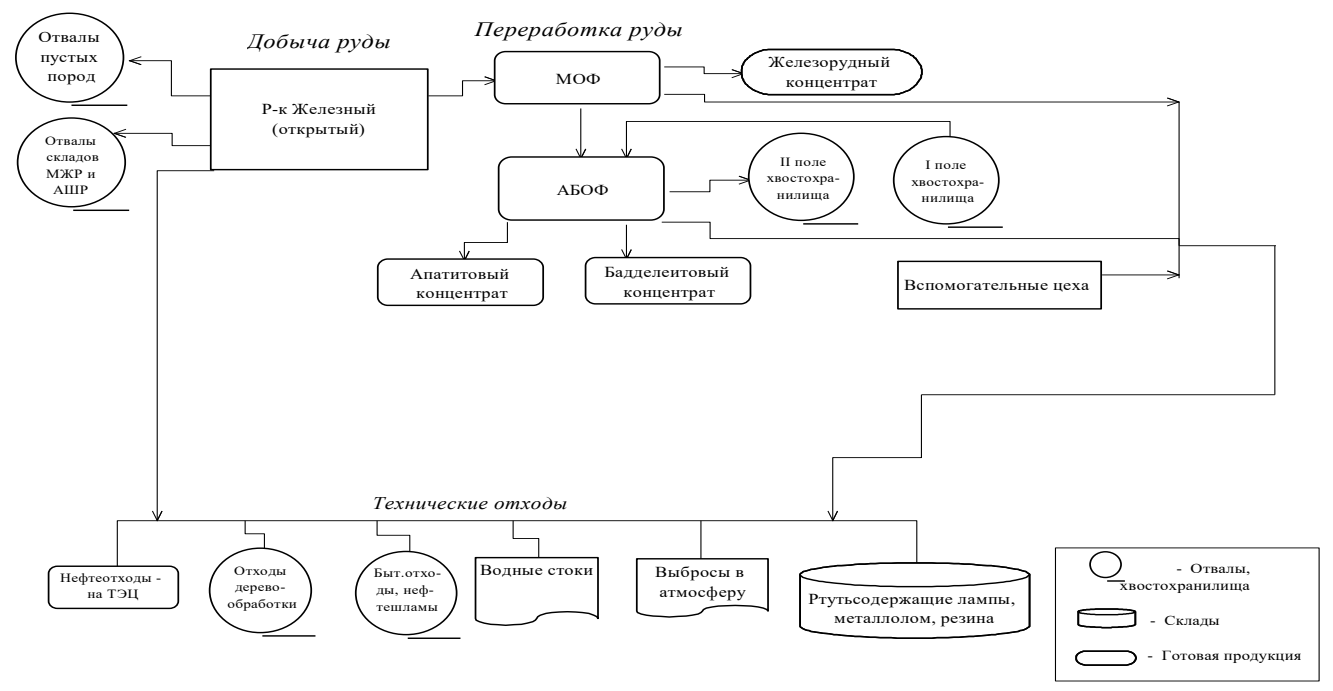

Рис. 1.2. Схема образования ГПО на АО «Ковдорский ГОК»:

МОФ — магнитная обогатительная фабрика; АБОФ — апатит-баддеилитовая обогатительная фабрика 
Таблица1.11

Основные характеристики хвостохранилищ Мурманской области [4]

\begin{tabular}{|c|c|c|c|c|c|}
\hline \multirow[t]{2}{*}{ Хвостохранилище } & \multicolumn{2}{|c|}{ Время заполнения } & \multirow{2}{*}{$\begin{array}{c}\text { Название и } \\
\text { крупность } \\
\text { хвостов, мм }\end{array}$} & \multirow{2}{*}{$\begin{array}{l}\text { Занимаемая } \\
\text { площадь, га }\end{array}$} & \multirow{2}{*}{$\begin{array}{c}\text { Полезные } \\
\text { ископаемые в } \\
\text { отходах }\end{array}$} \\
\hline & начало & конец & & & \\
\hline \multicolumn{6}{|c|}{$A O$ «Кольская ГМК» } \\
\hline $\begin{array}{l}\text { ОФ-1 } \\
\text { «Печенганикель» } \\
\text { поле } 1\end{array}$ & 1965 г. & 1974 г. & Песок до 0,1 & 1050 & $\mathrm{Ni}, \mathrm{Cu}, \mathrm{Co}$ \\
\hline поле 2 & 1974 г. & $\begin{array}{l}\text { Действую } \\
\text { щее }\end{array}$ & То же & 1050 & $\mathrm{Ni}, \mathrm{Cu}, \mathrm{Co}$ \\
\hline ОФ-2 & 1945 г. & 1994 г. & $\gg$ & Н. д. & $\mathrm{Ni}, \mathrm{Cu}, \mathrm{Co}$ \\
\hline Плавцех & 1945 г. & $\begin{array}{l}\text { Действую } \\
\text { щее }\end{array}$ & $\begin{array}{l}\text { Гранулирован } \\
\text { ный шлак до } \\
2,5\end{array}$ & 86 & $\mathrm{Ni}, \mathrm{Cu}, \mathrm{Co}$ \\
\hline Мончегорская ОФ & 1935 г. & 1978 г. & Песок до 1,0 & Н. д. & $\mathrm{Ni}, \mathrm{Cu}, \mathrm{Co}$ \\
\hline \multicolumn{6}{|c|}{ ООО «Ловозерский ГОК» } \\
\hline $\begin{array}{c}\text { ОФ «Карнасурт» } \\
\text { поле } 1\end{array}$ & 1951 г. & 1987 г. & Песок до 1,0 & 60 & $\begin{array}{l}\mathrm{Nb}_{2} \mathrm{O}_{5}, \mathrm{Na}_{2} \mathrm{O} \\
\mathrm{K}_{2} \mathrm{O}\end{array}$ \\
\hline поле 2 & 1987 г. & $\begin{array}{l}\text { Действую } \\
\text { щее }\end{array}$ & То же & 380 & $\begin{array}{l}\mathrm{Nb}_{2} \mathrm{O}_{5}, \mathrm{Na}_{2} \mathrm{O}, \\
\mathrm{K}_{2} \mathrm{O}\end{array}$ \\
\hline ОФ «Умбозеро» & 1984 г. & $\begin{array}{l}\text { Законсерв } \\
\text { ировано }\end{array}$ & $\gg$ & 13,5 & $\begin{array}{l}\mathrm{Nb}_{2} \mathrm{O}_{5}, \mathrm{Na}_{2} \mathrm{O}, \\
\mathrm{K}_{2} \mathrm{O}\end{array}$ \\
\hline \multicolumn{6}{|c|}{$A O « O Л К O H »$} \\
\hline $\begin{array}{c}\text { Дробильная ОФ } \\
\text { основное }\end{array}$ & 1954 г. & $\begin{array}{l}\text { Действую } \\
\text { щее }\end{array}$ & Песок до 1,6 & 1087 & $\mathrm{Fe}_{2} \mathrm{O}_{3}$ \\
\hline аварийное & 1954 г. & То же & То же & 320,4 & $\mathrm{Fe}_{2} \mathrm{O}_{3}$ \\
\hline \multicolumn{6}{|c|}{$A O$ «Ковдорский ГОК» } \\
\hline $\begin{array}{l}\text { Магнитная ОФ } \\
\text { поле } 1\end{array}$ & 1962 г. & 1981 г. & Песок до 2,5 & 293,7 & $\begin{array}{l}\mathrm{P}_{2} \mathrm{O}_{5}, \mathrm{ZrO}_{2}, \\
\mathrm{MgO}, \mathrm{CaO}\end{array}$ \\
\hline поле 2 & 1981 г. & $\begin{array}{l}\text { Действую } \\
\text { щее }\end{array}$ & Песок до 1,25 & 1030 & $\begin{array}{l}\mathrm{P}_{2} \mathrm{O}_{5}, \mathrm{ZrO}_{2}, \\
\mathrm{MgO}, \mathrm{CaO}\end{array}$ \\
\hline \multicolumn{6}{|c|}{$A O \ll$ Аnamum» } \\
\hline АНОФ-1 (16 км) & 1957 г. & 1963 г. & Песок до 0,02 & 120 & $\begin{array}{l}\mathrm{P}_{2} \mathrm{O}_{5}, \mathrm{TiO}_{2}, \\
\mathrm{Al}_{2} \mathrm{O}_{3}\end{array}$ \\
\hline АНОФ-2 & 1968 г. & $\begin{array}{l}\text { Действую } \\
\text { щее }\end{array}$ & Песок до 0,25 & 1653 & $\begin{array}{l}\mathrm{P}_{2} \mathrm{O}_{5}, \mathrm{TiO}_{2}, \\
\mathrm{Al}_{2} \mathrm{O}_{3}\end{array}$ \\
\hline АНОФ-3 & 1963 г. & То же & То же & 1248,7 & $\begin{array}{l}\mathrm{P}_{2} \mathrm{O}_{5}, \mathrm{TiO}_{2}, \\
\mathrm{Al}_{2} \mathrm{O}_{3}\end{array}$ \\
\hline \multicolumn{6}{|c|}{ ООО «Ковдорслюда» } \\
\hline $\begin{array}{l}\text { Вермикулитовая } \\
\text { ОФ }\end{array}$ & 1955 г. & $\begin{array}{l}\text { Законсерв } \\
\text { ировано }\end{array}$ & $\begin{array}{l}\text { Песок, гравий } \\
\text { до 5,0 }\end{array}$ & 35 & $\begin{array}{l}\text { Оливин, } \\
\text { вермикулит, } \\
\text { диобсид } \\
\end{array}$ \\
\hline
\end{tabular}


Наряду с учетом отвалов пустых горных пород, отдельного внимания требуют крупномасштабные хвостохранилища, представляющие собой специально созданные накопители жидких ГПО (табл. 1.11). На рис.1.3 показана динамика сброса жидких ГПО (хвосты обогатительных фабрик) в хвостохранилища на территории Мурманской области [76]. Видно, что общее количество отходов обогащения превысило 2,1 млрд т, а ежегодно в хвостохранилища региона помещается более 35 млн т хвостов обогатительных фабрик.

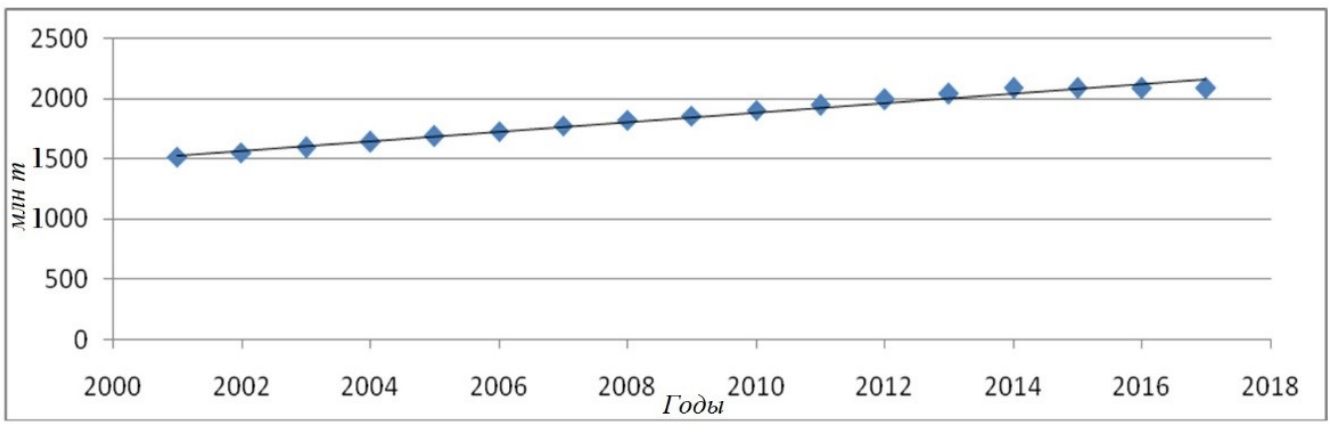

Рис. 1.3. Динамика накопления отходов обогащения в хвостохранилищах Мурманской области

Вследствие интенсивного недропользования на протяжении более восьмидесяти лет на Кольском полуострове накоплено свыше 6 млрд т ГПО, что привело к значительному изменению рельефа региона. Появились техногенные горы из отвалов пород высотой до 60 м и длиной в несколько километров; созданы хвостои шламохранилища площадью в несколько тысяч гектаров и высотой ограждающих дамб до 50 м; в окрестностях горнодобывающих и перерабатывающих производств произошла существенная деградация окружающей природной среды, изменился гидрогеологический режим $[75,76]$. Из-за непрерывного прироста объема накопления ГПО (свыше 35 млн т в год) усиливается их НВОС, что повышает актуальность проблемы управления отходами в целях обеспечения устойчивого развития Мурманской области и природных экосистем региона.

Рациональное использование минерально-сырьевых ресурсов - это процесс сбалансированных экономических и социальных изменений, при котором эксплуатация природных ресурсов, включая использование ГПО как вторичного минерального сырья, сохранение ОС, промышленная и экологическая безопасность системно согласованы и укрепляют на основе привлечения инвестиций нынешний и будущий природно-ресурсный потенциал региона [107]. Одним из факторов рационального использования отходов добычи, первичной переработки и обработки минерального сырья является создание кадастра горнопромышиенных отходов, включающего систематизированный свод сведений об отходах основного и вспомогательного производств, описания их качественных и количественных характеристик, местоположения, отображенного на картосхемах, степени опасности (токсичности), промышленной ценности. 
Раздел I. Общие сведения

\begin{tabular}{|c|c|c|c|c|c|c|}
\hline & \multicolumn{2}{|c|}{ Наименование территории } & \multicolumn{5}{|c|}{ Характеристика объекта учета } \\
\hline $\begin{array}{c}\text { № } \\
\text { п/п }\end{array}$ & $\begin{array}{c}\text { Административный } \\
\text { район }\end{array}$ & $\begin{array}{c}\text { Экономический } \\
\text { район }\end{array}$ & $\begin{array}{c}\text { Наименование } \\
\text { предприятия }\end{array}$ & Отрасль & $\begin{array}{c}\text { Наименование } \\
\text { отхода }\end{array}$ & $\begin{array}{c}\text { Технологический } \\
\text { процесс по образованию } \\
\text { отхода } \\
\text { владения, управления } \\
\text { отходами }\end{array}$ \\
\hline & 2 & 3 & 4 & 5 & 6 & 7 \\
\hline
\end{tabular}

Таблииа 1.13

Раздел II. Количественно-оценочная характеристика отходов

\begin{tabular}{|c|c|c|c|c|c|}
\hline \multirow{2}{*}{$\begin{array}{c}\text { Наименование отхода } \\
\text { с указанием: } \\
\text { накопленные, текущего } \\
\text { производства и пр. }\end{array}$} & \multicolumn{3}{|c|}{ Наличие и образование отходов } & \multicolumn{2}{|c|}{ Использование отходов } \\
\hline & $\begin{array}{c}\text { единицы } \\
\text { измерения }\end{array}$ & $\begin{array}{c}\text { наличие отходов в местах } \\
\text { организованного хранения, } \\
\text { складирования }\end{array}$ & $\begin{array}{c}\text { годовое образование } \\
\text { отходов на данном } \\
\text { предприятии }\end{array}$ & $\begin{array}{c}\text { единицы } \\
\text { измерения }\end{array}$ & всего \\
\hline 6 & 9 & 10 & 11 & 12 & 13 \\
\hline \multicolumn{6}{|c|}{ Использование отходов } \\
\hline $\begin{array}{l}\text { Использовано на своем } \\
\text { предприятии }\end{array}$ & \multicolumn{2}{|c|}{$\begin{array}{c}\text { Реализовано другим предприятиям, } \\
\text { организациям }\end{array}$} & \multicolumn{2}{|c|}{$\begin{array}{c}\text { Складируется, хранится на полигонах, } \\
\text { накопителях, хвостохранилищах }\end{array}$} & $\begin{array}{l}\text { Обезврежено, } \\
\text { уничтожено, } \\
\text { захоронено }\end{array}$ \\
\hline 14 & \multicolumn{2}{|r|}{15} & \multicolumn{2}{|l|}{16} & 17 \\
\hline \multirow[t]{2}{*}{$\begin{array}{c}\text { Объем неиспользованных } \\
\text { отходов } \\
\end{array}$} & \multirow{2}{*}{\multicolumn{2}{|c|}{ Степень использования отходов }} & \multicolumn{3}{|c|}{ Ценность отходов, тыс. руб. } \\
\hline & & & \multicolumn{2}{|c|}{ извлекаемая за 1 т $\left(\mathrm{m}^{3}\right)$} & кадастровая \\
\hline 18 & & 19 & \multicolumn{2}{|l|}{20} & 21 \\
\hline
\end{tabular}


Таблица 1.14

Раздел III. Характеристика организованного складирования отходов

\begin{tabular}{|c|c|c|c|c|c|c|c|c|c|c|c|}
\hline \multirow{2}{*}{$\begin{array}{c}\text { Наименование } \\
\text { отхода с } \\
\text { указанием: } \\
\text { накопленные, } \\
\text { текущего } \\
\text { производства } \\
\text { и пр. }\end{array}$} & \multirow{2}{*}{\multicolumn{2}{|c|}{$\begin{array}{c}\text { Наименование } \\
\text { накопителя, в } \\
\text { который } \\
\text { поступают } \\
\text { отходы с } \\
\text { данного } \\
\text { предприятия }\end{array}$}} & \multirow[t]{2}{*}{$\begin{array}{l}\text { Местополо } \\
\text { жение } \\
\text { накопителя }\end{array}$} & \multirow{2}{*}{$\begin{array}{c}\text { Расстояние и } \\
\text { способ } \\
\text { транспортировки } \\
\text { отходов от места } \\
\text { образования до } \\
\text { места } \\
\text { накопления, км }\end{array}$} & \multicolumn{2}{|c|}{$\begin{array}{c}\text { Срок службы } \\
\text { (по проекту) } \\
\text { накопителя } \\
\end{array}$} & \multirow{2}{*}{\multicolumn{2}{|c|}{$\begin{array}{c}\text { Мощность } \\
\text { накопителя, } \\
\text { тыс. т (тыс. } \text { м }^{3} \text { ) }\end{array}$}} & \multirow[t]{2}{*}{$\begin{array}{c}\text { Площадь } \\
\text { накопителя, } \\
\text { м }^{2}\end{array}$} & \multirow{2}{*}{$\begin{array}{c}\text { Ежегодное } \\
\text { изменение } \\
(+,-) \\
\text { занятой } \\
\text { земельной } \\
\text { площади, } \\
\text { га } \\
\end{array}$} & \multirow{2}{*}{$\begin{array}{c}\text { Размер } \\
\text { санитарно- } \\
\text { защитной } \\
\text { зоны, км }\end{array}$} \\
\hline & & & & & начало & окончание & & & & & \\
\hline 22 & & & 24 & 25 & 26 & 27 & 28 & & 29 & 30 & 31 \\
\hline \multicolumn{4}{|c|}{ Годовой объем складирования отходов } & \multirow{2}{*}{\multicolumn{2}{|c|}{$\begin{array}{c}\text { Запасы отходов, тыс. т/тыс. } \\
\text { м }^{3}\end{array}$}} & \multirow{2}{*}{\multicolumn{2}{|c|}{\begin{tabular}{|c|} 
Удельные \\
капитальные \\
затраты на хранение \\
отходов, руб/т $\left(\mathrm{m}^{3}\right)$
\end{tabular}}} & \multirow{2}{*}{\multicolumn{2}{|c|}{$\begin{array}{c}\text { Эксплуатационные } \\
\text { затраты на } \\
\text { складирование } 1 \mathrm{~T} \\
\left(\mathrm{M}^{3}\right) \text { отходов, руб/т } \\
\left(\mathrm{M}^{3}\right) \\
\end{array}$}} & \multirow{2}{*}{\multicolumn{2}{|c|}{$\begin{array}{l}\text { Наименование } \\
\text { предприятий, } \\
\text { производящих } \\
\text { ладирование отходов в } \\
\text { данном накопителе }\end{array}$}} \\
\hline \multirow{2}{*}{\multicolumn{2}{|c|}{ единицы измерения }} & \multicolumn{2}{|c|}{ значение } & & & & & & & & \\
\hline & & & 33 & 34 & & 35 & & & 36 & 3 & \\
\hline
\end{tabular}


Опыт Горного института КНЦ РАН по разработке Кадастра отходов горнометаллургического производства Мурманской области [47] в 2000 г. показал, что учету и оценке в кадастре ГПО должны подлежать: отходы горного производства количество и объемы отвалов горных пород; отходы обогащения руд - объемы и характеристики хвостохранилищ; отходы металлургического передела - объемы и характеристики шламохранилищ; отходы обеспечивающих и вспомогательных производств - объемы различного рода складов и отвалов; класс опасности отходов; физико-механическая характеристика параметров отходов; схема их образования; динамика объемов образования и накопления; динамика объемов переработки и утилизации; характеристика местоположений размещения; технико-экономическая оценка промышленной ценности отходов.

Исходя из современных социально-экономических условий и в целях устойчивого развития региона новый кадастр, на наш взгляд, должен быть представлен в виде описаний, блок-схем, специализированных форм-таблиц и картографических материалов; он должен быть унифицированным по стандартам сбора данных, родам классификаций, требованиям режимов использования и переработки (утилизации) отходов, технико-экономической оценки их возможной переработки и утилизации [30]. Ниже представлены фрагменты таблиц трех разделов по заполнению кадастра данными (табл. 1.12-1.14) [47].

Таким образом, региональный кадастр ГПО должен представлять собой специализированную базу данных об отходах горного производства, обогащения руд, металлургического передела, а также об отходах обеспечивающих и вспомогательных производств. Эта база данных должна создаваться посредством систематического сбора, обработки, хранения и обновления качественной и количественной информации об отходах в виде учетностатистических данных, картографических материалов и других документов, получаемых от горнодобывающих и металлургических предприятий региональными органами управления недропользованием и систематизируемых с привлечением специализированных научных организаций ${ }^{26}[29]$.

\subsection{3. Формирование автоматизированной базы данных по техногенному минеральному сырью в Мурманской области}

В Мурманской области наиболее крупными предприятиями горнопромышленного комплекса к настоящему времени добыто около 3,4 млрд т руды, а на ее территории размещено почти 2 млрд т отходов обогащения [16, $21,108]$. Ежегодный прирост таких отходов по Мурманской области в текущем столетии составлял от 38 до 46 млн т и в среднем достигал 70-75\% от объемов добычи руды (табл. 1.15).

${ }^{26}$ Временные правила охраны окружающей среды от отходов производства и потребления в Российской Федерации: утв. Минприроды России 15 июля 1994 г. // Консорциум Кодекс: офиц. интернет-портал. URL: http://docs.cntd.ru/document/902151161 (дата обращения: 10.10 .2019$)$. 
Добыча руды и отходы обогащения наиболее крупных предприятий горнопромышленного комплекса Мурманской области с начала эксплуатации [16]

\begin{tabular}{|l|c|c|}
\hline \multicolumn{1}{|c|}{ Предприятие } & Добыча руды, млн т & Отходы обогащения, млн т \\
\hline $\mathrm{AO}$ «МК Печенганикель» & 365 & 302,5 \\
\hline $\mathrm{AO}$ «Апатит» & 1800 & 910,0 \\
\hline $\mathrm{AO}$ «Ковдорский ГОК» & 580 & 288,2 \\
\hline $\mathrm{AO}$ «Олкон» & 650 & 415,6 \\
\hline $\mathrm{Bceго}$ & 3395 & 1916,3 \\
\hline
\end{tabular}

По ориентировочным оценкам [16], в отходах обогащения горных предприятий Мурманской области находятся запасы: цветных металлов $(\mathrm{Ni}, \mathrm{Cu}$, Со) - 1248 тыс. т, редких металлов (лопарита) - 100,8 тыс. т; железа - 41 млн т, циркония - 0,7 млн т, апатита $\left(\mathrm{P}_{2} \mathrm{O}_{5}\right)-38,5$ млн т, нефелина $\left(\mathrm{Al}_{2} \mathrm{O}_{3}\right)-189,8$ млн т. Кроме того, отходы обогащения апатит-нефелиновых руд содержат другие полезные компоненты $\left(\mathrm{TiO}_{2}\right.$, редкие земли). Эти потенциальные ВМР послужили отправной точкой для формирования АБД по ТМС и горнодобывающим предприятиям Мурманской области, разработка структуры и формирование которой базируется на следующих основных положениях [45, 48]: формирование информационно-логических и физических моделей базы данных на платформе MS Access; использование единых библиотек кодов и классификаторов для идентификации предметной области, отрасли промышленности, наименования предприятия, технологического процесса, формы собственности и др.; использование модулей: для интеграции информации из нескольких источников на предприятии, для оперативной аналитической обработки, для выявления закономерностей на основе выявленных связей в базах данных. Дополнительно учитывались сбор, структурирование и систематизация наиболее полной кадастровой, количественной и качественной информации об объемах, составе, свойствах, опасности объектов складирования, а также направления использования ТМС.

Учету и оценке в АБД по ТМС подлежат: отходы горного производства; отходы обогащения руд; отходы металлургического передела; отходы обеспечивающих и вспомогательных производств; класс опасности отходов; их физико-механическая характеристика; динамика объемов образования и накопления; жидкая фаза отходов, ионный состав с ПДК на них; динамика объемов переработки и утилизации; размещение и др.

В Горном институте КНЦ РАН с 2000 г. создается, постоянно пополняется и обновляется база данных о ТМР Мурманской области. На рис. 1.4 представлена главная кнопочная форма разработанной АБД по ТМС Мурманской области. В настоящее время в базе данных собраны сведения о 41 техногенном минеральносырьевом ресурсе (МСР), размещённом на промплощадках следующих предприятий: АО «Кольская ГМК»: комбинаты «Печенганикель» (шесть МСР) и «Североникель» (два МСР); ООО «Ловозёрский ГОК» (два МСР); АО «Оленегорский ГОК» («Олкон») (шесть МСР); АО «Ковдорский ГОК» (семь $\mathrm{MCP);} \mathrm{АО} \mathrm{«Апатит»} \mathrm{(девять} \mathrm{МСР);} \mathrm{АО} \mathrm{«Ковдорслюда»} \mathrm{(восемь} \mathrm{МСР);} \mathrm{АО}$ «Колэнерго» (один МСР) [4]. 


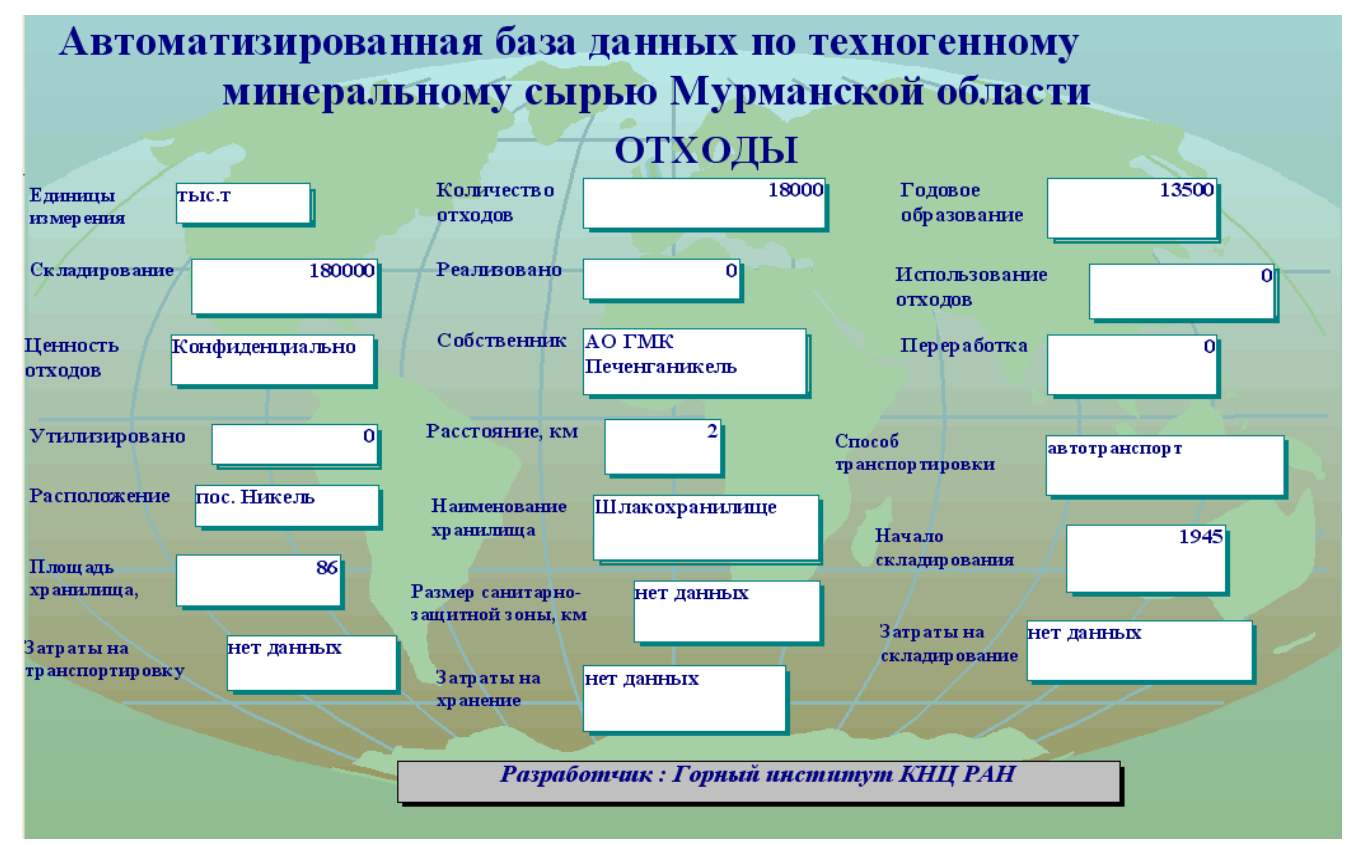

Рис. 1.4. Главная кнопочная форма АБД по ТМС Мурманской области

Как правило, техногенный (вторичный) МСР включает в себя отходы минерального сырья при разработке одного месторождения одним рудником либо отходы обогащения одной обогатительной фабрики. При этом техногенное сырьё состоит из одинаковых типов пород, имеет сходные фазовоминералогический состав, физико-механические свойства и генезис. Например, забалансовые и попутные руды, если они складируются отдельно, образуют и отдельные ТМ, отвалы однотипных пород вскрыши на руднике объединены в одно ТМ, несмотря на разное размещение отвалов на территории рудника. Хвостохранилища, размещённые отдельно, будут представлять собой отдельные ТМ. Породы вскрыши от открытых работ и проходческие породы от подземных работ, складируемые на руднике совместно, объединяются в одно ТМ [4].

База данных включает в себя двадцать одну связанную между собой структурную таблицу, имеющую название, предназначение и содержащую информацию о полях АБД. Мониторинг и пополнение базы данных производится по справкам ГОКов о размещении и накоплении отходов производства в ТM, из опубликованных в печати докладов и статей, по результатам научных исследований Горного института из законченных отчётов, по данным лабораторных и натурных экспериментов института по определению физико-механических и технологических свойств техногенного сырья, а также по мере поступления заключительных отчётов по планам НИР и договорным работам. Мониторинг пополнения техногенного сырья по справкам ГОКов проводится один раз в три года.

Одним из недостатков АБД является неполный объём данных по некоторым предприятиям начиная с 2000 г. С переходом на рыночные отношения часть технических, особенно экономических, показателей перешла в разряд сведений, относящихся к коммерческой тайне. В этой связи пополнение 
АБД за указанный период производится с достаточной регулярностью по ТМ, размещённым на территориях АО «Апатит», АО «Олкон» и АО «Ковдорский ГОК». На этих предприятиях сосредоточено более $75 \%$ всех запасов ТМС в области. По остальным ГМК и ГОКам Мурманской области пополнение АБД осуществляется с меньшей регулярностью [4].

Для накопления, актуализации и пополнения информационных массивов о TMO предлагается создать блок горно-информационной системы «Комплексное освоение техногенного сырья Мурманской области», который будет предназначен для формирования совокупности справочных, аналитических, экспертных и других оценок при решении различных горно-технологических, социально-экономических, управленческих и экологических задач, а также для прогнозирования последствий отработки ТМ, предупреждения возникновения и развития чрезвычайных ситуаций и т. д.

Использование горно-информационной системы «Комплексное освоение техногенного сырья Мурманской области» в целях выработки общей стратегии освоения недр Кольского региона уже на первых этапах разведочных работ обеспечит возможность выполнения поэтапных геолого-экономических оценок горнотехнических возможностей каждого рудного района. Эти оценки позволят уточнять и обосновывать, в частности, объемы увязанных во времени разведочных работ, а также параметры первого и последующих этапов развития будущего предприятия.

\section{Выводы по главе 1}

В современном мире рациональное использование ресурсов недр является одним из принципов устойчивого развития. Требование рациональности в равной степени относится как к природным (первичным), так и к техногенным (вторичным) минеральным ресурсам. Ресурсный потенциал накопленных на территории Российской Федерации отходов горнодобывающих и связанных с ними производств сравним с ресурсным потенциалом крупных месторождений ТПИ. В то же время деятельность по добыче и переработке минерального сырья, рост накопления сопровождающих эту деятельность техногенных отходов оказывает серьезное негативное воздействие на экосистемы горнопромышленных регионов страны.

Анализ государственной статистики показывает, что за 2005-2017 гг. среднегодовой темп роста накопления отходов добычи полезных ископаемых составил около $6 \%$ при среднегодовом темпе роста их образования и использования 7,5 и 9,1\% соответственно. За указанный период прирост объемов добычи полезных ископаемых составил 18,8 \%. Наблюдается почти шестикратное превышение темпа накопления отходов добычи над темпом роста объемов добычи полезных ископаемых с учетом использованных (утилизированных) отходов в общей массе отходов, образованных при добыче полезных ископаемых. Ежегодный прирост накопленных отходов в последнее десятилетие составляет 2-3 млрд т. Основанный на официальных данных расчет показывает, что к началу 2019 г. на территории Российской Федерации накоплено отходов добычи полезных ископаемых не менее 113 млрд т.

Групповые причины роста накопления отходов добычи и переработки полезных ископаемых - горно-геологические, технологические, экономические, организационно-управленческие, нормативно-правовые. Росту 
объемов переработки отходов препятствует двойное правовое регулирование использования отходов горнодобывающих производств, затрудняющее активное вовлечение в хозяйственный оборот ТМР. Меры экономического стимулирования переработки ГПО недостаточно эффективны, существующий порядок получения прав пользования на разработку техногенных месторождений и действующее налогообложение демотивирует инвесторов, заинтересованный малый и средний горный бизнес.

Российские компании осуществляют добычу и комплексную переработку, как правило, только основных полезных ископаемых. Попутные полезные ископаемые и компоненты, попутная продукция, полученные при добыче и первичной переработке минерального сырья, в значительной части уходят в отходы. Отсутствует государственная поддержка недропользователей, которая стимулировала бы максимально полное извлечение всех полезных компонентов из минерального сырья. Требуют развития регулирующие функции налогов, направленные на вовлечение в переработку вторичного минерального сырья.

Поликомпонентная структура ТПИ и высокие потери при их добыче и обогащении, приводящие к уменьшению налоговой базы по НДПИ, требуют разработки новых подходов к дифференцированному налогообложению. В работе предложена модель расчета дифференцированных налоговых ставок по НДПИ для многокомпонентного природного и техногенного минерального сырья.

Несмотря на огромное количество накопленных и ежегодно образующихся отходов горного производства в Российской Федерации отсутствует единая база данных о ТМО, работа над созданием региональных кадастров ведется разобщенно. Разработан и предложен методический подход к созданию типового регионального кадастра ГПО, а также вариант формирования АБД по ТМС на примере Мурманской области.

Масштаб и характер проблем, связанных с отходами горнодобывающих производств, требуют их рассмотрения в институциональном аспекте, когда отходы горного производства выступают объектом управления в существующей институциональной среде. Возникает необходимость выделения ТМР в отдельную подсистему государственной системы управления недропользованием. Этому способствует переход к новому экологическому регулированию на основе НДТ. 


\section{2. ЭЛЕМЕНТЫ МЕТОДОЛОГИИ ОБЕСПЕЧЕНИЯ РАЦИОНАЛЬНОГО ИСПОЛЬЗОВАНИЯ ВТОРИЧНЫХ МИНЕРАЛЬНЫХ РЕСУРСОВ}

\section{1. Этапы развития научных взглядов на проблему рационального использования и охраны ресурсов недр}

\subsection{1. Появление и сущность двух концепций рационального использования ресурсов недр (1960 г2. - конец 1980-х г2.)}

Проблема образования и использования отходов добычи и переработки минерального сырья не может рассматриваться вне сферы природопользования, поэтому концептуально-методологические аспекты ее решения находятся в области рационального использования ресурсов недр и охраны ОС. Формирование научно-практических знаний в области рационального использования МСР связано с определенными историческими этапами развития горной науки и ее отдельных разделов. Можно выделить следующие этапы развития научных знаний в сфере обеспечения рационального использования ресурсов недр как составляющей природопользования.

1. Аккумулирование отраслевых знаний (1960 гг. - конец 1980 гг.), формирование научно-методической и нормативной базы рационального использования ресурсов недр и охраны ОС в условиях централизованной экономики.

2. Систематизация и обобщение информации в области рационального природопользования, формирование правовой базы недропользования и охраны ОС, осознание потребности в механизме экономического стимулирования обеспечения рационального природопользования и использования ресурсов недр в условиях перехода к рыночным отношениям (1990-е гг. — начало 2000 гг.).

3. Исследование имущественно-правового аспекта ТМО в рыночных условиях; выявление потребности в новых формах экономических отношений хозяйствующих субъектов и в соответствующем правовом и информационном поле, необходимость развития системы государственного регулирования имущественных отношений в сфере природопользования, совершенствования институциональной модели управления недропользованием и защиты ОС (2000 г. — настоящее время).

На первом этапе, с начала 1960-х гг., стали складываться основы горной экономики. К наиболее важным теоретическим разработкам этого времени относится разработка: принципов оптимального планирования горного производства, концепции системного управления отраслью, теории эффективности производственной деятельности, концепции экономической оценки минеральных ресурсов. Этот период связывают с такими учеными, как С.Г.Струмилин, А. А. Минц, К. Г. Гофман, А. А. Арбатов, А. С. Астахов, М. И. Агошков, Ю.В. Яковец, В.С. Немчинов. На объединенной конференции методологических семинаров Академии наук СССР в 1964 г. впервые был использован термин «экономика природопользования», с 1970-х гг. экономика природопользования стала формироваться в отдельную отрасль знаний.

В начале 1980-х гг. для решения проблемы рационального использования и охраны недр были предложены две концепции: 1) конщепиия интенсификаиии, предполагающая интенсивный путь развития горнодобывающей промышленности; 2) 
горно-экологическая конщепщия, рассматривающая проблему рационального использования и охраны недр в единстве с рациональным использованием других природных ресурсов и охраной ОС.

Концепция интенсификации опиралась на экономическую политику перехода народного хозяйства на интенсивный путь развития. Это предполагало решение следующих задач: комплексное освоение крупных сырьевых регионов, оптимизация величины потерь при добыче и переработке минерального сырья, комплексное использование всех содержащихся в сырье полезных компонентов, утилизация вмещающих пород и отходов производства, пересмотр кондиций и вовлечение в эксплуатацию на основе прогрессивных технологий запасов минерального сырья, ранее отнесенных к забалансовым. В сфере потребления минерального сырья предусматривалось снижение расхода сырья за счет применения новых технологий, использования вторичного сырья и отходов, замены минерального сырья искусственными и синтетическими материалами [151].

В развитии концепции интенсификации выделилось два самостоятельных направления. Первое предусматривало создание новых технологий добычи и переработки минерального сырья, позволяющих эффективно извлекать полезные компоненты, вовлекать в переработку бедные и забалансовые запасы, утилизировать вмещающие породы и отходы производства и оптимизировать потери полезных ископаемых на разных стадиях технологического процесса. Это вело к сокращению выбросов и сбросов вредных веществ в природную среду, уменьшению изъятия сельскохозяйственных земель и лесных угодий. Развитие данного направления дало прикладной горно-экономической науке целый спектр показателей эффективности технологий добычи и переработки МСР (показатели сквозного извлечения полезных компонентов в различные виды продукции переработки полезных ископаемых, показатели комплексности использования минерального сырья, показатели уровня малоотходности технологий добычи и переработки и т. д.). С точки зрения теории рационального использования недр существенным достоинством предложенных показателей являлась их сравнимость для предприятий с разными горногеологическими условиями добычи.

Суть второго направления конщепции интенсификации заключалась в интенсивном ресурсосбережении, обусловленном ростом потребности в различных видах сырья с одной стороны и ростом техногенной нагрузки на природную среду, требующим сокращения объёмов ресурсопотребления, с другой. В централизованной экономике недропользования превышение потребности в каком-либо виде минерального сырья над возможностью её удовлетворения приводит к дефициту. Как отмечал академик А. А. Арбатов, «дефицит отдельных видов минерального сырья принимает натуральную форму, когда запасы их весьма ограничены, и экономическую, когда при достаточных природных запасах ограничены ресурсы развития» [119, с. 53]. Поскольку преодоление дефицита в традиционных видах минерального сырья было связано с ростом затрат на него, считалось, что эффективнее заниматься поиском новых видов минерального сырья, таких как: нетрадиционные природные ресурсы (тяжелая нефть, битумы и битуминозные породы, метан подземных вод, газовые гидраты, рассолы, лавы, сапропели); техногенные отходы (шлаки, золы, газы, технические воды); искусственные заменители, полученные переработкой низкокачественного сырья, но сохраняющие его природные свойства при заданном качестве (слюдопласты, слюдениты); синтетические заменители (пластмассы, синтетические смолы и волокна). 
Для систематизации отходов добычи и переработки, учета и анализа потерь минеральных ресурсов в различных отраслях были предложены классификации отходов горнодобывающего и перерабатывающего производств (И. П. Жаворонкова [42], М. Э. Кябби [64]). В 1980-х гг. в научной лексике было закреплено понятие «техногенное месторождение» (К. Н. Трубецкой [130]), которое ввел в 1970-х гг. академик Н. В. Мельников (ИПКОН).

В целом преимущества интенсивного пути развития горной промышленности очевидны: вовлекаются в переработку бедные по содержанию каждого ценного компонента минеральные ресурсы (что особенно важно при ухудшении качества разведанных и осваиваемых месторождений); производятся важные для других отраслей промышленности химические элементы и соединения, не имеющие собственных месторождений; уменьшается загрязнение ОС отходами производства; в ряде случаев улучшаются экономические показатели предприятий.

С другой стороны, концепция интенсификации не учитывала: изменений структуры потребления минеральных и других природных ресурсов; изменений показателей нижней границы содержания полезного компонента, что сказывается на экономической оценке месторождений и их разделении на богатые, средние или бедные; того, что «изменение содержания одного из ... элементов в горной породе неизбежно приводит к обратному изменению содержания других элементов» ${ }^{27}$. Формирование концепции интенсификации определялось отраслевой системой планирования и управления производством, что в конечном итоге приводило к игнорированию территориального (социально-экологического) аспекта природопользования.

Вторая - горно-экологическая - концепция рационального использования ресурсов недр рассматривала ресурсно-технологические аспекты добычи минерального сырья во взаимодействии с природоохранными аспектами. Она получила развитие в работах Т. С. Хачатурова, А. А. Голуба, Е. Б.Струковой, Ю. А. Израэля, П. Г. Олдака и др. В рамках этой концепции изучаются закономерности воздействия человека на ОС в сфере горного производства, взаимосвязь физических и химических процессов, лежащих в основе добычи и переработки полезных ископаемых, с кругооборотом вещества и энергии в биосфере, которая в результате хозяйственной и иной деятельности человеческого общества превращается в биотехносферу [106].

Характерной особенностью горно-экологической концепции является то, что ее методология исследований строится на системном подходе, рассмотрении всех элементов природной среды во взаимосвязи и взаимодействии. Развитие системного анализа привело к современному представлению о природном комплексе как территориально ограниченной, сложной, открытой и самовосстанавливаемой системе взаимосвязанных элементов и компонентов, между которыми происходит массообмен под воздействием естественных и антропогенных факторов [6, 71]. Практическая реализация горно-экологической концепции предусматривала создание научных основ горного мониторинга той части биосферы, которая подвергается воздействию со стороны горного производства, разработку принципов экономической оценки изменения биосферы под его воздействием, а также разработку принципов и путей оптимизации его влияния на ОС.

\footnotetext{
${ }^{27}$ Минеральное сырье и экономия материальных и энергетических ресурсов / А. С. Астахов и др. М.: Недра, 1986. 333 с.
} 
К началу 1990-х гг. сформировались основы нормативного механизма управления природопользованием в целом, началось создание системы информационного обеспечения природопользования, включающей геоэкологическое картирование, мониторинг ОС, государственные кадастры природных ресурсов, методики кадастрового учета отходов [94], отраслевые нормативы и стандарты (ГОСТы, ОСТы, инструкции), регламентирующие состояние природных объектов и природоохранные мероприятия по их восстановлению. Вместе с тем проблема техногенных объектов в указанный период носила производственнотехнологический характер и ее решение полностью зависело от государственных директив.

\subsection{2. Направления развития концепций недропользования в начале становления рыночных отночений (1990 z2. — начало 2000 г2.)}

Второй этап развития концепций рационального использования ресурсов недр (1990-е гг. - начало 2000-х гг.) соответствовал периоду перехода к рыночным отношениям в части проведения земельной реформы и формирования института частной собственности на природные ресурсы. Он характеризуется всплеском законотворческой работы, в том числе в области природопользования (появление первых редакций законов «О недрах» (1992 г.), «Об охране окружающей природной среды» (1991 г.), «Об отходах производства и потребления в Российской Федерации» (1998г.), других нормативных правовых актов).

Особое значение на этом этапе придавалось определению роли и места государства в решении проблем природопользования, разработке мер, стимулирующих комплексное освоение минеральных ресурсов и использование отходов горнодобывающих и перерабатывающих производств, а также участию государства в решении проблемы утилизации отходов. Характерным примером активного участия государства в решении проблемы ГПО стала разработка ФЦП «Отходы» (1996 г.) и федеральной программы «Переработка техногенных образований Свердловской области», получившей статус президентской. Реализация обеих программ была направлена на решение широкого спектра социально-экономических и экологических проблем, связанных с истощением сырьевой базы старопромышленных регионов России.

В качестве основных целей ФЦП «Отходы» декларировалось: создание нормативной и технологической базы для реализации единой государственной политики в сфере обращения с отходами на всех уровнях управления; обеспечение стабилизации, а в перспективе сокращение и ликвидация загрязнения ОС отходами; экономия природных ресурсов за счет максимального вовлечения отходов в хозяйственный оборот. Одной из задач, предусмотренных ФЦП, являлось создание системы управления обращением с отходами, построенной на основе организационно-управленческих, правовых, нормативных, экономических, информационных и контрольных регуляторов.

В научных исследованиях этого периода более четко обозначились горнотехнологическое, горно-экологическое, экономическое (эколого-экономическое, геолого-экономическое) направления природопользования. Горно-технологическое направление, основанное на принципах концепции интенсификации (малоотходность, комплексность использования полезных ископаемых), получило 
свое развитие в работах В. Н. Макарова, К. Н. Трубецкого, В. Н. Уманца, Н. Б. Никитина, Л. А. Барского и др. Развитие горно-экологического направления в рамках горно-экологической концепции начала 1980-х гг. стало откликом на накопившиеся проблемы в МСК, связанные с негативным воздействием ГПО на ОС (К. Н. Трубецкой, А. Б. Макаров, А. Г. Талалай, М. А. Пашкевич и др.).

Экономическое направление, охватывающее эколого-экономические и геолого-экономические аспекты рационального природопользования, развивалось в контексте разработки методов экономической оценки минеральных ресурсов и месторождений, поиска подходов к стимулированию комплексного использования полезных ископаемых, переработки отходов, учитывающих особенности переходного периода. Эколого-экономические вопросы рационального природопользования в тот период в наибольшей степени нашли свое отражение в работах О.Ф.Балацкого, Л.Г. Мельника, А. Ф. Яковлева, А. А. Голуба, Е. Б. Струковой, Е. А. Соловьевой, Н. Я. Лобанова, Ю. А. Черенегова, А. А. Аверченко, А. С. Гумилевского.

Важное место в эколого-экономических исследованиях 1990-х гг. отводилось механизмам рационального природопользования, элементами которых рассматривались: платность, система финансирования природоохранных мероприятий, система стимулирования природоохранной деятельности, создание рынка природных ресурсов, экологическое страхование, ценообразование с учетом экологического фактора на первичные и вторичные ресурсы, реализация государственных и региональных экологических программ. Актуальность внедрения большей части этих элементов сохраняется до сих пор.

К примеру, ФЦП «Переработка техногенных образований Свердловской области» в качестве экономических стимулов предусматривала установление налоговых и иных льгот организациям, перерабатывающим техногенные образования, применение системы льготного кредитования, передачу части средств, подлежащих перечислению во внебюджетные экологические фонды, на договорных условиях в виде субсидий или ссуд организациям, осуществляющим переработку техногенных объектов [97]. Однако, как отмечалось позднее, реально действовал только механизм зачета затрат предприятий переработчиков отходов в качестве платежей.

К концу рассматриваемого периода в недропользовании накопились проблемы, которые являлись следствием негативных тенденций предыдущих десяти - пятнадцати лет: сокращения разведанных запасов полезных ископаемых и ухудшения качества МСБ, связанных с истощением наиболее эффективных месторождений. В 1990-х гг. резко снизился объем геологоразведочных работ (почти в четыре раза), уменьшился поисковый задел, упали темпы освоения новых месторождений (в пять - восемь раз). Новыми открытиями и приростами запасов компенсировалась добыча нефти - на $73 \%$, газа — на $47 \%$, меди - на $33 \%$, цинка - на $57 \%$, свинца — на $41 \%{ }^{28}$.

На этом фоне возрос интерес к техногенным минеральным образованиям как к потенциальным источникам минерального сырья - техногенным

\footnotetext{
${ }^{28}$ Нормативно-правовое обеспечение разработки и воспроизводства минерально-сырьевой базы России: состояние и проблемы. Серия: Экономическая политика // Аналитический Вестник Федерального Собрания. Вып. 29. М., 2000 // Государственная Дума: официал. сайт. URL: http://iam.duma.gov.ru/node/2/4494/15040 (дата обращения: 10.05.2019).
} 
месторождениям. Получили развитие научные исследования техногенных месторождений как сложных геологических объектов, обладающих существенным ресурсным потенциалом (К. Н. Трубецкой, В. Н. Уманец, А. В. Когут, О. Е. Горлова, А. Б. Макаров). Кроме того, возникла потребность в экономической оценке техногенных месторождений как объектов инвестиционной деятельности (В. В. Чайников, В. Т. Борисович, Е. Л. Гольдман и др.). Официальной методической базой для разработки подходов к инвестиционному анализу техногенных месторождений стали «Методические рекомендации по оценке эффективности инвестиционных проектов и их отбору для финансирования» (первая редакция 1994 г.) [80].

Следует выделить разработку рекомендаций по геологическому изучению техногенных объектов АО «Роснедра» и ВНИИгеолнеруд, в результате которой были систематизированы техногенные ресурсы Северного, Северо-Западного и Уральского регионов по отраслям, предприятиям, месту образования, величине запасов и технологиям переработки. Такая систематизация представляла практический интерес в первую очередь для потенциальных инвесторов [144].

Основные результаты рассматриваемого периода: развитие методов экономической оценки природных ресурсов и ТМО (техногенных месторождений), связанное с формированием института оценочной деятельности и развитием методического аппарата оценки; апробация инструмента государственного программного управления к решению проблемы утилизации отходов; формирование системы учета техногенных ресурсов в старопромышленных регионах (что впоследствии послужило информационной базой для реализации областных программ их утилизации); формирование представлений о ТМО как об объектах экономических отношений.

В 1999 г. с целью государственного статистического учета полезных компонентов, содержащихся в МСР, отходах добычи и переработки, потерях полезных ископаемых Постановлением Госкомстата РФ от 18 июня 1999 г. № $44^{29}$ были утверждены формы статистической отчетности. К ним относятся: № 5-гр «Сведения о состоянии и изменении запасов твердых полезных ископаемых», 70-тп «Сведения об извлечении полезных ископаемых при добыче», 71-тп «Сведения о комплексном использовании полезных ископаемых при обогащении и металлургическом переделе, вскрышных пород и отходов производства» и др.

Годом ранее был принят Федеральный закон от 24 июня 1998 г. № 89-Ф3 «Об отходах производства и потребления», включивший отходы добычи и переработки полезных ископаемых в состав отходов производства и потребления, регулируемых данным законом. За год до этого Приказом Госкомитета РФ по охране окружающей среды от 27 ноября 1997 г. № $527^{30}$ был

\footnotetext{
${ }^{29}$ Постановление Госкомстата РФ от 18 июня 1999 г. № 44 «Об утверждении годовых форм федерального государственного статистического наблюдения за запасами полезных ископаемых и их рациональным использованием» // КонсультантПлюс: сайт. URL: http://www.consultant.ru/document/cons_doc_LAW_64163/(дата обращения: 10.11.2019).

30 Приказ Государственного комитета Российской Федерации по охране окружающей среды от 27 ноября 1997 г. № 27 «О федеральном классификационном каталоге отходов» (отменен в 2002 г.).
} 
утвержден федеральный каталог отходов, содержащий в своем перечне, наряду с другими видами отходов, отходы добычи и переработки полезных ископаемых.

В то же время принятый в 1992 г. в первой редакции Закон РФ «О недрах» содержал противоречащее Федеральному закону «Об отходах производства и потребления» положение о праве собственности на отходы горнодобывающих производств. Тем самым данному виду отходов было дано противоречивое толкование правового статуса различными отраслями права, которое переросло в дальнейшем в серьезную проблему, не разрешенную до настоящего времени.

\subsection{3. Последующее развитие концепций рационального использования ресурсов недр и обращения с отходами горного производства (2000 2. - настоящее время)}

Третий период развития научных взглядов и представлений о рациональном использовании ресурсов недр (использовании и охране недр, недропользовании) и обращении с отходами горного производства совпадает с периодом повышения значения экологического фактора и усиления роли государства в экономике.

Термин «недропользование» в работе мы будем понимать в узком смысле: не как совокупность определенных ст. 6 Закона РФ «О недрах» видов пользования недрами, а как один из этих видов, наиболее важный - «разведка и добыча полезных ископаемых, в том числе использование отходов добычи и связанных с ней перерабатывающих производств». Это означает, что понятия «использование ресурсов недр» и «недропользование» рассматриваются как эквивалентные.

Исследование проблем рационального недропользования в контексте добычи и переработки полезных ископаемых сместилось главным образом в область горного права. Свое влияние, по всей видимости, оказала и продолжает оказывать законодательно закрепленная с 1992 г. в Законе РФ «О недрах» расширенная трактовка понятия «рациональное использование и охрана недр», о которой мы упоминали в подразделе 1.1.1. С этих позиций поиск решений различных аспектов проблемы рационального использования ресурсов недр, включая отходы недропользования, осуществляется, как правило, в рамках выработки предложений по повышению эффективности механизма государственного регулирования недропользования.

Сторонники концепции интенсификации М. В. Дудиков и Е. С. Мелехин определяют рациональное использование недр как систему государственных организационных, научно-технических, технологических, экономических, правовых и иных мер, направленных на соблюдение установленного законодательством порядка недропользования, обеспечение полноты геологического изучения недр, эффективное и комплексное использование запасов полезных ископаемых, а также предотвращение загрязнения недр при проведении работ, связанных с пользованием недрами [40]. Авторы считают, что решение накопившихся в области рационального использования недр проблем требует последовательного, комплексного применения мер государственного регулирования, включая институционально-организационное регулирование. Они указывают, что в распределенном фонде недр отмечается существенный прирост количества участков, включающих трудноизвлекаемые, 
некондиционные, низкорентабельные запасы полезных ископаемых, и при действующем правовом режиме недропользования и нулевом уровне рентабельности право пользования недрами на таких участках будет прекращено. Разработка новых технико-технологических подходов себя не оправдывает, из-за этого в стране постоянно ухудшается структура разведанных запасов.

Свое развитие в рассматриваемом периоде получила горноэкологическая концепция, которая позволяет исследовать проблему рационального использования ресурсов недр с позиций рационального природопользования. Придерживающийся этого концептуального подхода С. А. Боголюбов считает, что рациональность использования природных ресурсов, включая ресурсы недр, заключается в том, чтобы постоянно поддерживать такое состояние, когда возможно оптимальное воспроизводство природных ресурсов и не допускаются необратимые последствия для ОС [13].

Однако, как верно замечает А. И. Цуранова [143], следует иметь в виду, что минеральные ресурсы в большинстве своем являются невозобновляемыми природными ресурсами. Применяемый к ним термин «воспроизводство» означает не непрерывно продолжающийся процесс восстановления их полезных свойств и характеристик, а восполнение извлеченных запасов посредством геологического изучения недр, поисков и выявления новых месторождений и участков, обладающих заданными параметрами и полезными свойствами. Такой подход разделяет Е.В. Лунева, которая выделила три критерия рационального использования невозобновляемых природных ресурсов $^{31}$ : максимально полное использование ресурсов и/или извлечение; экономное расходование ресурсов с наименьшими потерями при существующем уровне развития техники и технологий; объем негативного воздействия, при котором ОС способна его самостоятельно переработать.

Рассматриваемый период развития научных взглядов на проблемы рационального недропользования характеризуется ростом внимания к обращению с отходами добычи и переработки минеральных ресурсов. Этому способствовали серьезные изменения в системе государственного управления природопользованием с начала 2000-х гг. (начались структурные реформы, произошли изменения в законодательстве и нормативной базе).

В 2001 г. Постановлением Правительства РФ от 7 декабря 2001 г. № 860 была утверждена новая ФЦП «Экология и природные ресурсы России на период 20022010 годы». Помимо разработки и внедрения новых технологий по переработке и утилизации отходов, включая отходы горных производств, ФЦП предусматривала начиная с 2005 г. ряд мер по развитию государственного регулирования обращения с отходами производства и потребления. Были предусмотрены мероприятия по научнометодическому, технологическому и нормативно-правовому обеспечению недропользования, разработке и внедрению форм государственной статистической отчетности, оценке объектов размещения отходов, созданию и внедрению государственного кадастра и классификатора отходов, экономическому стимулированию их утилизации, разработке научно-методических обоснований для законодательных и нормативно-правовых актов в области обращения с отходами.

31 Лунева Е. В. Рациональное использование природных ресурсов: понятие и правовые критерии // LEXRUSSIA (РУССКИЙ ЗАКОН). URL: https://lexrussica.msal.ru/jour/article/view/406/0 (дата обращения: 15.10.2019). 
Организация учета и отчетности в области обращения с отходами предполагала их количественную и качественную оценку.

В числе прочих мероприятий ФЦП были обозначены: организация контроля за движением отходов и состоянием объектов их размещения, перевод ресурсного потенциала техногенных отходов в запасы минерального сырья, количественная и качественная оценка 40 млрд т техногенных отходов, формирование системы государственного регулирования в сфере обращения с отходами.

Из заявленных в ФЦП задач (2002-2010 гг.) решен вопрос о формировании каталога и кадастра отходов (2014 г.). В то же время отсутствуют согласованные на межотраслевом уровне обоснования нормативно-правовых и законодательных актов, не выполнен перевод ресурсного потенциала 40 млрд т техногенных отходов в запасы минерального сырья.

Указанные проблемы нашли отражение в исследованиях Л. З. Быховского, Е. А. Каменева, Ю. А. Кипермана, М. А. Комарова, Н. Б. Карпенко, В. А Коткина, С. Г. Селезнева. Многими исследователями отмечается необходимость систематизации информации о ТМО - отходах и техногенных месторождениях, их ресурсном потенциале, системной эколого-экономической оценке и государственном учете [10, 123].

Вновь стали актуальными вопросы классификации отходов, вторичных ресурсов, техногенных месторождений в целях экономической оценки инвестиционной привлекательности этих объектов. Одновременно возникли новые проблемы.

Рост потребности к хозяйственному взаимодействию и усиление противоречий между экономическими целями субъектов природопользования в рыночных условиях приводят к конфликту их интересов (рис. 2.1). Причинами этого является низкая мотивация к комплексному использованию полезных ископаемых, монополизация рынка минеральных ресурсов, внутреннее противоречие в государственной системе управления недропользованием (между государством собственником недр и государством - носителем публичных интересов), отождествление государственных управляющих структур с собственником недр (табл. 2.1).

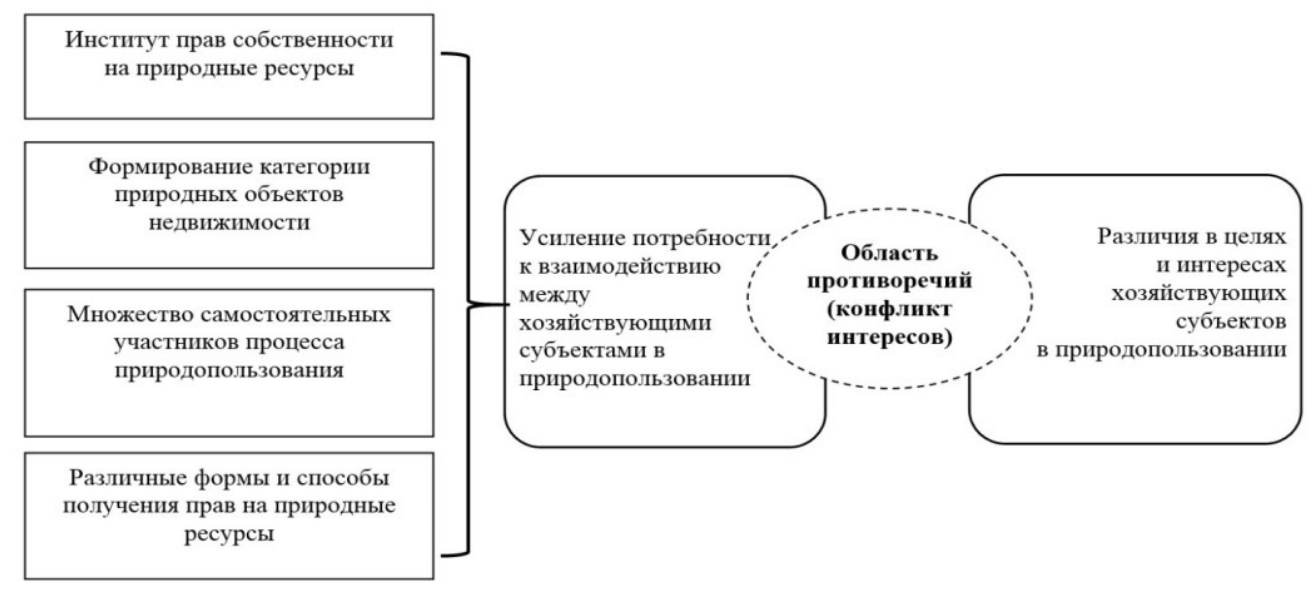

Рис. 2.1. Проявление конфликта интересов хозяйствующих субъектов 
Конфликты интересов субъектов природопользования

\begin{tabular}{|l|l|}
\hline \multicolumn{1}{|c|}{ Конфликтующие интересы } & \multicolumn{1}{|c|}{ Причина } \\
\hline $\begin{array}{l}\text { Интересы государства и } \\
\text { пизнес-интересы }\end{array}$ & $\begin{array}{l}\text { Низкая мотиваиия к комплексному использованиюе } \\
\text { пСР (бизнес-интересы определяются } \\
\text { коньюнктурой рынка: текущей ценой на сырье, } \\
\text { объемом спроса, потребителями) }\end{array}$ \\
\hline $\begin{array}{l}\text { Бизнес-интересы различных } \\
\text { пользователей недр }\end{array}$ & $\begin{array}{l}\text { Высокая монополизация рынка минерального } \\
\text { сырья (сложность выхода на рынок для малого и } \\
\text { среднего горного бизеса) }\end{array}$ \\
\hline $\begin{array}{l}\text { Бизнес-интересы } \\
\text { пользователей недр и } \\
\text { интересы иных } \\
\text { природопользователей }\end{array}$ & $\begin{array}{l}\text { Проявление прав собственности на землю } \\
\text { (права на земельные участки становятся } \\
\text { определяющими в отношениях землевладельцев } \\
\text { и недропользователей, что провоцирует } \\
\text { спекулятивные запросы собственников земли) }\end{array}$ \\
\hline $\begin{array}{l}\text { Интересы государства как } \\
\text { собственника недр и } \\
\text { одновременно носителя } \\
\text { публичных интересов }\end{array}$ & $\begin{array}{l}\text { Сложивииеся противоречия в системе } \\
\text { государственного управления недрами } \\
\text { (ресурсами недр) и обеспечения экологической } \\
\text { безопасности (отождествление } \\
\text { государственных управляющих структур с } \\
\text { собственником недр; ведомственные } \\
\text { противоречия) }\end{array}$ \\
\hline
\end{tabular}

Примером проявления такого рода конфликтов стала ситуация с попыткой отработки участка Ольховского бокситового месторождения, расположенного в пределах Богословского буроугольного месторождения (совместное залегание угля и бокситов является характерной особенностью геологии Северного Урала). Сложные природно-климатические и горно-геологические условия, отраслевой принцип организации горнодобывающей промышленности, а также незаинтересованность предприятий в мелких месторождениях при наличии крупных явились причиной слабой геологической изученности бокситов Северо-Уральского региона, пригодных для открытой разработки.

Единственной заинтересовавшейся на тот период организацией было ОАО «Севуралбокситруда», интерес которого к низкокачественным бокситам был вызван повышением потребности в них в связи с возобновляющимся ростом производства на алюминиевых и глиноземных заводах, повышением конкуренции североуральским бокситам со стороны зарубежных производителей, возможностью обеспечения необходимого качества продукции, снижением содержания карбонатов. Целесообразность разработки бокситов Ольховского участка могла быть обеспечена только в случае списания затрат, связанных с их попутным извлечением, на производство вскрышных работ на Ольховском разрезе. Однако данный проект так и не был реализован из-за несогласованности интересов сторон в отношении цены на сырье.

В области использования природных ресурсов определилась потребность в упорядочении имущественно-правовых отношений между различными участниками процесса природопользования, а в научной лексике укореняются 
такие понятия, как «горное имущество», «минерально-сырьевые активы», что нашло отражение в работах К. Н. Трубецкого [130,], М. Е. Певзнера [98], А. И. Перчика [103], А. А. Арбатова, А. Н. Вылегжанина, В. Ж. Аренса, И. Б. Калинина [49], Г. Ю. Боярко [15].

В современном российском гражданском и горном законодательстве отсутствует определение горного имущества. Наибольшее распространение получило определение, данное в Модельном кодексе о недрах и недропользовании для государств - участников СНГ (ст. 295): «Горным имуществом признается созданное или приобретенное пользователем недр имущество, непосредственно обеспечивающее процесс недропользования, которое не может быть отделено от участка недр без нанесения несоразмерного ущерба недрам (горные выработки, буровые скважины, элементы их крепления и обсадки, система водоотлива и приустьевое наземное оборудование горных выработок, стволы, подъездные пути, маркшейдерские знаки и другое имущество)» ${ }^{32}$. При этом в качестве горного имущества рассматриваются только основные средства в составе общего имущества (основных и оборотных средств) горного предприятия.

Гражданский кодекс РФ (ст. 130) относит к недвижимому имуществу участки недр. Вместе с тем в российском законодательстве статус участка недр - реального объекта имущественных отношений - не определен и не квалифицирован как имущество. Точно также не определен имущественно-правовой статус ТМО, образующихся при добыче и переработке полезных ископаемых. Основная проблема заключается в том, что отношения, связанные с имуществом, которым владеет, распоряжается и пользуется недропользователь, регулируются нормами различных отраслей права: имущественные отношения, в частности оборот (купля, продажа, аренда, залог и др.), - гражданским законодательством, a отношения недропользования (добыча и переработка минерального сырья, использование отходов добычи и переработки) — административным [87].

Свод стандартов оценки (ССО 2010) Российского общества оценщиков (РОО) ССО РОО 2-18-2010 «Оценка стоимости объектов имущества в добывающих отраслях», разработанный в соответствии с Федеральным стандартом оценки (ФСО-2007) и Международным стандартом оценки (МСО2007), также не содержит положений, определяющих специфику такого имущества, как участок недр, отходы, техногенные месторождения.

Научный интерес к вопросам управления отходами добычи и переработки минерального сырья и вторичными (техногенными) минеральными ресурсами сформировался примерно к 2010 г. как отклик на обозначившиеся в этой области проблемы, в числе которых законодательные противоречия и неразвитость институтов, стимулирующих вовлечение отходов недропользования в переработку и способствующих развитию имущественных отношений в сфере недропользования. Проблемы, связанные с идентификацией объектов размещения отходов добычи и переработки как имущества, правовые и институциональные аспекты управления отходами рассматривались в работах В.Е. Коновалова, С. Г. Селезнева,

\footnotetext{
32 Модельный кодекс о недрах и недропользовании для государств - участников СНГ: принят Постановлением Межпарламентской Ассамблеи государств - участников СНГ от 7 декабря 2002 г. № 20-8) // ГАРАНТ: официал. интернет-портал. URL: http://base.garant.ru/2568378/ (дата обращения: 21.09.2019).
} 
Ю. А. Кипермана, В. А. Коткина, Б. К. Михайлова, Н.Б. Карпенко, в том числе и авторами монографии [54, 134, 161].

С вступлением в силу федерального закона № 219-ФЗ от 21 июля 2014 г. ситуация с отходами получила дальнейшее развитие. Переход на новую парадигму государственного экологического регулирования, опирающуюся на принципы НДТ и акцентирующую внимание на эколого-технологической стороне проблемы обращения с отходами добычи и переработки, отодвинул на второй план ее экономический и имущественный аспекты. В то же время ресурсный потенциал накопленных отходов прошлой деятельности и их НВОС при отсутствии институциональных условий, стимулирующих эффективное вовлечение отходов в переработку, в том числе с привлечением малого и среднего бизнеса, по-прежнему представляют собой проблемную область природопользования, требующую дальнейшего исследования.

\section{2. Формирование понятийного аппарата в области управления техногенными минеральными ресурсами}

\subsection{1. Потенциальные минеральные ресурсы как объект управления}

Сложившиеся представления о техногенных объектах (техногенных месторождениях и отходах горнодобывающего производства) базируются в основном на исследованиях и разработках 1970-1980 гг. - этапе формирования концепции интенсификации и ресурсосбережения в МСК.

К настоящему времени можно считать достаточно проработанными вопросы, связанные с обоснованием вовлечения ТМО в хозяйственный оборот; разработаны варианты геологической и технологической классификации, методы экономической оценки техногенных месторождений и техногенных ресурсов. Однако не все аспекты обращения с техногенными объектами (объектами размещения отходов) в достаточной степени исследованы. В частности, в рыночных условиях любой техногенный объект, рассматриваемый как объект управления, должен обладать признаком, определяющим права собственности на него. В этой связи актуализируется вопрос дефиниций, полноты и непротиворечивости понятийного аппарата, представленного юридически значимыми терминами, позволяющими находить в существующем правовом поле решения при возникновении конфликта интересов по поводу техногенных объектов и отходов горных производств, а также в иных случаях.

Научная лексика оперирует значительным объемом понятий, связанных с ГПО как техногенными объектами, большинство из которых имеет авторские трактовки и слабо представлено в российском законодательстве. Юридически не определены понятия «техногенные месторождения», «техногенные образования», «техногенные минеральные объекты». Не установлены однозначно признаки, по которым тот или иной техногенный объект можно квалифицировать как техногенное месторождение или скопление отходов, хотя в ряде законодательных документов эти термины применяются. Например, понятия «техногенные образования» и «техногенные месторождения» включены в Налоговый кодекс РФ (п. 4 ст. 334), в Федеральный закон «О драгоценных металлах и драгоценных камнях», а также в отдельные региональные законы и ряд других документов. 
В горном законодательстве отсутствует определение таких категорий, как «отходы» и «техногенные месторождения». Закон РФ «О недрах» хотя и содержит понятие «отходы добывающего и связанных с ним перерабатывающих производств», но не раскрывает его. Большинство используемых в научной лексике терминов являются узкопрофессиональными (геологическими или техническими) и не имеют законодательного оформления, т. е. не являются юридическими дефинициями. Такая ситуация приводит к нарушению правовых коммуникаций и порождает противоречия между нормами различных отраслей права, прежде всего горного и экологического.

Отсутствие необходимых дефиниций и некорректное применение отдельных понятий приводит к проблеме разграничения прав собственности на отходы, которые могут рассматриваться в качестве ТМР. Актуальность формирования четкого понятийного аппарата определяется: потребностью в систематизации знаний в рассматриваемой области; необходимостью устранения противоречий между хозяйствующими субъектами, исполнительными и контролирующими органами управления в сфере природо- и недропользования; необходимостью формализации хозяйственных отношений в недропользовании при решении проблемы управления TMP, отходами горно-перерабатывающих производств; необходимостью разграничения прав собственности на ТМО; необходимостью формирования организационно-экономического механизма управления ТМО (создания системы учета, оценки, классификации техногенных объектов, привлечения малого и среднего бизнеса в сферу переработки ГПО).

Можно выделить три группы основных терминов и понятий, применяемых в сфере добычи и переработки полезных ископаемых и связанных с ресурсами недр, по степени их правовой определенности и закрепления в нормативных документах (рис. 2.2). Рассмотрим такие базовые понятия, как «полезные ископаемые», «минеральное сырье», «минеральные ресурсы».

\begin{tabular}{|c|c|c|}
\hline \multicolumn{3}{|c|}{ Термины и определения } \\
\hline $\begin{array}{c}\text { Содержание раскрыто } \\
\text { в нормативных правовых } \\
\text { и подзаконных актах, } \\
\text { стандартах }\end{array}$ & $\begin{array}{c}\text { Отражены, но не } \\
\text { определены в нормативных } \\
\text { правовых и подзаконных } \\
\text { актах, стандартах } \\
\text { (устоявшиеся и авторские) }\end{array}$ & $\begin{array}{c}\text { Не применяются } \\
\text { в нормативных правовых } \\
\text { и подзаконных актах, } \\
\text { стандартах (авторские) }\end{array}$ \\
\hline $\begin{array}{l}\text { - месторождение полезных } \\
\text { ископаемых } \\
\text { - отходы производства } \\
\text { и потребления } \\
\text { - вторичные материальные } \\
\text { ресурсы }\end{array}$ & $\begin{array}{l}\text { - полезное ископаемое } \\
\text { - минеральные ресурсы } \\
\text { - техногенные минеральные } \\
\text { ресурсы } \\
\text { - отходы добычи и связанных } \\
\text { с ней перерабатывающих } \\
\text { производств } \\
\text { - техногенные объекты } \\
\text { - техногенные образования } \\
\text { - техногенные месторождения } \\
\text { - минерально-сырьевой } \\
\text { потенщиал }\end{array}$ & $\begin{array}{l}\text { - минерально-ресурсный } \\
\text { потенщиал } \\
\text { - вторичные минеральные } \\
\text { ресурсы } \\
\text { - техногенный минеральный } \\
\text { объект } \\
\text { - потенщиальное техногенное } \\
\text { сырье }\end{array}$ \\
\hline
\end{tabular}

Рис. 2.2. Группировка терминов по признаку их закрепления в нормативных правовых актах 
Горная энциклопедия определяет термин «полезные ископаемые» (англ. minerals) как природные минеральные образования земной коры неорганического и органического происхождения, которые могут быть эффективно использованы в сфере материального производства. Минеральное сырье (англ. mineral raw materials) определяется как товарная продукция горного производства; к нему относятся полезные ископаемые, извлечённые из недр в процессе освоения минеральных ресурсов и подвергнутые необходимой для использования незначительной обработке (обессоливание, обезвоживание, очистка, сушка, фильтрование, дробление) или, в зависимости от вида полезных ископаемых, глубокой переработке из-за невысокой концентрации полезных компонентов и других особенностей для получения технологически ценных товарных продуктов.

Г. В. Секисов и Н. В. Зыков определяют полезное ископаемое как «естественное (или первое производное от него) минеральное вещество, которое на определенном отрезке времени технически реально, экономически эффективно, экологически и социально безопасно можно добыть и использовать для производства минеральной продукции» [112, с. 44]. В данном определении родовым признаком полезного ископаемого является минеральное вещество, а критерием отнесения минерального вещества к полезному ископаемому наличие полезного компонента (составная часть полезного ископаемого) или полезных свойств, определяющих его потребительскую ценность. Любое полезное ископаемое является минеральным веществом, но не всякое минеральное вещество - полезное ископаемое.

Еще одним признаком полезного ископаемого, на наш взгляд, является нерукотворность образующего его минерального вещества (у авторов «естественное минеральное вещество»). То есть полезное ископаемое - это в полной мере «продукт природы», образованный недрами Земли. Поэтому полезное ископаемое («продукт недр») можно определить как природное минеральное вещество, обладающее полезными свойствами или содержащее полезные компоненты, добыча и использование которого технологически возможна, экологически допустима и экономически эффективна в настоящее время или в обозримой перспективе.

Горная энциклопедия определяет минеральные ресурсы (англ. mineral resources) как совокупность полезных ископаемых (минерального вещества, содержащего полезный компонент), выявленных в недрах отдельных регионов, стран, континентов, дна океанов или Земли в целом, доступных и пригодных для промышленного использования и, как правило, количественно оценённых геологическими исследованиями и геологической разведкой. Более широкое определение дает Объединенный комитет по международным стандартам отчетности о запасах CRIRSCO в Руководстве по гармонизации стандартов отчетности: минеральные ресурсы - «концентрация (проявление) минерального вещества, представляющего определенный экономический интерес, в земной коре или на ее поверхности в такой форме и при таком количестве и качестве, которые дают основания предполагать возможность его рентабельного извлечения из недр в обозримой перспективе». Этим же документом термин «ресурсы» (минеральные) включает «минерализацию (в том числе отвалы и хвосты), выявленную и оцененную в результате выполненных исследований и опробования, в пределах которых на основе анализа и использования 
модифицирующих факторов могут быть оценены «запасы» полезного ископаемого» ${ }^{33}$.

Как упомянуто выше, родовым признаком минерального ресурса, так же как и полезного ископаемого, является минеральное вещество, обладающее полезными свойствами или содержащее полезный компонент. Однако относят минеральные ресурсы к полезным ископаемым при наличии возможности их эффективного промышленного освоения в ближайшей (обозримой) перспективе. Не все находящиеся в недрах или извлеченные из недр минеральные ресурсы могут быть успешно освоены.

Основным показателем полезности минеральных ресурсов (ценности запасов) выступает промышленное содержание полезных компонентов с учетом вредных примесей, а главным ограничивающим фактором их промышленного освоения - достигнутый уровень технологического развития, обеспечивающий приемлемую рентабельность. При добыче неизбежно часть оцененных минеральных ресурсов окажется забалансовыми, какая-то их доля перейдет в некондиционные запасы в отходах. Классифицирующим параметром может считаться время разработки и внедрения новых технологий, позволяющих перевести определенную часть неиспользуемых минеральных ресурсов в кондиционные запасы (полезные ископаемые).

Управляющим параметром для кондиционных запасов выступает рентабельность переработки извлеченных из недр полезных ископаемых. Данный показатель отражает экономическую эффективность горного производства и, как правило, ложится в основу принятия решения о переработке минеральных ресурсов более низкого качества. Однако сама рентабельность (в еe разновидностях) зависит не только от научно-технического уровня применяемой технологии, но и от уровня цен на товарный продукт (концентрат). Если на рынке минерального сырья наблюдается устойчивый рост цен, то переработка низкокачественных минеральных ресурсов может оказаться рентабельной, а значит, часть находящихся в отходах «условно полезных» ископаемых перейдет в разряд полезных, пригодных для текущей переработки, поскольку норму прибыли можно обеспечить при более высоких издержках. По нашему мнению, имеется достаточно оснований для того, чтобы не осваиваемые при добыче полезные ископаемые рассматривались не только как объект учета, но и как объект управления на различных уровнях.

Неиспользуемая в процессе разработки месторождения часть минеральных ресурсов может быть отнесена к потенциальным минеральным ресурсам. Применительно к добыче полезных ископаемых потенциальные минеральные ресурсы можно условно рассматривать как разницу между учтенными ГБЗ полезными ископаемыми и освоенными запасами на объекте учета (месторождении, участке недр). Объем потенциальных минеральных ресурсов будет меняться по мере освоения запасов и накопления отходов добычи и переработки.

\footnotetext{
${ }^{33}$ Руководство по гармонизации Стандартов отчетности России и CRIRSCO = Guidelines on Alignment of Russian minerals reporting standards and the CRIRSCO Template (Согласовано гендиректором ФГУ «ГКЗ» 25 августа 2010 г.). С. 41 // GeoKniga: сайт. URL: $\quad$ http://www.geokniga.org/bookfiles/geokniga-rukovodstvo-po-garmonizaciistandartov-otchetov-gkz-i-crirsco-moskva-2010.pdf (дата обращения: 23.02.2019).
} 
Принимая во внимание цели исследования, определим потенциальные минеральные ресурсы как часть минеральных ресурсов, по качеству, количеству, свойствам, месторасположению, горно-геологическим, экологическим и экономическим условиям не отвечающая требованиям промышленного освоения. Требования промышленного освоения задаются всей совокупностью разрешительных документов и регулирующих нормативно-правовых актов. В соответствии с определением применительно к горнодобывающим производствам потенциальные минеральные ресурсы будут включать неиспользуемые извлеченные из недр и остающиеся в недрах забалансовые запасы, некондиционные запасы, остающиеся во вскрышных и вмещающих породах, отвалах или производственных отходах. Факт неиспользования минеральных ресурсов в зависимости от ситуации может относиться к конкретному моменту или к какому-то промежутку времени (например, текущему периоду).

Потенциальные минеральные ресурсы, как и ресурсы, пригодные к текущему промышленному освоению, могут быть классифицированы по видам, месту образования, объемам, видам использования и другим признакам. В научных изданиях понятия «полезное ископаемое» и «минеральный ресурс» считаются синонимичными, т. е. соотносящимися друг с другом по смыслу [69], что справедливо для минеральных ресурсов, сосредоточенных в недрах. Включение в понятие «минеральные ресурсы» минерального вещества, содержащего полезные компоненты и сконцентрированного в отвалах и хвостах, позволяет разделить минеральные ресурсы на природные и техногенные.

\subsection{2. Вторичные минеральные ресурсы: потребность в нормативном закреплении дефиниции}

Минеральные вещества скапливаются в минеральных объектах. Под минеральным объектом будем понимать объект производственнохозяйственной деятельности, содержащий скопления минеральных веществ природного или техногенного генезиса. К минеральным объектам природного генезиса относятся участки недр коренных месторождений полезных ископаемых. К техногенным минеральным объектам принято относить техногенные месторождения и ГПО, размещенные в отвалах, хвостохранилищах, шламохранилищах и т. п.

Одним из существенных вопросов, связанных с обращением ГПО, является их определение как вторичных ресурсов. Это вытекает из концепции индустриального метаболизма, согласно которой приоритетными должны быть задачи не захоронения или уничтожения отходов, а использование их в производстве ${ }^{34}$. В то же время нет однозначной точки зрения на соотношение категорий «горнопромышленные отходы» и «вторичные материальные ресурсы». Данный вопрос имеет немаловажное прикладное значение и заслуживает отдельного рассмотрения.

\footnotetext{
${ }^{34}$ Ayres Robert U., Simonis Udo E. eds. (1994), Industrial Metabolism: Restructuring for Sustainable Development, Tokyo \& New York: United Nations University Press, retrieved 23 November 2010 // United Nations University. URL: http://archive.unu.edu/unupress/unupbooks/80841e/80841E00.htm (accessed: 22.05.2019).
} 
Как указывает Ю. В. Юрченко [150], с юридической точки зрения обращение с вторичными материальными ресурсами, в отличие от обращения с отходами, не требует получения лицензии. В. В. Чайников и Е. Л. Гольдман определяют все неиспользуемые отходы, для которых в данное время отсутствуют условия использования, как вторичные материальные ресурсы. Они отмечают, что «вне сферы конкретной отрасли «отходы» могут квалифицироваться как сырьевые ресурсы для других отраслей, имея при этом достаточно близкую потребительную стоимость» $[144$, с. 36]. Эта точка зрения представляется небесспорной, поскольку подразумевает сохранение и накопление образующихся отходов как потенциальных источников сырья, что при отсутствии механизма учета и классификации, а также знания отраслевых потребностей может привести к негативным экологическим последствиям.

По мнению П. В. Березовского, к вторичным материальным ресурсам может быть отнесена только часть отходов: «Главное различие (отходов и вторичных материальных ресурсов) состоит в наличии потребительских свойств и возможности их использования» [10, с. 38]. По логике автора, отходы становятся вторичными ресурсами по мере выявления их потребительских свойств. Здесь также не учитывается экологическая сторона их накопления. Кроме того, применительно к отходам горного производства потребительские свойства полезных компонентов могут, в силу естественных причин (окисление, выветривание, растворение), ухудшаться значительно быстрее, чем возникнет потребность в них; также могут меняться сами потребности.

В то же время В.П. Березовский разделяет мнение советских ученых М. П. Педана и В. С. Мищенко [99] о том, что главным критерием, отличающим вторичные ресурсы от отходов, является научно-техническая возможность использования последних в данный момент времени: «Под вторичными материальными ресурсами необходимо понимать только ту часть отходов сырья и материалов, которую можно повторно использовать на данном этапе развития науки и техники» [10, с. 39]. Такой же точки зрения придерживаются авторы книги [59].

Сходная позиция у С. С. Трофимца, исследовавшего этот вопрос с правовой точки зрения [127]. Он предложил законодательно разграничить отходы на две категории: которые не могут быть использованы в дальнейшем (по крайней мере в обозримой перспективе ввиду отсутствия технологий) и которые могут использоваться в дальнейшем в хозяйственном процессе и представляют собой вторичные материальные ресурсы. При этом автор отметил, что Федеральный закон «Об отходах производства и потребления» хотя и предусматривает вовлечение отходов в хозяйственный оборот в качестве дополнительных источников сырья, но он не предлагает конкретного механизма такого вовлечения.

Легко заметить, что приведенные выше трактовки ГПО как вторичных материальных ресурсов при всем различии формулировок весьма близки рассмотренному нами понятию потенциальных минеральных ресурсов. Вышеуказанные авторы предлагают либо сразу считать вторичными ресурсами отходы, имеющие потенциал для использования в будущем, либо считать их таковыми при появлении возможности использования. Формулировка В. В. Чайникова и Е. Л. Гольдмана, по сути, совпадает с определением потенциальных минеральных ресурсов, что делает ее уязвимой, поскольку не все потенциальные ресурсы становятся или могут стать вторичными ресурсами в смысле реализации их ресурсного потенциала. 
Вступивший в действие в 2012 г. ГОСТ Р 54098-2010 определяет (со ссылкой на Модельный закон «Об отходах производства и потребления» 2007 $\left\ulcorner.{ }^{35}\right)$ вторичные материальные ресурсы как отходы производства и потребления, в отношении которых существует реальная возможность и целесообразность повторного использования непосредственно или после дополнительной обработки для получения товарной продукции. Кроме того, по ГОСТР 54098-2010, ст. 3.2.1, к вторичным материальным ресурсам в рассматриваемой нами области следует относить, в частности: продукцию первичной (предварительной) переработки отходов, соответствующую требованиям определенных нормативных (ГОСТ, ГОСТ Р, СТО) и/или технических (ТУ, ТО) документов; отходы, специально складированные в техногенных ресурсных накоплениях, для использования их в будущем в качестве вторичного сырья. ГОСТ Р 54098-2010 достаточно четко определил понятие вторичных материальных ресурсов, которое можно использовать как базовую конструкцию для уточнения этого понятия применительно к ГПО. При этом следует принять во внимание рассмотренный выше термин «потенциальные минеральные ресурсы».

На наш взгляд, учет не только возможности, но и целесообразности повторного использования отходов без указания временного интервала использования является важным моментом идентификации ГПО как вторичных материальных ресурсов. При этом повторность использования (рециклинг) как признак вторичности использования материальных ресурсов, в том числе минеральных, следует трактовать в широком смысле. Обладающие потребительскими свойствами отходы, например некондиционные комплексные руды, будут иметь статус вторичных материальных ресурсов, если по мере формирования спроса для них становится возможным и целесообразным не только возвращение в технологический цикл (рециклинг) для доизвлечения основного компонента, но и использование в новой технологической схеме переработки для извлечения попутных полезных ископаемых и компонентов. Другая ситуация - переработка отходов металлургии или сжигание угля в ТЭС. Можно ли считать рециклингом извлечение ценных компонентов из шламов и золошлаковых смесей?

В соответствии со ст. 3.4.2 ГОСТ Р 54098-2010 рециклинг - это процесс возвращения отходов, сбросов и выбросов в процессы техногенеза, включая вовлечение отходов в хозяйственный оборот в качестве вторичных сырья, материалов, но исключая использование в качестве энергоресурсов. Относительно обращения с отходами рециклингом является любой процесс утилизации, при котором отходы перерабатывают в продукцию, материалы или вещества, используемые для первоначальных целей применения или других целей применения. Исключением является получение материалов для использования в качестве топлива или, по европейскому законодательству об отходах [195], для засыпки (например, отработанных карьеров) и балластировки (например, полигонов).

\footnotetext{
35 Модельный закон «Об отходах производства и потребления» (новая редакция): принят Постановлением от 31 октября 2007 г. № 29-15 Межпарламентской Ассамблеи государств - участников СНГ // ГАРАНT: официал. сайт. URL: http://base.garant.ru/2565839/ (дата обращения: 22.05.2019).
} 
Таким образом, широкая трактовка повторного использования означает возвращение отходов в хозяйственный оборот, включая их применение в основном производственном процессе, а также любой другой вид утилизации, в том числе реализацию «на сторону» как сырьевого товара, на что прямо указывает пункт 3.4.19 ГОСТ Р 54098-2010. Как было отмечено выше, статус вторичных материальных ресурсов позволяет это делать без получения лицензии. Отдельным является вопрос собственности на отходы и принятие решения по поводу целесообразности рециклинга.

Следует признать, что само по себе наличие у отходов потребительских свойств, a y предприятий возможностей промышленной переработки производственных отходов не означает, что эти возможности будут реализованы сразу или в ближайшей перспективе, а сами отходы как вторичные ресурсы перестанут накапливаться хотя бы временно. Должна сохраняться возможность использования ресурсного потенциала отходов в той мере, в какой это выгодно их собственнику (и пользователю недр) с учетом всех аспектов, включая затраты на безопасное хранение.

На принятие решения об использовании отходов добычи комплексных руд может оказывать влияние большое количество факторов, определяющих альтернативную стоимость выбора приемлемого варианта. Общим решением может быть повторное использование отходов в текущем производстве для доизвлечения одного или нескольких основных полезных ископаемых, использование в качестве исходного ресурса для добычи попутных полезных ископаемых или отдельных наиболее ценных компонентов и др. Если вовлечение в повторное использование предполагает проектную реализацию, то обобщенным параметром альтернативной стоимости может выступать экономическая эффективность проекта — чистый дисконтированный доход — и другие показатели.

Альтернативой использованию в собственном производстве является реализация отходов «на сторону», например продажа скальных вскрышных пород как строительного материала. Общей альтернативой использованию (утилизации) отходов горного производства является их размещение для хранения и использования в будущем, которое имеет свою альтернативную стоимость в виде издержек хранения и платы за НВОС.

Наряду с термином «вторичные материальные ресурсы» в научном обороте используется близкое к нему по смыслу понятие «вторичные минеральные ресурсы». Этот термин в настоящее время имеет свободное толкование и позволяет отразить отраслевую принадлежность ГПО как вторичных материальных ресурсов. Термин «вторичные минеральные ресурсы» давно используют ученые-химики ИХТТиМ СО РАН, занимающиеся созданием инновационных жаростойких керамических и других материалов из отходов металлургических производств и ТЭС [120]. Его экономическое содержание исследовал П. В. Березовский [10], предложены математические модели оценки эффективности извлечения полезных компонентов из вторичных минеральных ресурсов [90]. По мнению ряда авторов, «вторичными минеральными ресурсами являются, прежде всего, хвосты обогащения и забалансовые руды для дополнительного получения цветных и благородных металлов» [59, с. 539]. А. В. Архипов и С. П. Решетняк считают вторичными минеральными ресурсами весь материал отходов, образующихся после разработки, чаще всего по 
моносырью, поликомпонентных полезных ископаемых [4, с. 5]. Применяя термин «вторичные минеральные ресурсы», авторы обычно рассматривают его либо в узком прикладном аспекте (например, через вещественный состав), либо как синоним вторичных материальных ресурсов применительно к ГПО.

Нормативное определение ВМР отсутствует. Это является недостатком, учитывая юридическую значимость дефиниции. На наш взгляд, закрепление термина «вторичные минеральные ресурсы» в ГОСТ Р 54098-2010 (наряду с терминами «вторичные тепловые ресурсы», «вторичные биоэнергетические ресурсы» и др.) целесообразно с точки зрения активизации вовлечения ГПО в хозяйственный оборот (главным образом, отходов добычи и первичной переработки полезных ископаемых, попадающих под двойное регулирование).

Принимая во внимание требования, предъявляемые к нормативной терминологии, а также конструкцию содержащихся в ГОСТ Р 54098-2010 терминов, семантически однородных рассматриваемому (как разновидность вторичных ресурсов), можно предложить для обсуждения следующую дефиницию: вторичные минеральные ресурсы - содержащие полезные ископаемые и компоненты отходы производства и потребления минерального сырья, для которых существует возможность повторного использования непосредственно или после дополнительной обработки.

Приведенное определение учитывает следующее: 1) родовым является нормативное определение вторичных материальных ресурсов, в котором повторность использования ресурсов является признаком их вторичности; 2) минеральное сырье является товарной продукцией горного производства, получаемой в процессе добычи и подготовки к реализации полезных ископаемых (для ТПИ - обогащения); 3) минеральные ресурсы включают ТПИ, но не ограничиваются ими, определение охватывает все виды минеральных ресурсов, в том числе нефтегазовые и другие; 4) учитываются все ГПО, имеющие ресурсный потенциал (рудные, нерудные, горючие): отходы добычи и обогащения - при производстве минерального сырья; отходы металлургического, химического и топливно-энергетического производств - при потреблении минерального сырья; 5) величина ресурсного потенциала не рассматривается в качестве критерия вторичности, как и сроки повторного использования; эти параметры определяются собственником или пользователем отходов и будут зависеть от совокупности всех существенных для предприятия факторов.

\subsection{3. Техногенные минеральные ресурсы в структуре запасов полезных ископаемых}

В последние годы в научной литературе для обозначения минеральных ресурсов, содержащихся в отходах, все чаще применяется понятие техногенные минеральные pecyрсы. Этот термин, наряду с термином «техногенные месторождения», ввел еще в начале 1970-х гг. академик Н. В. Мельников.

В 1982 г. Академик М. И. Агошков представил концепцию георесурсов, в которой выделил категорию «техногенные георесурсы» - кондиционное и некондиционное твердое сырье, карьерные шахтные и минеральные воды, шахтные газы, горные выработки и ландшафты [1]. В дальнейшем велись исследования в направлении развития этой концепции, в том числе связанные с 
обоснованием техногенных георесурсов, определением их содержания в свете перспектив комплексного освоения недр [111].

В современном контексте техногенные георесурсы и ТМР можно рассматривать как производные общего понятия «техногенные ресурсы», которые трактуют как «часть неиспользуемых в хозяйственной деятельности природных ресурсов - отходы, остатки сырья, материалов, полуфабрикатов, иных изделий или продуктов, образовавшихся в процессе производства или потребления, которые могут быть использованы для создания различных видов потребительных стоимостей» $[148$, с. 275]. Некоторые ученые определяют ТМР как совокупность ТМС, содержащегося в отходах горно-обогатительного и металлургического (химического) производства в пределах какого-либо региона или отрасли в целом [123]. У К. Н. Трубецкого [131], А. М. Гальперина [25] и некоторых других авторов это понятие определяется через запасы техногенного сырья. Например, О. С. Горлова считает, что ТМР - это «совокупность запасов техногенного минерального сырья, содержащегося в отходах горно-обогатительного и металлургического производств, в пределах какого-либо региона или страны в целом» [32, с. 13]. Отсутствие в дефиниции упоминания о золошлаковых отходах ТЭС можно объяснить «георесурсным» подходом к определениям.

По нашему мнению, не все ГПО можно рассматривать как источники минерального сырья даже при наличии полезных компонентов и технологий переработки. Факторами, ограничивающими промышленное использование отходов в качестве ВМР, могут быть недостаточные объемы техногенного сырья, наличие вредных примесей, создающих угрозу для ОС, относительно низкая потребительная стоимость полезных компонентов, когда переработка как способ утилизации становится неэффективной или невозможной. Кроме того, масштабы и негативные экологические последствия накопления отходов могут значительно превышать их пользу как потенциальных ресурсов. Существующая практика свидетельствует, что во многих случаях единственным или целесообразным для недропользователя способом снижения негативного воздействия отходов горнодобывающих и металлургических производств на ОС является их рекультивация.

Мы полагаем, что понятия «техногенные минеральные ресурсы» и «горнопромышленные отходы» имеют различную смысловую нагрузку. Если исходить из концепции рационального использования минеральных ресурсов, то, на наш взгляд, при определении ТМР недостаточно отметить техногенный характер содержащегося в ГПО минерального сырья. Сложившаяся у многих авторов традиция определять одни «техногенные» понятия через другие «техногенные» понятия, не имеющие нормативного закрепления, приводит к ситуации «вещь в себе», в результате получаемые научные рекомендации плохо работают на практике.

Опираясь на действующую нормативную правовую базу (ГОСТ Р 540982010, ст. 3.1 .1 (3), ст. 3.2 .1 (2); ГОСТ Р 52104-2003, ст. 4.8), предложим следующее определение: техногенные минеральные ресурсы - это совокупность минеральных веществ, содержащихся в отходах горнодобывающего и связанных с ним производств, специально складированных в техногенных ресурсных накоплениях для промышленного использования в качестве вторичного минерального сырья. Особенность дефиниции в том, что она не только использует рекомендуемый государственным стандартом термин «техногенные ресурсные накопления» 
(техногенный минеральный объект), но и подчеркивает нормативно закрепленную необходимость специального складирования отходов, которые предполагается использовать в будущем в качестве источника промышленного извлечения полезных компонентов, содержащихся в накопленном минеральном веществе.

Сохранение качественных характеристик некондиционного минерального сырья является весьма важным в контексте целенаправленного формирования техногенных месторождений, решение о которых должно приниматься на ранних стадиях проектирования разработки месторождений, в период оценки и разработки ТЭО кондиций с соответствующим экологическим и экономическим обоснованием. В условиях внедрения НДТ такая стратегия поведения недропользователей является рациональной. Путем сохранения ТМР может создаваться потенциал их запасов (в виде техногенных месторождений) исходя из стратегических интересов развития МСБ и в соответствии с экономическими интересами недропользователей. Поэтому сохранение техногенных ресурсов должно рассматриваться как одна из целей горного производства, требующая определенного финансирования.

Тему рационального сохранения ресурсного потенциала ТМС исследовали А. В. Архипов и С. П. Решетняк на примере многолетнего опыта с учетом северных условий функционирования предприятий горнопромышленного комплекса Мурманской области [4]. ТМР представляют собой «наземную» часть потенциальных минеральных ресурсов. Наиболее проблематичным является сохранение ресурсного потенциала запасов техногенного сырья, извлеченных из недр и не проходивших предварительную обработку. К ним относятся учтенные ГБЗ складируемые с целью перспективного использования, совместно залегающие и попутно извлекаемые низкокондиционные полезные ископаемые, часть вскрышных и вмещающих пород, содержащие полезные компоненты, которые не являются объектом добычи данного производства и не имеют собственных месторождений, но представляют определенную ценность для экономики.

По аналогии с вторичными ресурсами, ТМР можно разделить на две категории: пригодные для промышленной переработки в ближайшей (обозримой) перспективе (представляющие интерес как потенциальный экономический актив) и те, переработка которых возможна лишь в отдаленной перспективе при циклической смене кондиций. Критерием принятия решения о переработке ТМР будет выступать эколого-экономическая целесообразность возможных вариантов, оцениваемых показателями экономической эффективности инвестиционного (технического) проекта по переработке и реализации техногенного сырья и вероятными издержками экологического характера (плата за НВОС и др.). Каждое горное предприятие, выстраивая систему управления отходами производства, самостоятельно оценивает, к какой категории следует отнести те или иные техногенные ресурсы и где для него проходит граница между ближайшим и отдаленным периодами использования ТМР.

При формировании политики управления техногенными ресурсами предприятия необходимо предусмотреть раздельное хранение попутных полезных ископаемых, извлеченных из недр забалансовых запасов, перспективных для освоения некондиционных пород с оптимизацией в этих целях соответствующих финансовых издержек. Следует исходить из того, что техногенные ресурсные накопления, попадающие в категорию пригодных для переработки в ближайшей (обозримой) перспективе, по сути, должны представлять собой техногенные месторождения ВМР. 
ГОСТ Р 54098-2010, ст. 3.2.6, дает общее определение техногенным месторождениям вторичных ресурсов как накопленным залежам вторичных ресурсов, учтенным и содержащимся в установленном порядке в качестве запасов вторичного сырья. Тогда под техногенными месторождениями ВМР следует понимать накопленные в результате хозяйственной деятельности залежи ВMP, паспортизованные, зарегистрированные и содержащиеся в установленном порядке в качестве разведанных и утвержденных запасов вторичного минерального сырья. Такое определение придает качественную и правовую определенность ТМ как выделенной части ТMO, представляющей интерес с точки зрения промышленного освоения ВМР.

Следует различать ТМО, сформированные для хранения ТМС, которые оцениваются по своему ресурсному потенциалу недропользователями или инвесторами как техногенные месторождения (т. е. потенциальные техногенные месторождения), и те ТМО, которые официально получают статус техногенных месторождений в государственной системе недропользования с утверждением и постановкой запасов на государственный баланс.

По действующему законодательству о недрах, перевод техногенных объектов в статус месторождений осуществляется ТЭО кондиций. Если он отсутствует или получены отрицательные результаты (установлена непригодность объекта для освоения), то объект разведки (и оценки) не становится месторождением [124]. С другой стороны, сам по себе факт учета запасов минеральных веществ в техногенном объекте на государственном балансе не является основанием отнесения этого объекта к техногенным месторождениям, а заключенные в нем минеральные вещества могут рассматриваться лишь как потенциальные минеральные ресурсы с точки зрения перспектив их освоения.

В правовом аспекте сохранение ТМР путем формирования техногенных месторождений является обременением недропользователя, поэтому важным вопросом является не только обоснование целесообразности их сохранения для экономики в государственном масштабе, но и выработка соответствующего инструментария, стимулирующего деятельность недропользователей в этом направлении. В противном случае, т. е. при отсутствии мотивации к сохранению извлеченных из недр потенциальных ресурсов, они становятся отходами горной добычи и в конечном счете безвозвратными потерями. Несмотря на общую природу образования, в отличие от ТМР, отходы добычи, равно как и отходы переработки, являются не целью, а одним из побочных результатов горного производства, поскольку ни одна горнодобывающая технология не является абсолютно безотходной технологией.

\section{3. Отходы горнодобывающего производства в уравнениях баланса вещества горной массы}

\subsection{1. Возвратные и безвозвратные отходы добычи и переработки полезных ископаемых}

В Российской Федерации содержание понятия «отходы» наиболее полно раскрыто в нормативных документах гражданской отрасли права: «отходы производства и потребления (далее - отходы) - вещества или предметы, 
которые образованы в процессе производства, выполнения работ, оказания услуг или в процессе потребления, которые удаляются, предназначены для удаления или подлежат удалению» (Федеральный закон РФ «Об отходах производства и потребления» № 89-Ф3, 1998 г.).

В Национальном стандарте Российской Федерации ГОСТ Р 53691-2009 отходы определены как «остатки продуктов или дополнительный продукт, образующиеся в процессе или по завершении определенной деятельности и не используемые в непосредственной связи с этой деятельностью». То же сказано в ГОСТ Р ИСО 14050-2009, ст. 3.12 - «Отходы (waste)»: вещества или предметы, от которых владелец хочет или должен избавиться», что, в частности, соответствует дефиниции «отходы» в Директиве ЕC по отходам (Council Directive 91/156/EEC, 1991).

Горная энциклопедия определяет отходы горного производства как «неиспользуемые продукты добычи и переработки минерального сырья, выделяемые из массы добытого полезного ископаемого (горной массы) в процессах разработки месторождения, обогащения и химико-металлургической переработки» ${ }^{36}$.

Необходимо уточнить, что отходы добычи и переработки - это промышленные отходы, которые являются результатом основного производственного процесса и представляют собой часть минерального вещества извлекаемой и перерабатываемой горной массы, уравнение баланса которой может быть представлено в виде:

$$
V_{\text {гм }}=Q_{\text {пи }}+V_{\text {пмр }}^{\prime}+\mathrm{O}_{\text {д }}+\Delta q_{\text {д }},
$$

где $V_{\text {гм }}$ - объем извлекаемой горной массы при добыче; $V_{\text {пмр }}^{\prime}$ объем потенциальных минеральных ресурсов, извлекаемых в составе горной массы; $\mathrm{O}_{\text {д }}$ - объемы отходов, образуемых в процессе извлечения горной массы; $\Delta q_{\text {д }}$ нормируемые технологические потери при извлечении горной массы; $Q_{\text {пи }}$ масса добытого полезного ископаемого, уравнение баланса которой имеет вид:

$$
Q_{\text {пи }}=Q_{\text {пп }}+\mathrm{O}_{\text {п }}+\Delta q_{\text {п, }}
$$

где $Q_{\text {тп }}$ - объем товарной продукции, получаемой при переработке добытого полезного ископаемого; $\Delta q_{\text {п }}-$ нормируемые технологические потери при переработке полезного ископаемого; О О - объем отходов, образуемых в процессе переработки добытого полезного ископаемого.

Тогда уравнение баланса вещества горной массы примет вид:

$$
V_{\text {гм }}=V_{\text {пмр }}^{\prime}+Q_{\text {пп }}+\mathrm{O}_{\text {д }}+\mathrm{O}_{\text {п }}+\Delta q_{\text {д }}+\Delta q_{\text {п }} .
$$

Часть промышленных отходов добычи и переработки может реализовываться как товарная продукция, направляться в основное производство для доизвлечения полезных компонентов и получения основных видов продукции или использоваться в текущей хозяйственной деятельности предприятия в качестве сырья, материалов (строительство дорог, засыпка выработанного пространства, отсыпка дамб), топлива (метан угольных шахт), что обычно предусматривается технологическим проектом разработки

${ }^{36}$ Горная энциклопедия. URL: http://www.mining-enc.ru/o/otxody-gornogo-proizvodstva (дата обращения: 13.02.2019). 
месторождения и переработки полезного ископаемого, а сами отходы относятся к категории возвратных отходов.

Возвратные отходы разделяются на две группы: используемые в качестве сырья в собственном производстве для получения основных видов продукции и неиспользуемые для получения продукции, реализуемые «на сторону», применяемые во вспомогательном производстве или для хозяйственных нужд. Уравнение баланса возвратных отходов:

$$
\mathrm{O}_{\text {возвр. }}=Q_{\text {сыр. }}^{\text {о }}+Q^{\prime}{ }_{\text {тп }}+Q_{\text {сыр. }}^{\text {в }}+Q_{\text {мат. }}+Q_{\text {топ., }}
$$

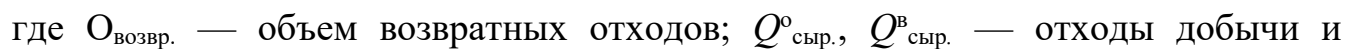
переработки, используемые соответственно в собственном основном и вспомогательном производствах в качестве сырья для получения товарной продукции; $Q^{\prime}$ тп - объем реализуемых отходов добычи и переработки в виде товарной продукции; $Q_{\text {мат., }} Q_{\text {топ. }}$ - соответственно объем отходов добычи и переработки, используемый в качестве материалов и топлива.

Неиспользуемая в основном и вспомогательном производствах нереализуемая часть отходов добычи и переработки (в дефинициях Закона «О недрах» - «отходы добычи и связанных с ней перерабатывающих производств») размещается в природной среде в виде скоплений минеральных веществ (вещества) и представляет собой безвозвратные промышленные отходы, что позволяет записать:

$$
\mathrm{O}_{d}+\mathrm{O}_{\text {п }}=\mathrm{O}_{\text {возвр. }}+\mathrm{O}_{\text {бвз. }},
$$

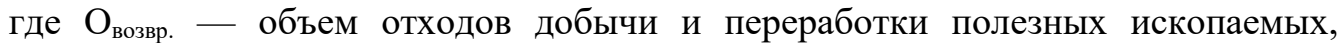
реализуемых или возвращаемых в основное и вспомогательное производства; $\mathrm{O}_{\text {бвз. }}$ - безвозвратные отходы.

Согласно ГОСТ 30772-2001, «безвозвратные отходы (потери) - это отходы производства, которые невозможно, нецелесообразно (неэффективно) или недопустимо использовать повторно». На наш взгляд, говоря об отходах добычи и переработки полезных ископаемых, не вполне корректно отождествлять «безвозвратные отходы» и «безвозвратные потери». Безвозвратные потери - физически навсегда утраченные отходы (угары, газы, растворы и т. п.). Понятие «безвозвратные отходы» имеет более широкую смысловую нагрузку - отходы, которые невозможно (в силу их физической утраты, ограничения доступа), неэффективно (ввиду отсутствия технологии или потребителей, дороговизны переработки) и/или недопустимо (в силу их опасности) использовать в данном производстве. Можно записать:

$$
\mathrm{O}_{\text {бвз. }}=\mathrm{O}_{\text {нак. }}+\mathrm{O}_{\text {бву. }},
$$

где $\mathrm{O}_{\text {нак. }}-$ накапливаемая часть безвозвратных отходов; Обву. - физически утраченная часть безвозвратных отходов.

«Безвозвратность» отходов — относительное понятие, зависящее от времени, применяемой технологии и потребностей рынка. Именно накапливаемая часть безвозвратных отходов является собственно отходами.

Практика показывает, что более 70 \% всех образуемых промышленностью отходов, включая отходы горных производств, не могут быть переработаны в рамках предприятий, которые их производят [146]. Для горно-обогатительных производств это означает, что применяемые 
недропользователем технологии добычи и переработки не позволяют снизить образование отходов и при этом сохранить достигнутый уровень рентабельности производства. Снижение уровня образования отходов и повышение коэффициента переработки уже образованных отходов возможно при реализации технологических инноваций, а с учетом экологического фактора — при внедрении НДТ.

Можно заключить, что отходы добычи и связанных с ней перерабатывающих производств - это нереализуемые и неиспользуемые (в том числе для закладки горных выработок) накапливаемые отходы горного производства. Иными словами, это выведенные из хозяйственного оборота побочные продукты добычи и переработки извлекаемой из недр горной массы, представленные скоплениями минерального вещества в техногенных объектах (объектах размещения отходов - отвалах, терриконах и др.). Жизненный цикл этих объектов (а значит, и образующих их отходов), как правило, превышает срок отработки лицензионных участков месторождений.

\subsection{2. Разновидности накапливаемых отходов как объектов управления}

Перспективу использования накопленных отходов сложно оценить на стадии проектирования, несмотря на то что проектами разработки месторождений должны предусматриваться мероприятия по обращению с отходами: размещение, утилизация, обезвреживание, хранение (захоронение) или рекультивация. В то же время с учетом длительного жизненного цикла горных предприятий, развития технологий и тенденций отраслевых рынков возможность переработки отходов может быть определена в рамках самостоятельных проектов или программ. Кроме того, часть объектов размещения отходов может быть включена в технологическую схему производства. Поэтому накапливаемые отходы с учетом временного фактора предлагается разделить на две группы: временно складируемые (отходы горнодобывающего производства, жизненный цикл которых определяется сроком использования применяемой технологии утилизации либо сроком реализации отходов как товарных продуктов) и постоянно накапливаемые (жизненный цикл больше жизненного цикла горного предприятия):

$$
\mathrm{O}_{\text {бвз. }}=\mathrm{O}_{\text {вс }}+\mathrm{O}_{\text {пн, }}
$$

где $\mathrm{O}_{\text {вс }}, \mathrm{O}_{\text {пн }}$ - соответственно объемы временно складируемых и постоянно накапливаемых отходов горнодобывающего и перерабатывающего производств.

Временно складируемые отходы представляют собой вторичные ресурсы (минеральное сырье, строительные материалы, топливо), образуемые в процессе функционирования технологического комплекса на лицензированных участках разрабатываемого месторождения. Они могут быть использованы в том числе и по истечении срока его функционирования на некоторых участках. Не нашедшие применения временно заскладированные отходы переходят в категорию накопленных отходов.

Постоянно накапливаемые отходы при необходимости должны быть обезврежены, захоронены или рекультивированы (что, как правило, предусматривается проектом освоения месторождения). Окончательный вид уравнения баланса минерального вещества горной массы: 


$$
V_{\text {гм }}=V_{\text {пмр }}^{\prime}+Q_{\text {пा }}+Q^{\prime}{ }_{\text {тп }}+Q{ }^{\prime \prime}{ }_{\text {тп }}+\mathrm{O}_{\text {мат }}+\mathrm{O}_{\text {топ. }}+\mathrm{O}_{\text {вс }}+\mathrm{O}_{\text {пн }}+\Delta q_{\text {д }}+\Delta q_{\text {п }}
$$

где $Q{ }^{\prime}$ тп - товарная продукция, произведенная из отходов добычи и переработки.

Структура баланса горной массы справедлива для любого уровня иерархии системы управления недропользованием, однако на государственном уровне целесообразность сохранения потенциальных минеральных ресурсов, а значит, и соотношения между их объемами и объемами отходов, определяется, в первую очередь, потребностями национальной экономики и состоянием МСБ, а также глобальным спросом на различные виды минерального сырья.

Для региона в данной структуре важным элементом является соотношение между потенциальными минеральными ресурсами и отходами. Это связано с тем, что перспектива переработки ресурсов может привлекать инвестиции и создавать новые рабочие места, в то же время накопление отходов исключает альтернативное использование земли территорий и создает экологическую угрозу ОС и населению. Для недропользователя основными факторами, влияющими на структуру извлекаемой горной массы, являются: состав и качество добываемых полезных ископаемых, горно-геологические условия ведения работ, конъюнктура рынка, наличие эффективных технологий переработки полезных ископаемых и утилизации отходов, экологические ограничения и стимулы.

В формате структуры извлекаемой горной массы должен определяться объект управления. В этом аспекте в соответствии с действующим гражданским законодательством отходы могут рассматриваться как часть имущества хозяйствующего субъекта, в качестве которого выступают недропользователь, государство, иные юридические и физические лица, реализующие свои права собственности: право владения, пользования (использования), распоряжения.

Используемые в текущей деятельности возвратные отходы по своей экономической сути представляют оборотные активы: 1) в производстве ВМР как часть отходов добычи и переработки, которая может быть вовлечена: в основное производство в качестве ТМС для извлечения полезных компонентов; во вспомогательное производство в качестве материалов, топлива; 2) 6 обращении - часть отходов, реализуемая в качестве товарной продукции или передаваемая иным хозяйствующим субъектам на определенных условиях.

Безвозвратные отходы - временно складируемые (отходы на хранении) и постоянно накапливаемые, захораниваемые. Согласно Федеральному закону «Об отходах производства и потребления», хранение отходов - это их складирование сроком более чем одиннадцать месяцев в целях утилизации, обезвреживания, захоронения; захоронение - изоляция отходов, не подлежащих дальнейшей утилизации, в спецхранилищах.

Важной предпосылкой рационального использования отходов как ВМР является технология их складирования, позволяющая сохранить потребительские свойства заключенных в них полезных компонентов и обеспечить безопасность ОС. Рекультивированные или захороненные отходы должны быть переданы в государственную учетную систему - реестр отходов. До их списания ответственность за их содержание и состояние несет хозяйствующий субъект - недропользователь. 


\section{4. Отходы недропользования и техногенные минеральные объекты}

\subsection{1. Отходы недропользования горнодобывающей промышленности}

Согласно ГОСТ Р 55100-2012, горнодобывающая промышленность охватывает комплекс отраслей по добыче и первичной обработке (обогащению) полезных ископаемых, включая топливную, горно-химическую, горнорудную отрасли, а также добычу строительных материалов, драгоценных металлов и камней. Они образуют сектор добычи ТПИ, который является частью первичного сектора экономики Российской Федерации.

Согласно ОКВЭД 2, предприятия вышеуказанных отраслей осуществляют экономическую деятельность «Добыча полезных ископаемых», которая не распространяется на металлургическое и химическое производства, а также ТЭК. Таким образом, добыча и обогащение руды и иных минералов, производство концентратов как первого товарного продукта в цепочке создания добавленной стоимости относится к горнодобывающей промышленности, а использование этого продукта в качестве металлургического или химического сырья или топлива по ГОСТ Р 55100-2012 не относится к горнодобывающей промышленности. Соответственно, шлаки, шламы, золы, являющиеся отходами обработки металлических и неметаллических руд, производства тепловой или электрической энергии на твердом топливе не относятся к отходам горнодобывающей промышленности. Следовательно, понятие «горнопромышленные отходы», включающее кроме отходов добычи и переработки отходы основных производств горнометаллургических и горно-химических компаний, а также отходы сжигания углей в ТЭС, шире понятия «отходы горнодобывающей промышленности».

ГОСТ Р 55100-2012 определяет отходы горнодобывающей промышленности как «пустые породы, извлекаемые при добыче вместе с полезным ископаемым, а также хвосты, образуемые при переработке полезных ископаемых» (пустая порода: горная масса, не содержащая полезного ископаемого или содержащая его в непромышленных концентрациях)». Выделение отходов горнодобывающей промышленности в отдельную категорию продиктовано логикой гармонизации российской и европейской систем стандартизации в области ресурсосбережения и обращения с отходами на основе НДТ. В контексте этой логики был разработан национальный стандарт ГОСТ Р 57677-2017, который ввел и определил понятие «отходы недропользования» как «отходы, образующиеся при добыче полезных ископаемых и связанных с ней перерабатывающих производств».

Несмотря на то что ГОСТ Р 57677-2017 к отходам недропользования относит отходы добычи всех полезных ископаемых, включая нефть и природный газ, он распространяется лишь на отходы, образующиеся при добыче ТПИ и связанных с ней перерабатывающих производств, в полном соответствии с разделом «В» ОКВЭД 2. Связанные с добычей полезных ископаемых перерабатывающие производства классификатор ОКВЭД 2 трактует как дополнительные виды работ по подготовке минерального сырья к реализации, к которым относятся дробление, измельчение, очистка, просушка, сортировка, обогащение руды и угля, сжижение природного газа и агломерация твердого топлива. Последующие технологические переделы, связанные с 
использованием сырья для производства продукции или энергии, относятся к видам экономической деятельности «Обработка» (раздел «С» ОКВЭД 2) или «Обеспечение энергией» (раздел «D» ОКВЭД 2).

До появления ОКВЭД 2 понятие «переработка» как совокупность технологических процессов традиционно охватывала не только извлечение ТПИ из недр и их первичную переработку, но и последующую переработку обогащенных металлических и неметаллических руд. Это позволяло широко трактовать отходы добычи и связанных с ней перерабатывающих производств - как горнопромышленные отходы, источником которых являются предприятия всего горнопромышленного комплекса, а также работающие на твердом ископаемом топливе предприятия ТЭК. ГПО в литературе, как правило, отождествляются с техногенными отходами.

Такая терминологическая традиция косвенно поддерживалась с 1991 г. старой российской системой национальных счетов на основе международного стандарта СНС 1968 г. («Синяя книга»). В 2014 г. Россия перешла на новый международный стандарт СНС-2008 («Зеленая книга»). Одним из результатов этого стал переход на новые общероссийские классификаторы видов экономической деятельности (ОКВЭД 2) и продукции (ОКПД 2), что повлекло за собой необходимость уточнения терминологии, в том числе связанной с отходами добычи и переработки полезных ископаемых.

В августе 2018 г. руководитель Роснедр Е. Киселев анонсировал проект федерального закона о внесении изменений в Закон РФ «О недрах», который должен заменить термин «отходы добычи и связанных с ней перерабатывающих производств» термином «отходы недропользования». Согласно законопроекту к отходам недропользования предлагается отнести вскрышные и вмещающие породы, шламы, хвосты обогащения полезных ископаемых и иные отходы геологического изучения, разведки, добычи и первичной переработки минерального сырья, в том числе представленные техногенными месторождениями ${ }^{37}$.

Предлагаемое в законопроекте определение отходов недропользования соответствует ГОСТ Р 55100-2012 и исключает отходы добычи нефтегазовых ископаемых. Разработчики российского стандарта, в целом ориентирующиеся на европейское законодательство об отходах, в том числе об отходах горнодобывающих производств [192], ограничили распространение понятия «отходы недропользования» сектором добычи ТПИ. Причиной, возможно, стало то, что Закон РФ «О недрах» (ст. 6) рассматривает получение и использование отходов как составную часть процесса добычи, отделяя разведку и добычу ТПИ от разведки и добычи углеводородного сырья. Это прослеживается также на организационно-управленческом уровне в структуре Федерального агентства по недропользованию и в части нормативного обеспечения добычи ТПИ и добычи углеводородного сырья. Исходя из действующих нормативных документов отходы горнодобывающей промышленности - это отходы недропользования,

37 Минприроды России намерено активизировать вовлечение отходов горнодобывающей промышленности во вторичное использование // Министерство природных ресурсов и экологии Российской Федерации: официал. сайт. URL: http://www.mnr.gov.ru/press/news/minprirody_rossii_namereno_aktivizirovat_vovlechenie_otkhod ov_gornodobyvayushchey_promyshlennosti_vo/ (дата обращения: 10.04.2019). 
образующиеся при добыче ТПИ. Если вышеуказанный законопроект будет принят без изменений, то для научного оборота эти два термина станут равнозначными на законном основании.

\subsection{2. Классы опасности горнопромышленных отходов и Федеральный классификационный каталог отходов}

Одним из наиболее важных классификационных признаков ГПО, имеющим важное практическое значение для недропользователей из-за накладываемых ограничений на обращение с опасными отходами, необходимости их обезвреживания и т. д., является класс опасности, который устанавливается по степени возможного НВОС при непосредственном или опосредованном суммарном воздействии на нее опасных веществ в составе отхода.

Класс опасности вида отходов определяется его химическим и/или компонентным составом и устанавливается на основании сведений, содержащихся в Федеральном классификационном каталоге отходов и банке данных об отходах, формируемых Росприроднадзором согласно документу «Порядок ведения государственного кадастра отходов» ${ }^{38}$. При отсутствии вида отходов в ФККО и БДО класс опасности устанавливается на основании критериев, утвержденных приказом Минприроды России № 536 от 4 декабря 2014 г, который вступил в силу 16 января 2016 г. В настоящее время применяются два таких критерия: 1) степень опасности отхода для ОС (определяется расчетным путем); 2) кратность разведения водной вытяжки из отхода, при которой вредное воздействие на гидробионты отсутствует (определяется экспериментальным путем).

Если на основании применения первого критерия получен $\mathrm{V}$ класс опасности, для его подтверждения проводится проверка с применением второго критерия. При несовпадении значений класса опасности, установленного по первому и второму критериям, устанавливается класс опасности отхода, определенный на основании второго критерия. Расчетные методики определения количественных значений критериальных показателей (1) и (2) приведены в приказе Минприроды России № 536 от 4 декабря 2014 г.

Порядок отнесения отходов I-IV классов опасности к конкретному классу, которым на практике должны руководствоваться хозяйствующие субъекты, в процессе деятельности которых образуются отходы (за исключением радиоактивных, биологических и медицинских отходов), определен приказом Минприроды России № 541 от 5 декабря 2014 г. ${ }^{39}$. Основу существующей методики содержания и применения критериев отнесения отходов к классам опасности заложил приказ Минприроды России от 15 июня 2001 г., действующий до 2016 г. Он включал не только количественные, но и качественные критерии, которые в настоящее время

\footnotetext{
${ }^{38}$ Порядок ведения государственного кадастра отходов: утв. Приказом Минприроды России № 792 от 30 сентября 2011 г.) // ГАРАНТ.PУ: сайт. URL: https:/www.garant.ru/products/ipo/prime/doc/12092135/ (дата обращения: 10.03.2019).

39 Порядок отнесения отходов I-IV классов опасности к конкретному классу опасности (с изменениями 2016 г.): утв. Приказом Минприроды России № 541 от 5 декабря 2014 г. // Консорциум Кодекс: сайт. URL: http://docs.cntd.ru/document/420327017 (дата обращения: 12.04.2019).
} 
хотя и потеряли свой официальный статус, но широко используются как удобный методический материал (табл. 2.2).

Таблица 2.2

Качественные критерии отнесения отходов к классу опасности для окружающей природной среды (OC)

\begin{tabular}{|c|l|l|}
\hline $\begin{array}{c}\text { Степень } \\
\text { вредного } \\
\text { воздействия на } \\
\text { ОС }\end{array}$ & \multicolumn{1}{|c|}{$\begin{array}{c}\text { Качественные критерии отнесения отходов } \\
\text { к классу опасности }\end{array}$} & \multicolumn{1}{|c|}{$\begin{array}{c}\text { Класс } \\
\text { опасности }\end{array}$} \\
\hline $\begin{array}{c}\text { Очень } \\
\text { высокая }\end{array}$ & $\begin{array}{l}\text { Воздействие на ОС приводит к } \\
\text { кардинальному изменению экологической } \\
\text { системы, восстановительный период } \\
\text { отсутствует }\end{array}$ & $\begin{array}{l}\text { I класс - } \\
\text { чрезвычайно } \\
\text { опасные }\end{array}$ \\
\hline Высокая & $\begin{array}{l}\text { Воздействие на ОС приводит к серьезному } \\
\text { нарушению экологического баланса с } \\
\text { периодом восстановления не менее тридцати } \\
\text { лет после полного устранения источника } \\
\text { вредного воздействия }\end{array}$ & $\begin{array}{l}\text { II класс - } \\
\text { высокоопасные }\end{array}$ \\
\hline Средняя & $\begin{array}{l}\text { Воздействие на ОС приводит к нарушению } \\
\text { экологической системы с периодом } \\
\text { восстановления не менее десяти лет, после } \\
\text { чего влияние источника заражения } \\
\text { снижается к минимуму }\end{array}$ & $\begin{array}{l}\text { III класс- }- \\
\text { умеренно } \\
\text { опасные }\end{array}$ \\
\hline Низкая & $\begin{array}{l}\text { Воздействие на ОС приводит к } \\
\text { определенным нарушениям экологической } \\
\text { системы, но при этом она способна } \\
\text { самовосстанавливаться в течение трех лет в } \\
\text { среднем }\end{array}$ & $\begin{array}{l}\text { IV класс - } \\
\text { малоопасные }\end{array}$ \\
\hline Очень низкая & $\begin{array}{l}\text { Воздействие на ОС не приводит к каким- } \\
\text { либо нарушениям экологической системы, ее } \\
\text { восстановление не требуется. Отходы такого } \\
\text { типа рассматриваются как инертные }\end{array}$ & $\begin{array}{l}\text { V класс - } \\
\text { практически } \\
\text { неопасные }\end{array}$ \\
\hline
\end{tabular}

Примечание. Составлено по данным сайтов:

http://www.ecobasis.ru/2016/06/22/othody и http://base.garant.ru/2158155/\#friends.

Главным классификатором отходов является Федеральный классификационный каталог отходов, который является составной частью Государственного кадастра отходов. В свою очередь, ГКО является частью системы государственного управления в области обращения с отходами производства и потребления в Российской Федерации. ГКО представляет собой интегрированный информационный ресурс, в котором систематизированы сведения об отходах, их свойствах, потенциальной опасности и ресурсной ценности, а также сведения о существующих объектах размещения отходов и технологиях использования и обезвреживания. 
Государственный кадастр отходов кроме ФККО включает государственный реестр объектов размещения отходов и БДО, содержащий сведения об отходах и технологиях утилизации и обезвреживания. Любое лицо, образующее отходы либо связанное с обращением с отходами, включая ГПО, может узнать класс их опасности из ФККО. В настоящее время действует ФККО 2019, утвержденный Приказом Роспотребнадзора № 242 от 22 мая 2017 г. с изменениями, вступившими в силу 8 декабря 2018 г.

Российский классификатор отходов систематизирован на основе идентификационных кодов, присвоенных отдельным видам отходов. Изначально (в 1997 г.) коды были шестизначными, в современной редакции одиннадцатизначные (с 1 августа 2014 г.). Кодовая структура ФККО 2019 отражает следующие характеристики отходов: источник происхождения вида отходов и их состав (первые восемь знаков кода); агрегатное состояние и физическая форма (девятый и десятый знаки кода); класс опасности вида отхода для ОC (цифры 1-5 соответствуют I-V классам опасности). Цифра 0 в одиннадцатом знаке кода используется для блоков, групп и подгрупп.

В ФККО 2019 двузначный кодификатор агрегатного состояния и физической формы отражает специфические субстанции и их состояния, представляющие собой отходы (например, 10 - жидкое/ растворы; $20-$ твердое / смесь форм; 22 - стружка; 41 - порошок и т. д.). Первая цифра кода означает блок, например, блок 2 - Отходы добычи полезных ископаемых; цифры 2-3-4-5-6 обозначают происхождение или источник, технологический процесс, в результате которого получен отход, например, 222120 - отходы добычи металлических руд; цифры 7-8 обозначают химический состав, например, 22212001.

В ФККО 2019 блок 2 включает пять подразделов: отходы проведения вскрышных работ при добыче полезных ископаемых; отходы добычи топливноэнергетических полезных ископаемых; отходы добычи металлических руд; отходы добычи прочих полезных ископаемых; отходы прочих видов деятельности в области добычи полезных ископаемых, включая геологоразведочные, геофизические и геохимические работы. Если пройтись вглубь подраздела 22, получим, например: 22000000000 Отходы добычи металлических руд; 22200000000 Отходы добычи и обогащения руд цветных металлов; 22210000000 Отходы добычи и обогащения медных руд; 222120 00000 Отходы обогащения медных руд; 22212001395 Отходы (хвосты) обогащения медных руд, практически неопасные (5), класс опасности - V; (39) агрегатное состояние, физическая форма - Прочие дисперсные системы.

ФККО 2019 как практический инструмент предназначен, главным образом, для предприятий, занятых в сфере утилизации отходов. Имеется в виду, что каждый вид отходов требует разных условий для транспортировки, хранения и утилизации. Например, при перевозке бытовых отходов необходимо составлять паспорт груза, в котором отражаются сведения из ФККО. С точки зрения обращения с отходами горного производства, на наш взгляд, ФККО хотя и полезный, но малоинформативный инструмент. Следует учесть, что ФККО довольно часто обновляется, поэтому в Интернете есть несколько сайтов, представляющих интерактивные online-версии ФККО.

В соответствии с Федеральным законом № 89-Ф3 [169] (ст. 14) недропользователи, у которых в процессе деятельности образуются отходы I-V 
классов опасности, обязаны осуществлять их отнесение к конкретному классу опасности и подтверждать это отнесение в органе Росприроднадзора. Подтверждение не требуется для отходов, включенных в ФККО. На основании данных о составе отходов, оценки степени их НВОС составляется паспорт отходов I-IV классов опасности. Критерии отнесения отходов к I-V классам опасности по степени НВОС утверждены Приказом Минприроды России от 4 декабря 2014 г. № 536 [181].

Отходы горнодобывающего и связанных с ним перерабатывающих производств как ТМО характеризуются обычно комплексным составом сырья. Его использование предваряется геологическим изучением и подсчетом запасов с постановкой на государственный баланс по разделу «Техногенное сырье». Учету подлежат, в частности, запасы полезных ископаемых во вскрышных породах, спецотвалах и других техногенных образованиях.

Постановке на государственный и территориальный балансы, кроме того, подлежат: балансовые и забалансовые запасы полезных ископаемых, добытые из недр и складированные в спецотвалы; запасы полезных компонентов в отвальных хвостах обогатительных производств и других техногенных образованиях, если они вовлечены в разработку или получили по результатам геологического изучения (доизучения) положительную эколого-экономическую оценку.

\subsection{3. Обобщенная классификация горнопромыщленных отходов}

В литературе можно найти различные классификации и классифицирующие признаки горнопромышленных (техногенных) отходов. Эти классификации и образующие их признаки применяются в зависимости от задач исследования. К наиболее известным можно отнести классификации, разработанные М. Э. Кябби, И. П. Жаворонковой, К. Н. Трубецким, Л.А.Барским, В. А. Макаровым， Б. К. Михайловым. На основе их анализа можно выделить несколько наиболее существенных классифицирующих признаков ГПО: морфологический, состав и источник образования отходов, тип объекта хранения, длительность хранения, негативное воздействие, направления возможного использования.

I. По морфологическому признаку ГПО делят на два типа:

1. Насыпные ГПО (представляют собой холмы и терриконы), к которым относятся:

a) терриконы угольных шахт и отвалы разрезов;

б) отвалы рудников и карьеров руд цветных, чёрных и редких металлов, сложенные дезинтегрированными вскрышными и вмещающими породами, а также убогими забалансовыми рудами;

в) техногенные россыпи, образующиеся при разработке россыпных месторождений и из отходов золоторудных обогатительных фабрик;

г) шлакоотвалы цветной и чёрной металлургии.

2. Наливные ГПО (образуются при заполнении впадин земной поверхности), к которым относятся:

a) отходы обогащения руд (шламо- и хвостохранилища горнообогатительных фабрик);

б) шламоотвалы цветной и чёрной металлургии; 
в) золо- и шлакоотвалы энергетического комплекса, возникающие при гидравлическом удалении золы и шлаков с теплоэлектростанций;

г) шламоотвалы химических производств.

II. Во многих источниках ГПО классифицируют по составу [124, 131, 148], но объединяют их при этом в группы исходя из технологических особенностей и отраслевой принадлежности образующих их предприятий; поэтому корректнее, на наш взгляд, данный признак обозначить как «состав и источник образования отходов»:

1. Породные ГПО, состоящие из природных горных пород и представленные глыбово-щебенистым материалом, а также шламо- и хвостохранилищами обогатительных фабрик.

2. ГПО пирометаллургических процессов цветной и чёрной металлургии, сложенные шламами и шлаками.

3. ГПО теплоэлектростанций, сложенные золой и шлаками.

4. ГПО химического производства (шламы).

III. По типу объекта хранения ГПО можно классифицировать как отходы:

1. Добычи - отвалы горнодобывающих предприятий, сложенные преимущественно крупнообломочным материалом вскрышных и вмещающих пород, некондиционных руд, а также балансовых руд из числа их потерь при добыче из некондиционных прослоев.

2. Обогащения - шламохранилища и хвостохранилища, сложенные преимущественно мелкозернистым материалом.

3. Переработки - отвалы металлургических и гидролизных производств в виде шлаков и шламов и т. д.

IV. По длительности хранения в «техногенной» традиции (отходы как TMO) обычно выделяют два типа ГПО: текущие (актуальные), формирующиеся при текущей добыче и переработке полезных ископаемых, и лежалые (отходы прошлых лет), числящие на балансе предприятия как временно заскладированные либо неучтенные - бесхозные («бесхозяйные» по Гражданскому кодексу РФ), не числящиеся на балансе. Представляется, что с учетом обновляемых в сфере обращения с отходами нормативов и понятий в рамках перехода к регулированию на основе НДТ по признаку длительности хранения следует выделить три типа отходов:

1. Временно складируемые (накапливаемые) на срок до одиннадцати месяцев.

2. Находящиеся на хранении более одиннадцати месяцев в ожидании использования (утилизации), обезвреживания.

3. Находящиеся на хранении в ожидании захоронения.

V. По НВОС в «техногенной» традиции до введения нового экологического регулирования ГПО чаще всего подразделяли на два типа: неопасные, представленные слабо разрушающимися во время хранения породами, и опасные - загрязняющие атмосферу и гидросферу окисляющиеся породы, шлаки и шламы, а также пылящие отходы. Однако, как было сказано выше, в соответствии с Федеральным законом № 89-Ф3 (в редакции 2016 г.) лица, образующие отходы, должны отнести их к конкретному классу опасности, а на отходы I-V класса опасности обязаны составить паспорт. В этой связи классификацию ГПО по признаку НВОС целесообразно уточнить:

1. Неопасные (нейтральные), непаспортизируемые, их воздействие на ОС не приводит к нарушениям экологической системы. 
2. Опасные, паспортизируемые, содержащие:

a) малоопасные вредные вещества (IV класс опасности);

б) умеренно опасные вредные вещества (III класса опасности);

в) высокоопасные и чрезвычайно опасные вредные вещества, обладающие канцерогенными и мутагенными свойствами (II и I классов опасности).

Отнесение к тому или иному классу опасности осуществляется по критериям и на основании данных паспорта отходов.

VI. ГПО по направлениям возможного использования можно разделить на следующие типы:

1. Пригодные как строительное сырье.

2. Пригодные для извлечения ценных компонентов.

3. Смешанного типа.

Существенное уменьшение объема складированных отходов происходит обычно при использовании ГПО для производства строительных материалов, в то время как извлечение ценных компонентов может оставить объем отходов практически неизменным. Приведенные классификационные признаки предлагаются большинством источников, их можно считать общепринятыми, однако они не позволяют оценить ГПО с точки зрения их вовлеченности в хозяйственный оборот. Предлагается ввести два дополнительных классификационных признака: степень вовлеченности ГПО в хозяйственный оборот и имущественно-правовой статус ГПО для недропользователя.

По степени вовлеченности ГПО в хозяйственный оборот выделим: 1) техногенные минеральные образования - ГПО, которые находятся на начальной стадии вовлечения в хозяйственный оборот (они рассматриваются как потенциальный источник минерального сырья, четкие границы не определены); 2) ТМО (на данной стадии начинается геологическое изучение объекта, которое проводится в определенных границах); 3) ТМ (после того как проведено геологическое изучению техногенного объекта, он признан пригодным для промышленного освоения, а его запасы поставлены на государственный баланс, ТМО получает статус ТМ).

По признаку имущественно-правового статуса ГПО могут быть разделены на четыре категории.

1. ГПО (техногенные минеральные объекты), права собственности на которые принадлежат субъектам, их образовавшим, в соответствии с гражданским законодательством и законодательством об отходах производства и потребления. К этой категории относится часть ГПО, не являющаяся отходами добычи и первичной переработки - отходы топливно-энергетической индустрии, химического и металлургического производств (металлургических переделов в процессе обработки минерального сырья).

2. ГПО (техногенные минеральные объекты), права собственности на которые принадлежат государству в соответствии с законодательством о недрах - отходы действующих горнодобывающих и связанных с ними перерабатывающих производств, образующиеся в процессе добычи и обогащения полезных ископаемых. Права пользования такими ГПО могут определяться двояко:

a) недропользователь обладает самостоятельной лицензией на переработку образуемых им отходов по утвержденному техническому проекту, которая предоставлена наряду с лицензией на право пользования недрами; 
б) недропользователь обладает правом использования отходов в соответствии с разрешительными условиями лицензии на право пользования недрами.

3. ГПО (техногенные минеральные объекты), учтенные государственным балансом по разделу «Техногенное сырье», права собственности на которые принадлежат государству, а право использования которых не предоставлено никому.

4. Брошенные ГПО («бесхозяйные» техногенные минеральные объекты нераспределенного фонда недр), не учтенные государственным балансом по разделу «Техногенное сырье».

В соответствии со ст. 22 Закона РФ «О недрах», недропользователь имеет право использовать отходы своего горнодобывающего и связанного с ним перерабатывающего производства. Использование включает оценку запасов техногенного сырья и их отработку с целью получения ценных компонентов или строительных материалов. Использование отходов горнодобывающего и связанных с ним перерабатывающих производств для получения полезных компонентов допускается при наличии технических проектов их разработки с оценкой НВОС. Не допускается разработка отходов, содержащих повышенные концентрации токсичных элементов или имеющих повышенную радиоактивность.

Таким образом, предлагаемые два классификационных признака дополняют общераспространенную классификацию ГПО и позволяют оценивать их степень вовлеченности в хозяйственный оборот и имущественно-правовой статус как ТМО.

\subsection{4. Типология техногенных минеральных объектов}

В устоявшейся научной терминологии техногенные минеральные объекты (ТМО) - это скопления минеральных образований на поверхности Земли или в пределах открытых горных работ, образовавшиеся в результате отделения их от массива и складирования в виде отходов горного, обогатительного и металлургического (химического) производств. Потенциальная промышленная ценность таких объектов, как правило, не ясна. Для ее установления требуется проведение специальных геологических и технологических работ. Техногенное минеральное образование - скопление на поверхности или в горных выработках, в недрах земли, гидросфере или атмосфере продуктов, созданных человеком, а также минеральных веществ, искусственно отделенных от природного массива или подвергшихся изменению непосредственно в массиве в результате деятельности человека, являющихся отходами [123].

Приведенные определения рассматривают ТМО в основном с геологических позиций. Принимая во внимание управленческий (проектноправовой) аспект под техногенным минеральным объектом будем понимать объект проекта разработки коренного месторождения, искусственно сформированный в процессе производственно-хозяйственной деятельности недропользователя, содержащий скопления минеральных веществ природного и техногенного генезиса, размещенных в отвалах, хвостохранилищах и других специальных сооружениях.

На рисунке 2.3 представлена структурная схема отходов добычи и переработки полезных ископаемых как ТMO. Техногенные минеральные 
объекты обеспечивают локализацию складируемой части минерального вещества извлекаемой горной массы, представляющей собой безвозвратные отходы или техногенные месторождения. Они могут быть представлены как объектами размещения отходов, не являющимися ВМР, так и техногенными месторождениями.

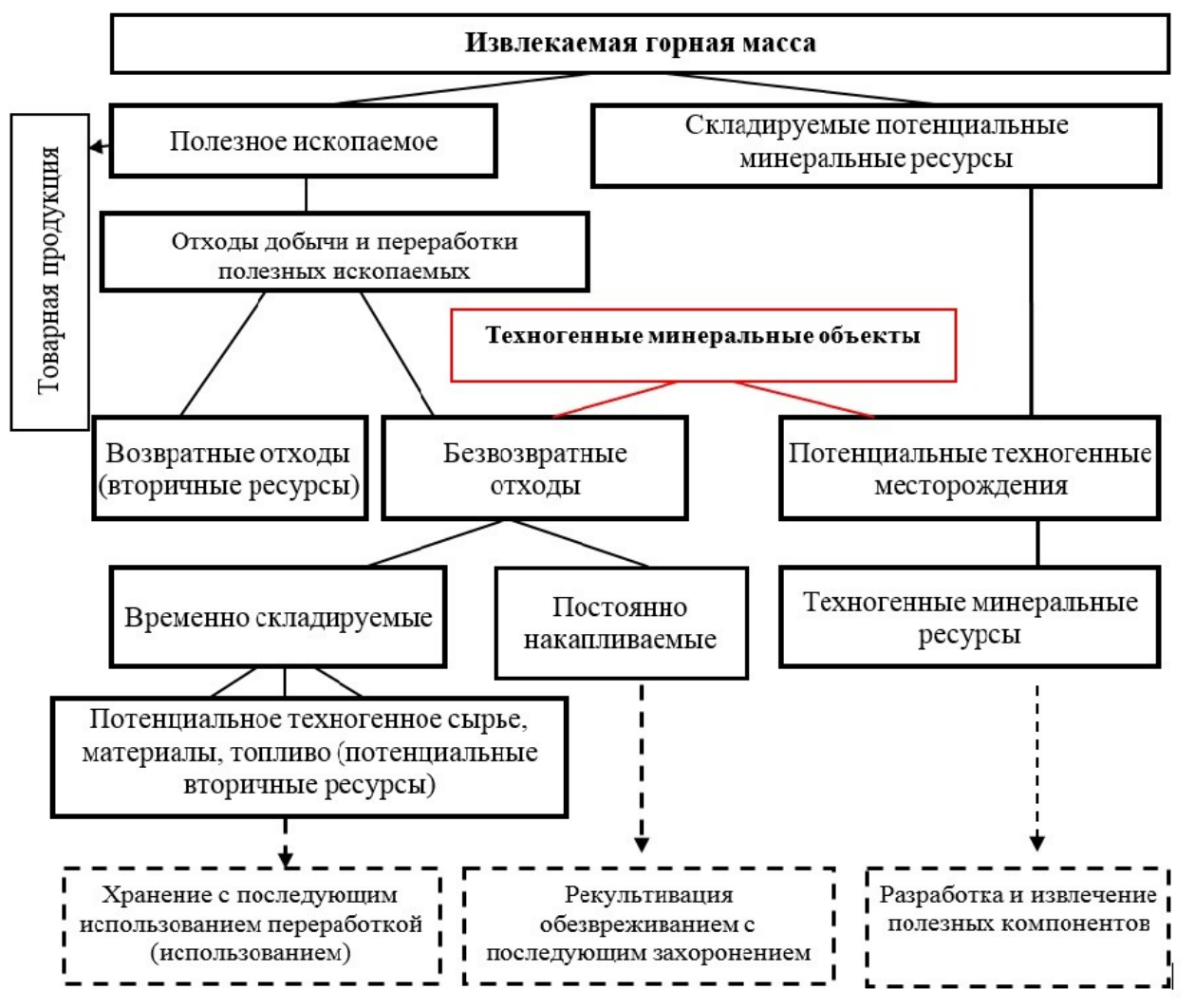

Рис. 2.3. ТМО в структуре потока отходов, образуемых при добыче и переработке полезных ископаемых

Рассмотрим более подробно отдельные аспекты техногенных месторождений. Модельный кодекс «О недрах и недропользовании для государств - участников СНГ» (ст. 246) определяет техногенные месторождения минерального сырья как скопления минеральных образований, горных масс, жидкостей и смесей, содержащих полезные компоненты, являющиеся отходами горнодобывающих и обогатительных производств, находящиеся в отвалах, эфелях, терриконах, прудах-накопителях, разливах и иных специальных формах, а также оставленные (потерянные) в транспортных системах. В табл. 2.3 приведены наиболее известные определения понятия «техногенное месторождение». 
Наиболее известные определения техногенных месторождений

\begin{tabular}{|c|c|}
\hline $\begin{array}{l}\text { Горная } \\
\text { энциклопедия }\end{array}$ & $\begin{array}{l}\text { Техногенное месторождение - это скопление минеральных } \\
\text { веществ на поверхности Земли или в горных выработках, } \\
\text { образовавшееся в результате их отделения от массива и } \\
\text { складирования в виде отходов горного, обогатительного, } \\
\text { металлургического и других производств и пригодное по } \\
\text { количеству и качеству для промышленного использования }\end{array}$ \\
\hline $\begin{array}{l}\text { К. Н. Трубецкой, } \\
\text { С. И. Мормиль, } \\
\text { В. Л. Сальников }\end{array}$ & $\begin{array}{l}\text { Техногенное месторождение - это } \\
\text { образование (объект), по колногенное } \\
\text { содержащегося минерального сырья пригодное для } \\
\text { эффективного использования в сфере материального } \\
\text { производства в настоящее время или в будущем (по мере } \\
\text { развития науки и техники) }\end{array}$ \\
\hline E. B. & $\begin{array}{l}\text { Техногенные месторождения - скопления вторичных } \\
\text { минеральных ресурсов, образовавшихся в результате } \\
\text { складирования отходов производства или потребления и } \\
\text { пригодных по количеству и качеству для разработки и } \\
\text { производства товарной продукции в настоящее время или в } \\
\text { будущем по мере развития науки и техники }\end{array}$ \\
\hline А. Б. Мак & $\begin{array}{l}\text { Техногенные месторождения - скопления минерального } \\
\text { сырья, созданные человечеством в результате } \\
\text { промышленной деятельности }\end{array}$ \\
\hline $\begin{array}{l}\text { В. В. Чайников, } \\
\text { Е. А. Гольдман }\end{array}$ & $\begin{array}{l}\text { Техногенные месторождения - это многотоннажные } \\
\text { скопления отходов добычи и переработки минерального } \\
\text { сырья, использование которых в народном хозяйстве } \\
\text { обеспечивает на данном этапе развития производства } \\
\text { экономический (народнохозяйственный) эффект }\end{array}$ \\
\hline
\end{tabular}

Несмотря на некоторую схожесть определений, авторы по-разному видят составляющие этого термина. Большинство подчеркивает, что само понятие «месторождение» относится к разряду геолого-экономических и в категорию «месторождения» техногенное образование (объект) может быть переведено только в случае его положительной технико-экономической оценки в результате специальных геологоразведочных работ и апробации запасов сырья территориальной комиссией по запасам [123].

Ранее мы отмечали, что техногенные месторождения формируются в основном извлеченными при добыче некондиционными рудами забалансовых запасов, которые учтены ГБЗ и могут быть разработаны в будущем при наступлении определенных экономических и технологических условий, однако формирование таких техногенных объектов не является самоцелью. Поэтому техногенные месторождения будут представлять собой особые случаи хранения TMP для возможного и ожидаемого использования в перспективе. Логика действий определяется тем, что запасы относят к забалансовым и учитывают в ГБЗ на основании ТЭО кондиций, установленных по результатам геологоэкономической оценки коренного месторождения. 
Потенциальное ТМ отличается от обычного объекта размещения отходов (отвала, хвостохранилища и пр., где изначальное требование - безопасное хранение или захоронение отходов) целенаправленностью создания его как перспективного источника ТМР. Это накладывает определенные требования к техническим параметрам ТМ, позволяющим сохранить качество минеральных ресурсов, применять более эффективные системы разработки в будущем, сокращать потери земельных и других природных ресурсов, предотвращать HBOC.

Проблема формирования техногенных месторождений была обозначена еще в советский период. А. М. Гальперин и Ю. И. Кутепов выделяют «целенаправленное формирование техногенных месторождений с оптимальными параметрами, которые выносят ресурсосберегающую и природоохранную функцию в особую категорию, отмечая необходимость учета возможности управления внутренним строением и качеством складируемого материала ТМ» [25]. Таким образом, может осуществляться процесс искусственного воспроизводства МСБ, позволяющий внедрять малоотходные технологические схемы при добыче полезных ископаемых. Этот процесс должен контролироваться соответствующими государственными структурами, отвечающими за состояние данного вида государственного имущества. В настоящее время по этой теме проводятся технологические изыскания (Г. А. Холодняков, Д. Н. Лигоцкий) [139].

Решения о формировании техногенных месторождений как источников TMP должны приниматься исходя из потребностей в конкретном виде минерального сырья, состояния МСБ и прогнозов ее пополнения при отсутствии возможностей покрытия дефицита требуемого ресурса из других источников с учетом экологической нагрузки на территорию. Поэтому формирование техногенных месторождений как техногенных объектов особого рода должно быть всесторонне обосновано, при этом должна быть учтена экономическая целесообразность для недропользователя.

На рисунке 2.4 представлена схема формирования ТМО в рамках действующего горного производства. На схеме выделены два типа ТМО: объекты размещения потенциальных ВМР и объекты скопления отходов, предназначенных для захоронения. В данной схеме не учтены ТMO, представляющие объекты размещения лежалых отходов прошлой производственной деятельности. Таким образом, техногенные месторождения и скопления отходов горного и горно-перерабатывающего производства являются самостоятельными типами ТМО, различающимися целью и технологией формирования, жизненным циклом, правовыми обременениями.

Сформулируем принципы типологии ТМО: 1) принцип баланса вещества извлекаемой горной массы - в общих случаях из недр извлекается не только полезное ископаемое, но и горная масса; 2) принцип комплексности максимальный учет всех полезных компонентов, минеральных веществ, образующих горную массу; 3) принципы технологической возможности, экологической допустимости и экономической целесообразности сохранения или использования всех составляющих горной массы; 4) принцип остатка извлекаемая, но неиспользуемая и несохраняемая часть минерального вещества горной массы становится накапливаемым отходом. 


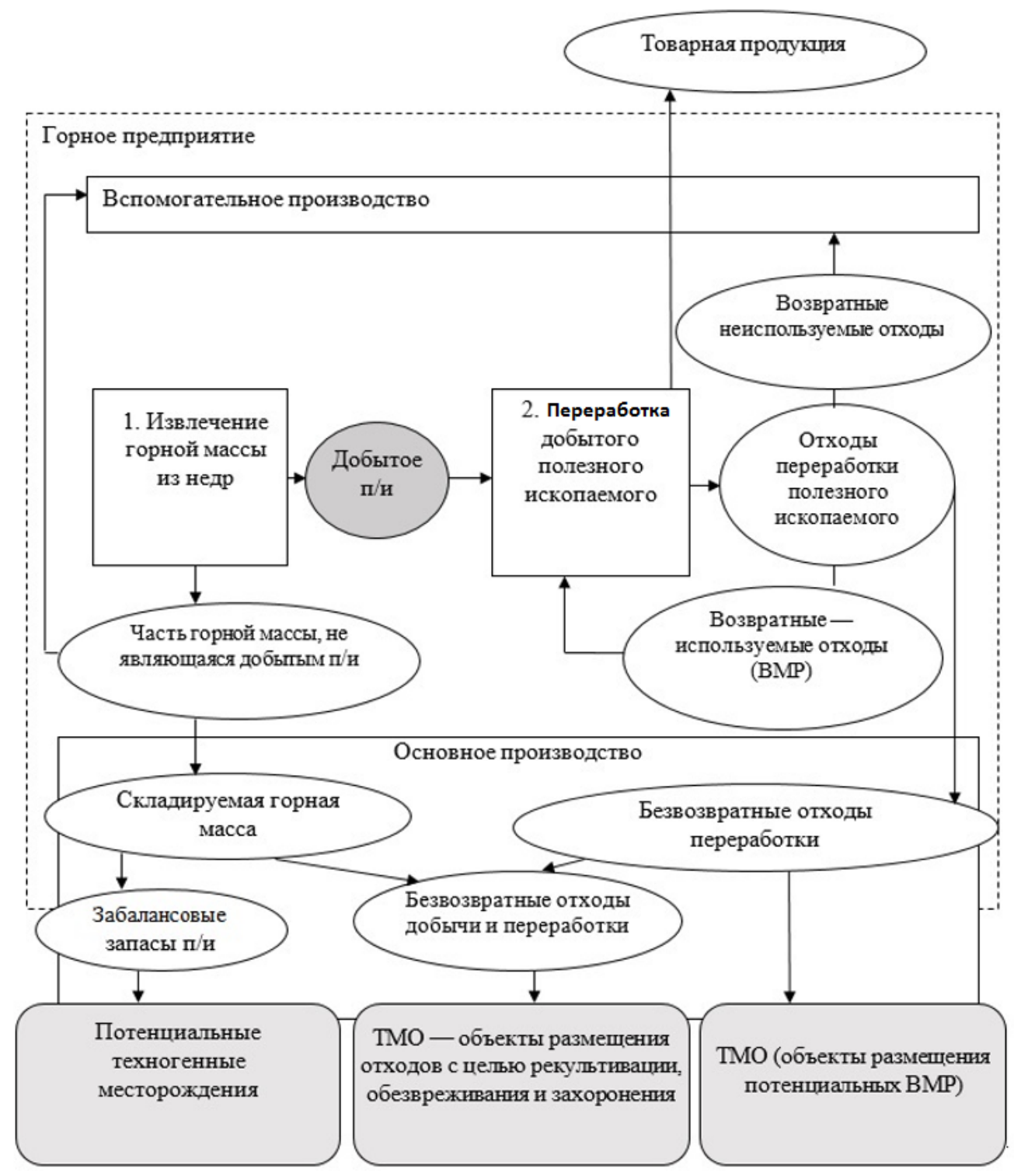

Рис. 2.4. Формирование ТМО на действующем горном производстве

Техногенные минеральные объекты являются сложными объектами управления, что характеризуется: сложностью прогноза и экономической оценки потребительских свойств отходов и ТМР, а также их негативного влияния на ОС и другие виды природопользования; формами прав собственности и многоуровневостью управления различными типами ТМО; значительным влиянием временного фактора, которое проявляется: через вероятное ухудшение качества ТМ, снижение потребности в продукции переработки ТМО и рост потребности в экологической безопасности, несовпадение жизненных циклов ТМО, горного предприятия, субъекта недропользования, сроков предоставления лицензии на право пользования недрами, влияние научно-технического прогресса и развития технологий на жизненный цикл ТМО. 
В таблице 2.4 приведены сравнительные характеристики типов ТМО, формирование которых осуществляется в процессе добычи и первичной переработки полезных ископаемых.

Таблица 2.4

Сравнение типов техногенных минеральных объектов

\begin{tabular}{|c|c|c|c|}
\hline \multirow{3}{*}{$\begin{array}{l}\text { Признаки } \\
\text { сравнения }\end{array}$} & \multicolumn{3}{|c|}{ Техногенные минеральные объекты } \\
\hline & \multirow{2}{*}{$\begin{array}{c}\text { потенциальные } \\
\text { техногенные } \\
\text { месторождения }\end{array}$} & \multicolumn{2}{|c|}{ объекты размещения отходов } \\
\hline & & $\begin{array}{c}\text { временно } \\
\text { складируемых }\end{array}$ & $\begin{array}{c}\text { постоянно } \\
\text { накапливаемых }\end{array}$ \\
\hline $\begin{array}{l}\text { Цель } \\
\text { формирования }\end{array}$ & $\begin{array}{l}\text { Перспективное } \\
\text { использование } \\
\text { (добыча полезных } \\
\text { ископаемых) }\end{array}$ & $\begin{array}{l}\text { Перспективное } \\
\text { использование в } \\
\text { качестве вторичных } \\
\text { ресурсов } \\
\text { (минерального сырья, } \\
\text { материалов, топлива) }\end{array}$ & $\begin{array}{l}\text { Обеспечение } \\
\text { экологической } \\
\text { безопасности }\end{array}$ \\
\hline $\begin{array}{l}\text { Возможность } \\
\text { использовани } \\
\text { я }\end{array}$ & $\begin{array}{l}\text { Определяется на } \\
\text { этапе геолого- } \\
\text { экономической } \\
\text { оценки коренного } \\
\text { месторождения и } \\
\text { (или) } \\
\text { проектирования } \\
\text { горного предприятия }\end{array}$ & $\begin{array}{l}\text { В процессе } \\
\text { функционирования } \\
\text { горнопромышленног } \\
\text { о комплекса }\end{array}$ & $\begin{array}{l}\text { Не выявляется } \\
\text { (возможность } \\
\text { использования за } \\
\text { пределами } \\
\text { жизненного цикла } \\
\text { горнопромышленного } \\
\text { комплекса) }\end{array}$ \\
\hline $\begin{array}{l}\text { Жизненный } \\
\text { цикл объекта }\end{array}$ & $\begin{array}{l}\text { С момента начала } \\
\text { формирования ТМ } \\
\text { до постановки на } \\
\text { кадастровый учет в } \\
\text { Государственном } \\
\text { кадастре } \\
\text { месторождений и } \\
\text { проявлений }\end{array}$ & $\begin{array}{l}\text { С момента начала } \\
\text { размещения отходов } \\
\text { до начала } \\
\text { использования }\end{array}$ & $\begin{array}{l}\text { С момента начала } \\
\text { размещения до } \\
\text { момента ликвидации }\end{array}$ \\
\hline $\begin{array}{l}\text { Учетные } \\
\text { системы }\end{array}$ & $\begin{array}{l}\text { ГБЗ и } \\
\text { Государственный } \\
\text { кадастр } \\
\text { месторождений и } \\
\text { проявлений } \\
\end{array}$ & $\begin{array}{l}\text { Кадастр отходов } \\
\text { производства и } \\
\text { потребления }\end{array}$ & $\begin{array}{l}\text { Кадастр отходов } \\
\text { производства и } \\
\text { потребления }\end{array}$ \\
\hline $\begin{array}{l}\text { Право } \\
\text { собственности } \\
\text { на ресурсы }\end{array}$ & $\begin{array}{l}\text { Сохраняется за } \\
\text { государством }\end{array}$ & $\begin{array}{l}\text { Сохраняется за } \\
\text { недропользователем }\end{array}$ & $\begin{array}{l}\text { Сохраняется за } \\
\text { недропользователем } \\
\text { до окончания } \\
\text { захоронения отходов }\end{array}$ \\
\hline
\end{tabular}

Примечание. Составлено авторами.

Предложенная типология позволяет упорядочить научно-практические представления о разновидностях и целях формирования ТМО при добыче и первичной переработке полезных ископаемых, месте и роли каждого типа 
такого объекта в структуре ТМР разрабатываемого месторождения. Типология позволяет системно подойти к вопросам принятия решений по поводу обращения с отходами горного производства с учетом горно-геологических, экологических, экономических, а также правовых аспектов. Рассматривая с помощью категории ТМО отходы добычи и переработки полезных ископаемых как техногенный минеральный ресурс и одновременно как объект управления этим ресурсом, недропользователи получают возможность более рационально подойти к решению проблемы комплексного использования добываемого минерального сырья. Задача же государства состоит в создании стимулирующих условий посредством стратегического управления подотраслью ТМР.

\section{Выводы по главе 2}

В контексте управления природопользованием, требующим своего научного обоснования, к базовым элементам концепции рационального использования отходов горнодобывающих производств как ВМР можно отнести исторические аспекты, понятийный аппарат и типологию объектов анализа.

Концепция рационального использования ресурсов недр зародилась в советской экономике 1960-х гг. и последовательно развивалась в двух основных своих ипостасях: как концепция интенсификации горнодобывающей промышленности и как горно-экологическая концепция. И тогда, и сейчас эти два концептуальных подхода сосуществуют в научных исследованиях, однако на практике преобладает прагматичное недропользование, когда его рациональность определяется, главным образом, финансовыми потребностями государственного бюджета. В этой парадигме в горнодобывающих регионах неизбежно будут нарастать социально-экологические проблемы и конфликты, что приводит к необходимости их системного решения. Одной из таких проблем являются техногенные отходы, представляющие собой ВМР и одновременно источники загрязнения ОС.

В этой связи актуализируется вопрос дефиниций, полноты и непротиворечивости понятийного аппарата, который должен быть представлен юридически значимыми терминами, позволяющими находить в существующем правовом поле эффективные решения при возникновении конфликта интересов по поводу техногенных объектов и отходов горных производств как товара и источника НВОС. В частности, до сих пор отсутствует нормативное закрепление дефиниции «вторичные минеральные ресурсы» и ряд других. В работе предложено для этих целей определение термина «вторичные минеральные ресурсы», дано определение понятий «потенциальные минеральные ресурсы» и «техногенные минеральные ресурсы», показано их место в структуре запасов полезных ископаемых.

С помощью уравнений баланса вещества горной массы рассмотрены возвратные и безвозвратные отходы добычи и переработки полезных ископаемых, выделены разновидности накапливаемых отходов как объектов управления. Показана принципиальная разница между отходами, относящимися к потенциальным минеральным ресурсам, и не являющимися таковыми безвозвратными отходами с точки зрения их учета и хранения.

Уточнена и дополнена классификация ГПО путем введения двух дополнительных классификационных признаков: степени вовлеченности ГПО в хозяйственный оборот и имущественно-правового статуса ГПО. Рассмотрены 
классы опасности применительно к отходам добычи и переработки полезных ископаемых, критерии их отнесения к тому или иному классу.

Рассмотрено и обосновано содержание понятий «техногенное месторождение» и «потенциальное техногенное месторождение», вопросы их формирования и безопасного размещения. Разработана и представлена типология TMO, показаны ТМО в структуре горного производства и образуемого им потока отходов, сформулированы принципы типологии ТМО. Сделан вывод о том, что использование категории техногенных минеральных объектов позволяет недропользователям рассматривать отходы добычи и переработки полезных ископаемых как техногенный минеральный ресурс и как объект управления этим ресурсом, что позволяет более рационально подойти к решению проблемы комплексного использования добываемого минерального сырья. 


\section{3. ПЕРЕВОД СИСТЕМЫ ГОСУДАРСТВЕННОГО ЭКОЛОГИЧЕСКОГО РЕГУЛИРОВАНИЯ НА МЕХАНИЗМ НАИЛУЧШИХ ДОСТУПНЫХ ТЕХНОЛОГИЙ: ОСОБЕННОСТИ ДЛЯ ПРЕДПРИЯТИЙ ГОРНОДОБЫВАЮЩЕЙ ПРОМЫШЛЕННОСТИ}

\section{1. Законодательная база применения механизма наилучших доступных технологий для борьбы с промышленными загрязнениями в Европейском союзе}

\subsection{1. Комплексный подход к защите окружающей среды от промышленных загрязнений на основе наилучиих доступных технологий в странах Европейского союза}

Одной из основных причин промышленных загрязнений является несовершенство производственных технологий, а непосредственными источниками загрязнений становятся отходы производства. В развитых странах по-разному борются с промышленными загрязнениями ОС, в том числе в сфере добычи и переработки полезных ископаемых. Для нас европейский подход к решению этой проблемы представляет особый интерес, поскольку именно европейскую институциональную модель снижения негативного воздействия промышленных объектов на ОС взяло за основу российское правительство при реформировании системы государственного экологического регулирования промышленных сбросов, выбросов и размещения отходов.

Суть современной европейской модели защиты ОС от промышленных загрязнений заключается в стремлении государства предотвращать образование технологических отходов и последовательно снижать уровень их негативного воздействия. Причем предписывается это делать комплексно и настолько быстро, насколько позволяют технологические инновации, стимулируемые государственной экологической и промышленной политикой. Комплексность подхода к предотвращению и контролю загрязнений подразумевает интегрированную оценку загрязнений по всем видам технологических отходов одновременно.

Технологические отходы (сбросы, выбросы) с позиций природопользования и защиты ОС трактуются как эмиссии (англ. emissions) загрязняющих веществ в атмосферу, водные объекты или почву. Сюда же как следствие сбросов в почву или замкнутые водоемы причисляются размещения твердых технологических отходов или жидких смесей с целью их последующей утилизации либо хранения.

В основе европейской модели лежит идея использования НДТ, системы технологического нормирования эмиссий и получения комплексных разрешений на эксплуатацию установок. Концепция НДТ в рамках этой модели увязывает экологический, технологический и экономический факторы использования установок (объектов НВОС) между собой, позволяя согласовывать интересы участников отношений по поводу функционирования этих объектов и направлять усилия на обеспечение устойчивого развития бизнеса при сохранении природной среды.

На национальном уровне в странах ЕС главными участниками системы отношений являются: государство и его представители в лице компетентных органов; бизнес в лице предприятий промышленности, эксплуатирующих стационарные установки с «грязными» технологиями; неправительственные организации и местные 
сообщества, разделяющие природоохранные ценности. На наднациональном уровне в качестве основного участника выступает макрорегулятор в лице Европейской комиссии. К категории заинтересованных лиц можно отнести международные экологические и промышленные ассоциации, акционеров предприятий загрязнителей ОС, а также разработчиков НДТ.

Термин «наилучшие доступные технологии» (англ. best available techniques) был введен в законодательство Европейского экономического сообщества в 1984 г. Директивой 84/360/ЕЕС в контексте борьбы «без чрезмерных затрат» с загрязнением атмосферного воздуха крупными промышленными установками (Best Available Techniques Not Entailing Excessive Costs - BATNEEC) [190].

В 1996 г. Европейская комиссия придала понятию НДТ смысловую определенность, которая незыблемо сохраняется по настоящее время. Была принята Директива 96/61/EC «О комплексном предотвращении и контроле загрязнений» (Integrated Pollution Prevention and Control - IPPC), которая ввела общую систему экологического регулирования деятельности промышленных установок-загрязнителей на основе НДТ [191]. Ею были нормативно закреплены дефиниции «загрязнение», «установка», «предельные значения выбросов», «стандарт качества окружающей среды», «компетентный орган», «разрешение на эксплуатацию установки или ее части», «эмиссия» ${ }^{40}$ и др. Также были указаны критерии определения НДТ для конкретной ситуации при выборе из имеющихся технологических альтернатив с учетом вероятных затрат и выгод. Составляющие самого понятия «наилучшие доступные технологии» были определены следующим образом (пункт 11 статьи 2, 96/61/ЕС) [191]: «mехнологии» - методы, техники, способы проектирования, строительства, обслуживания, эксплуатации и вывода из эксплуатации установки; «доступные»» - позволяющие внедрять технологии в соответствующем секторе промышленности, когда это экономически и технически возможно; наилучшие» - наиболее эффективные в достижении высокого общего уровня защиты ОС без предписания использовать конкретные технологии.

На уровне ЕС начался информационный обмен в области НДТ с одновременной разработкой справочников НДТ первого поколения ${ }^{41}$. Для организации обмена информацией и координации работ по созданию справочных документов НДТ в 1997 г. было учреждено Европейское бюро по комплексному предупреждению и контролю загрязнений $\left(\mathrm{EIPPCB}^{42}\right)$. Характерно, что Директива 96/61/ЕС предусматривала отмену Директивы 84/360/ЕЕС лишь спустя одиннадцать лет после вступления в силу, т. е. в 2007 г. (пункт 3 статьи 20 96/61/ЕС). Таким образом, Директива 96/61/ЕС положила начало развитию современной концепции комплексного предотвращения и контроля загрязнений в Европейском союзе.

\footnotetext{
40 Термин «эмиссия» (emission) определен как «выброс веществ, вибраций, тепла или шума от источника в установке в воздух, воду или почву», он охватывает сбросы, выбросы и размещения отходов.

41 Боравская Т. В. Обращение с отходами - сопоставительный анализ процесса сближения законодательства России и Европейского Союза // РОСПРОМЭКО: сайт. URL: $\quad$ http://www.rospromeco.com/zakonodatelstvo/27-analytic/zakonodatelstvo/66zakonodatelstvo-8 (дата обращения: 16.08.2019).

42 European Integration Pollution Prevention Control Bureau (Европейское бюро по комплексному предупреждению и контролю загрязнений).
} 
В России сложилась традиция именовать применяемый в странах ЕС подход к борьбе с промышленными загрязнениями на основе НДТ «принципом» НДТ либо «принципами» НДТ ${ }^{43}$. При этом под принципами НДТ понимают пять аспектов $\left.{ }^{44}: 1\right)$ обеспечение защиты ОС наиболее эффективным способом по сравнению с остальными; 2) готовность разработанной технологии к внедрению; 3) экономическая эффективность и техническая реализуемость внедрения; 4) учёт положительного опыта использования данной технологии на конкретных предприятиях; 5) совокупность процессов проектирования, строительства предприятия, использование технологий, вывод предприятия из эксплуатации по окончании жизненного цикла.

Следует отметить, что в самой Директиве 96/61/EC речь идет не о принципах НДТ, а о принципах контроля установок-загрязнителей, о чем более подробно будет сказано далее. На наш взгляд, концептуально НДТ выступают, скорее, не как принципы, а как механизм снижения уровня эмиссий загрязняющих веществ в отрасли, в основе которого лежит идея «принудительного» распространения лучших с экологической точки зрения практик внедрения инновационных решений технологическими лидерами отрасли. Внутренним стимулом механизма НДТ, мотивирующим владельцев экологически «грязных» установок переходить на лучшие практики с целью снижения эмиссий для достижения растущего уровня качества ОС, является необходимость получения у компетентных органов комплексных природоохранных разрешений.

Европейское законодательство предусматривает, что для получения таких разрешений предприятия основных отраслей, оказывающих значительное воздействие на ОС, должны: применять НДТ либо платить за превышение технологических показателей НДТ; предотвращать крупномасштабные и трансграничные загрязнения; эффективно использовать воду, энергию, сырье; снижать риски возникновения аварий и минимизировать их последствия; осуществлять мониторинг эмиссий загрязняющих веществ; рекультивировать площадки после прекращения деятельности установок; для новых предприятий уровни эмиссий (выбросов загрязняющих веществ, сбросов сточных вод, образования отходов) должны соответствовать НДТ; для действующих предприятий предусматривается постепенное сокращение эмиссий до достижения уровня НДТ с разработкой соответствующих планов; если национальный стандарт качества ОС требует выполнения более строгих условий, чем определяемые НДТ, то разрешение должно содержать требования по дополнительным мерам обеспечения соответствия стандартам качества.

Следует выделить два важнейших, на наш взгляд, аспекта результативности действия механизма НДТ в европейской модели экологического регулирования: способность бизнеса внедрять НДТ без ухудшения экономических показателей и способность компетентных органов объективно осуществлять контроль установок и

\footnotetext{
${ }^{43}$ См., напр., Распоряжение Правительства РФ от 19 марта 2014 г. № 398-р «О комплексе мер, направленных на отказ от использования устаревших и неэффективных технологий, переход на принципы наилучших доступных технологий и внедрение современных технологий // ГАРАНТ.PУ: сайт. URL: https://www.garant.ru/products/ipo/prime/doc/70519522/ (дата обращения: 11.08.2019).

44 О внедрении НДТ в промышленности // Правительство России: официал. сайт. URL: http://government.ru/info/15384/ (дата обращения: 15.08.2019).
} 
оценивать качество заявок на получение природоохранных разрешений, руководствуясь этим при выдаче разрешений.

Для отражения эволюции европейского законодательства в части борьбы с вредными воздействиями промышленных производств на ОС сделаем краткий обзор основных правовых нормативных актов, регулирующих обращение с отходами и промышленные эмиссии, в хронологическом порядке их принятия.

\subsection{2. Развитие базового законодательства об отходах и промышленных эмиссиях в Европейском союзе}

Общие цели Европейского сообщества в сфере обращения с отходами были сформулированы в Стратегии ЕС по обращению с отходами, опубликованной в 1989 г. В 1997 г. Совет ЕС пересмотрел ранее принятую Стратегию и подтвердил, в частности, что предотвращение образования отходов является первоочередной задачей при обращении с ними, а их повторное использование должно быть предпочтительнее использования для получения энергии, поскольку это лучше с точки зрения экологии ${ }^{45}$.

В 2004 г. была принята Директива 2004/35/ЕС Европейского парламента и Совета ЕС «Об экологической ответственности в отношении предотвращения и устранения ущерба окружающей среде», в которой основополагающим принципом была названа финансовая ответственность оператора, деятельность которого нанесла ущерб ОС или создала неизбежную угрозу такого ущерба. Этим преследовалась главная цель - побудить операторов принимать практические меры по минимизации рисков для ОС с использованием процедур оценки риска. Чтобы механизмы ответственности были эффективными, загрязнители должны быть идентифицируемыми, а ущерб - поддающимся количественной оценке. Наличие рисков должно определяться с учетом характеристик почвы, типа и концентрации вредных веществ. Директива 2004/35/СЕ применялась по отношению к ущербу, нанесенному ОC профессиональными действиями операторов установокзагрязнителей, в том числе при обращении с отходами, включая эксплуатацию полигонов их захоронения.

В 2006 г. была принята новая Рамочная директива 2006/12/ЕС «Об отходах» взамен устаревшей Рамочной директивы 75/442/EЕС «Об отходах», действовавшей с 1975 г., которая установила законодательную базу для обращения с отходами в Сообществе, определила, в частности, понятия «отходы», «утилизация», «удаление» и прояснила различие между отходами и неотходами, утилизацией и удалением. Были сформулированы основные требования к обращению с отходами и сделан акцент на предотвращении их образования. Статья 2 Директивы 2006/12/ЕС гласила, что из сферы ее действия наряду с радиоактивными отходами исключаются отходы, возникающие в результате разведки, добычи, обработки и хранения минеральных ресурсов, а также разработки карьеров [193].

В январе 2008 г. Европейским парламентом и Советом ЕС была принята Директива 2008/1/EC «О комплексном предотвращении и контроле загрязнений

\footnotetext{
45 Директива Европейского Парламента и Совета ЕС об отходах и отмене ряда Директив // wikiwaste.ru: сайт. URL: https://wikiwaste.ru/direktiva-evropejskogo-parlamenta-i-sovetaevropejskogo-soyuza-ob-othodah-i-otmene-ryada-direktiv/ (дата обращения: 17.08.2019).
} 
(кодифицированная версия)» [194], которая модернизировала содержание Директивы 96/61/EC [191]. В текстовую часть предыдущей директивы были внесены поправки, более тесно увязывающие концепцию НДТ с целями государственной экологической политики, направленной на обеспечение устойчивого развития за счет разумного управления природными ресурсами. Подчеркивалась необходимость соблюдения принципа «загрязнитель платит». Комплексный подход к предотвращению и контролю загрязнений предписал операторам установок-загрязнителей учитывать экологические аспекты. Эти аспекты доводятся до сведения государственного компетентного органа, ответственного за реализацию положений директивы, чтобы до выдачи разрешения на эксплуатацию установки тот мог удостовериться в принятии оператором всех превентивных мер по борьбе с загрязнениями. Компетентный орган выдает комплексное разрешение с условиями, которые гарантируют, что объект соответствует требованиям директивы, в противном случае отказывает в его выдаче. Разрешение помимо прочего содержит требования к мониторингу эмиссий с указанием методологии и частоты соответствующих измерений, процедуру оценки и обязательство оператора предоставить компетентному органу необходимые данные для проверки объекта на соответствие разрешению.

Директива 2008/1/ЕС предписала обеспечить публичность информации о работе эксплуатируемых установок и их потенциальном воздействии на ОС, равно как и публичность информации по заявкам на выдачу разрешений на новые установки или внесение существенных изменений в эксплуатируемые установки. В соответствии с Директивой 2008/1/ЕС предельные значения эмиссий, их параметры или эквивалентные технические меры должны обеспечиваться посредством НДТ с учетом технических характеристик установки, ее географического положения и местных условий ОС без предписания использования конкретного метода или технологии.

Была введена отдельная статья о соблюдении операторами установок требований разрешения на их эксплуатацию. Операторы (предприятия) должны регулярно предоставлять компетентному органу информацию о результатах мониторинга эмиссий и незамедлительно сообщать о произошедшем инциденте или аварии. Кроме того, операторам предписано оказывать представителям компетентного органа всю необходимую помощь при проведении любых проверок установок, отбора образцов и сбора данных для достижения указанных в директиве целей. Директива дополнительно включила отдельную статью с общими принципами, регулирующими основные обязанности оператора установки. Один из принципов гласит, что государство должно обеспечить, чтобы компетентные органы добились такой эксплуатации установок, когда для борьбы с загрязнениями превентивно принимаются все необходимые меры, включая использование НДТ. Директива 2008/1/ЕС действовала до 7 января 2014 г. и была отменена Директивой 2010/75/ЕС [196].

19 ноября 2008 г. Европейским парламентом и Советом ЕС была принята новая Рамочная директива 2008/98/ЕС «Об отходах» [195], которая пересмотрела некоторые положения Директивы 2006/12/ЕС и отменила ее. В преамбуле новой директивы отмечено, что первой целью любой политики в отношении отходов должно быть сведение к минимуму негативных последствий их образования и управление ими таким образом, чтобы не причинять вред здоровью людей и не наносить ущерб ОС. Указано, что директива должна 
помочь приблизить ЕС к «обществу по переработке отходов», которое стремится избегать их образования, а образовавшиеся использовать в качестве pecypca.

В соответствии со статьей 2.2 (А) из сферы действия Директивы 2008/98/ЕС были исключены отходы, возникающие в результате разведки, добычи, обработки и хранения минеральных ресурсов и работы карьеров, на которые распространяется Директива 2006/21/ЕС «Об управлении отходами добывающих отраслей» [192]. Ответственность за управление отходами, согласно статье 15 , возлагается на любого производителя или собственника отходов. Производитель или собственник должен осуществлять обработку отходов самостоятельно, через торгового посредника или специальную организацию, занятую в сфере обращения с отходами. Если физическим или юридическим лицам передаются для предварительной обработки отходы первого производителя или собственника отходов, то по общему правилу с них не снимается ответственность за проведение операций полного восстановления или утилизации. Европейская комиссия в соответствии со статьей 29 создает систему обмена информацией об успешном опыте предотвращения образования отходов и вырабатывает руководящие принципы для поддержки государств членов ЕС в их деятельности по разработке программ по предотвращению их образования. В приложениях к Директиве 2008/98/ЕС приведены перечни операций утилизации и восстановления отходов.

24 ноября 2010 г. Европейским парламентом и Советом ЕС была принята Директива 2010/75/EC «О промышленных эмиссиях» [196], упоминаемая как Директива IED, которая отменила Директиву 2008/1/EC и несколько других директив ЕС об узкоотраслевых отходах и выбросах, а также об ограничениях на выбросы из крупных установок для сжигания.

Появление данной директивы было вызвано назревшей необходимостью переработки с единых позиций национальных законодательств стран - членов ЕС по ограничению эмиссий загрязняющих веществ промышленными установками в таких сферах деятельности, как энергетика, производство и обработка металлов, химическая и минеральная промышленность, управление установками по переработке отходов и некоторых других. С принятием Директивы IED европейская система комплексного предотвращения и контроля загрязнений (IPPC) вышла на новый уровень своего развития.

Статья 11 Директивы IED определяет, что государства EC должны принять все необходимые меры, чтобы экологически опасные промышленные установки эксплуатировались в соответствии с общими принципами, регулирующими обязанности операторов установок, среди которых с точки зрения целей нашего монографического исследования необходимо выделить четыре общих принципа: (а) для борьбы с загрязнениями используются все превентивные меры; (b) на установках применяются НДТ; (c) предотвращается, насколько это возможно, образование отходов; (d) образуемые отходы в порядке очередности подготавливаются для повторного использования, перерабатываются или, где это технически и экономически невозможно, утилизируются, чтобы избежать или сократить любое воздействие на ОС.

Директива IED подтвердила, что комплексность остается важнейшим принципом борьбы с загрязнениями, включая управление отходами, повышение энергоэффективности и предотвращение аварий. Принимается во внимание 
также то, что предотвращение и контроль выбросов в воздух, воду или почву по отдельности может способствовать переносу вредных веществ между компонентами ОС, а не защищать ее как единое целое.

В соответствии с директивой, обеспечение комплексности и, соответственно, высокого общего уровня защиты ОС должно достигаться следующими основными мерами: установлением стандартов качества ОС в виде перечня единых экологических требований к стационарным промышленным установкам; применением на промышленных установках НДТ и оценки экологической эффективности по уровням эмиссий и уровням потребляемых установками материальных ресурсов для предупреждения и снижения загрязняющих воздействий и ресурсосбережения; строгой регламентацией процедур получения и продления экологических разрешений на эксплуатацию промышленных установок.

Статья 12 Директивы IED подробно описывает структуру заявки предприятия на получение у компетентного органа экологических (природоохранных) разрешений на эксплуатацию стационарных установок, осуществляющих эмиссии загрязняющих веществ в ОС. Условия разрешения устанавливаются на основе применения НДТ. Директивой установлены правила предотвращения загрязнений от деятельности установок, а также правила предотвращения или сокращения эмиссий загрязняющих веществ в воздух, воду и почву, предотвращения образования отходов. Введены так называемые обязательные общие правила (general binding rules) в отношении предельных значений эмиссий. Их выполнение становится одним из главных условий выдачи экологических разрешений на эксплуатацию установок. Предельное значение эмиссии означает массу, выраженную определенными параметрами, концентрацией и/или уровнем эмиссии, которые не могут быть превышены в течение одного или нескольких периодов времени [196, 3 (5)].

В статье 3 (13) Директивы IED указывается, что «уровни эмиссий, связанные с НДТ» (emission levels associated with the best available techniques BAT-AEL), означают диапазон уровней эмиссий, полученных в нормальных условиях эксплуатации установок с использованием НДТ или комбинации НДТ, выраженных в виде среднего значения за определенный период времени. Директива уточнила виды деятельности по категориям (отраслям), к которым применяются пороговые ограничения производственной мощности или объема производства. Значительно расширена по сравнению с версией в Директиве 2008/1/ЕС такая категория видов деятельности, как управление отходами, которая включила, в частности: удаление или утилизацию опасных отходов с производительностью установок, превышающей десять тонн в день, с учетом таких действий, как биологическая очистка, физико-химическая обработка и др.; удаление неопасных отходов с производительностью установок, превышающей пятьдесят тонн в день, с учетом таких видов действий, как биологическая очистка, обработка шлаков и золы и др.; временное хранение опасных отходов за исключением временного размещения на площадке для образования отходов; подземное хранение опасных отходов вместимостью более пятидесяти тонн.

В Директиве IED, в отличие от предыдущей Директивы 2008/1/EC, конкретизированы список загрязняющих веществ, включающий одиннадцать позиций, и критерии для определения НДТ, которые в 2008/1/ЕС квалифицировались как «соображения, которые следует принимать во внимание 
при определении НДТ». Само содержание понятия «наилучшие доступные технологии» в Директиве IED (2010) не претерпело изменений по сравнению с определением в Директиве IPPC (1996): наилучшие доступные технологии наиболее эффективная и передовая стадия развития производственной деятельности и методов эксплуатации промышленных установок, которая свидетельствует о практической пригодности определенных технологий создавать основу для обеспечения (непревышения) предельных значений эмиссий и выполнения других условий экологического разрешения с целью предотвращения и, если это невозможно, снижения вредного воздействия эмиссий на ОС в целом [196, 3 (10)].

При этом поясняется, что: «(а) «технология» - используемая технология, методы, способы проектирования и сборки установки, ее обслуживания, эксплуатации и вывода из эксплуатации; (б) «доступная» технология разработана и производится в масштабе, позволяющем применять эту технологию в отрасли промышленности с учетом экономической и технической целесообразности, затрат и выгод (условия жизнеспособности viable conditions), если технология доступна для оператора независимо от того, в каком государстве ЕС она производится и используется; (в) «наилучшая» технология наиболее эффективная в достижении высокого общего уровня защиты окружающей среды в целом».

Большое место Директива IED отвела вопросам разработки справочных документов по НДТ (справочников НДТ), обновлению системы создания этих информационно-методических документов. Директивой определено, что для выявления НДТ в установленных видах деятельности и устранения дисбалансов в отношении уровней выбросов от промышленных установок должны составляться, рассматриваться и при необходимости обновляться справочные документы по HДT $\left(B R I F^{46}\right)$, которые в IED обозначаются как документированный результат обмена информацией по определенным видам деятельности, описывающий используемые технологии в области применения BRIF, существующие уровни эмиссий, методы определения НДТ и новые технологии.

Для составления, рассмотрения и обновления справочных документов по НДТ статья 13 Директивы IED (2010/75/EU) предписала Европейской комиссии организовать и на регулярной основе поддерживать обмен информацией между государствами - членами ЕС, заинтересованными в НДТ отраслями промышленности и неправительственными организациями, содействующими защите ОС с использованием НДТ. Эту работу возглавило созданное в 1997 г. в Севилье (Испания) Европейское бюро по комплексному предупреждению и контролю загрязнений (ЕIPPCB). После вступления в силу Директивы IED Европейское бюро IPPC стало готовить справочные документы НДТ второго поколения.

В качестве самостоятельного документа директивой введено заключение по HДT, включающее те части BRIF, в которых рассматриваются различные аспекты НДТ: их описание, области применения, уровни эмиссий, производственный экологический мониторинг, уровни потребления ресурсов и,

46 Best available techniques REFerence document, Справочный документ по НДТ (ИТСНДТ). 
где это необходимо, меры по восстановлению производственных площадок с установками [196, 3 (12)]. В принятии решений по заключениям НДТ участвует комитет, сформированный в соответствии со статей 75 (1) IED из представителей всех государств - членов ЕС для оказания помощи Комиссии по вопросам реализации Директивы IED. Непосредственно составлением, анализом и рецензированием документов BREFs занимаются технические эксперты в составе специальных технических рабочих групп (TWG) и подгрупп.

Важной особенностью обновленного подхода к разработке справочных документов по НДТ, придавшей процессу создания BREF дополнительную оперативность и новое качество, стало формирование открытой системь информационного обмена и подвижной экспертной среды. Открытость и оперативность достигается за счет создания: 1) доступного для неограниченного круга посетителей веб-сайта ЕІРРСВ с нормативно-правовыми документами по НДТ, текстами действующих и разрабатываемых BREFs, планами работы по их составлению и анализу $\left.{ }^{47} ; 2\right)$ специализированного инструмента обмена информацией в виде веб-приложения BATIS ${ }^{48}$ для разработчиков BREF и участвующих в его обсуждении экспертов; 3) действующего на постоянной основе форума, участниками которого могут быть представители всех заинтересованных в НДТ сторон: государств - членов EC, предприятий различных отраслей промышленности, неправительственных организаций и сообществ.

$\mathrm{B}$ соответствии с IED при обмене информацией должны рассматриваться: (a) эксплуатационные характеристики установок и технологий с точки зрения средних значений (краткосрочных и долгосрочных) эмиссий, где это уместно, и соответствующие эталонные условия, потребление и характер сырья, потребление воды, использование энергии и образование отходов; (б) используемые в установках технологии, их мониторинг, межсредовые загрязнения, экономическая и техническая целесообразность (жизнеспособность), развитие технологий; (в) НДТ и новые технологии, выявленные после рассмотрения пунктов (а) и (б).

Директива IED усилила значение мониторинга и инспектирования установок, проведение которых в соответствии с IED является важной функцией государств членов ЕС. В статье 14 в качестве обязательного условия получения экологического разрешения на эксплуатацию установки перечисляется ряд требований, касающихся мониторинга выбросов и управления образующимися отходами, включая указание методологии измерения, порядка оценки эмиссий, периодичности замеров, составления сводки мониторинга.

Статья 20 требует, чтобы все установки охватывались планом экологической инспекции на национальном, региональном или местном уровнях. На основе плана компетентный орган должен составлять программы регулярных экологических инспекций. Период посещения площадок с установками различного типа должен основываться на оценке экологических рисков каждого из типов, не превышая год для установок с наибольшим риском и три года для установок с наименьшим риском. После каждого посещения объекта компетентный орган подготавливает отчет, где отражает соответствие установки условиям комплексного экологического разрешения.

47 Веб-сайт EIPPCB (http://eippcb.jrc.ec.europa.eu) представляет собой основной инструмент для распространения BREF.

${ }^{48}$ Best Available Techniques Information System, Информационная система по НДТ. 
Таким образом, опорным инфраструктурным элементом системы создания справочных документов по НДТ нового поколения стало появление открытой системы информационного обмена, не только упрощающей работу технических экспертов в составе специальных технических рабочих групп, но и, что немаловажно, обеспечивающей доступ к проектам НДТ и заявкам на получение экологических разрешений всех заинтересованных лиц. Особое значение Европейская комиссия придает форуму - первичному элементу системы информационного обмена. Он был создан 16 мая 2011 г. отдельным Решением Европейской комиссии 2011/C146/03 «Форум обмена информацией по НДТ в соответствии с законодательством о промышленных эмиссиях» [188]. Главными целями форума провозглашены: взаимодействие экспертов, анализ ими предлагаемого содержания справочных документов по НДТ (BREF), публикация результатов информационного обмена.

\subsection{3. Регламентация содержания справочных документов по наилучшим доступным технологиям и определение экологических показателей для идентификации наилучших доступных технологий}

После создания форума последовало еще одно Решение Европейской комиссии 2012/119/EU от 10 февраля 2012 г. по реализации требований Директивы о промышленных эмиссиях в части составления справочных документов по НДТ (BREF) и выполнения требований статьи 13 IED об организации обмена информацией [189]. Текст этого решения включает шесть глав, в которых с высокой степенью детализации описываются и регламентируются следующие аспекты: 1) цель и процедуры оформления BREF (порядок составления, рассмотрения и проверки); 2) структура и содержание BREF; 3) состав заключения по НДТ, уровни эмиссий и других экологических характеристик; 4) организация обмена информацией по НДТ (роль форума, создание и задачи технических рабочих групп, инструменты обмена информацией); 5) сбор данных для разработки BREF, оцениваемые экологические показатели и эксплуатационные данные установок; 6) обеспечение качества оформления BREF и обзоры BREFs.

Законодательно определено, что общей целью BREFs является выявление НДТ и устранение дисбалансов в странах — членах ЕС в отношении уровней эмиссий основных промышленных загрязнителей природной среды. Европейской комиссией установлено, что BREFs должны служить движущей силой для улучшения промышленных экологических показателей. Сами BREFs представляют собой унифицированные документы, структура которых стандартизирована, а содержание каждого из них отражает специфику рассматриваемого промышленного сектора или отрасли (industry sector) области распространения BREF. Для своевременного учета апробированных технологических инноваций BREFs должны обновляться (актуализироваться) не позднее чем через восемь лет после выхода очередной версии.

Решение 2012/119/EU определяет два вида BREFs: горизонтальные и вертикальные. Горизонтальные BREF представляют собой справочники по НДТ межотраслевой ориентации, которые могут охватывать несколько отраслей или промышленных секторов, а вертикальные BREFs - это справочные документы НДТ отраслевого уровня, которые включают базовые НДТ, применимые на всех 
предприятиях отрасли, и специальные НДТ, применимые на отдельных стадиях технологического процесса. B BREFs раскрываются потенциальные экологические преимущества от внедрения НДТ и оцениваются экономические показатели НДТ, такие как капитальные и эксплуатационные затраты, обеспечивающие функционирование установок, а также удельный расход сырья и материалов при производстве продукции.

Одно из центральных мест в документе 2012/119/EU отводится заключениям по НДТ, в которых содержатся: вся существенная информация по НДТ, сосредоточенная в одном разделе BREF, включая уровни эмиссий НДТ, частота и методы мониторинга установок, виды деятельности, на которые НДТ распространяется. Некоторые заключения структурно могут иметь групповой характер, объединяя несколько отдельных (индивидуальных) заключений по НДТ по общим признакам, таким как экологические проблемы или этапы производственного процесса.

Индивидуальные заключения по НДТ должны отражать экологическую эффективность НДТ, которая может характеризоваться тремя типами показателей воздействия НДТ на ОС: уровнем эмиссии, уровнем потребления и не связанными с ними показателями, например уровнем, отражающим эффективность борьбы с загрязнением. Отдельные заключения по НДТ не содержат показателей экологической эффективности, если технологии не связаны с воздействием на ОС, например НДТ по мониторингу или системам экологического менеджмента.

Уровни эмиссий индивидуальных НДТ (BAT-AEL) оцениваются по усредненным (средним ежедневным, еженедельным и т. д.) диапазонам значений измеряемых единичных показателей (например, температуры, давления). В зависимости от имеющейся информации уровни эмиссий могут выражаться двумя способами $[189,(3.3 .1)]: 1)$ в виде кониентращии (масса загрязняющего вещества, отнесенная к единице объема эмиссии, — выброса газов или сброса технологических сточных вод; это наиболее распространенный способ выражения уровней эмиссий, но для сопоставимости показателей необходимо наличие эталонных условий и периодов усреднения, что позволяет выявлять колебания и пиковые выбросы и определять значения экологических показателей в моменте; 2) в виде удельных эмиссий (масса выброса загрязняющего вещества, отнесенная к массе произведенного продукта или к массе использованного сырья); показатели удельной эмиссии предпочтительнее показателей концентрации в случаях, когда концентрация загрязняющих веществ возрастает, например, если для сокращения объемов сточных вод и экономии энергии перевести производство на систему замкнутого водооборота; удельные эмиссии позволяют сравнивать экологические характеристики установок независимо от различий в объемах производства, смешивания или разбавления.

В ряде случаев более предпочтительными для отражения в индивидуальных заключениях по НДТ уровней экологической эффективности могут оказаться уровни потребления как показатели потребления промышленной установкой ресурсов (сырья, воды, энергии) и образования отходов. Соответствующие НДТ уровни потребления предпочтительнее измерять отношением потребляемой массы (сырья), объема (воды), энергии (тепловой, электрической) к массе произведенного продукта (кг/т, м³/т) или произведенной энергии (МДж/т) в соответствующих единицах измерения. 
Применительно к отходам, образуемым НДТ, уровни экологической эффективности рекомендуется выражать отношениями массы отходов к массе произведенной продукции (например, в кг/т). Они также могут быть выражены другими показателями, например, в виде отношения массы образовавшихся отходов к массе использованного сырья (например, в кг/т). Следует отметить, что во многих случаях в заключениях по НДТ указывается, что отходы следует минимизировать в источнике их образования и изыскивать методы рециклирования [118].

Описываемые в BREF технологии считаются наиболее подходящими для идентификации в качестве НДТ, если их применение позволяет в подтверждаемой форме снижать потребления сырья, воды или энергии, предотвращать или уменьшать образование отходов и при этом охватывает меры по предотвращению или ограничению экологических последствий аварий и инцидентов на установках.

В заключении по НДТ указываются потенциальные экологические выгоды (польза), которые могут быть получены при внедрении на предприятии НДТ. Каждое заключение имеет статус отраслевого документа, который утверждается Исполнительным решением Комиссии и публикуется в официальном журнале Европейского союза ${ }^{49}$.

Одним из важных с практической точки зрения аспектов BREF, который во многом определяет характер заключений по НДТ и качество BREF в целом, является сбор первичной информации. Например, Решение 2012/119/EU ставит в зависимость от собранных данных принятие решения об использовании в BREF концентраций или удельных эмиссий либо их сочетания в качестве показателей экологической эффективности, оставляя это на усмотрение технических рабочих групп.

С позиции технических рабочих групп как разработчиков НДТ сбор данных - это внутренняя функция системы обмена информацией, которая обеспечивает входной поток данных о доступных технологиях. Основной источник данных предприятия, которые содержат промышленные установки и являются пользователями BREF. После разработки или обновления BREF (справочников НДТ) образуется выходной поток данных в виде заключений по НДТ, содержащих нормативные ограничения на эмиссии и другие экологические характеристики, касающиеся установок. В такой модели взаимодействия предприятие (оператор установки) является заинтересованной стороной, поскольку от параметров данных и их значений зависит успешность и затратность получения экологических разрешений на эксплуатацию установки. По этой причине содержание входной информации и получение данных становятся одним из факторов эффективности экологического регулирования на основе НДТ и представляют практический интерес не только для разработчиков НДТ, но и для предприятий, попадающих в сферу действия BREF. Решение 2012/119/EU директивно установило правила сбора и представления данных для составления и проверки BREF, подробному описанию которых отведена отдельная глава документа.

Чтобы сформировать объективное представление об экологических параметрах используемых технологий в сопоставимых видах деятельности, при разработке BREFs требуется проанализировать большой массив технических данных, позволяющих определить уровни эмиссий и потребления материальных ресурсов на единицу продукции по всей цепочке технологических переделов в нормальных

\footnotetext{
${ }^{49}$ Official Journal of the European Union.
} 
условиях эксплуатации установки. Собираемые данные должны достоверно отражать потребление каждой установкой энергии, воды, сырья и материалов, характерный для нее уровень выбросов вредных веществ в воздух и воду, уровень образования отходов, а также, где это уместно, уровень шума и запаха. При этом указываются входные и выходные параметры производственных процессов и подпроцессов, что позволяет выявить наиболее экологически значимые подпроцессы и рассмотреть варианты переработки и повторного использования отходов производства.

Для выявления НДТ могут потребоваться не только эксплуатационные параметры установок и агрегированные данные по группе установок на уровне предприятия, но и экологические характеристики используемых технологий. Сбор соответствующей информации осуществляется техническими рабочими группами методом анкетирования по составленному в определенном формате единому шаблону. Анкета предусматривает ответы с достаточной степенью детализации на вопросы, касающиеся используемых технологий (включая способ проектирования, строительства, обслуживания, эксплуатации и вывода из эксплуатации установок), а также потребления установками ресурсов и наблюдаемых (измеряемых) эмиссий, в частности: расхода сырья и вспомогательных материалов, включая вторичное сырье и материалы; использования воды (технологической и охлаждающей) и ее источников; использования энергии (типа и количества топлива, его расхода с разграничением между тепловой и электрической энергией, производства и продаж энергии, потерь тепла); количества сбрасываемых технологических сточных вод, их источников, уровней сбросов в воду загрязняющих веществ в виде концентраций и/или удельных значений по каждому рассматриваемому потоку сточных вод, наличия станций очистки воды; уровней выбросов в атмосферу загрязняющих веществ в виде концентраций и/или удельных значений с указанием источников, расхода дымовых газов.

Информация по текущему уровню эмиссий и потребления служит основой для оценки основных межсредовых эффектов (cross-media effects) и взаимозависимостей, отражающих диффузию загрязняющих веществ из одной природной среды в другую в ходе производственного процесса. Данные по эмиссиям и потреблению подаются с указанием рабочих условий, при которых они были получены (процент используемой проектной мощности установки, наличие несоответствий нормальным условиям производства и т. п.). Для повышения объективности анализа и удобства представления информации (средних значений, максимумов, минимумов, диапазонов) могут использоваться статистические методы обработки данных [189, (2.3.6)].

Представленная информация по отходам должна включать: 1) типы и количество образованных отходов в результате деятельности установки / завода; 2) физические / химические характеристики образованных отходов (например, содержание металлов, среднее содержание сухого твердого вещества); 3) удельный вес утилизируемых и перерабатываемых/повторно используемых отходов; 4) информацию об используемой технологии (включая способ проектирования, строительства, обслуживания, эксплуатации и вывода из эксплуатации установок) для предотвращения либо уменьшения образования отходов.

Представленные экологические характеристики и эксплуатационные данные должны сопровождаться необходимой для анализа общей информацией об установке, производственных процессах, технологическом оборудовании, условиях 
функционирования оборудования, типах производимых продуктов и о том, как их качество и состав могут влиять на потребление ресурсов и уровень эмиссий. Кроме того, указываются меры, принимаемые для предотвращения либо снижения загрязнения при нарушениях нормальных условий эксплуатации установки, и меры по снижению вероятности воздействия на ОС аварий / инцидентов.

B BREF, помимо прочего, описываются надлежащая практика эксплуатации установок с НДТ, профилактические системы технического обслуживания, методы управления производственным процессом и меры в случае возникновения непредвиденных обстоятельств.

Экономический фактор при выборе НДТ, как отдельный аспект информационного наполнения BREF, отражен в документе 2012/119/EU следующим образом. Описание НДТ должно включать данные по затратам на внедрение и использование НДТ (инвестируемый капитал, издержки эксплуатации и технического обслуживания), а также сведения о том, как приведенные затраты рассчитывались. Предоставляется информация о любом виде экономии ресурсов в случае применения НДТ (экономия от снижения потребления сырья или энергии, уменьшения сборов за отходы, сокращения времени окупаемости по сравнению с другими технологиями). Приводятся данные о возможных доходах от внедрения НДТ и способах их оценки. Если имеется информация по отраслевому рынку, она тоже приводится. В качестве «движущей силы» внедрения НДТ в BREFs могут отражаться экономические стимулы, такие как субсидии, налоговые льготы [189, (2.3.2.7)].

В рамках процедуры разработки BREF эффективность затрат, по мнению ряда экспертов, не является самостоятельным критерием, однако выступает в качестве составной части критерия экономической целесообразности, который предполагает сопоставление финансовых затрат и достигаемых при внедрении технологии экологических преимуществ [118]. В процессе определения НДТ экономическая оценка технологии (технического решения) дается технической рабочей группой с позиций целесообразности инвестирования в эту технологию (техническое решение). Технология считается экономически приемлемой, если есть однозначное свидетельство результатов ее промышленной эксплуатации, что открывает возможности для широкого внедрения выбранной технологии в соответствующем секторе промышленности с учетом общих финансовых затрат и экологических преимуществ.

При этом доступность технологии для операторов означает, прежде всего, отсутствие патентной защиты, ограничивающей ее применение. В рамках Севильского процесса не определен теоретический подход к оценке экономической целесообразности, однако в странах ЕС технология считается экономически приемлемой, если она применяется на 100-200 объектах без сопутствующих государственных субсидий [162].

\subsection{4. Особенности регулирования обращения с отходами горнодобывающей промышленности в странах Европейского союза}

Как было отмечено выше, в 2006 г. была принята новая Рамочная директива 2006/12/ЕС «Об отходах», статья 2 которой гласила, что из сферы ее действия исключаются отходы, возникающие в результате разведки, добычи, обработки и хранения минеральных ресурсов, а также разработки карьеров [193]. За несколько 
недель до этого, в марте 2006 г., была принята Директива 2006/21/ЕС «Об управлении отходами добывающей промышленности и внесении изменений в Директиву 2004/35/ЕС». Именно этот действующий правовой акт регулирует обращение с отходами разведки, добычи, обработки и хранения минеральных ресурсов, а также разработки карьеров (extractive waste) [192]. Его требования не распространяются на отходы, полученные при морской разведке, добыче и переработке минеральных ресурсов, и на процессы закачки воды в подземные пласты.

Директива 2006/21/ЕС определяет, что государства - члены ЕС обязаны обеспечить, чтобы операторы объектов (установок) для обработки отходов ${ }^{50}$ предпринимали все необходимые меры для предотвращения или, насколько это возможно, снижения любых неблагоприятных воздействий на ОС и здоровье человека, возникающих в результате обращения с отходами добычи. Принимаемые меры должны базироваться на НДТ. Статья 5 требует от операторов, ответственных за обращение с отходами добычи, составлять и пересматривать каждые пять лет план управления отходами (waste management plan) с целью минимизации отходов производства, снижения их отрицательного воздействия на $\mathrm{OC}$, их обработки ${ }^{51}$, рекуперации и утилизации с учетом принципа устойчивого развития. План управления отходами должен содержать информацию, позволяющую компетентному органу оценить способность оператора достигать поставленные цели по снижению количества отходов, их повторному использованию, обезвреживанию, переработке, безопасному краткосрочному и долгосрочному хранению. Компетентный орган утверждает план управления отходами и контролирует его выполнение.

Статья 7 Директивы 2006/21/EC предписывает выдачу компетентным государственным органом разрешений на эксплуатацию объектов по обработке отходов и перечисляет требования к содержанию заявки оператора на получение такого разрешения, одним из которых является предоставление оператором компетентному органу финансовой гарантии для реабилитации загрязненной территории, если в этом возникнет потребность, вследствие нарушений на объекте для обработки отходов. Условия выдаваемого разрешения должны при необходимости обновляться, в том числе в случае существенных изменений в НДТ. Информацию по обновлению НДТ должен отслеживать компетентный орган.

Государствам - членам ЕС предписано обеспечивать своевременное доведение до общественности информации о поступивших заявках на выдачу разрешения эксплуатации объектов для обработки (размещения) отходов, а также обеспечивать участие представителей общественности в процедуре выдачи разрешений с правом высказывать замечания и мнения по заявке. Результаты консультаций компетентного органа с общественностью должны быть учтены при принятии решения по заявке с предоставлением заинтересованным лицам копии выдаваемого оператору разрешения.

50 Под объектом для обработки отходов (waste facility) в Директиве 2006/21/ЕС понимается любая зона ( $\mathrm{area}$ ), предназначенная для накопления или размещения отходов добычи в твердом или жидком состоянии, в растворе или суспензии в течение определенного времени в зависимости от категории отходов.

${ }^{51}$ Под обработкой (treatment) в Директиве 2006/21/EC понимается процесс «извлечения минерального сырья из минеральных ресурсов» (добыча и обогащение полезных ископаемых), включая повторную обработку получаемых отходов. 
Компетентные органы должны удостовериться, что операторы установок (объектов) для обработки (размещения) отходов приняли все необходимые меры для предотвращения ухудшения состояния грунтовых вод, воздуха и почвы. Сами применяемые для обработки отходов установки (объекты) могут относиться к одной из двух категорий в зависимости от степени возможных рисков: категория А - установки для обработки отходов, нарушение эксплуатации или повреждение которых могут стать причиной крупной аварии или катастрофы; категория В - прочие установки.

В процессе эксплуатации объектов и после ее завершения компетентные органы регулярно инспектируют установки (объекты) с целью проверки соответствия условиям разрешения, а операторы обеспечивают доступность инспектирования любых объектов для обработки отходов. Операторы (предприятия) ведут на объекте учет всех операций по обращению с отходами и предоставляют данные инспектирующим лицам. За нарушения норм и положений Директивы 2006/21/EC государства — члены EC в рамках национального законодательства устанавливают штрафы, которые должны быть эффективными, пропорциональными и сдерживающими.

Таким образом, с 2006 г. в странах ЕС регулирование обращения с отходами добывающих отраслей промышленности законодательно выведено изпод действия Рамочной директивы об отходах 2008/98/EC, однако, что весьма важно, лишь в той части, которая охватывается Директивой 2006/21/ЕС. В целом же, как указано в Директиве 2006/21/EC, управление отходами добывающих отраслей промышленности должно отражать принципы и приоритеты, определенные Рамочной директивой 2008/98/ЕС об отходах в соответствии с концепцией устойчивого развития. Положения рамочной директивы продолжают применяться к любым аспектам обращения с отходами добывающих отраслей, на которые не распространяется Директива 2006/21/EC, в частности на потоки отходов, которые, хотя и образуются в ходе операций по добыче или переработке полезных ископаемых, но напрямую не связаны с процессом получения минерального сырья, например, отработавшие аккумуляторы или технические масла. То есть при обращении с отходами, образующимися в результате извлечения, обработки и хранения минеральных ресурсов, а также разработки карьеров, должны приниматься предусмотренные Директивой 2010/75/EC о промышленных эмиссиях и Решением ЕК 2012/119/EU необходимые меры по борьбе с загрязнениями ОС на основе НДТ. Специфической для отходов горнодобывающей промышленности системной мерой является составление плана управления отходами. План должен быть ориентирован на [124]: предотвращение и сокращение образования отходов, их НВОС; стимулирование утилизации отходов посредством их использования в качестве вторичных материальных ресурсов, повторного использования; стимулирование безопасного краткосрочного и долгосрочного размещения отходов. План управления отходами должен включать: описание отходов и их классификацию; описание реагентов, используемых для обработки минеральных ресурсов; методы размещения и системы, используемые для транспортирования отходов; описание операций, в результате которых образуются эти отходы; процедуры контроля и мониторинга; классификацию установок для обработки отходов (где уместно); план закрытия (вывода из эксплуатации) объектов хозяйственной деятельности и процедуры, осуществляемые после их закрытия (вывода из эксплуатации); меры по 
предотвращению загрязнения водных объектов и почвы; инспектирование состояния территорий, на которые воздействовали объекты обработки отходов.

Выдающие разрешения на эксплуатацию установок (объектов для обработки отходов) государственные компетентные органы при их инспектировании, в том числе после их вывода из эксплуатации, должны убедиться, что операторы (хозяйствующие субъекты) осуществляют меры для предотвращения загрязнений водных объектов и почвы, в частности: проводят оценку выщелачивания почв и образования загрязнений при фильтрации воды через почву; обеспечивают предотвращение образования сточных вод и загрязнений, растворяющихся при фильтрации воды через почву, и предотвращение загрязнения отходами поверхностных или грунтовых вод; проводят обработку загрязненных стоков и сточных вод, чтобы гарантировать их безопасный сброс.

Операторы (хозяйствующие субъекты) должны предпринимать меры для обеспечения устойчивости и стабильности отходов при их размещении в пустотах, образовавшихся после выемки породы и грунта, с целью реабилитации территории. Проведение мониторинга состояния отходов должно обеспечить предотвращение загрязнения почвы и водных объектов.

Рассмотрение базовых правовых актов Европейского союза в области отходов и защиты ОС от вредных промышленных эмиссий позволяет заключить, что законодательство государств - членов ЕС непрерывно развивается, обновляются стандарты контроля загрязнителей $\mathrm{c}$ целью обеспечения положительной динамики в борьбе за снижение образуемых технологических отходов и создание «чистой» экономики. Частью этого процесса является регулирование обращения с отходами горнодобывающей промышленности на основе концепции и механизма НДТ.

Приведенные выше директивы и другие нормативные документы образуют каркас европейской институциональной среды и механизма защиты экосистем от промышленных загрязнений. Европейская модель была взята за основу модернизации российской системы государственного экологического регулирования. Эта модель поэтапно и адаптированно реализуется в настоящее время.

\section{2. Новая экологическая стратегия и переход на европейскую модель регулирования}

\subsection{1. Направления реформирования системы государственного экологического регулирования и обращения с отходами}

Правительственный проект реформирования системы государственного экологического регулирования официально стартовал в 2014 г. с принятием Федерального закона № 219-Ф3 «О внесении изменений в Федеральный закон “Об охране окружающей среды и другие законодательные акты”». Вступление его в силу с 1 января 2015 г. положило начало практическому внедрению новой для России парадигмы экологического регулирования, основанной на концепции НДТ и выдаче комплексных экологических разрешений.

Законодательному старту реформы, напрямую затрагивающей сферу управления ГПО, предшествовало принятие в 2012 г. Основ государственной политики в области экологического развития Российской Федерации на период до 2030 года, содержащих ряд базовых принципов и механизмов реализации 
государственной экологической политики. Документ определил, что к основным задачам государственной политики в области экологического развития, в частности, относятся: обеспечение экологически ориентированного роста экономики и внедрения экологически эффективных инновационных технологий; предотвращение и снижение текущего НВОС; обеспечение экологически безопасного обращения с отходами.

Были определены основные механизмы решения поставленных задач, среди которых [171]: внедрение инновационных ресурсосберегающих, экологически безопасных и эффективных технологий на базе единой технологической платформы с активным участием государства, бизнессообществ, организаций науки и образования и др.; экологическое нормирование на основе технологических нормативов при условии обеспечения приемлемого риска для ОС и здоровья населения; поэтапное исключение практики установления временных сверхнормативных выбросов и сбросов загрязняющих веществ в ОС; предупреждение и сокращение образования отходов, их вовлечение в повторный хозяйственный оборот посредством максимально полного использования исходного сырья и материалов, предотвращения образования отходов в источнике их образования, сокращения объёмов образования и снижения уровня опасности отходов, использования образовавшихся отходов путём переработки, регенерации, рекуперации, рециклинга; внедрение и применение малоотходных и ресурсосберегающих технологий и оборудования; создание и развитие единой автоматизированной государственной системы экологического мониторинга, оснащённой современной измерительной, аналитической техникой и информационными средствами; внедрение методов учёта негативного воздействия на ОС c использованием инструментальных (автоматизированных) систем; гармонизация законодательства Российской Федерации об охране ОС c международным экологическим правом.

Методологической основой реализации новой государственной экологической политики в области обращения с промышленными отходами, загрязняющими ОС, в том числе отходами горного производства (недропользования), стала применяемая в Европейском союзе модель государственного экологического регулирования промышленных эмиссий, которая предусматривает использование технологических показателей НДТ и экологического нормирования для установления объектам НBOC технологических нормативов выбросов / сбросов загрязняющих веществ посредством выдачи комплексных экологических разрешений. Был заимствован положительный европейский опыт, адаптированный к российским реалиям. Особенности новой концепции, а также проблемные аспекты, связанные с ее переносом в отечественную институциональную среду, достаточно широко обсуждались научным и экспертным сообществами [84-86].

В 2017 г. была принята Стратегия экологической безопасности Российской Федерации на период до 2025 года, которая рассматривает экологическую безопасность РФ как часть национальной безопасности и оценивает экологически неблагополучным состояние ОС на $15 \%$ территории страны, где сосредоточены значительная часть населения и производственных мощностей, наиболее продуктивные сельскохозяйственные угодья. В стратегии обращается внимание на то, что, по экспертным оценкам, экономические 
потери, обусловленные ухудшением качества ОC, даже без учета ущерба здоровью людей, ежегодно составляют 4-6 \% российского ВВП [187, ст. 5, 18].

Стратегия предусмотрела ряд приоритетных направлений решения задач в области обеспечения экологической безопасности. К ним относятся развитие системы эффективного обращения с отходами, создание индустрии утилизации отходов, в том числе повторного применения, а также минимизация ущерба, причиняемого ОС при разведке и добыче полезных ископаемых, внедрение инновационных и экологически чистых технологий.

Основными механизмами реализации государственной политики в сфере обеспечения экологической безопасности, в частности, названы [187, ст. 26, 27]: стимулирование внедрения НДТ, создание современных объектов размещения отходов, увеличение объема их повторного применения за счет субсидирования, предоставления налоговых и тарифных льгот, других форм поддержки; внедрение комплексных экологических разрешений в отношении экологически опасных производств, использующих НДТ.

Проблемной составляющей обращения с отходами является их обезвреживание и использование в качестве вторичного сырья. До недавнего времени в Российской Федерации практически отсутствовала государственная политика, системно охватывающая проблему утилизации образуемых и хранящихся отходов, включая наиболее массовую их категорию - ГПО. Государственное экологическое регулирование на основе НДТ акцентирует внимание, в первую очередь, на экологической безопасности промышленных производств, предотвращении их вредного воздействия на ОС. При этом в тени, на наш взгляд, остается вопрос создания и обновления самих HДT, которые, собственно, и должны обеспечивать высокий уровень защиты от вредных веществ, образующихся в процессе производства товарной продукции.

Решение проблемы снижения образования отходов и их безопасной утилизации, в том числе путем повторного применения, непосредственно связано с разработкой и внедрением инновационных технологий, которые впоследствии получат статус наилучших доступных. При переводе российской системы экологического регулирования на принципы НДТ в качестве наилучших были выбраны наиболее прогрессивные технологические решения из тех, которые применяют крупные отечественные загрязнители ОС. Это допускается самой концепцией НДТ, однако возникает вопрос: чем определять доступность НДТ внутри отрасли? При наличии возможности заимствовать (закупать, привлекать через механизмы портфельного инвестирования либо стратегического участия в бизнесе) наилучшие в экологическом смысле иностранные технологии процесс трансграничной диффузии НДТ может обеспечить приток инновационных решений и в перспективе функционирование механизма последовательных улучшений.

При наличии ограничений для трансграничного перетока наилучших технологий, например из-за экономических санкций, механизм НДТ может заработать лишь в условиях налаженного технологического импортозамещения. Надо учитывать, что стратегическая продуктивность европейской системы борьбы с промышленными загрязнениями на основе НДТ, в том числе в горнодобывающей отрасли, обеспечивается динамическим характером потока инноваций. Источником продуктивности выступает способность системы периодически генерировать технологические улучшения (с ужесточением 
технологических показателей НДТ) и практически внедрять их отраслевыми лидерами, к которым вынуждены «подтягиваться» остальные производители, например, минерального сырья.

Если же ограничения на высокотехнологичный импорт в добывающих отраслях будут сохраняться, а технологическое импортозамещение окажется недостаточным, возникнут предпосылки для консервации экологически недостаточно эффективных производств, чьи технологии на начальном этапе внедрения регулирующего механизма были вынужденно признаны как НДТ. В этом случае начальные условия экологической реформы станут ее конечными результатами, а сама реформа не достигнет поставленных целей.

Даже если российские производители минерального сырья «подтянутся» к уровню компаний, чьи технологии добычи и переработки минеральных ресурсов будут нормативно определены как НДТ (эмиссии в пределах технологических показателей НДТ), то при отсутствии периодических улучшений общий уровень загрязнений в отрасли может выровняться, но положительная динамика не получит развития. Вредные воздействия промышленных установок с НДТ на ОС в лучшем случае не увеличатся, а накопление ГПО и их давление на природные экосистемы продолжатся с нарастающим эффектом. Чтобы этого не произошло, необходимы стимулы, которые обеспечат внедряемому механизму НДТ непрерывную динамику технологических улучшений.

Применительно к горнодобывающей промышленности проблема создания все более эффективных технологий для основных производств и переработки техногенных отходов является весьма специфической и требует отдельного рассмотрения. Однако именно решение данной проблемы является необходимым условием материально-технического обеспечения выполнения требований экологической безопасности растущего сектора добычи полезных ископаемых. Комплексный подход требует, по нашему мнению, чтобы создание и внедрение НДТ в деятельность горнодобывающих предприятий стало предметом государственного регулирования и стимулирования не только в области экологии, но и в области науки, промышленности и недропользования.

Стратегия констатирует, что сложившаяся за десятилетия система обращения с отходами на территории нашей страны нуждается в коренной перестройке, она не отвечает мировым тенденциям в области обеспечения экологической безопасности и рационального использования природных ресурсов как факторам устойчивого развития. Мировой опыт, как отмечается в Стратегии, свидетельствует, что главный эффект в решении проблемы отходов связан с вовлечением отходов, в том числе горнопромышленных, в повторное использование. Устойчивость самой системы обращения с отходами обеспечивается развитием рынка вторичного сырья из утилизированных отходов, недопущением их нелегального захоронения, применением принципа «загрязнитель платит».

В России не сформирован научно-технический и производственный потенциал в сфере обработки, утилизации и обезвреживания отходов, практически не ведутся работы по технологиям применения вторичных ресурсов. НИУ и вузы не способны в достаточной степени обеспечить новую отрасль современными инновационными разработками, позволяющими повысить экологическую безопасность и ресурсосбережение, реализовать эффективное функционирование 
отрасли на основе импортозамещения по основным видам оборудования, техники и технологий [186]. В этой связи перспективным направлением научных исследований и разработок являются исследования, нацеленные на создание технологий использования вторичного сырья из отходов, что отражено в Прогнозе научнотехнического развития Российской Федерации на период до 2030 года. Это относится как к отходам потребления, прежде всего ТКО, так и к отходам производства, включая отходы добычи полезных ископаемых, представленные вскрышными и вмещающими породами и продуктами обогащения минерального сырья, доля которых, согласно статистике, составляет 86-90 \% от общей массы отходов, ежегодно образующихся в России.

В качестве механизма восстановления научно-технического потенциала и развития научно-производственной деятельности в области высокотехнологичной комплексной переработки отходов и эффективного использования вторичных ресурсов рассматривается создание экотехнопарков. Предполагается, что экотехнопарки, как площадки для разработок и внедрения новых технологий, смогут объединить участников процесса обработки, утилизации и обезвреживания специализированных потоков отходов, обеспечить взаимосвязь производственной, научно-исследовательской, а также соответствующей образовательной деятельности.

В Стратегии развития промышленности по обработке, утилизации и обезвреживанию отходов производства и потребления на период до 2030 года указывается на то, что нормирование в области обращения с отходами сводится лишь к констатации образования, движения и размещения опасных отходов на основе проектов нормативов их образования и лимитов на их размещение. Действенных регулятивно-управленческих решений по ресурсосбережению, внедрению НДТ, вовлечению отходов в хозяйственный оборот, как правило, не принимается. Подавляющая часть отходов IV-V класса опасности направляется в соответствии с утвержденными лимитами их размещения на захоронение. Одной из основных причин этого является экономический фактор, связанный с низкими затратами на захоронение.

Существенной причиной неудовлетворительного положения дел с переработкой отходов и вовлечением их в хозяйственный оборот остается недостаточно эффективная государственная политика в сфере обращения с ними. Общим сдерживающим фактором является несовершенство нормативной правовой базы, например отсутствие требований к обязательной обработке отходов перед их утилизацией. Низкая эффективность государственного контроля и надзора в сфере обращения с отходами способствует их несанкционированному размещению, захоронению с нарушением законодательства, превышению лимитов захоронения. Вовлечению в хозяйственный оборот отходов горнодобывающих и связанных с ними производств препятствуют имеющиеся противоречия между правовыми аспектами государственного экологического регулирования и государственного управления использованием отходов данного вида.

В Стратегии отмечается парадоксальная ситуация, когда, с одной стороны, подавляющая масса отходов исключена из вторичного хозяйственного оборота как предмет товарно-денежных отношений, а с другой стороны, имеется значительное количество незадействованных производственных резервов предприятий промышленности - действующих или потенциальных 
переработчиков отходов, а также запатентованных наилучших доступных отечественных технологий обработки, утилизации и обезвреживания отходов.

В целом Стратегия предполагает курс на возврат в производство вторичных ресурсов, уменьшение количества образующихся отходов и создание комплексной системы экологически безопасного обращения с ними, включая обязательную обработку, утилизацию и обезвреживание. Этот стратегический курс предполагает наращивание использования ценных вторичных (техногенных) минерально-сырьевых ресурсов, что обусловлено старением производственных мощностей в добывающих отраслях, исчерпанием используемых месторождений, ростом затрат на разведку новых запасов полезных ископаемых, а также переполнением, закрытием и консервацией объектов размещения отходов.

Реализация Стратегии позволит направить вектор усилий государства и бизнеса на рационализацию управления обращения с отходами и снижение рисков утраты ключевых технологических компетенций в области ресурсосбережения и переработки отходов, в том числе отходов недропользования. Ожидается, что стимулирующая государственная политика позволит привлечь в новую отрасль необходимые инвестиции и поэтапно реализовать замещение поставляемых по импорту техники, машин и оборудования для обработки, утилизации и обезвреживания отходов на отечественные аналоги.

Важнейшими результатами реализации Стратегии станут [186]: создание и развитие отходоперерабатывающей отрасли, обеспечивающей максимальное вовлечение отходов в хозяйственный оборот для производства востребованной рынком продукции; изменение системы обращения с отходами в пользу утилизации и обезвреживания вместо захоронения, формирование комплексной системы управления и регулирования в области обработки, утилизации и обезвреживания отходов; создание отечественной производственной базы, выпускающей конкурентоспособное оборудование и технологические линии для предприятий, которые используют промышленные объекты с НДТ обработки, утилизации и обезвреживания отходов. К предприятиям, эксплуатирующим основные виды промышленных объектов, образующих отходы и использующих в производстве отработанное вторичное сырье, отнесены в том числе ${ }^{52}$ : предприятия по добыче, извлечению и обогащению металлических руд и угля, добыче нерудных полезных ископаемых; предприятия черной и цветной металлургии; предприятия химической промышленности всех видов; тепловые электростанции и другие объекты, эксплуатирующие промышленные установки для сжигания топлива.

Таким образом, одним из наиболее сложных и ресурсоемких аспектов реализации новой системы государственного экологического регулирования, в основе которого лежит экологическое нормирование и концепция НДТ, является решение проблемы создания и практического внедрения инновационных технологий, которые способны уменьшить образование отходов, оказывающих НBОC, обеспечить безопасное хранение и переработку отходов как вторичного сырья.

\footnotetext{
52 Приложение № 1 к Стратегии развития промышленности по обработке, утилизации и обезвреживанию отходов производства и потребления на период до 2030 года.
} 
В 2018 г. был утвержден паспорт национального проекта «Экология», включающего одиннадцать федеральных проектов с шестилетним сроком реализации (1 октября 2018 г. - 31 декабря 2024 г.). Один из федеральных проектов называется «Внедрение наилучших доступных технологий». Он реализуется под эгидой Минпромторга России, а национальный проект «Экология» в целом под эгидой Минприроды России ${ }^{53}$.

Задачей федерального проекта «Внедрение наилучших доступных технологий», как указано в его паспорте, является применение всеми объектами, оказывающими значительное НВОС, системы экологического регулирования, основанной на использовании НДТ. Для реализации проекта предусмотрено финансовое обеспечение в объеме 2427300,0 млн руб., из них $-1,12 \%$ из федерального бюджета, а 98,88 \% - из внебюджетных источников ${ }^{54}$.

Эксперты экологического форума «Национальный проект «Экология»: задачи бизнеса и государства», состоявшегося весной 2019 г., пришли к выводу, что внедрение НДТ на российских предприятиях является ключевой составляющей национального проекта «Экология». В частности, было подчеркнуто двойное назначение НДТ в России: как инвестиции в создание новых направлений производства оборудования, позволяющего минимизировать вред ОС, и как возможность для развития импортозамещающих технологий в условиях санкционного давления [44].

Одной из мер по реализации поставленных стратегических задач является максимальное использование российского и международного опыта управления отходами и вторичными ресурсами, а также европейского опыта законодательной поддержки концепции комплексного предупреждения и контроля загрязнений на основе НДТ.

\subsection{2. Новации экологического регулирования и этапы перехода на механизм наилучших доступных технологий}

Идея внедрения НДТ в России с целью реформирования системы экологического регулирования стала активно обсуждаться с середины 2000-х гг. Задачи по реформированию были сформулированы в решениях Совета безопасности от 30 января 2008 г. и в Указе Президента РФ от 4 июня 2008 г. № 889. Необходимость реформирования была вызвана несколькими причинами: систематическим увеличением уровня НBOC со стороны предприятий, работающих на экологически неэффективном оборудовании; глобальной экологизацией международных отношений, несоответствием системы российского природоохранного законодательства международным принципам и тенденциям; избыточностью и неэффективностью применяемых на практике

\footnotetext{
${ }^{53}$ Паспорт национального проекта «Экология»: утв. Президиумом Совета при Президенте РФ по стратегическому развитию и национальным проектам (протокол от 24 декабря 2018 г. № 16) // КонсультантПлюс: сайт. URL: http://www.consultant.ru/document/cons_doc LAW_316096/ (дата обращения: 21.09.2019).

${ }^{54}$ Паспорт Национального проекта «Экология». 4.11. Федеральный проект «Внедрение наилучших доступных технологий». С. 37. 5. Финансовое обеспечение реализации национального проекта. С. 45 // КонсультантПлюс: сайт. URL: http://www.consultant.ru/ document/cons_doc_LAW_316096/ (дата обращения: 21.09.2019).
} 
показателей ПДК загрязняющих веществ, прежде всего, из-за отсутствия средств контроля и мониторинга большинства из них.

Отечественные недропользователи, особенно те, чья продукция шла на экспорт, инициировали применение технологических нормативов на основе НДТ. Так, например, еще до 2010 г. объединенная компания «РУСАЛ» направляла в Минприроды России проект комплекса мер по изменению действующего законодательства и принятию новых нормативно-правовых актов с целью реализации концепции перехода предприятий на использование НДТ [110].

В апреле 2014 г. правительство РФ утвердило комплекс мер, направленных на отказ от использования устаревших и неэффективных технологий и переход на принципы НДТ [184]. Комплекс мер предусматривал: анализ международного опыта стимулирования перехода на принципы НДТ и внедрения современных технологий и разработку предложений о возможных сценариях их внедрения; формирование и утверждение порядка разработки информационно-технических справочников и реестров НДТ; разработку нормативной правовой базы, обеспечивающей совершенствование нормирования в области охраны ОС и переход промышленности на принципы НДТ; утверждение концепции реализации перехода на принципы НДТ и внедрения современных технологий в промышленном секторе Российской Федерации; разработку предложений о мерах государственного софинансирования при переходе промышленности на принципы НДТ; разработку предложений о локализации производства импортного оборудования, соответствующего принципам НДТ; разработку информационно-технических справочников и реестров НДТ; разработку и реализацию комплекса мер по стимулированию производства в стране современного технического оборудования, соответствующего принципам НДТ; обеспечение реализации пилотных проектов внедрения НДТ в субъектах Российской Федерации, а также другие меры.

В октябре 2014 г. глава Минпромторга РФ представил председателю правительства РФ план внедрения НДТ в промышленности как инструмент промышленной политики, позволяющий поднять производительность труда, повысить эффективность производства на предприятиях одновременно с внедрением зеленых технологий. Ставилась задача в правоприменительных актах найти компромисс между «закручиванием гаек» в части экологических требований и реальными возможностями бизнеса переходить на чистые технологии ${ }^{55}$. К этому времени был принят Федеральный закон от 21 июля 2014 г. № 219-Ф3 «О внесении изменений в Федеральный закон «Об охране окружающей среды» и отдельные законодательные акты Российской Федерации», который и дал старт правительственной реформе системы экологического регулирования на законодательном уровне.

Согласно статье 1 федерального закона «наилучшая доступная технология - технология производства продукции (товаров), выполнения работ, оказания услуг, определяемая на основе современных достижений науки и техники и наилучшего сочетания критериев достижения целей охраны окружающей среды при условии наличия технической возможности ее

55 Денис Мантуров представил Председателю правительства план внедрения принципов НДТ в промышленности // ГАРАНТ.PУ: сайт. URL: http:/www.garant.ru/products/ipo/prime/doc/70519522/\#review\#ixzz3KLQV8o2G (дата обращения: 21. 09.2019). 
применения». Упомянутое выше сочетание критериев содержится в пункте 4 статьи 28.1: наименьший уровень НВОС в расчете на единицу времени или объем производимой продукции (товара), выполняемой работы, оказываемой услуги; экономическая эффективность ее внедрения и эксплуатации; применение ресурсо- и энергосберегающих методов; период ее внедрения; промышленное внедрение технологии на двух и более объектах, оказывающих НВОС.

В этих критериях нашли отражение принципы, установленные Директивой EC 2010/75/EU о промышленных эмиссиях [196], на что обращают внимание Д. О. Скобелев, Т. В. Гусева, О.Ю. Чечеватова и другие эксперты [118]. В то же время из определения, которое предназначено для идентификации технологий в качестве НДТ [175], не вполне ясно, как конкретно следует применять указанные критерии в тех или иных случаях. Но по своей сути определение соответствует европейскому пониманию НДТ.

Основные новации, «запущенные» федеральным законом № 219-Ф3 [167] в экологическом регулировании на основе механизма НДТ: 1) введено технологическое нормирование НВОС и применение утверждаемых приказами Минприроды России технологических показателей НДТ; 2) введен дифференцированный подход к нормированию воздействия на ОС по категориям ОНВ и ограничен перечень нормируемых загрязняющих веществ (маркерных веществ); 3) введена система государственного учета ОНВ, которые становятся новой учетной единицей НВОС вместо предприятия; 4) введено разделение ОНВ на четыре категории; 5) введены справочники НДТ, создана система разработки справочников НДТ; 6) введено КЭР на эксплуатацию ОНВ и декларация об объемах негативного воздействия; 7) изменена система платы за НВОС, введены коэффициенты, стимулирующие внедрение НДТ на объектах со значительным НBОС; 8) введены программы повышения экологической эффективности для предприятий, ОНВ которых не отвечают требованиям технологических показателей НДТ; 9) введен зачет затрат на мероприятия, включенные в программы повышения экологической эффективности и планы природоохранных мероприятий; 10) продекларированы налоговые льготы и меры государственной поддержки внедрения НДТ; 11) уточнены объекты экологического надзора федерального и регионального уровней и закреплены требования к производственному экологическому надзору; 12) возрожден институт государственной экологической экспертизы. Вышеперечисленные инструменты экологического регулирования вводились поэтапно, по мере разработки и утверждения соответствующих нормативных документов.

Можно выделить три этапа перехода на новую систему государственного экологического регулирования. Первый этап - подготовительный (20142018 гг.). Создана организационно-правовая база применения механизма НДТ, принято большое количество нормативных правовых актов по основным направлениям реформы. В 2015 г. было утверждено одиннадцать национальных стандартов серии ГОСТ Р 56828.X-2015 в области НДТ, которые заложили методологическую основу для разработки в 2015-2017 гг. справочников по НДТ и их применению. Были сформированы структуры, обеспечивающие методическое сопровождение перехода на НДТ: Бюро НДТ, межведомственный совет по переходу на НДТ и внедрению современных технологий; технический комитет по стандартизации «Наилучшие доступные технологии»; технические рабочие группы по разработке справочников НДТ. Технические рабочие группы 
методом анкетирования собрали и систематизировали данные об используемых крупными российскими предприятиями технологиях, относящихся к областям применения НДТ, идентифицировали отраслевые НДТ. На основе полученных данных в подготовительный период разработан и утвержден пятьдесят один информационно-технический справочник НДТ (ИТС по НДТ).

Второй этап — промежуточный (2019-2022 гг). С начала 2019 г. вступил в силу в полном объеме предусмотренный Федеральным законом № 219-Ф3 [167] пакет поправок в закон об охране окружающей среды, установивший новые правила экологического нормирования деятельности организаций. Начался тестовый режим применения системы экологического регулирования на основе НДТ в отношении трехсот выбранных правительством РФ предприятий (объектов НВОС, вклад которых в суммарные выбросы, сбросы загрязняющих веществ в Российской Федерации составляет не менее $60 \%$ ) [182]. К ним относятся предприятия: по добыче и обогащению угля (26), руд цветных металлов (9), железа (7); добыче сырой нефти и природного газа (72); металлургии (23); производству удобрений (5); переработке нефти (15); производству продукции неорганической химии (7); производству электрической энергии (40); производству целлюлозы, бумаги и картона (10); сбору и очистке коммунальных стоков (73); другие (13).

С 2019 по 2022 гг. указанные выше триста объектов НВОС должны получить комплексные экологические разрешения. В этот же период возможна доработка системы выдачи, мониторинга, контроля и оценки эффективности КЭР. Кроме того, планируется внедрение комплекса технических средств, обеспечивающих автоматические измерения и учет показателей выбросов и/или сбросов загрязняющих веществ, фиксацию и передачу информации о показателях выбросов, сбросов в Государственный реестр объектов НВОС [101].

Третий этап - заключительный (2023-2025 гг.), на котором проверяется эффективность нормативной правовой базы, регламентирующей природоохранную деятельность предприятий, которые имеют в своем составе объекты НВОС. С 1 января 2023 г. при превышении объектом НВОС установленной нормы выбросов / сбросов к нему будет применяться повышенный коэффициент платы за НBOC (максимальный коэффициент 100). До начала 2025 г. все предприятия, эксплуатирующие объекты со значительным негативным воздействием (объекты I категории), обязаны получить КЭР. Таких предприятий зарегистрировано к настоящему времени в государственном реестре объектов НВОС уже более семи тысяч.

Предполагается, что на третьем этапе перевода экологического регулирования на механизм НДТ в рамках национального проекта «Экология» будет создана новая для российской промышленности отрасль - экологического машиностроения Ее потенциал, по оценкам экспертов, составляет примерно 50 млрд долл. [9]. Федеральный проект «Внедрение наилучших доступных технологий» в составе национального проекта «Экология» предусматривает масштабную программу технологического перевооружения. Доля импорта основного технологического оборудования снизится с 50 \% в 2018 г. до 36 \% в 2024 г. ${ }^{56}$.

56 Интервью министра природных ресурсов и экологии Дмитрия Кобылкина от 25.09.2018 // Российская газета: сайт. URL: https://rg.ru/2018/09/25/vnedrenie- 


\subsection{3. Государственное экономическое стимулирование внедрения наилучиих доступных технологий}

Правительство Российской Федерации использует различные механизмы экономической поддержки процесса перехода на новое государственное экологическое регулирование. Эта поддержка предполагает экономическое стимулирование промышленных предприятий к внедрению НДТ. Одним из механизмов государственной поддержки общего характера является субсидирование НИОКР по приоритетным направлениям гражданской промышленности при реализации комплексных инвестиционных проектов. Возможность использования этого механизма заложена Постановлением Правительства РФ от 30 декабря 2013 г. № 1312 (в редакции от 21 июля 2017 г.) [173].

Постановление определило Правила предоставления субсидий на компенсацию части затрат на проведение НИОКР по приоритетным направлениям, которые устанавливают цель и условия предоставления таких субсидий из федерального бюджета российским организациям в рамках реализации комплексных инвестиционных проектов. Субсидии предоставляются на конкурсной основе под реализацию комплексных инвестиционных проектов, общая стоимость которых составляет от 100 млн до 2 млрд руб. при условии, что размер кредитных средств, привлекаемых организацией на реализацию инвестпроекта, не более 80 \% его общей стоимости. При этом субсидируется в среднем 50-70 \% по различным видам затрат при осуществлении НИОКР.

Ключевое условие участия в конкурсе на получение субсидии соответствие инвестпроекта одному из приоритетных направлений гражданской промышленности. К ним относятся направления госпрограммы РФ «Развитие промышленности и повышение еe конкурентоспособности», осуществление деятельности по которым способствует, в частности ${ }^{57}$ : созданию новых экономически эффективных и экологически безопасных производств; повышению энергоэффективности и ресурсосбережения; созданию перспективных производственных технологий и др. Одной из задач госпрограммы является содействие внедрению промышленными предприятиями НДТ, а ожидаемым результатом - технологическое обновление промышленности и внедрение НДТ для значительного снижения энергоемкости наиболее энергоемких производств и выпуска современной экологичной продукции.

Другим механизмом государственной поддержки общего характера является субсидирование проиентной ставки по кредитам в соответствии с Постановлением Правительства от 3 января 2014 г. № 3 (в редакции от 1 августа 2019 г.). Субсидии предоставляются в целях снижения затрат на обслуживание долговых обязательств, связанных с реализацией инвестиционных проектов, которые выполняются в рамках госпрограммы «Развитие промышленности и повышение ее конкурентоспособности», и являются источником возмещения

nailuchshih-dostupnyh-tehnologij-obojdetsia-promyshlennikam-v-24-trilliona-rublej.html (дата обращения: 10.10.2019).

57 Государственная программа «Развитие промышленности и повышение еe конкурентоспособности» на 2013-2024 гг. // Минпромторг России: сайт. URL: http://minpromtorg.gov.ru/activities/state_programs/list/gp2 (дата обращения: 10.10.2019). 
части фактически понесенных затрат организации при уплате процентов по кредитам, полученным в 2017-2019 гг., а также уплате купонного дохода по облигациям, эмитированным для целей реализации комплексных инвестиционных проектов.

Еще одним государственным механизмом экономического стимулирования является поддержка инвестиционных проектов на основе проектного финансирования. Постановление Правительства РФ от 11 октября 2014 г. № 1044 (в редакции от 30 декабря 2018 г.) [174] утвердило программу поддержки инвестиционных проектов на основе проектного финансирования, которая установила критерии и порядок отбора инвестиционных проектов и кредитных организаций, а также порядок предоставления государственных гарантий по целевым кредитам, выданным для реализации инвестиционных проектов. Поддерживаемый государством инвестпроект может реализовываться в сфере добычи полезных ископаемых, его полная стоимость должна составлять от 1 до 20 млрд руб., финансирование за счет заемных средств - не более $80 \%$ полной стоимости проекта.

Минпромторг России сообщил, что в рамках реализации федерального проекта «Внедрение наилучших доступных технологий» предусматривается обеспечение ускоренного роста инвестиций в основной капитал за счет масштабной программы технологического перевооружения. Также будет запущен механизм «зеленых облигаций» как отдельный новый инструмент стимулирования инвестпроектов по НДТ. Для поддержки зеленых инвестпроектов изначально создавался Фонд развития промышленности. Минпромторг России разрабатывает правила предоставления субсидий предприятиям на возмещение части затрат и выплату купонного дохода по облигациям, выпущенным после 1 января 2019 г. на срок не менее трех лет в рамках реализации инвестпроектов по внедрению НДТ стоимостью до 15 млрд руб. [9].

Статья 17 Федерального закона «Об охране окружающей среды» предусматривает широкий спектр мер государственной поддержки деятельности, осуществляемой в целях охраны ОС. К ним относится предоставление налоговых льгот, льгот в отношении платы за НВОС, выделение средств федерального бюджета и бюджетов субъектов РФ. Государственная поддержка оказывается проектам по внедрению НДТ, проектированию и строительству систем оборотного и бессточного водоснабжения, сооружений и установок по улавливанию и утилизации выбрасываемых загрязняющих веществ, установке оборудования по использованию, транспортированию, обезвреживанию отходов производства и др.

В связи с принятием концепции НДТ и категорированием промышленных объектов НВОС была изменена система платы предприятий за НВОС. Федеральный закон № 219-Ф3 [167] внес изменения в Федеральный закон № 7-Ф3 «Об охране окружающей среды», которые определили, что плата за НВОС взимается по его видам: за выбросы загрязняющих веществ в атмосферный воздух, сбросы их в водные объекты и размещение (хранение, захоронение) отходов производства и потребления. Ставки платы за НВОС на каждый год устанавливаются правительством РФ [178] применительно к конкретным перечням загрязняющих веществ и отходам по классам опасности.

Плата за НВОС исчисляется лицами, которые обязаны ее вносить, самостоятельно путем умножения величины платежной базы по каждому 
загрязняющему веществу, по классу опасности отходов на соответствующие ставки с применением коэффициентов и суммирования полученных величин. Платежной базой является объем или масса (далее - объем / масса) выбросов, сбросов загрязняющих веществ, либо объем/масса размещенных в отчетном периоде отходов. В целях стимулирования бизнеса к снижению НВОС и внедрению НДТ к ставкам платы за НВОС введено применение понижающих и повышающих коэффициентов (табл. 3.1).

Таблийа 3.1

Коэффициенты, применяемые к ставкам платы за НВОС

\begin{tabular}{|c|l|l|}
\hline \multirow{2}{*}{$\begin{array}{c}\text { Коэффициент } \\
\text { К }\end{array}$} & \multicolumn{1}{|c|}{ Объем или масса на объекте НВОС } \\
\cline { 2 - 3 } & \multicolumn{1}{|c|}{$\begin{array}{c}\text { выбросы, сбросы } \\
\text { загрязняющих веществ }\end{array}$} & \multicolumn{1}{c|}{$\begin{array}{c}\text { отхды производства и } \\
\text { потребления }\end{array}$} \\
\hline 0 & $\begin{array}{l}\text { В пределах технологических } \\
\text { нормативов после внедрения } \\
\text { Ндт }\end{array}$ & $\begin{array}{l}\text { Подлежащие накоплению и } \\
\text { использованные или переданные } \\
\text { для использования в течение } \\
\text { одиннадцати месяцев с момента } \\
\text { их образования }\end{array}$ \\
\hline 1 & $\begin{array}{l}\text { В пределах нормативов } \\
\text { допустимых выбросов, } \\
\text { сбросов }\end{array}$ & $\begin{array}{l}\text { Размещение в пределах лимитов } \\
\text { на размещение }\end{array}$ \\
\hline 25 & $\begin{array}{l}\text { В пределах временно } \\
\text { разрешенных }\end{array}$ & $\begin{array}{l}\text { Размещение с превышением } \\
\text { установленных лимитов на } \\
\text { размещение либо указанных в } \\
\text { декларации для объектов II } \\
\text { категории }\end{array}$ \\
\hline 100 & $\begin{array}{l}\text { Превышающие } \\
\text { установленные для объектов } \\
\text { І категории, а также } \\
\text { превышающие указанные в } \\
\text { декларации для объектов II } \\
\text { категории }\end{array}$ \\
\hline
\end{tabular}

Из суммы платы за НВОС вычитаются затраты на реализацию мероприятий по снижению $\mathrm{HBOC}$, фактически произведенные в пределах исчисленной платы за НBOC. Дифференцированная плата за НBOC и применение иных мер формируют гибкий механизм экономического стимулирования внедрения НДТ, реальная эффективность которого будет определяться особенностями его практического применения (табл. 3.2).

С целью стимулирования мероприятий по снижению НВОС при размещении отходов введены коэффициенты к ставкам платы за НВОС по классам опасности размещенных отходов производства и потребления. Так, например, коэффициент 0 применяется при размещении отходов добывающей промышленности V класса опасности посредством закладки искусственно созданных полостей в горных породах при рекультивации земель и почвенного покрова (в соответствии с разделом проектной документации «Перечень мероприятий по охране окружающей среды» 
и/или техническим проектом разработки месторождения полезных ископаемых). Коэффициент 0,5 применяется при размещении отходов IV, V классов опасности, которые образовались при утилизации ранее размещенных отходов перерабатывающей и добывающей промышленности. При размещении отходов на OРО, исключающих $\mathrm{HBOC}$, плата за размещение отходов производства и потребления не взимается.

Таблица 3.2

Механизм экономического стимулирования внедрения НДТ

\begin{tabular}{|l|l|}
\hline \multicolumn{1}{|c|}{ Льготы } & \multicolumn{1}{|c|}{ Санкции } \\
\hline В процессе внедрения НДТ: & При нарушении сроков внедрения НДТ: \\
зачет платы за НВОС в счет & пересчет платы за НВОС с применением \\
инвестиций & повышенных коэффициенов и ее взыскание \\
\hline После внедрения НДТ: & При отказе от внедрения НДТ: \\
зачет платы за НВОС в счет & рост платы за НВОС до размеров, \\
инвестиций; & сопоставимых с затратами на очистку \\
отказ от взимания платы за & выбросов, сбросов. \\
НВОС после внедрения НДТ & Увеличение коэффициентов платы: \\
(К=0); & за временно разрешенное воздействие \\
ускоренная амортизация & К=25 (К =5 до 31 декабря 2019 г.); \\
оборудования НДТ (К $=2) ;$ & за воздействие, превышающее разрешенное \\
возмещение процентной ставки & К=100 (К =25 до 31 декабря 2019 г.) \\
по кредиту в счет налога на & \\
прибыль (инвестиционный & \\
налоговый кредит) & \\
\hline
\end{tabular}

\section{3. Технологическое нормирование в механизме наилучших доступных технологий}

\subsection{1. Категорирование и государственный учет объектов негативного воздействия на окружсаюую среду}

Одними из первых регулирующих мер на первом этапе перехода к экологическому регулированию на основе механизма НДТ стало определение областей применения НДТ и категорирование объектов НВОС. Распоряжением Правительства РФ от 24 декабря 2014 г. № 2674-р (с изменениями на 24 мая 2018 г.) был утвержден перечень областей применения НДТ, к которым отнесены: 1) хозяйственная и/или иная деятельность, оказывающая значительное НВОС, в том числе: добыча и обогащение железных руд, руд цветных металлов, угля и антрацита; утилизация и обезвреживание отходов; размещение отходов производства и потребления; 2) технологические процессы и оборудование, применяемые в том числе при обращении с вскрышными и вмещающими горными породами.

Были введены четыре категории объектов по степени их воздействия на OC: со значительным воздействием (I категория), с умеренным воздействием (II категория), с незначительным воздействием (III категория), с минимальным 
воздействием (IV категория). Предприятия, имеющие в своем составе или строящие объекты I категории, обязаны получить КЭР на их эксплуатацию.

Постановлением Правительства РФ от 28 сентября 2015 г. № 1029 [177] утверждены критерии отнесения объектов НВОС к каждой из категорий. В частности, критериями отнесения к объектам I категории (для ОНВ, относящихся к областям применения НДТ) является осуществление деятельности: по добыче и обогащению железных руд; добыче и подготовке руд цветных металлов (за некоторым исключением); металлургическому производству (с применением определенного оборудования); обработке и утилизации отходов в части, касающейся обезвреживания отходов производства и потребления с применением оборудования и (или) установок: по обезвреживанию отходов производства и потребления I-III классов опасности, по обезвреживанию отходов производства и потребления IV и V классов опасности (с проектной мощностью три тонны в час и более); по захоронению отходов производства и потребления I-III классов опасности и отходов IV и V классов опасности (20 тыс. т в год и более). В обобщенном виде критерии отнесения объектов НВОС к объектам I-IV категорий показаны в табл. 3.3. После категорирования объектов НВОС были определены соответствующие каждой категории меры государственного регулирования (табл. 3.4).

Таблица 3.3

Общие критерии отнесения объектов НBOC к объектам I-IV категорий

\begin{tabular}{|l|l|}
\hline Категория & \multicolumn{1}{|c|}{ Критерий } \\
\hline I & $\begin{array}{l}\text { Объекты, на которых осуществляется деятельность, относящаяся } \\
\text { к областям применения НДТ, с указанием объемов производства } \\
\text { продукции }\end{array}$ \\
\hline II & $\begin{array}{l}\text { Объекты, относящиеся к областям применения НДТ, с объемом } \\
\text { производства продукции меньше, чем у объектов I категории. } \\
\text { Объекты, на которых осуществляется деятельность, связанная с } \\
\text { обращением радиоактивных веществ. } \\
\text { Порты, аэропорты, трубопроводы и др. }\end{array}$ \\
\hline III & $\begin{array}{l}\text { Исследовательские ядерные установки нулевой мощности, } \\
\text { радиационные источники IV и V категорий. } \\
\text { Объекты, не соответствующие критериям I, II и IV категорий }\end{array}$ \\
\hline $\begin{array}{l}\text { Одновременно: а) масса выбросов не превышает 10 т/год, при } \\
\text { отсутствии веществ I и II классов опасности, радиоактивных } \\
\text { веществ; б) отсутствие сбросов, за исключением бытовых } \\
\text { сточных вод, в системы водоотведения. } \\
\text { Оборудование для получения энергии тепловой мощностью } \\
\text { менее 2 Гкал/час при отсутствии сбросов. } \\
\text { Оборудование исключительно для исследований, разработок и } \\
\text { испытаний }\end{array}$ \\
\hline
\end{tabular}

Примечание. Источник - Венчикова В. Р. НДТ в России. Развитие законодательства и его реализация // Презентация вебинара. 11.07.2019 г. URL: http://webinar.paradigma.center/. 
Таблица 3.4

Меры государственного регулирования объектов НВОС в зависимости от категории объекта

\begin{tabular}{|c|c|c|c|}
\hline \multicolumn{4}{|c|}{ Объект } \\
\hline $\begin{array}{c}\text { со значительным } \\
\text { воздействием } \\
\text { (І категория) }\end{array}$ & $\begin{array}{l}\text { с умеренным } \\
\text { воздействием } \\
\text { (II категория) }\end{array}$ & $\begin{array}{c}\text { с незначительным } \\
\text { воздействием } \\
\text { (III категория) }\end{array}$ & $\begin{array}{c}\text { с минимальным } \\
\text { воздействием } \\
\text { (IV категория) }\end{array}$ \\
\hline $\begin{array}{l}\text { Государственная } \\
\text { экологическая } \\
\text { экспертиза }\end{array}$ & - & - & - \\
\hline \multicolumn{3}{|c|}{ Постановка объектов на государственный учет } & - \\
\hline $\begin{array}{l}\text { Нормирование } \\
\text { на принципах } \\
\text { НДТ }\end{array}$ & $\begin{array}{l}\text { Декларирование } \\
\text { объемов воздействия }\end{array}$ & - & - \\
\hline \multicolumn{3}{|c|}{$\begin{array}{l}\text { Производственный экологический контроль } \\
\text { (дифференциация по категориям объектов) }\end{array}$} & - \\
\hline $\begin{array}{l}\text { Оснащение } \\
\text { источников } \\
\text { приборами } \\
\text { непрерывного } \\
\text { контроля } \\
\end{array}$ & - & - & - \\
\hline \multicolumn{3}{|c|}{ Отчетность об объемах воздействия } & - \\
\hline \multicolumn{3}{|c|}{$\begin{array}{c}\text { Отчетность о выполнении планов мероприятий / программ } \\
\text { внедрения НДТ }\end{array}$} & - \\
\hline $\begin{array}{l}\text { Федеральный } \\
\text { государственный } \\
\text { экологический } \\
\text { надзор }\end{array}$ & $\begin{array}{l}\text { Региональный госуд } \\
\text { экологический надз }\end{array}$ & $\begin{array}{l}\text { арственный } \\
\text { p }\end{array}$ & $\begin{array}{l}\text { Только } \\
\text { внеплановые } \\
\text { проверки }\end{array}$ \\
\hline
\end{tabular}

Примечание. Источник - Венчикова В. Р. НДТ в России. Развитие законодательства и его реализация // Презентация вебинара. 11.07.2019 г. URL: http://webinar.paradigma.center/.

С 1 января 2015 г. по 1 января 2017 г. все лица, осуществляющие хозяйственную и/или иную деятельность, обязаны были поставить принадлежащие им объекты НВОС на государственный учет. Лица, которые только начинают свою деятельность, должны осуществлять постановку на учет в срок не позднее шести месяцев со дня начала эксплуатации объекта НВОС. При осуществлении учета необходимо понимать, что один объект НВОС может включать в себя несколько источников негативного воздействия (в том числе источники выбросов, сбросов, площадки размещения отходов) и должен удовлетворять требованию территориальной связанности.

Для ведения учета была создана специализированная информационная система - Государственный реестр объектов НBOC (оператор - Росприроднадзор). Система предоставляет личные кабинеты природопользователям, сотрудникам Росприроднадзора и органов субъектов РФ, обеспечивает доступ к информации об объемах выбросов, сбросов, отходов зарегистрированных объектов НВОС. 
Техническое функционирование реестра обеспечивают более ста серверов и более 1300 программно-аппаратных комплексов защиты информации.

По данным на 30 апреля 2019 г. поставлено на учет 282796 объектов, из них: 98662 - объекты федерального уровня, 184134 - объекты регионального уровня. Ситуация по категориям объектов представлена в табл. 3.5.

Таблийа 3.5

Постановка на государственный учет объектов НВОС

\begin{tabular}{|c|c|c|}
\hline $\begin{array}{c}\text { Категория объекта } \\
\text { НВОС }\end{array}$ & $\begin{array}{c}\text { Федеральный уровень } \\
\text { надзора }\end{array}$ & $\begin{array}{c}\text { Региональный уровень } \\
\text { надзора }\end{array}$ \\
\hline I & 7358 & - \\
\hline II & 29423 & 8709 \\
\hline III & 53281 & 124490 \\
\hline IV & 8600 & 50935 \\
\hline
\end{tabular}

Примечание. Источник - Венчикова В. Р. НДТ в России. Развитие законодательства и его реализация // Презентация вебинара. 11.07.2019 г. URL: http://webinar.paradigma.center/.

Порядок создания и ведения Государственного реестра объектов НВОС установлен Постановлением Правительства РФ от 23 июня 2016 г. № 572. Критерии объектов федерального государственного экологического надзора определены Постановлением Правительства РФ от 28 августа 2015 г. № 903. Порядок формирования кодов объектов НВОС и их присвоения установлен Приказом Минприроды России от 23 декабря 2015 г. № 553. Форма заявки о постановке на государственный учет объектов НВОС утверждена Приказом Минприроды России от 23 декабря 2015 г. № 554.

\subsection{2. Система технологического нормирования и порядок расчета технологических нормативов}

Ключевой новацией закона № 219-Ф3 является введение нового технологического - нормирования выбросов и сбросов загрязняющих (маркерных) веществ, сущность которого заключается в установлении технологических нормативов на эмиссии вредных веществ стационарными источниками НВОС для объектов I категории.

В рамках старого регулирования хозяйствующий субъект готовил проект ПДВ на основе Методики расчета рассеивания веществ в атмосфере с учетом фонового загрязнения воздуха, определяемого по данным мониторинга, а Росприроднадзор выдавал разрешение на выброс вредных веществ, в котором устанавливались нормативы ПДВ. При превышении ПДВ устанавливались лимиты на выбросы при наличии планов их снижения, сроки реализации которых определяются субъектами РФ. На практике использовались только нормируемые химические показатели - нормативы предельно допустимой концентрации (ПДК) веществ, которые являлись едиными для всей территории РФ и носили безусловный характер, т. е. должны были соблюдаться в любой момент времени независимо от применяемых технологий. 
Новое нормирование определяет, что для объектов I категории нормативы выбросов/сбросов загрязняющих (маркерных) веществ III и IV классов опасности не должны превышать удельные показатели выбросов НДТ, указанные в справочниках НДТ. Нормирование загрязняющих веществ I и II классов опасности осуществляется по-старому. Для объектов II категории вводится представление декларации с расчетом нормативов выбросов в рамках старой системы экологического регулирования.

Система технологического нормирования предполагает идентификацию объектов технологического нормирования (объектов НВОС или отдельных установок в их составе), которые позволяют их владельцу рассчитать технологические нормативы эмиссий загрязняющих веществ в ОС, отталкиваясь от значений технологических показателей идентифицированных объектов и технологических показателей НДТ. Данные расчетов заносятся в заявку на получение КЭР. Под эмиссией в ОС понимают прямой или опосредованный выпуск в воздушную и водную среды, на/под земную поверхность веществ, вибрации, шума, тепла, электромагнитных или прочих излучений (ГОСТ Р 56828.15-2016, пункт 2.218).

В соответствии со статьей 1 Закона «Об охране окружающей среды» технологические нормативы - нормативы выбросов, сбросов загрязняющих веществ, нормативы допустимых физических воздействий, которые устанавливаются с применением технологических показателей. В свою очередь, технологические показатели - показатели концентрации загрязняющих веществ, объема и (или) массы выбросов, сбросов загрязняющих веществ, образования отходов производства и потребления, потребления воды и использования энергетических ресурсов в расчете на единицу времени или единицу производимой продукции (товара), выполняемой работы, оказываемой услуги. В соответствии с ГОСТ Р 56828.15-2016 (пункт 2.174) система нормирования, основанная на технологических нормативах (система технологического нормирования) - это совокупность допустимых нормативов, установленных с учетом требований по достижению минимально возможного воздействия на ОС посредством использования НДТ.

15 апреля 2019 г. вступили в действие Правила разработки технологических нормативов в части выбросов и сбросов загрязняющих веществ, утвержденные Постановлением Правительства РФ от 14 февраля 2019 г. № 89, которыми предусмотрено, что технологические нормативы разрабатываются для объектов НВОС или для их частей (объекты технологического нормирования - ОТН). В качестве объекта нормирования, входящего в объект НВОС, может выступать отдельная установка или оборудование. В целях технологического нормирования принимается, что именно на ОТН реализуются технологические процессы (используется оборудование, применяются технические способы и методы) действующих производств (либо планируется их реализация на создающихся производствах), описанные в ИТС по НДТ в отношении загрязняющих (маркерных) веществ, для которых установлены технологические показатели НДТ. Соответственно, расчет технологических нормативов может осуществляться как по отношению к действующим объектам НBОC/OTH, так и по отношению к объектам НВОС / ОТН, планируемым к вводу в эксплуатацию. 
Необходимо также учитывать, что справочниками по НДТ технологические показатели НДТ по выбросам, сбросам могут быть установлены как в виде удельных значений массы выбросов/ сбросов маркерных загрязняющих веществ, так и в виде их концентраций в выбросах / сбросах. Соответственно, при проведении расчетов технологических нормативов необходимо учитывать вид установленного ТП. Порядок расчета от этого, по сути, не меняется.

Следует отдельно остановиться на маркерных веществах. Определение маркерного вещества дано в ГОСТ Р 56 828.15-2016 (пункт 2.77): маркерное вещество - наиболее значимый для конкретного производства показатель, выбираемый по определенным критериям из группы веществ, внутри которой наблюдается тесная корреляционная взаимосвязь. Особенностью маркерного вещества является то, что с его помощью можно оценить значения всех веществ, входящих в группу. В соответствии с пунктом 7.1.2 Методических рекомендаций по определению технологии в качестве НДТ, утвержденных Приказом Минпромторга России от 31 марта 2015 г. № 665 для выбросов и сбросов загрязняющих веществ, рекомендуется выделять ключевые (маркерные) загрязняющие вещества. В справочниках по НДТ ТП приведены для маркерных веществ. Именно они, согласно статье 67 закона об охране окружающей среды, подлежат измерению в обязательном порядке при осуществлении производственного экологического контроля. Иными словами, маркерные вещества - это основные загрязняющие вещества, поддающиеся количественной оценке, критичные для данной технологии (отрасли).

Правительство РФ утвердило перечень загрязняющих веществ, в отношении которых применяются меры государственного регулирования в области охраны ОС. В него входят 254 наименования для атмосферного воздуха, 249 - для водных объектов и 63 - для почв [185]. При выборе маркерных веществ разработчики справочников НДТ должны были ориентироваться на данный перечень, однако, как указывают эксперты, имеются случаи, когда для ТП используются группы веществ, которые в перечне отсутствуют [96].

Рассчитываемый технологический норматив выбросов или сбросов представляет собой годовую массу выбросов или сбросов и устанавливается для каждого объекта нормирования, оказывающего НВОС. Предполагается, что при наличии утвержденных ТП НДТ в виде показателя концентрации загрязняющего вещества в выбросах / сбросах технологический норматив, наряду с параметром, отражающим объем годового выброса / сброса, может быть установлен в виде величины, выраженной в концентрациях загрязняющих веществ.

А. 3. Ощепкова и В. Р. Венчикова обращают внимание на то, что законом № 219-Ф3 в качестве технологических нормативов рассматриваются нормативы выбросов и сбросов загрязняющих веществ, нормативы допустимых физических воздействий, но «показатели, характеризующие годовое образование отходов, на сегодняшний день не отнесены к технологическим нормативам; в то же время законодательством предусмотрен технологический показатель образования отходов, поэтому вполне логично ввести в состав технологических нормативов там, где это целесообразно и возможно, и этот параметр» [96, с. 12]. Мы разделяем такую точку зрения, поскольку включение технологического норматива образования отходов в КЭР на завершающей стадии технологического нормирования полноценно «запустит» механизм НДТ для регулирования данного параметра. Могут возникнуть 
некоторые сложности в части инструментального экологического контроля размещаемых отходов, поэтому следует направить усилия на решение этой задачи.

Результатом разработки технологических нормативов для объекта НВОС являются расчеты технологических нормативов, которые включаются в заявку на получение КЭР или заявку на пересмотр КЭР. Для каждого ОТН расчет должен содержать [180]: 1) определение ОТН и маркерных веществ на основании анализа технической документации ${ }^{58}$; анализ ОТН с подготовкой перечней выявленных ОТН и маркерных веществ ${ }^{59}$ для каждого ОТН; 2) определение ТП для выбросов/сбросов маркерных веществ ОТН в целях оценки соответствия утвержденным ТП НДТ; 3) определение годовых технологических нормативов для каждого ОТН.

Для действующих ОТН определение ТП выбросов/сбросов и технологических нормативов включает: 1) определение показателей выбросов/ сбросов, маркерных веществ для каждого стационарного источника выбросов в атмосферный воздух и каждого выпуска сточных вод в составе ОТН с использованием технической документации, данных инвентаризации выбросов / сбросов, результатов производственного экологического контроля за несколько лет, но не более пяти; 2) расчет годовых валовых выбросов, годовой массы сбросов каждого маркерного вещества для ОТН как суммы массы выбросов маркерного вещества всех стационарных источников и суммы массы сбросов маркерного вещества всех выпусков сточных вод в составе ОТН либо методом материального баланса ${ }^{60}$ в случае выброса / сброса загрязняющих веществ после их сбора, очистки, сбросов от нескольких ОТН; 3) определение величины годового выпуска продукции как показателя максимального объема произведенной продукции на ОТН в течение года за несколько лет (не более пяти), предшествующих году, в котором производится расчет технологических нормативов; 4) расчеты удельных значений массы выбросов, сбросов каждого маркерного загрязняющего вещества в расчете на единицу производимой продукции путем деления годовых валовых выбросов/ годовой массы сбросов каждого маркерного вещества на величину годового выпуска продукции на ОТН; 5) определение значений ТП для выбросов / сбросов и технологических нормативов для ОТН. Для действующего ОТН значения ТП принимаются равными удельным значениям массы выбросов / сбросов этим ОТН маркерного вещества, если ТП НДТ установлены в виде удельного значения массы выбросов / сбросов маркерных веществ на единицу продукции.

58 Документация, регламентирующая проведение технологических операций, в том числе проектная (конструкторская) документация, технологические регламенты, руководства (инструкции) по эксплуатации, схемы, технические условия и другая эксплуатационная документация для действующих объектов или проектная документация на строительство, реконструкцию объекта капитального строительства для планируемых к вводу в эксплуатацию объектов.

59 Маркерные вещества - вещества, в отношении которых будут рассчитываться технологические нормативы для каждого объекта технологического нормирования и объекта негативно воздействия.

60 Описание метода материального баланса приведено в ИТС по НДТ 22.1-2016 «Общие принципы производственного экологического контроля и его метрологического обеспечения».

URL: http://burondt.ru/NDT/NDTDocsDetail.php?UrlId=815\&etkstructure id=1872 (дата обращения: 01.05.2019). 
Определение значения технологического норматива для выбросов/ сбросов по данному маркерному веществу (т/год) осуществляется путем: умножения технологического показателя выбросов/ сбросов действующего ОТН на величину годового выпуска продукции, если значение ТП по выбросам/ сбросам маркерного вещества действующего ОТН меньше или равно значению ТП НДТ по выбросам/сбросам данного маркерного вещества; умножения ТП НДТ на величину годового выпуска продукции ОТН, если значение ТП выбросов / сбросов маркерного вещества для действующего ОТН превышает значение ТП НДТ этого же маркерного вещества.

Если же ТП НДТ выбросов / сбросов установлены не в виде удельных значений, а в виде концентраций маркерных веществ, то в качестве технологического показателя выбросов/сбросов маркерного вещества ОТН принимается наибольшее значение концентрации данного вещества в выбросах стационарных источников, выпусках сточных вод в составе ОТН, определенных с использованием технической документации; данных инвентаризации выбросов, сбросов; результатов ПЭК.

При этом определение значений ТП и технологических нормативов осуществляется таким образом: а) если значение ТП выбросов/сбросов по маркерному веществу действующего ОТН меныше или равно значению ТП НДТ по этому же веществу, то технологический норматив для данного вещества (т/год) определяется путем умножения удельного значения массы выбросов/ сбросов на величину годового выпуска продукции; б) если значение ТП ОТН маркерного вещества превышает значение ТП НДТ этого вещества, то технологический норматив маркерного вещества (т/год) определяется путем умножения ТП НДТ на годовой объем газовой смеси или годовой расход сточных вод, определяемые согласно программе повыления экологической эффективности.

Для еще не действующих ОТН, а только планируемых к вводу в эксплуатацию ТП выбросов/ сбросов маркерных веществ не могут превышать ТП НДТ; годовые значения технологических нормативов по каждому маркерному веществу (т/год) определяются следующим образом: 1) если ТП НДТ установлены в виде удельных значений массы выбросов/ сбросов маркерных веществ, то значение ТП ОТН принимается равным удельным значениям массы выбросов/ сбросов этого вещества, а технологический норматив определяется путем умножения технологического показателя ОТН на величину годового выпуска продукции; 2) если ТП НДТ установлены в виде кониентраций маркерных веществ, то в качестве технологического показателя ОТН принимается наибольшее значение концентрации данного вещества в выбросах / сбросах ОТН, определенных с помощью технической документации, данных инвентаризации выбросов / сбросов и результатов ПЭК.

Значение технологического норматива (т/год) по конкретному маркерному веществу планируемого к вводу в эксплуатацию ОТН определяется умножением удельного значения массы выбросов/сбросов маркерного вещества на величину годового выпуска продукции. Технологические нормативы по каждому маркерному веществу для объекта НВОС определяются как сумма технологических нормативов всех ОТН в составе объекта НВОС. В приложение к расчетам технологических нормативов могут быть включены обосновывающие расчет сведения и документы, которые природопользователь считает необходимым представить. 


\subsection{3. Технологические показатели наилучших доступных технологий для объектов негативного воздействия на окружающую среду горнодобывающих предприятий}

Необходимым условием для расчета технологических нормативов является наличие утвержденных ТП НДТ в соответствии с видами деятельности, отнесенными к областям применения НДТ. Всего в 2019 г. утверждено 38 нормативных документов для отраслевых (вертикальных) ИТС по НДТ. По виду экономической деятельности «Добыча (и обогащение) полезных ископаемых» предусматриваются ТП НДТ по шести отраслям: добыча и обогащение руд цветных металлов; добыча и обогащение железных руд; добыча нефти; добыча природного газа; добыча и обогащение угля; добыча драгоценных металлов. Например, нормативный документ «Технологические показатели НДТ добычи и обогащения руд цветных металлов», утвержденный Приказом Минприроды России от 2 апреля 2019 г. № 206, устанавливает предельные эмиссии, представленные в таблицах 3.6 (выбросы в атмосферный воздух) и 3.7 (сбросы в водные объекты).

Таблица 3.6

Технологические показатели выбросов загрязняющих веществ в атмосферный воздух НДТ добычи и обогащения руд цветных металлов

\begin{tabular}{|c|c|c|c|}
\hline $\begin{array}{c}\text { Производственный } \\
\text { процесс } \\
\end{array}$ & $\begin{array}{c}\text { Загрязняющее } \\
\text { вещество }\end{array}$ & $\begin{array}{c}\text { Единица } \\
\text { измерения }\end{array}$ & Величина \\
\hline $\begin{array}{l}\text { Разработка месторождений } \\
\text { открытым способом }\end{array}$ & Взвешенные вещества & $\mathrm{M} \Gamma / \mathrm{M}^{3}$ & $\leq 0,5$ \\
\hline $\begin{array}{l}\text { Обогащение руд цветных } \\
\text { металлов }\end{array}$ & $\begin{array}{l}\text { Пыль неорганическая } \\
\text { с содержанием } \\
\text { кремния 20-70 \% }\end{array}$ & $\Gamma / \mathrm{c}$ & $\leq 0,3$ \\
\hline
\end{tabular}

Таблица 3.7

Технологические показатели загрязняющих веществ в сбросах в водные объекты НДТ добычи и обогащения руд цветных металлов

\begin{tabular}{|c|c|}
\hline Загрязняющее вещество & Величина, мг/дм ${ }^{3}$ \\
\hline \multicolumn{2}{|c|}{$\begin{array}{c}\text { Производственный процесс — разработка месторождений открытым и } \\
\text { закрытым способами }\end{array}$} \\
\hline Взвешенные вещества & $\leq 20$ \\
\hline Кадмий & $\leq 0,05$ \\
\hline Медь & $\leq 0,3$ \\
\hline Свинец & $\leq 0,2$ \\
\hline Железо & $\leq 2$ \\
\hline Никель & $\leq 0,5$ \\
\hline Цинк & $\leq 0,5$ \\
\hline Марганец & $\leq 0,08$ \\
\hline Сульфат-анион (сульфаты) & $\leq 1300$ \\
\hline Алюминий & $\leq 0,85$ \\
\hline
\end{tabular}


Подобные технологические показатели НДТ со своими маркерными веществами и их предельными значениями разработаны для остальных справочников НДТ, охватывающих сектор добычи полезных ископаемых. Таким образом, горнодобывающие компании, эксплуатирующие или планирующие вводить в эксплуатацию объекты НBОC I категории, для заявки на получение КЭР должны рассчитать технологические нормативы, используя фактические (для действующих установок), проектные (для вводимых в эксплуатацию установок) и нормативно установленные (соответствующие НДТ) ТП выбросов и сбросов маркерных загрязняющих веществ.

Для снижения эмиссий и минимизации платежей за НBOC горнопромышленная компания должна внедрить НДТ на всех имеющихся объектах I категории, обеспечив непревышение ТП НДТ. Если значения ТП сбросов/выбросов действующего объекта превышают значения ТП НДТ, необходимо разработать программу повышения экологической эффективности с целью поэтапного достижения нормативных значений эмиссий маркерных веществ. Срок действия программы не может превышать семи лет и не подлежит продлению. Ежегодно операторы объектов I категории обязаны сдавать в территориальные органы Росприроднадзора отчеты по результатам осуществления производственного экологического контроля [183].

Как уже было упомянуто, технологические нормативы в настоящее время не установлены в отношении образования и размещения отходов горного производства. Следует подчеркнуть, что технологическое нормирование, как и весь механизм НДТ, в обязательном порядке распространяется только на установки, относящиеся к объектам I категории, а в добровольном - на объекты II категории (при наличии справочников НДС). В этом смысле система нового экологического регулирования является гибридной, сочетая старый и новый подходы для разных категорий объектов НВОС. Несмотря на критику в этом отношении, мы считаем такой компромисс вынужденной мерой в условиях российских реалий, учитывая инерционность институциональных и ментальных традиций в сфере отечественного природопользования.

В текущих условиях стратегия «экологического торможения» наиболее опасных с природоохранной точки зрения действующих производств, которую реализует гибридная система регулирования, выглядит оправданной. Важно добиться работоспособности механизма НДТ, обеспечить выдачу КЭР и инструментальный экологический контроль за состоянием объектов НВОС. В свою очередь, операторы установок НВОС должны разобраться в новых правилах получения разрешений на эксплуатацию установок I и II категорий и научиться оценивать экологическую эффективность результатов своей производственной деятельности.

Так, организации, эксплуатирующие объекты II категории, вместо заявки на получение КЭР обязаны предоставлять в орган Росприроднадзора декларацию о воздействии на ОС, которая в рамках старого экологического регулирования устанавливает нормативы выбросов и сбросов загрязняющих веществ, а также нормативы образования отходов и лимиты на их размещение. Вместе с декларацией подаются расчеты нормативов допустимых выбросов и нормативы допустимых сбросов. При невозможности соблюдения нормативов допустимых выбросов / сбросов составляется план мероприятий по охране $\mathrm{OC}$, предусматривающий их поэтапное достижение. 
Для части горнодобывающих предприятий внедряемая система технологического нормирования создаст определенные сложности. В выгодном положении оказываются те компании, чьи технологии добычи и обогащения полезных ископаемых составителями справочников идентифицированы как НДТ. Это позволяет ожидать, что на действующих объектах технологического нормирования фактические значения ТП выбросов / сбросов маркерных веществ не будут превышать предельные значения ТП НДТ, а значит, плата за НВОС по таким объектам может быть нулевой. В худшем положении окажутся предприятия с объектами технологического нормирования, у которых ТП выбросов/сбросов превысят ТП НДТ, а применяемые технологии не относятся к НДТ. Последним придется разрабатывать программы повышения экологической эффективности и добиваться в процессе их выполнения внедрения НДТ.

Отдельного внимания заслуживают методологические аспекты оценки технологических показателей, а также вопросы экономической эффективности внедрения НДТ на объектах технологического нормирования в составе горнодобывающих предприятий Арктической зоны РФ [137].

\section{4. Информационно-технические справочники по наилучшим доступным технологиям как источники информации для предприятий с объектами первой категории}

\subsection{1. Информационно-технические справочники по наилучшим доступным технологиям и проблема измерения технологических показателей}

Справочники по НДТ обеспечивают заинтересованных лиц необходимой информацией по выбору доступной и наилучшей с экологической точки зрения производственной технологии. В широком смысле они являются периодически обновляемым документированным информационным ресурсом в системе экологического регулирования на основе НДТ, содержание которого представляет собой результат анализа данных, полученных разработчиками справочников от операторов объектов НВОС, других заинтересованных сторон и источников.

В системе взаимодействия по поводу внедрения НДТ наряду с обычными техническими средствами коммуникации участников разработки, актуализации и пользования справочниками по НДТ сами справочники играют роль стратегического коммуникатора между бизнесом, государством и неправительственными экологическими организациями в процессе продвижения концепции НДТ и развития экологического регулирования в целом. В странах с эффективными природоохранными институтами активной стороной в системе стратегических коммуникаций при реализации проектов с НДТ выступают общественные организации.

Согласно Федеральному закону от 29 июня 2015 г. № 162 «О стандартизации в Российской Федерации» информационно-технический справочник - это документ национальной системы стандартизации, содержащий систематизированные данные в определенной области и включающий в себя описание технологий, процессов, методов, способов, оборудования и иные данные. В соответствии с ГОСТ Р 56828.152016 ИТС по НДТ является документом по стандартизации, разработанным в результате анализа технологических, технических и управленческих решений для 
конкретной области применения и содержащим описания применяемых в настоящее время и перспективных технологических процессов, технических способов, методов предотвращения и сокращения НBOC, из числа которых выделены решения, признанные наилучшими. Сама идея разрабатывать ИТС по НДТ как документы по стандартизации основывается на опыте, накопленном российскими экспертами, которые участвовали с конца 1990-х гг. в выполнении проектов в области НДТ и в подготовке ряда национальных стандартов по НДТ [158].

В Российской Федерации, как и в Европейском союзе, разработаны вертикальные (отраслевые) и горизонтальные (межотраслевые) ИТС по НДТ. Горизонтальные справочники по НДТ содержат рекомендации относительно наилучших практик в определенной сфере деятельности (например, в горнодобывающей промышленности ${ }^{61}$, в области утилизации и обезвреживания отходов $^{62}$, в сфере размещения отходов производства и потребления ${ }^{63}$, в сфере очистки сточных вод при производстве продукции ${ }^{64}$ и т. д.). Особенностью горизонтальных справочников по НДТ является то, что они не содержат ТП (аналогов уровней эмиссий, соответствующих НДТ в европейских справочниках, BAT-associated emission levels, BAT-AEL).

Вертикальные (отраслевые) справочники содержат описания технологических процессов, способов, методов предотвращения и сокращения HBOC, a также идентифицируют НДТ для рассматриваемых областей применения с указанием ТП предельных эмиссий маркерных веществ (аналогов уровней эмиссий европейских BAT-AEL). Примеры вертикальных справочников: «ИТС 23-2017. Добыча и обогащение руд цветных металлов», «ИТС 12-2016. Производство никеля и кобальта», «ИТС 24-2017. Производство редких и редкоземельных металлов», «ИТС 30-2017. Переработка нефти», «ИТС 9-2015. Обезвреживание отходов термических способом (сжигание отходов)».

В соответствии с распоряжением правительства РФ ${ }^{65}$ в 2015-2017 гг. был разработан, утвержден и официально выпущен пятьдесят один справочник по НДТ, из них тридцать девять справочников вертикальные, остальные горизонтальные. Российские справочники по НДТ подобны европейским по структуре, содержанию, критериям выбора НДТ и принципам обоснования ТП (уровней эмиссий, соответствующих НДТ). Как в Европейском союзе, так и в Российской Федерации разделы справочников по НДТ, содержащие описание НДТ и уровней эмиссий, соответствующих НДТ, являются ключевыми. Но в отличие от Европейского союза в Российской Федерации, например, не используется такой документ, как заключение НДТ, определенный Директивой 2010/75/EU (IED) [196] и содержащий те части справочников по НДТ (BREF),

${ }^{61}$ ИТС 16-2016. Горнодобывающая промышленность. Общие процессы и методы. М.: Бюро НДТ, 2016.

62 ИТС 15-2016. Утилизация и обезвреживание отходов (кроме обезвреживания термическим способом (сжигание отходов). М.: Бюро НДТ, 2016.

${ }^{63}$ ИТС 17-2016. Размещение отходов производства и потребления. М.: Бюро НДТ, 2016.

64 ИТС 8-2015. Очистка сточных вод при производстве продукции (товаров), выполнении работ и оказании услуг на крупных предприятиях. М.: Бюро НДТ, 2016.

${ }^{65}$ Распоряжение Правительства РФ от 31 октября 2014 г. № 2178-р «Об утверждении поэтапного графика создания в 2015-2017 гг. отраслевых справочников наилучших доступных технологий // ГАРАНT.PУ: сайт. URL: https://www.garant.ru/products/ipo/prime/doc/70685648/ (дата обращения: 24.09.2019). 
которые описывают непосредственно наилучшую доступную технологию. Заключение НДТ имеет силу обязательного для исполнения документа, в то время как справочник НДТ хотя и является официальным изданием, но носит рекомендательный характер.

Некоторые эксперты усматривают определенную аналогию между публикациями заключений по НДТ в формате исполнительных решений Комиссии ЕС и утверждением отраслевых ТП НДТ приказами Минприроды России [118]. Действительно, и в том и в другом случае документу придается нормативный статус. Однако в России утверждаются только ТП эмиссий перечень загрязняющих маркерных веществ и их предельные величины (см. табл. 3.3, 3.4), в то время как публикуемые Комиссией ЕС заключения по НДТ включают всестороннее описание НДТ - уровни эмиссий, оценку применимости, методы производственного контроля, уровни потребления ресурсов и др. (см. подраздел 3.1.2).

В российских отраслевых справочниках НДТ технологические показатели представлены в виде: концентраций загрязняющих веществ в

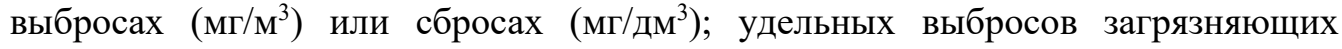
веществ (один килограмм на одну тонну продукции, иногда - сырья); удельного образования отходов; удельного потребления энергии (ГДж/т продукции). Технологические показатели НДТ устанавливаются не позднее шести месяцев после опубликования или актуализации информационнотехнических справочников по НДТ.

Эксперты российского Бюро НДТ [118, с. 73] отмечают проблемные моменты, связанные с использованием и измерением ТП, задаваемых справочниками по НДТ. Например, не вполне ясно, как связать установленные для отрасли ТП (фактически — уровни эмиссий НДТ) и предписываемые в российских разрешительных документах для конкретных предприятий (операторов) значения потоков выбросов, сбросов загрязняющих веществ (т/год, г/c), отходов (т/г). У разработчиков не всегда имеется достаточно данных, чтобы определить и включить в справочник уровни экологической результативности НДТ (уровни выбросов/ сбросов, уровни потребления энергии, воды, сырья, материалов, другие параметры).

Немаловажным вопросом является определение для справочников по НДТ маркерных веществ с целью технологического нормирования. Маркерные вещества позволяют характеризовать применяемые на объекте НВОС технологии и оценивать экологическую результативность производственных процессов. Анализ технологических показателей и сложившейся практики оценивания выбросов / сбросов показывает, что измерения маркерных веществ не всегда позволят достоверно оценивать концентрацию загрязняющих веществ в эмиссии при измерении технологического показателя установки [118].

ГОСТ 56828.15-2016 дает определение маркерного вещества как «выбираемого по определенным критериям наиболее значимого представителя группы веществ, внутри которой наблюдается тесная корреляционная связь». Эта дефиниция плохо работает в целях технологического нормирования, поскольку отсутствуют накопления рядов данных, которые позволили бы оценивать тесноту корреляционных связей между веществами в эмиссии по концентрации для выбора маркеров, объективно отражающих степень загрязненности выбросов / сбросов. 
Этот и другие доводы экспертов говорят о том, что применяемые при составлении справочников по НДТ подходы к выбору маркерных веществ далеко не всегда приемлемы в силу отсутствия статистических баз данных эмиссий для тех или иных условий. Можно заключить, что в отношении инструментального контроля эмиссий объектов НBOC с целью технологического нормирования и осуществления экологического мониторинга наряду с технической проблемой (чем измерять?) и методической проблемой (как измерять?) имеется методологическая проблема (что измерять?), которая, на наш взгляд, может быть решена только совместными усилиями специалистов различных отраслей науки и техники при активной поддержке государства и создании отечественной отрасли экологического приборостроения. Анализ затронутых проблемных аспектов справочников по НДТ подтверждает, что в Российской Федерации НДТ следует рассматривать как инструмент экологической и одновременно промышленной политики.

\subsection{2. Разработка и актуализация информационно-технических справочников по наилучшим доступным технологиям}

В соответствии с законодательством об охране окружающей среды ИТС по НДТ разрабатываются с учетом имеющихся в Российской Федерации технологий, оборудования, сырья, других ресурсов, а также с учетом климатических, экономических и социальных особенностей и отражают текущий уровень эмиссий промышленных предприятий [170]. Основными участниками разработки, актуализации и опубликования ИТС по НДТ являются: федеральные органы исполнительной власти (Минпромторг России, Росстандарт и др.); Бюро НДТ, межведомственный совет (MBC), технические рабочие группы (ТРГ); технический комитет по стандартизации (ТКС); разработчики проектов справочников НДТ.

Порядок определения технологии в качестве НДТ, а также разработки, актуализации и опубликования ИТС по НДТ определен Постановлением Правительства РФ от 23 декабря 2014 г. № 1458 [175]. Минпромторг России осуществляет руководство разработкой и актуализацией ИТС по НДТ и определением технологии в качестве НДТ; своими приказами создает и упраздняет рабочие группы. Росстандарт утверждает и публикует ИТС по НДТ, определяет порядок проведения экспертизы проекта справочника в ТКС и внесения поправок в справочник. Бюро НДТ формирует состав, руководит и координирует деятельность ТРГ, осуществляет сбор и обработку данных для разработки и актуализации ИТС по НДТ, организует публичное обсуждение проектов справочников на официальном сайте бюро, ведет информационные ресурсы и базы данных для разработки и актуализации справочников и определения НДТ.

Технические рабочие группы анализируют данные для определения технологических процессов, оборудования, технических способов и методов в качестве НДТ; согласовывают проекты справочников, формируют для них проекты перечней НДТ и маркерных веществ, предложения по установлению ТП; представляют в информационные ресурсы и базы данных бюро информацию для определения НДТ, разработки и актуализации справочников. MBC снимает разногласия при их наличии, выявленные при разработке и 
актуализации справочников. ТКС проводит экспертизу проектов справочников на соответствие требованиям к их содержанию и структуре как документов национальной системы стандартизации, готовит экспертные заключения на проекты справочников.

Разработчик проекта ИТС по НДТ разрабатывает проект справочника и направляет его в ТРГ, участвует в работе ТРГ, дорабатывает проект справочника по результатам публичного обсуждения и экспертизы в ТКС. Порядок разработки и опубликования справочника по НДТ включает обязательные этапы: формирование рабочей группы и утверждение ее состава; сбор и обработка данных, необходимых для разработки справочника; разработка проекта справочника; рассмотрение и согласование проекта справочника в рабочей группе; публичное обсуждение проекта справочника; экспертиза проекта справочника в техническом комитете; снятие разногласий МВС (при наличии); подготовка к утверждению проекта справочника; утверждение справочника. Ключевой организационной структурой при разработке справочников по НДТ является ТРГ, а одним из наиболее важных этапов разработки является сбор данных для идентификации НДТ.

После размещения на сайте Бюро НДТ уведомления о формировании ТРГ в течение не менее пятнадцати календарных дней заинтересованные лица могут подать заявку на участие в ее работе. К заинтересованным лицам относятся представители промышленных предприятий, федеральных органов исполнительной власти, научно-исследовательских институтов и экспертных организаций, учебных институтов, промышленных ассоциаций, общественных объединений и др. Структурно ТРГ состоит из секретариата, разработчика проекта ИТС по НДТ, полноправных членов и наблюдателей. Состав ТРГ должен быть сбалансирован с учетом области применения ИТС по НДТ и отраслевой специфики; он утверждается для каждого справочника.

Главной целью сбора данных является получение от предприятий, относящихся к областям применения НДТ, реальных данных о применяемых ими технологиях, оборудовании, данных о сбросах / выбросах загрязняющих веществ, образовании отходов, других факторах воздействия на ОС, а также экономических показателях (материальных и организационно-технических затратах на внедрение и эксплуатацию технологии, оборудования).

В России промышленные предприятия осуществляют сбор следующих видов данных [118]: 1) выбросы загрязняющих веществ в воздух, их сбросы в водные объекты (т/год и г/с), образование и размещение отходов (т/год) определяются, прежде всего, на основе действующих разрешений, установленных для максимальной производительности и наименее благоприятных условий рассеивания загрязняющих веществ (для атмосферного воздуха); 3) годовые статистические данные (выбросы, сбросы загрязняющих веществ, образование и размещение отходов), отражающие измеренные или рассчитанные эмиссии и учитывающие реальные объемы производства, выраженные в т/год.

Анкеты рассылаются для сбора данных как на уровне предприятия (что, как правило, не вызывает особых осложнений), так и на уровне технологических процессов, линий. Значительная часть таких сведений на предприятиях не собирается, хотя и может быть систематизирована на основе данных технологических карт, материальных балансов и пр. 
Процесс сбора данных укрупнено состоит из следующих этапов ${ }^{66}$.

1. Разработка унифицированного отраслевого шаблона анкеты (Бюро НДТ).

2. Сбор информации:

a) рассылка на предприятия отрасли утвержденного отраслевого шаблона анкеты по согласованному в рамках ТРГ списку (Минпромторг России);

б) размещение отраслевых шаблонов анкет (доступных для скачивания неограниченному кругу лиц) в открытой части информационного портала Бюро НДТ;

в) консультирование предприятий по заполнению отраслевого шаблона анкеты (эксперты ТРГ);

г) получение заполненных отраслевых анкет от ФОИВ (Бюро НДТ).

3. Обработка и корректировка данных:

a) шифрование (обезличивание) анкет для конфиденциальности;

б) загрузка заполненных анкет в информационную систему «База данных Бюро НДТ»;

в) проверка качества полученных данных (выявление ошибок заполнения);

г) выгрузка данных о предприятиях, применяемых технологиях, данных о выбросах / сбросах загрязняющих веществ, образовании отходов и т. д. в обезличенном виде по сводным формам (графический материал и таблицы).

Предоставленные Бюро НДТ данные используются ТРГ для анализа текущего состояния соответствующей отрасли промышленности, определения технологических процессов, оборудования, технических способов, методов в качестве НДТ, а также для разработки и актуализации ИТС по НДТ в целом. ИТС по НДТ разрабатываются по разделам, каждый из которых проходит этапы рассмотрения, доработки и голосования в рабочем кабинете ТРГ на информационном портале Бюро НДТ.

Разработка проекта ИТС по НДТ начинается параллельно с процессом сбора данных. Первоочередной и ключевой задачей разработки является определение области применения справочника. По завершению сбора данных готовятся остальные разделы ИТС по НДТ в соответствии со стандартизированной структурой, приведенной в ГОСТ Р 56828.14-2016 «НДТ. Структура информационно-технического справочника». Типовая структура отраслевого (вертикального) ИТС по НДТ:

Область применения.

Раздел 1 «Общая информация о рассматриваемой отрасли промышленности».

Раздел 2 «Описание технологических процессов, используемых в настоящее время в рассматриваемой отрасли промышленности».

Раздел 3 «Текущие уровни эмиссии в окружающую среду».

Раздел 4 «Определение наилучших доступных технологий».

Раздел 5 «Наилучшие доступные технологии».

Раздел 6 «Экономические аспекты реализации наилучших доступных технологий».

Раздел 7 «Перспективные технологии», «Заключительные положения и рекомендации», «Приложения», «Библиография».

Структура ИТС по НДТ может незначительно меняться. Однако любое изменение должно быть согласовано в рамках ТРГ и зафиксировано протоколом.

${ }^{66}$ Сайт Бюро наилучших доступных технологий. URL: http://burondt.ru/lpage/ (дата обращения: 10.10.2019). 
Кроме непосредственно самих разделов ИТС по НДТ разрабатываются и утверждаются в ТРГ перечень маркерных веществ, перечень ТП, перечень НДТ. Перечисленные перечни также приводят в приложениях к ИТС по НДТ. Бюро НДТ на основании предложений ТРГ осуществляет публичное обсуждение проекта ИТС по НДТ, а также направляет его на экспертизу в ТКС (ТК 113).

Публичное обсуждение проектов ИТС по НДТ проводится на портале Бюро НДТ. Срок его проведения составляет, как правило, тридцать календарных дней с момента размещения уведомления и проекта справочника на портале Бюро НДТ. Заинтересованные стороны подают замечания и предложения путем заполнения специальной формы с указанием своих контактных данных. В течение десяти рабочих дней с момента завершения публичного обсуждения проекта справочника Бюро НДТ формирует сводку отзывов, в которой приводит решения рабочей группы, принятые по результатам анализа каждого из замечаний.

После завершения публичного обсуждения проекта ИТС по НДТ и его экспертиз (в том числе в ТК 113), проект направляется на доработку в ТРГ. После доработки бюро размещает проект справочника в информационной системе уполномоченного органа для принятия рабочей группой решения о его готовности к утверждению. Росстандарт в десятидневный срок со дня утверждения справочника публикует его в открытом бесплатном доступе на своем официальном сайте. Также ИТС по НДТ публикуется на официальном сайте Бюро НДТ.

Справочники по НДТ имеют ограниченный срок действия. Постановлением Правительства РФ от 23 декабря 2014 г. № 1458 установлено, что не реже чем один раз в десять лет ИТС по НДТ актуализируется. Актуализация осуществляется либо путем разработки нового справочника, либо путем пересмотра отдельных разделов существующего в соответствии с поэтапным графиком, утверждаемым правительством РФ в порядке, аналогичном разработке нового справочника. Основания для актуализации: а) полученные Бюро от ФОИВ, государственных организаций, коммерческих и некоммерческих организаций подтвержденные сведения о новых технологиях, технологическом оборудовании, экономических и экологических показателях, применяемых в отрасли промышленности, результатах законченных научно-исследовательских работ, анализа, изучения и обобщения отечественного и зарубежного опыта; б) необходимость изменения области применения справочника и/или включения в него сведений о процессах, оборудовании, технических способах и методах определения технологии в качестве наилучшей доступной, которые не были учтены ранее; в) приведение содержания справочника в соответствие с изменениями, внесенными в федеральные законы и иные нормативные правовые акты Российской Федерации, а также с заключенными международными соглашениями в течение десятилетнего периода; г) поручение правительства Российской Федерации об актуализации соответствующего справочника.

В целом процесс разработки ИТС по НДТ в Российской Федерации аналогичен процессу, принятому в Европейском союзе, однако есть и различия, в частности $[118$, с. 58$]$ : в России анализируется и учитывается опыт Бюро IPPC, но российский процесс разработки ИТС по НДТ следует принципам разработки национальных стандартов; в России справочники разрабатываются в гораздо более сжатые сроки: подготовка проекта ИТС по НДТ занимает три - четыре месяца; обязанности членов ТРГ, требования к структуре и содержанию ИТС по НДТ 
установлены не единым документом (как в Европейском союзе), а национальными стандартами; перечень стандартов последовательно расширяется.

Для оперативного обмена информацией по вопросам НДТ в Российской Федерации, как и в Европейском союзе, созданы цифровые информационные платформы. Российский портал Бюро НДТ выполняет те же функции, что и европейская информационная система НДТ (BATIS). Официальный сайт Бюро IPPC (http://eippcb.jrc.ec.europa.eu) является основным инструментом распространения НДТ (BREF) и их проектов в странах ЕС. Официальный сайт российского Бюро НДТ (www.burondt.ru) позволяет получить доступ к информации о законодательстве в области НДТ и КЭР, методическим документам, утвержденным ИТС по НДТ и их проектам (на стадии публичного обсуждения). В обеих информационных системах есть открытые и закрытые части. В России право доступа к закрытой части портала Бюро НДТ предоставлено только сотрудникам Бюро НДТ и членам ТРГ; другие заинтересованные стороны могут следить за ходом разработки проектов справочников НДТ, посещая открытую часть портала.

\subsection{3. Анализ информационно-технических справочников по наилучшим доступным технологиям в области добычи твердых полезных ископаемых}

Из тридцати девяти отраслевых (вертикальных) справочников НДТ шесть относится к виду экономической деятельности «Добыча полезных ископаемых». К этому же виду деятельности относится один межотраслевой (горизонтальный) справочник (табл. 3.8).

Таблица 3.8

Справочники НДТ, распространяющиеся на добычу полезных ископаемых

\begin{tabular}{|c|c|c|c|c|}
\hline $\begin{array}{l}\text { Номер } \\
\text { ИТС }\end{array}$ & Обозначение & Наименование & Вид & $\begin{array}{c}\text { Дата и номер } \\
\text { приказа } \\
\text { Росстандарта об } \\
\text { утверждении } \\
\end{array}$ \\
\hline 16 & ГДП & $\begin{array}{l}\text { «Горнодобывающая } \\
\text { промышленность. } \\
\text { Общие процессы и } \\
\text { методы» }\end{array}$ & $\Gamma$ & $\begin{array}{c}15 \text { декабря } 2016 \text { г. } \\
\text { № } 1886\end{array}$ \\
\hline 23 & ДРЦМ & $\begin{array}{l}\text { «Добыча и обогащение } \\
\text { руд цветных металлов» }\end{array}$ & B & $\begin{array}{c}15 \text { декабря } 2017 \text { г. } \\
\text { № } 2839\end{array}$ \\
\hline 25 & ЖР & $\begin{array}{l}\text { «обыча и обогащение } \\
\text { железных руд» }\end{array}$ & B & $\begin{array}{c}15 \text { декабря } 2017 \text { г. } \\
\text { № } 2845\end{array}$ \\
\hline 37 & ДОУ & $\begin{array}{l}\text { «Добыча и обогащение } \\
\text { угля» }\end{array}$ & B & $\begin{array}{c}15 \text { декабря } 2017 \text { г. } \\
\text { № } 2841 \\
\end{array}$ \\
\hline 49 & ДДМ & $\begin{array}{l}\text { «Добыча драгоценных } \\
\text { металлов» }\end{array}$ & B & $\begin{array}{c}15 \text { декабря } 2017 \text { г. } \\
\text { № } 2846\end{array}$ \\
\hline 28 & ДН & «Добыча нефти» & B & $\begin{array}{c}15 \text { декабря } 2017 \text { г. } \\
\text { № } 2838\end{array}$ \\
\hline 29 & ДПГ & $\begin{array}{l}\text { «Добыча природного } \\
\text { газа» }\end{array}$ & B & $\begin{array}{c}15 \text { декабря } 2017 \text { г. } \\
\text { № } 2844\end{array}$ \\
\hline
\end{tabular}


Из указанных в табл. 3.8 справочников к добыче ТПИ относятся пять: ИТС 16-2016, ИТС 23-2017, ИТС 25-2017, ИТС 37-2017, ИТС 49-2017. Первым был разработан межотраслевой справочник по НДТ «Горнодобывающая промышленность. Общие процессы и методы», он положил начало серии справочников для предприятий горнодобывающей промышленности. Наименование у этого справочника вначале было другое - «Обращение с вскрышными и вмещающими горными породами» - по аналогии с европейским справочником по НДТ по управлению хвостами обогащения и породными отходами, образующимися в результате горнодобывающей деятельности ${ }^{67}$.

Смену наименования ИТС 16-2016 (и концепции) разработчики объяснили неполным охватом справочником по обращению с вскрышными и вмещающими горными породами экологических аспектов горной добычи и подготовкой четырех отраслевых справочников в области добычи ТПИ (ИТС 232017, ИТС 25-2017, ИТС 37-2017, ИТС 49-2017). Такой подход, как указывают И. С. Курошев, П. А. Макеенко, М. В. Доброхотова, позволил подготовить один общий всеобъемлющий горизонтальный справочник (т. е. имеющий сквозной характер и предназначенный для всех предприятий горнодобывающего сектора) и компактные справочники для отдельных отраслей, что обеспечило удобство их использования. При этом авторы отмечают общий характер описанных в ИТС 16-2016 методов и технологий, которые могут быть нереализуемы на конкретном добывающем предприятии в силу горно-геологических (или иных) особенностей [63].

В разделе 5 «Наилучшие доступные технологии» ИТС 16-2016 для всей области применения справочника выделено десять аспектов, в соответствии с которыми даны описания групп НДТ: организационно-управленческого и организационно-технического характера; НДТ в областях энергосбережения и ресурсосбережения, производственного контроля, минимизации негативного воздействия на атмосферный воздух, минимизации негативного воздействия физических факторов, минимизации негативного воздействия на водные ресурсы, минимизации воздействия отходов горнодобывающих предприятий, рекультивации земель, нарушенных в процессе ведения горнодобывающих работ, минимизации негативного воздействия на ландшафты, почвы и биологическое разнообразие.

Идентифицированные как НДТ технологии отражают общие подходы и методы снижения воздействия на ОС процессов добычи и обогащения ТПИ. Они также задают направления конкретизации НДТ в отраслевых ИТС. Всего в справочнике содержатся шестьдесят описаний НДТ, которые выделены в самостоятельное приложение. Поскольку справочник горизонтальный, приведенные в нем НДТ не содержат маркерных веществ и количественных ТП.

В качестве примера отраслевого НДТ кратко рассмотрим справочник ИТС 23-2017 «Добыча и обогащение руд цветных металлов». В соответствии с преамбулой ИТС 23 содержит описание применяемых при добыче и обогащении руд и россыпей цветных металлов и отходов горно-металлургических

${ }^{67}$ Reference Document on Best Available Techniques for Management of Tailings and WasteRock in Mining Activities, EC, 2009. (MTWR BREF). URL: https://eippcb.jrc.ec.europa.eu/reference/BREF/mmr_adopted_0109.pdf (accessed: 11.09.2019). 
производств технологических процессов, оборудования, технических способов, методов, в том числе позволяющих снизить НВОС, потребление воды и сырья, повысить энергоэффективность. Из представленных в справочнике решений определены решения, являющиеся НДТ, установлены ТП НДТ, где это необходимо и возможно.

Положения справочника ИТС 23-2017 распространяется: на добычу и обогащение руд и россыпей цветных металлов; добычу и обогащение отходов горно-металлургических производств; технологические процессы, применяемые при добыче и обогащении руд и россыпей цветных металлов и отходов их переработки. Справочник также распространяется на процессы, связанные с основными видами деятельности, которые могут оказать влияние на объемы эмиссий и/или масштабы загрязнения ОС: производственные процессы добычи и обогащения; методы предотвращения и сокращения эмиссий и образования отходов; хранение и транспортировку продукции, пустой породы и хвостов обогащения.

Информация, относящаяся непосредственно к металлургическому комплексу цветных металлов, содержится в ИТС по НДТ, описывающих вид экономической деятельности «Обработка»: производство меди (ИТС 3-2015), алюминия (ИТС 11-2016), никеля и кобальта (ИТС 12-2016), свинца, цинка и кадмия (ИТС 13-2016), драгметаллов (ИТС 14-2016), редких и редкоземельных металлов (ИТС 24-2017). Процесс добычи и обогащения руд цветных металлов предполагает дополнительные виды деятельности в аспекте НДТ. Они охватываются другими справочниками НДТ, которые могут быть как отраслевыми, так и межотраслевыми. В справочнике ИТС 23-2017 выделены три вида дополнительной деятельности, связанные с отходами основной деятельности: 1) методы очистки сточных вод, направленные на сокращение сбросов металлов в водные объекты (предлагается применять ИТС 8-2015); 2) обращение с отходами (предлагается применять ИТС 15-2016); 3) хранение и обработка материалов (предлагается применять ИТС 46-2017).

Раздел 5 справочника ИТС 23-2017 «Наилучшие доступные технологии» содержит краткое описание идентифицированных как НДТ технологий для процессов добычи и обогащения руд, в том числе технические и технологические решения и методы минимизации НBОC при добыче открытым и подземным способами, рудоподготовке и обогащении. Описаны технологии обращения с отходами и побочными продуктами производства, обеспечивающие рост ресурсосбережения и энергоэффективности, снижение уровня эмиссий загрязняющих веществ в ОС. Раздел 5 также выделяет несколько подразделов с технологиями, определенными как НДТ:

5.1. Системы экологического менеджмента (НДТ 1)

5.2. НДТ, направленные на снижение НВОС при добыче руд цветных металлов (НДТ $2 \div 12)$

5.3. НДТ, направленные на снижение НВОС при обогащении руд цветных металлов (НДТ $13 \div 21)$

5.4. Технологии обращения с отходами обогащения руд (НДТ $22 \div 25)$

5.5. НДТ в области энергосбережения и ресурсосбережения (НДТ $26 \div 133)$

5.6. НДТ в области рекультивации земель (НДТ $34 \div 39)$

5.7. Противоаварийные мероприятия (НДТ $40 \div 46)$ 
Всего описано сорок шесть НДТ. Описания, как правило, короткие и носят общий характер; ТП предусмотрены всего в трех НДТ из сорока шести при оценке выбросов в атмосферу воздуха и сбросов в водные объекты. Отходы вскрыши и вмещающих пород упоминаются лишь в контексте возможности использования при рекультивации нарушенных земель (НДТ 36) и в неявной форме - вовлечения в производство (НДТ 12). Примеры описания НДТ:

НДТ 12. Вовлечение отходов во вторичное производство. НДТ предусматривает использование отходов добычи и переработки в производстве, например, строительных материалов, а также в качестве средств рекультивации.

НДТ 14. Улавливание выбросов по возможности максимально близко к источнику с последующей их очисткой.

НДТ 20. Снижение выбросов пыли от стационарных источников. НДТ заключается в снижении выбросов пыли на всех участках, где возможно ее образование, в том числе грохочение, дробление, классификация в воздушной среде, усреднение руд, рудосортировка, обжиг и сушка, путем применения одного из методов: рукавного фильтра, мокрого скруббера, циклона, мокрого электрофильтра. Маркерное вещество: пыль неорганическая (20-70\% $\mathrm{SiO}_{2}$ ). Технологический показатель: $\leq 0,3$ г/с.

НДТ 36. Использование отходов при рекультивации нарушенных земель, в том числе: вскрышных и вмещающих пород; хвостов добычи; отходов цветной металлургии; золошлаков; прочих отходов IV и V классов опасности.

Справочник ИТС 23-2017 «Добыча и обогащение руд цветных металлов» распространяется на добычу и обогащение отходов горно-металлургических производств, но не вполне ясно, каким образом, поскольку в пятом разделе, где перечислены все НДТ, этот вид отходов не упоминается.

В отношении отходов добычи и обогащения руд цветных металлов ИТС 23-2017 не предусматривает применение межотраслевого справочника ИТС 17-2016 «Размещение отходов производства и потребления», область применения которого охватывает хранение отходов добычи и обогащения. По дополнительному виду деятельности «Обращение с отходами» при добыче и обогащении цветных металлов в ИТС 23-2017 указан лишь справочник ИТС 152016 «Утилизация и обезвреживание отходов (кроме обезвреживания термическим способом (сжигание отходов)». Возникает коллизия, учитывая, что ИТС 23-2017 — отраслевой справочник, ИТС 17-2016 — межотраслевой, а размещение отходов - это составляющая обращения с отходами.

Более того, межотраслевой ИТС 15-2016 распространяется на утилизацию и обезвреживание отходов, но отходы добычи и обогащения полезных ископаемых отсутствуют в перечне групп отходов, деятельность по обезвреживанию и утилизации которых рассматривается в данном справочнике. Очевидно, необходимо внести поправку в ИТС 23-2017 и предусмотреть применение ИТС 17-2016 для обращения с отходами добычи и обогащения вместо ИТС 15-2016.

Разработанные справочники НДТ охватывают не все подотрасли добычи ТПИ. Например, осталась неохваченной вертикальными справочниками добыча горно-химического сырья. При этом ОКВЭД 2 выделяет добычу полезных ископаемых для химической промышленности и производства минеральных удобрений в отдельную группировку видов экономической деятельности, а производство агрохимических продуктов отнесено к первой категории объектов НВОС и рассмотрено в ИТС 02-2015. Описание в ИТС 02-2015 технологических схем 
начинается с приема уже подготовленного минерального сырья (твердой или жидкой серы, апатитового концентрата, поташа) за исключением производства хлористого калия (рассмотрены рудоподготовка и технологии обогащения калийных руд) ${ }^{68}$. В Постановлении Правительства РФ от 28 сентября 2015 г. № 1029 указано, что производство агрохимических продуктов относится к I категории объектов по НВОС, а вот добыча и подготовка исходной руды не рассматривается.

Ожидает своего описания для выявления НДТ добыча руд редких и редкоземельных металлов - первого в цепочке добавленной стоимости сегмента создаваемой в стране редкоземельной промышленности полного технологического цикла ${ }^{69}$. Справочник ИТС 24-2017 «Производство редких и редкоземельных металлов» не распространятся на добычу и обогащение руд и продуктов, содержащих РЗМ и редкие металлы.

Межотраслевой справочник ИТС 17-2016 «Размещение отходов производства и потребления» охватывает технологии (методы, способы, средства, оборудование), применяемые при размещении отходов на объектах, предназначенных: для хранения отходов добычи и обогащения (отвалы, хранилища), отходов обрабатывающих производств, захоронения отходов добывающих, обрабатывающих и иных производств, захоронения ТКО. В справочнике рассматриваются технические, технологические и организационные мероприятия, направленные на предотвращение и/или снижение загрязнений ОС применительно к объектам размещения отходов при их строительстве, эксплуатации, консервации и ликвидации. Понятие «утилизация отходов» применительно к отходам добычи в разделе «Область применения» не употребляется, упор делается на размещении, которое рассматривается по этапам жизненного цикла ОРО: проектирование и строительство, эксплуатация, закрытие / консервация или ликвидация. Технологическими операциями при эксплуатации ОРО являются транспортировка, подготовка отходов к размещению, размещение, обращение с водами, обращение с выбросами. Размещение рассматривается как складирование отходов и осуществляется на объектах, которые являются природно-охранными сооружениями, обеспечивающими снижение или предотвращение воздействия размещенных отходов на ОС.

На наш взгляд, недостатком справочника ИТС 17-2016 является его слишком широкий межотраслевой охват областей применения, который, очевидно, требует дифференциации в отношении отходов недропользования, по крайней мере отходов добычи и обогащения ТПИ, вносящих основной вклад в накопление отходов. Объединение в одном справочнике НДТ различных видов экономической деятельности, а точнее, их побочных результатов (поскольку речь идет о хранении и

68 ИТС 02-2015 «Производство аммиака, минеральных удобрений и неорганических кислот», с. 755-807. http://webportalsrv.gost.ru/portal/gostnews.nsf/acaf7051ec840948c22571290059c78f/4f7d066a72e2 776d44257d2d00264aa1/\$FILE/ITS_po_ndt_02.pdf (дата обращения: 10.11.2019).

${ }^{69}$ Государственная программа Российской Федерации «Развитие промышленности и повышение ее конкурентоспособности до 2020 года»: утв. Решением Правительства РФ от 15 апреля 2014 г. № 328, паспорт подпрограммы 15 «Развитие промышленности редких и редкоземельных металлов» // Государственная система правовой информации. Официальный интернет-портал правовой информации. URL: http://pravo.gov.ru/proxy/ips/? docbody $=\& n d=102352828 \& \mathrm{rdk}=\&$ backlink=1 (дата обращения: 07.11.2019). 
образовании отходов), не позволяет на должном уровне углубиться в технологическую специфику ГПО как объекта регулирования и управления.

Смешение различных по своей природе, ресурсному потенциалу и экологическим последствиям таких объектов регулирования, как отходы добычи минерального сырья, отходы промышленного производства (обработки) и потребления (ТКО), приведет к тому, что ГПО не получат должного внимания со стороны регулятора и проблема снижения их накопления, использования как техногенных ресурсов останется нерешенной [55]. По нашему мнению, необходимо создание отдельного справочника НДТ, охватывающего деятельность по обращению с ГПО (управлению отходами недропользования). Это позволит с единых позиций подойти к экологическому регулированию добычи ТПИ и обращению с ГПО на основе НДТ в границах вида деятельности «Добыча полезных ископаемых».

Разработчики серии справочников НДТ для предприятий горнодобывающей промышленности при формировании состава данной серии ориентировались на европейский опыт, учитывая, по всей видимости, не только масштабы и структуру горнодобывающей промышленности в России, но и сложившееся у горнодобывающих компаний отношение к обращению с отходами добычи.

Как было сказано, первоначально при проектировании серии справочников по НДТ для предприятий горнодобывающей промышленности планировалось взять за основу европейский справочный документ НДТ по обращению с хвостами обогащения и пустыми породами в горнодобывающей деятельности (MTWRBREF). Однако от этого отказались, поскольку справочный документ MTWRBREF изначально был направлен на предотвращение аварий с тяжелыми экологическими последствиями на отвалах и хвостохранилищах и, по мнению российских разработчиков ИТС по НДТ, он неполно охватывал экологические аспекты горной добычи [63].

Действительно, официально опубликованный в 2009 г. справочный документ MTWRBREF создавался в Евросоюзе в 2001-2004 гг., еще до принятия Директивы 2006/21/ЕС об управлении отходами горнодобывающей промышленности, на основе Сообщения Европейской комиссии СОМ (2000) 664 о безопасности горнодобывающей деятельности при обращении с хвостами обогащения и пустыми породами. На MTWRBREF не распространялось действие Директивы по промышленным выбросам 2010/75/EU. Однако с 2015 по 2017 гг. справочник MTWRBREF был пересмотрен в рамках Севильского процесса с позиций стратегии циркулярной экономики ${ }^{70}$ адаптированно к Директиве 2006/21/ЕС. Справочник обновился с учетом появления новых технологических разработок, возникновения новых проблем и получения новых данных об управлении отходами добычи, включая добычу нефти и газа на суше.

Проект обновленного справочника по НДТ, который получил сокращенное название MWEI BREF ${ }^{71}$, был открыт для комментариев в июне

\footnotetext{
${ }^{70}$ Waste and recycling // Joint Research Centre. URL: https://susproc.jrc.ec.europa.eu/ activities/waste/index.html (accessed: 12.09.2019).

${ }^{71}$ Best Available Techniques Reference Document for the Management of Waste from Extractive Industries // European Commission. URL: https://eippcb.jrc.ec.europa.eu/reference/BREF/ jrc109657_mwei_bref__for_pubsy_online.pdf (accessed: 01.09.2019).
} 
2016 г. $^{72}$, а после их обработки, завершения технических обсуждений и редактирования Комиссия ЕС в декабре 2018 г. официально опубликовала обновленный справочный документ по НДТ об обращении с отходами добывающей промышленности. Новый 692-страничный справочник по НДТ отличается глубиной научной проработки, структурированностью и конкретностью описания методов предотвращения, уменьшения воздействия и снижения потенциального риска для ОС и здоровья человека, возникающих в результате обращения с отходами добывающей промышленности, с акцентом на измеримость экологических показателей.

Содержание MWEI BREF включает общую информацию о добывающем секторе Европы, экологических проблемах обращения с отходами добычи, обзор методов обращения с отходами, данные о показателях экологической деятельности установок, уровнях эмиссий и потребления, методы предотвращения или уменьшения воздействия и потенциального риска для ОС при обращении с отходами добычи, заключения по НДТ. Определение НДТ в справочнике MWEI BREF осуществлялось посредством выявления экологических проблем в секторе добычи, изучения наиболее подходящих методов для решения ключевых вопросов, определения достижимых уровней экологической эффективности и условий их достижения на практике (включая экономические издержки, перекрестные эффекты и иные движущие силы, указанные в ответах на опросные анкеты).

Таким образом, обновленный европейский справочный документ MWEI BREF по обращению с отходами добывающей промышленности отличается от предшествовавшего ему документа MTWRBREF расширенной областью применения, большей полнотой охвата актуальных проблем в сфере обращения c отходами горнодобывающих предприятий, качеством показателей экологической эффективности. Новый справочный документ органично вписался в принятую в конце 2015 г. Комиссией ЕС концепцию (пакет) циркулярной экономики, имеющей целью повышение конкурентоспособности, создание рабочих мест и обеспечение устойчивого роста ${ }^{73}$. Механизм НДТ можно рассматривать как один из основных движителей, способствующих реализации концепции циркулярной экономики в горнодобывающем секторе.

Российские разработчики серии справочников по НДТ для предприятий горнодобывающей промышленности определяли состав серии и ее содержание в части отходов добычи еще до появления обновленного европейского документа MWEI BREF и принимали во внимание лишь устаревший к тому времени документ MTWRBREF (пункт 8 библиографии ИТС 16-2016). Произвольное для различных ТРГ «размывание» методов обращения с отходами горного производства по отраслевым справочникам НДТ при отсутствии по меньшей мере четко структурированного межотраслевого шаблона рассмотрения обращения с отходами добычи и обогащения в настоящее время уже нельзя считать оптимальным решением. На наш взгляд, имеется необходимость создания интегрированного справочника НДТ по обращению с отходами недропользования в контексте

\footnotetext{
${ }^{72}$ MWEI BREF draft document // European Commission. URL: https://susproc.jrc.ec.europa.eu/ activities/waste/documents/MWEI_BREF_Draft.pdf (accessed: 10.10.2019).

${ }^{73}$ Circular Economy Package to boost competitiveness, create jobs and generate sustainable growth // European Commission. URL: https://ec.europa.eu/commission/presscorner/detail/en/ IP_15_6203 (accessed: 10.10.2019).
} 
выделения сферы обращения с отходами горнодобывающих производств в отдельный предмет экологического регулирования.

\section{5. Комплексные экологические разрешения и декларации в системе экологического регулирования объектов первой и второй категорий}

\subsection{1. Нормативная правовая база комплексных экологических разрешений и деклараций о воздействии на окружающую среду}

Федеральным законом от 21 июля 2014 г. № 219-Ф3 в Федеральный закон от 10 января 2002 г. № 7-Ф3 «Об охране окружающей среды» были внесены изменения, которыми было введено понятие «комплексное экологическое разрешение». Статья 1 Федерального закона № 7-Ф3 определяет КЭР как документ, который выдается уполномоченным федеральным органом исполнительной власти юридическому лицу или индивидуальному предпринимателю, осуществляющим хозяйственную и (или) иную деятельность на объекте, оказывающем НBOC, и содержит обязательные для выполнения требования в области охраны ОС.

С 1 января 2019 г. вступила в силу статья 31.1 Федерального закона № 7-Ф3, определяющая ключевые аспекты КЭР, касающиеся содержания заявки на получение, порядка подачи заявки уполномоченному правительством РФ федеральному органу исполнительной власти, условий рассмотрения заявки и выдачи КЭР, а также условий продления, пересмотра и отзыва КЭР. Федеральным органом исполнительной власти, уполномоченным выдавать КЭР, является Федеральная служба по надзору в сфере природопользования (Росприроднадзор).

Закон предусматривает, что КЭР обязаны получить юридические лица и индивидуальные предприниматели, осуществляющие хозяйственную и/или иную деятельность на объектах I категории. В то же время КЭР вправе получить юридические лица и индивидуальные предприниматели, осуществляющие хозяйственную и/или иную деятельность на объектах II категории при наличии соответствующих отраслевых (вертикальных) ИТС по НДТ. Срок действия КЭР семь лет, оно может быть продлено при соблюдении определенных установленных федеральным законом № 7-Ф3 условий. Таким образом, с 1 января 2019 г. КЭР стало единым разрешительным документом для предприятий, в том числе горных, на эксплуатацию объектов НВОС I категории (объектов со значительным негативным воздействием) в системе экологического регулирования, базирующейся на механизме НДТ и технологическом нормировании.

В конце 2018 г. произошли изменения, внесенные Федеральным законом от 25 декабря 2018 г. № 496-Ф3, в котором указано, что разрешительные документы, полученные на объекты I и II категорий до 1 января 2019 г., действуют до дня истечения срока их действия либо до дня получения КЭР или представления ДВОС. При этом с 1 января 2019 г. и до получения КЭР объектами I категории допускается выдача разрешительных документов по старой схеме.

Утвержден список трехсот объектов ОНВ, вклад которых в суммарные выбросы, сбросы по стране составляет не менее чем 60 \%. Объекты из данного списка обязаны подать заявку на получение КЭР с 1 января 2019 г. по 31 декабря 2022 г., остальные объекты I категории до 1 января 2025 г. обязаны получить КЭР. Паспортом федерального проекта «Внедрение наилучших доступных 
технологий» национального проекта «Экология» предусмотрено получение пятнадцати КЭР в 2019 г.

Федеральным законом № 7-Ф3 (пункт 10 статьи 31.1) [170] определено, что КЭР содержит: технологические нормативы; нормативы допустимых выбросов, сбросов высокотоксичных веществ, веществ, обладающих канцерогенными, мутагенными свойствами (веществ I, II класса опасности), при наличии таких веществ в выбросах загрязняющих веществ, сбросах загрязняющих веществ; нормативы допустимых физических воздействий; нормативы образования отходов и лимиты на их размещение; требования к обращению с отходами производства и потребления; согласованную программу производственного экологического контроля; срок действия КЭР.

На объектах НВОС, где реализуются программы повышения экологической эффективности, КЭР может дополнительно содержать ВРВ и ВРС. Сама программа повышения экологической эффективности является неотъемлемой частью КЭР. Нормативы образования отходов и лимитов на их размещение согласуются в соответствии с Федеральным законом от 29 декабря 2014 г. 458-Ф3 [166].

В соответствии с пунктом 1 статьи 31.2 федерального закона № 7-Ф3 юридические лица, индивидуальные предприниматели, осуществляющие хозяйственную и/или иную деятельность на объектах II категории, представляют деклараиию о воздействии на окружаюшую среду (ДВОС). Как и КЭР, ДВОС представляется раз в семь лет при условии неизменности технологических процессов основных производств, качественных и количественных характеристик выбросов, сбросов загрязняющих веществ и стационарных источников. Если изменения произошли до истечения семи лет, необходимо актуализировать сведения об объекте HBOC, получить новое свидетельство на объект, а затем подать обновленную декларацию. Рекомендации по проведению актуализации ДВОС содержатся в письме Росприроднадзора от 16 марта 2017 г. № AC-03-04-36/528774. В отношении объектов, подлежащих федеральному государственному экологическому надзору, декларация представляется в территориальные органы Росприроднадзора, в отношении иных объектов - в органы исполнительной власти субъектов РФ. Уровень надзора определяется в соответствии с требованиями Постановления Правительства России от 28 августа 2015 г. № 903 [176].

Федеральным законом № 7-Ф3 (пункт 2 статьи 31.2) определено, что ДВОС по отношению к юридическому лицу должна содержать: наименование, организационно-правовую форму и адрес / место нахождения юрлица; код объекта, оказывающего НBOC; вид основной деятельности, виды и объем производимой продукции (товара); информацию о реализации природоохранных мероприятий; данные об авариях и инцидентах, повлекших за собой НВОС и произошедших за предыдущие семь лет; декларируемые объем или массу выбросов, сбросов

\footnotetext{
74 Письмо Росприроднадзора от 16 марта 2017 г. № АС-03-04-36/5287 «Об актуализации учетных сведений объектов НВОС» (с Методическими рекомендациями по актуализации учетных сведений об объекте НВОС, включенном в государственный реестр, Методическими рекомендациями по снятию с государственного учета объектов HBOC) // КонсультантПлюс: сайт. URL: http://www.consultant.ru/document/cons_doc_LAW_214467/_ (дата обращения:
} 10.11.2019). 
загрязняющих веществ, образовываемых и размещаемых отходов; информацию о программе производственного экологического контроля.

Руководители горнодобывающих и других компаний, эксплуатирующих объекты НВОС II категории, должны знать, что если сфера деятельности этих объектов входит в область применения НДТ, имеются соответствующие отраслевые справочники и утвержденные технологические показатели НДТ, то владельцы таких объектов вправе получить КЭР для всех или некоторых из объектов. При этом для объекта II категории должны быть определены технологические и другие нормативы согласно требованиям КЭР, a предоставление ДВОС не потребуется. Это может оказаться целесообразным, например, в случае, если у компании есть объекты I и II категорий и компания реализует широкомасштабную программу перехода на НДТ.

Декларация о воздействии на окружающую среду будет устанавливать нормативы выбросов и сбросов загрязняющих веществ, а также нормативы образования отходов и лимиты на их размещение. Исходя из системного толкования новых редакций статьей 4 закона об охране окружающей среды и статьей 18 закона об отходах производства и потребления для объектов II категории все же должны осуществляться расчеты НООЛР, однако их приложение к декларации не требуется. При этом, как следует из информационного письма Росприроднадзора от 12 октября 2018 г. № АА-03-02-31/21799, дополнительное утверждение производимых расчетов в контролирующих органах и получение разрешений с 1 января 2019 г. не предусмотрено.

Одновременно с подачей ДВОС представляются pacчеть нормативов допустимых выбросов, нормативов допустимых сбросов. С 1 января 2019 г. полномочия Росприроднадзора по установлению нормативов и выдаче отдельных разрешений прекращены. Из статьи 22 Закона «Об охране окружающей среды» следует, что: 1) нормативы допустимых выбросов и нормативы допустимых сбросов определяются для стационарного источника и/или их совокупности в отношении установленного правительством РФ перечня загрязняющих веществ расчетным путем на основе нормативов качества ОС, в том числе нормативов предельно допустимых концентраций, с учетом фонового состояния компонентов природной среды; 2) расчет нормативов допустимых выбросов и нормативов допустимых сбросов производится юридическими лицами и индивидуальными предпринимателями, планирующими строительство объектов I и II категорий (при проведении оценки воздействия на ОС), а также осуществляющими хозяйственную и/или иную деятельность на объектах II категории; 3) расчет нормативов допустимых выбросов и нормативов допустимых сбросов, за исключением радиоактивных веществ, является приложением к ДВОС; 4) методики и/или методы разработки нормативов допустимых выбросов и нормативов допустимых сбросов утверждаются уполномоченным правительством РФ федеральным органом исполнительной власти; 5) 10 апреля 2019 г. был представлен на государственную регистрацию в Минюст России Приказ Минприроды России от 25 января 2019 г. № 49 «Об утверждении Методов разработки нормативов допустимых выбросов 
вредных (загрязняющих) веществ в атмосферный воздух» ${ }^{75}$ (на ноябрь 2019 г. не было сведений об утверждении методик и/или методов расчета указанных выше нормативов).

Минприроды России письмом от 30 ноября 2018 г. № 12-50/09939-ОГ сообщило, что Федеральным законом от 21 июля 2014 г. № 219-Ф3 не предусматривается отмена действия разрешений на выбросы в атмосферный воздух, сбросы в водные объекты, а также НООЛР, выданных в установленном порядке до 1 января 2019 г. $^{76}$. Специалисты Экологического центра сложившуюся ситуацию прокомментировали так: «Закончился 2018 год, и вместе с ним ушли в прошлое ПДВ, НДС, НООЛР в привычном для нас виде; и хотя документация появилась новая, она во многом схожа со старыми формами экологического нормирования. Как и экологи, которые по привычке тянутся мыслить категориями ПДВ, НДС и НООЛР, чиновники, создающие подзаконные акты по внедрению новой стратегии экологического развития страны, тоже пытаются сохранить привычный порядок вещей» ${ }^{77}$. Очевидно, до утверждения новых методик нормирования в отношении объектов II категории следует ориентироваться на старые методики расчетов ПДВ, НДС, НООЛР.

Следует иметь в виду, что проект ПДВ разрабатывается в соответствии с Инструкцией по инвентаризации выбросов загрязняющих веществ в атмосферу, утвержденной Приказом Минприроды России от 6 июня 2017 г. № 273, а также с помощью Методического пособия по расчёту, нормированию и контролю выбросов загрязняющих веществ в атмосферный воздух, 2012. Срок действия инструкции истек в апреле 2019 г., взамен установлен порядок, содержащийся в Приказе № 352 от 7 августа 2018 г. Проект НДС разрабатывается в соответствии с Приказом Министерства природных ресурсов и экологии Российской Федерации от 17 декабря 2007 г. № 333. Проект НООЛР разрабатывается и утверждается для предприятий, относящихся к федеральному уровню надзора в соответствии с Приказом Минприроды России от 25 февраля 2010 г. № 50 и Методикой разработки проекта НООЛР, утвержденной Приказом Минприроды России от 5 августа 2014 г. № 349; для объектов регионального уровня надзора — в порядке, установленном местными органами исполнительной власти ${ }^{78}$.

75 Об утверждении методов разработки нормативов допустимых выбросов вредных (загрязняющих) веществ в атмосферный воздух // Экология производства: научнопрактический портал. URL: http://www.ecoindustry.ru/news/view/55127.html (дата обращения: 10.11.2019).

76 Письмо Минприроды России от 30 ноября 2018 г. № 12-50/09939-ОГ «Об изменениях законодательства Российской Федерации в сфере охраны окружающей среды» // КонсультантПлюс: сайт. URL: http://www.consultant.ru/law/hotdocs/56007.html/ (дата обращения: 10.11.2019).

77 Новая жизнь старых проектов ПДВ, НДС, ПНООЛР // Экологический центр: сайт. URL: $\quad$ https://eco-cntr.ru/blog/novosti/novaya-zhizn-staryh-proektov-pdv-nds-pnoolr-2019 (дата обращения: 10.11.2019).

${ }^{78}$ Как получить КЭР и ДВОС в 2019 году - актуальная информация // Экопромцентр. 18.02.2019. URL: http://ecopromcentr.ru/kehr-i-dvos/ (дата обращения: 10.11.2019). 


\subsection{2. Содерэание заявки на получение комплексного экологического разрешения и декларации об объектах негативного воздействия на окружающую среду}

Форма заявки на получение КЭР и форма самого разрешения утверждена приказом Минприроды России от 11 октября 2018 г. № $510^{79}$, который вступил в силу с 1 января 2019 г. Заявка состоит из восьми разделов, каждый из которых посвящен определенному виду воздействия на ОС, которое оказывает объект НВОС. Оформить заявку нельзя без свидетельства о постановке на учет объекта НВОС и разработанных ранее проектов по отходам и выбросам, сбросам (ПНООЛР, НДС, ПДВ). Обязательна также разработанная и утвержденная программа ПЭК.

Заявка на получение КЭР содержит следующую информацию (для юридического лица): 1) наименование юрлица, организационно-правовая форма, место нахождения, адрес; 2) код объекта, вид основной деятельности, виды и объем производимой продукции (товара); 3) сведения об использовании сырья, воды, электрической и тепловой энергии; 4) данные об авариях и инцидентах за последние семь лет, которые негативно повлияли на ОС; 5) информацию о реализации программы повышения экологической эффективности (при ее наличии); 6) расчеты технологических нормативов; 7) при наличии в выбросах и сбросах веществ I, II класса опасности (радиоактивных, высокотоксичных, обладающих канцерогенными и мутагенными свойствами) - расчеты нормативов допустимых выбросов и сбросов; 8) обоснование НООЛР; 9) проект программы ПЭК; 10) сведения о наличии положительного заключения государственной экологической экспертизы (если она обязательна); 11) иную информацию, которую заявитель желает представить.

Если заявитель не может соблюсти нормативы воздействия на ОС (например, нормативы допустимых выбросов, сбросов высокотоксичных веществ, пункт 4 статьи 31.1 Закона «Об охране окружающей среды»), к заявке необходимо приложить: проект ППЭЭ, разработанной в соответствии со статьей 67.1 Федерального закона от 10 января 2002 г. № 7-Ф3 «Об охране окружающей среды» (в частности, в программу следует включить перечень мероприятий по реконструкции, техническому перевооружению объекта, сроки их выполнения); план по снижению объема или массы ВРВ и ВРС загрязняющих веществ, который должен включать фактические данные (на момент подачи заявки на получение КЭР), а также на период реализации ППЭЭ и после нее.

Приказом Минприроды России от 11 октября 2018 г. № 509 определена форма ДВОС для объектов II категории и порядок ее заполнения ${ }^{80}$. Декларация состоит из семи разделов и включает восемь таблиц:

Раздел I. Таблица «Виды и объем производимой продукции (товара)»

Раздел II. Таблица «Информация о реализации природоохранных мероприятий»

\footnotetext{
79 Приказ Минприроды России от 11 октября 2018 г. № 510 «Об утверждении формы заявки на получение комплексного экологического разрешения и формы комплексного экологического разрешения».

80 Приказ Минприроды России от 11.10.2018 № 509 «Об утверждении формы декларации о воздействии на окружающую среду и порядка ее заполнения, в том числе в форме электронного документа, подписанного усиленной квалифицированной электронной подписью».
} 
Раздел III. Таблица 3.1 «Данные об авариях, повлекших негативное воздействие на окружающую среду, произошедших за ... годы»,

таблица 3.2 «Данные об инцидентах, повлекших негативное воздействие на окружающую среду, произошедших за ... годы»

Раздел IV. Таблица «Масса выбросов загрязняющих веществ»

Раздел V. Таблица «Масса сбросов загрязняющих веществ»

Раздел VI. Таблица 6.1 «Масса или объем образовавшихся и размещенных отходов»,

таблица 6.2 «Масса или объем образовываемых и размещаемых отходов

Раздел VII. «Информация о программе производственного экологического контроля»

Приложениями к декларации являются: расчет нормативов допустимых выбросов; расчет нормативов допустимых сбросов.

Разделы IV-VI заполняются юридическими лицами (и индивидуальными предпринимателями), осуществляющими хозяйственную и/или иную деятельность, оказывающую негативное воздействие на, соответственно, атмосферный воздух и водные объекты, а также осуществляющие деятельность, связанную с образованием и/или размещением отходов. Данные об объемах производимой продукции (товаров), единицах измерения приводятся на основании данных бухгалтерского учета и/или иных документов, содержащих информацию о планируемых видах и объемах производимой продукции на период действия декларации. Наименования, виды и коды производимой продукции приводятся в соответствии с Общероссийским классификатором продукции по видам экономической деятельности (ОКПД2) ОК 034-2014 (КПЕС 2008).

Раздел II заполняется по результатам реализации действующего до подачи декларации плана мероприятий по охране ОС, раздел III - на основании сведений о произошедших за предыдущие семь лет авариях и инцидентах, повлекших за собой HBOC. В Разделе III, в части данных об авариях, повлекших за собой НВОС, указываются для каждой аварии: дата возникновения и ликвидации (или планируемая дата) последствий; краткая характеристика аварии с указанием причин ее возникновения; краткая характеристика видов НВОС при аварии; размер вреда, причиненного ОC; основные мероприятия по локализации и ликвидации последствий. В части данных об инцидентах, повлекших за собой $\mathrm{HBOC}$, для каждого инцидента указывается то же, что и об авариях.

Раздел IV заполняется на основании расчета нормативов допустимых выбросов, а раздел $\mathrm{V}$ - на основании расчета НДС, расчеты прилагаются к декларации.

Раздел VI в части массы или объема образовавшихся и размещенных отходов заполняется в соответствии с пунктом 4 статьи 18 Федерального закона от 24 июня 1998 г. № 89-Ф3 «Об отходах производства и потребления» на основании данных учета образовавшихся, утилизированных, обезвреженных, переданных другим лицам или полученных от других лиц, а также размещенных отходов. Данные представляются за календарный год, предшествующий году представления декларации. Раздел VI в части массы или объема образовываемых и размещаемых отходов заполняется на основании данных, содержащихся в проектах НООЛР.

Раздел VII заполняется на основании программы ПЭК, утвержденной в соответствии с Приказом Минприроды России от 28 февраля 2018 г. № 74 «Об 
утверждении требований к содержанию программы производственного экологического контроля, порядка и сроков представления отчета об организации и о результатах осуществления производственного экологического контроля».

\subsection{3. Выдача, продление, пересмотр и отзыв комплексного экологического разрешения}

Постановлением Правительства РФ от 13 февраля 2019 г. № 143 установлены Правила выдачи, переоформления и отзыва КЭР [179]. КЭР выдается территориальным органом Федеральной службы по надзору в сфере природопользования (Росприроднадзором) на основании заявки на получение разрешения, которая подается владельцем объекта НВОС I категории на отдельный объект (в том числе линейный) в территориальный орган Росприроднадзора по месту размещения объекта НВОС. Заявка должна содержать информацию, установленную пунктом 3 статьи 31.1 Федерального закона № 7-Ф3 «Об охране окружающей среды» [170].

Территориальный орган Росприроднадзора в течение пяти рабочих дней проверяет форму и содержание заявки на соответствие требованиям ФЗ № 7-ФЗ. При соответствии формы и содержания заявки, а также прилагаемых к ней материалов требованиям Ф3 № 7-Ф3 заявитель письменно информируется о приеме заявки к рассмотрению, при несоответствии - об отказе в рассмотрении заявки. Орган Росприроднадзора не вправе требовать от заявителя иных материалов, кроме указанных в пункте 3 статьи 31.1 Ф3 № 7-Ф3 (см. пункты 1-11 в подразделе 3.5.2).

В случае приема заявки на получение КЭР к рассмотрению территориальный орган Росприроднадзора в течение пяти рабочих дней размещает ее на своем официальном сайте, обеспечивая к ней свободный доступ заинтересованных лиц. Одновременно в течение этих пяти дней орган Росприроднадзора запрашивает у территориального органа Роспотребнадзора копии документов, подтверждающих соответствие информации, включаемой в состав заявки в соответствии с абзацем 9 части 3 статьи 31.181 Федерального закона Ф3 № 7-Ф3 «Об охране окружающей среды», санитарно-эпидемиологическим требованиям в случаях, установленных Федеральным законом «О санитарно-эпидемиологическом благополучии населения».

Орган Роспотребнадзора готовит и направляет ответ в течение пяти рабочих дней со дня поступления запроса. При этом заявитель вправе по собственной инициативе представить в территориальный орган Росприроднадзора указанные выше копии документов. Территориальный орган Росприроднадзора в течение двадцати пяти календарных дней после приема заявки к рассмотрению, но не позднее чем в месячный срок со дня ее получения выдает заявителю разрешение при условии подтверждения соответствия информации, включаемой в состав заявки в соответствии с абзацем 9 части 3 статьи 31.1 Ф3 № 7-Ф3. Территориальный орган

\footnotetext{
${ }^{81}$ Ф3 № 7-Ф3, статья 31.1, часть 3, абзац 9: «Расчеты нормативов допустимых выбросов, нормативов допустимых сбросов радиоактивных, высокотоксичных веществ, веществ, обладающих канцерогенными, мутагенными свойствами (веществ I, II класса опасности), при наличии таких веществ в выбросах, сбросах загрязняющих веществ».
} 
Росприроднадзора отказывает заявителю в выдаче КЭР по основанию, предусмотренному абзацем 2 пункта 9 статьи 31.1 ФЗ № 7-Ф3 ${ }^{82}$.

Комплексное экологическое разрешение продлевается на семь лет при соблюдении заявителем совокупности условий, предусмотренных пунктом 13 статьи 31.1 Ф3 № 7-Ф3 ${ }^{83}$.

Комплексное экологическое разрешение подлежит пересмотру частично или полностью в случаях, если на объекте НВОС изменены технологические процессы основных производств, заменено оборудование (сырье) и это повлекло за собой изменение установленных объема или массы выбросов загрязняющих веществ, сбросов загрязняющих веществ, лимитов на размещение отходов производства и потребления. Если установленные объемы или массы выбросов загрязняющих веществ, сбросов загрязняющих веществ, лимитов на размещение отходов производства и потребления увеличились не более чем на 70 \%, КЭР пересматривается частично, а если на 70 \% и более - полностью.

Пересмотр КЭР оформляется по форме заявки на получение КЭР. Если КЭР пересматривается частично, заявителю выдается приложение к КЭР, содержащее обязательные для исполнения требования и являющееся неотъемлемой частью имеющегося разрешения. В случае если КЭР пересматривается полностью, то выдается новое разрешение.

Комплексное экологическое разрешение подлежит переоформлению в случаях, предусмотренных пунктом 17 статьи 31.1 Федерального закона «Об охране окружающей среды» (в случае замены юридического лица в форме преобразования, изменения его наименования, адреса / места нахождения). При этом осуществляется актуализация учетных сведений об объекте НBOC (в соответствии со статьей 69.2 ФЗ № 7-Ф3).

По инициативе заявителя, получившего КЭР, органом Росприроднадзора в КЭР вносятся изменения, если такие изменения не затрагивают указанные в пунктах 10 и 11 статьи 31.1 Федерального закона «Об охране окружающей

82 Ф3 № 7-Ф3, статья 31.1, абзац 2, пункт 9: «Основанием для отказа в выдаче КЭР являются отсутствие в составе заявки на получение КЭР информации и документов, указанных в пунктах 3 и 4 настоящей статьи, несоответствие этих информации и документов установленным требованиям». Пункт 3 статьи 31.1: «Заявка на получение комплексного экологического разрешения должна содержать следующую информацию...» (см. пункты 111 на получение КЭР выше)». Пункт 4 статьи 31.1: «...проект программы повышения экологической эффективности; планируемые временно разрешенные выбросы, временно разрешенные сбросы с указанием объема или массы выбросов загрязняющих веществ, сбросов загрязняющих веществ на текущий момент, на период реализации программы повышения экологической эффективности и после ее реализации».

83 Ф3 № 7-Ф3, статья 31.1, пункт 13: «КЭР выдается сроком на семь лет и продлевается на тот же срок при совокупности условий: соблюдения установленных технологических нормативов, нормативов допустимых выбросов, нормативов допустимых сбросов высокотоксичных веществ, веществ, обладающих канцерогенными, мутагенными свойствами (веществ I, II класса опасности), при наличии таких веществ в выбросах, сбросах загрязняющих веществ, лимитов на размещение отходов производства и потребления; отсутствия задолженности по плате за негативное воздействие на окружающую среду; своевременного представления отчетности о выполнении программы производственного экологического контроля, уведомлений об авариях, повлекших за собой негативное воздействие на окружающую среду; выполнения программы повышения экологической эффективности в установленные сроки (при ее наличии)». 
среды» условия разрешения (нормативы, требования к обращению с отходами, согласованную программу ПЭК, срок действия КЭР, ВРВ, ВРС, ППЭЭ).

Комплексное экологическое разрешение подлежит отзыву в случаях нарушения в течение шести месяцев и более установленных разрешением обязательных требований при осуществлении деятельности без его пересмотра, а также в случае снятия объекта НВОС с государственного учета. С требованием отзыва КЭР территориальный орган Росприроднадзора обращается в суд.

\section{Выводы по главе 3}

Одной из основных причин промышленных загрязнений является несовершенство производственных технологий, а отходы производства становятся непосредственными источниками негативного воздействия. Суть европейской модели защиты ОС от промышленных загрязнений заключается в стремлении государства законодательно обеспечивать предотвращение образования технологических отходов и последовательное снижение уровня их негативного воздействия на природную среду. Комплексность подхода к предотвращению и контролю загрязнений подразумевает интегрированную оценку объекта НВОС по всем видам технологических отходов одновременно. В основе европейской модели лежит идея использования НДТ, системы технологического нормирования эмиссий и получения комплексных разрешений на эксплуатацию установок. Концепщия НДТ увязывает экологический, технологический и экономический факторы использования установок (объектов НВОС) и действия операторов установок.

В странах ЕС управление отходами добывающих отраслей промышленности законодательно выведено из-под действия Рамочной директивы об отходах, однако лишь в той части, которая охватывается Директивой об управлении отходами горнодобывающей промышленности, которая, в свою очередь, отражает принципы и приоритеты, определенные Рамочной директивой об отходах в соответствии с концепцией устойчивого развития. Таким образом, управление обращением с отходами горнодобывающей промышленности в странах ЕС регулируется в рамках экологического права. В этой связи нельзя согласиться с теми, кто предлагает в России вывести из сферы действия Закона «Об отходах...» отношения по использованию отходов горнодобывающего и связанных с ним перерабатывающих производств (техногенных образований) и регламентировать эти отношения только законодательством о недрах. Европейская модель регулирования не может служить основанием для таких предложений.

Вводимое в России по аналогии с европейской моделью государственное экологическое регулирование нацелено на обеспечение экологической безопасности промышленных производств посредством внедрения НДТ. При этом в тени остается вопрос создания и обновления самих НДТ, которые и должны обеспечивать комплексную защиту ОС от негативных воздействий технологических отходов, образующихся при производстве товарной продукции горнодобывающих и иных производств. Таким образом, ключевым остается вопрос разработки инновационных решений, которые впоследствии получат статус наилучших доступных.

В 2018 г. правительством РФ утверждена Стратегия развития промышленности по обработке, утилизации и обезвреживанию отходов производства и потребления на период до 2030 года, которая предполагает формирование отходоперерабатывающей отрасли промышленности. Новая отрасль должна 
объединить экономически и организационно взаимосвязанных хозяйствующих субъектов, осуществляющих деятельность по вовлечению отходов в хозяйственный оборот, превращению их во вторичное сырье для изготовления продукции и получения энергии. По замыслу в инфраструктуру новой отрасли войдут организации и учреждения, занимающиеся научными исследованиями и разработкой инновационных технико-технологических решений в сфере ресурсосбережения, обработки, утилизации и обезвреживания отходов, а также предприятия, выпускающие соответствующее оборудование и установки. Представляется, что в рамках системы управления недропользованием это направление должно быть выделено как предмет скоординированного внимания Минприроды России и Минпромторга России.

В связи с принятием концепции НДТ и категорированием промышленных объектов НВОС изменена система платы за НВОС для объектов I категории, которая теперь взимается за выбросы загрязняющих веществ в атмосферный воздух, сбросы их в водные объекты и размещение отходов с применением стимулирующих коэффициентов. Некоторые аспекты ее применения в отношении отходов добычи полезных ископаемых остаются открытыми.

Ключевой новацией является введение технологического нормирования выбросов и сбросов загрязняющих (маркерных) веществ, установление технологических нормативов на эмиссии для объектов I категории и получение в органе Росприроднадзора КЭР на эксплуатацию таких объектов. Технологическое нормирование, как и весь механизм НДТ, в обязательном порядке распространяется только на установки, относящиеся к объектам I категории, в добровольном - на объекты II категории (при наличии справочников НДС). В этом смысле система нового экологического регулирования является гибридной, сочетая старый и новый подходы для разных категорий объектов НВОС. Несмотря на критику, мы считаем такой компромисс в условиях российских реалий вынужденной и оправданной мерой, учитывая инерционность институциональных и ментальных традиций в сфере отечественного природо- и недропользования.

Важно добиться работоспособности механизма НДТ, обеспечить выдачу КЭР и инструментальный экологический контроль состояния объектов НВОС горнодобывающих предприятий. В отношении инструментального контроля эмиссий объектов НВОС с целью технологического нормирования и осуществления экологического мониторинга наряду с технической проблемой «чем измерять?» и методической проблемой «как измерять?» имеется методологическая проблема «что измерять?». Данная проблема, на наш взгляд, носит основополагающий с точки зрения результативности характер и может быть решена только совместными усилиями специалистов различных отраслей науки и производства при активной поддержке государства в рамках создания отечественной отрасли экологического приборостроения.

Рассмотрены справочники по НДТ, вопросы их разработки и актуализации, выполнен их анализ в области добычи ТПИ. Отдельный раздел посвящен КЭР и декларациям в системе экологического регулирования объектов I и II категорий, содержанию деклараций и структуре заявок на получение КЭР. Отдельно рассмотрены некоторые аспекты выдачи, продления, пересмотра и отзыва КЭР. 


\section{4. МЕТОДОЛОГИЧЕСКИЕ АСПЕКТЫ ОБОСНОВАНИЯ И ОЦЕНКИ ЭКОНОМИЧЕСКОЙ ЭФФЕКТИВНОСТИ КОМПЛЕКСНОГО ИСПОЛЬЗОВАНИЯ ТЕХНОГЕННЫХ МИНЕРАЛЬНО-СЫРЬЕВЫХ РЕСУРСОВ}

\section{1.Методологические подходы к оценке экономической эффективности комплексного использования техногенного минерального сырья}

\subsection{1. Проблема комплексного недропользования и оценки экономической эффективности переработки многокомпонентного минерального сырья}

Анализ литературных источников по вопросам теории и методологии оценки экономической эффективности комбинированного комплексного использования многокомпонентного природного и техногенного минерального сырья показал, что основной вклад в разработку научных основ технологии и экономики рационального недропользования, комбинированного комплексного освоения ресурсов недр внесли отечественные ученые и специалисты: М. И. Агошков, А. С. Астахов, А. Х. Бенуни, В. И. Вернадский, В. Н. Виноградов, Т. А. Гатов, И. М. Грацерштейн, В. Т. Калинников, Г. Д. Кузнецов, Ф. Д. Ларичкин, В. Н. Лексин, Н. В. Мельников, А. Первушин, В. А. Резниченко, К. Н. Трубецкой, В. А. Федосеев, А. Е. Ферсман, В. А. Чантурия [1, 5, 8, 19, 20, 26, 36, 50, 57, 62, 66, $70,73,74,100,128,129,130,132,133,145]$.

Зарубежные исследователи, такие как К. Друри, Д. Хан, С. Fontain, H. Court, H. Culmann, M. De Narbonn, L. Lawrence, C. Schlatter, K. Slater, C. Wootton $[39,135,152,153,155,157,160,163,164]$, терминологию и понятие комплексного использования сырья практически не используют и исследуют в основном только распределение совокупных затрат комбинированного комплексного производства между основным (целевым) и попутными (побочными, сопутствующими) продуктами (компонентами).

При этом точки зрения по исключительно сложным фундаментальным и прикладным аспектам экономики рационального недропользования, комбинированной комплексной переработки многокомпонентного минерального сырья, высказанные в разные годы в различных социально-экономических условиях в большей степени носят узкоотраслевой, ведомственный характер, зачастую являются противоречивыми. В литературе и практической работе широко используются термины и понятия основного (главного) и nопутных (conутствующих, т. е. второстепенных) ценных компонентов многокомпонентного сырья, которые в большинстве случаев не соответствуют их значимости для конкретных предприятий, особенно для экономики страны, поскольку не имеют строго научного обоснования. Суть проблемы и критический анализ различных точек зрения исследователей и законодателей на понятие «попутные полезные ископаемые» и «попутные полезные компоненты» рассмотрены ниже, в разделе 4.4.

Важнейшие методологические вопросы по дифференцированной стоимостной оценке и определению экономической эффективности извлечения и производства каждого из ценных компонентов минерального сырья, особенно попутных, остаются слабо исследованными, неясными, противоречивыми, 
вследствие чего необходимо их теоретическое переосмысление, обобщение и развитие в соответствии с современными условиями хозяйствования.

Определяющее, ключевое значение для социо-эколого-экономической эффективности большинства конкретных проектов в области рационального недро-, природопользования имеют основополагающие ноосферная теория академика В. И. Вернадского (рациональное научное преобразование биосферы в ноосферу сферу разума - на основе законов сохранения и поддержания жизни с целью гармоничного сосуществования природы и общества) и теория комплексного использования всей совокупности ценных составляющих и свойств минерального сырья на принципах эколого-экономической эффективности академика А. Е. Ферсмана.

Разнообразные виды ГПО, как и природное минеральное сырье, имеют сложный многокомпонентный состав, проблемы их рационального использования рассматриваются как составная часть проблемы комплексного природо-, недропользования (М. И. Агошков, А. Х. Бенуни, В. И. Вернадский, И. М. Грацерштейн, В. Т. Калинников, Ю. А. Киперман, М. А. Комаров, Г. Д. Кузнецов， Ф. Д. Ларичкин， В. Н. Лексин， Н.В.Мельников， Б. К. Михайлов, В. А. Резниченко, В. А. Федосеев, А. Е. Ферсман) $[1,8,19,36,50,57,62,66,70,73$, $74,124,132,133]$.

В современной концепции рационального природопользования особое место занимают экологические аспекты (М. И. Агошков, А. Х. Бенуни, С. Н. Бобылев， В. И. Вернадский， Э.В.Гирусов， Ф. Д. Ларичкин， В.Н.Лексин, Н. В. Мельников, В. А. Резниченко, К. Н. Трубецкой, А. Е. Ферсман, Г.Н. Харитонова, В.А. Чантурия), что требует учета экологических эффектов, достигаемых в результате повышения полноты комплексного использования природного и техногенного сырья.

В этой связи рациональность недропользования обусловлена не только поиском, разработкой и внедрением инновационных технических и технологических решений, но и методологической обоснованностью сравнительной оценки экономической эффективности множества альтернативных вариантов и выбора наилучшего, в частности, оценки экономической эффективности освоения каждого из природных и техногенных георесурсов (в том числе каждого из его ценных составляющих!) в отдельности и комбинированного комплексного использования всей совокупности георесурсов конкретного участка недр при данных социально-экономических условиях. Только так можно выявить экономически оптимальные направления и варианты освоения отдельных участков недр и соответствующих им ресурсов, целесообразность и экономическую эффективность извлечения, производства и использования каждого из ценных составляющих в определенный период развития национальной экономики, а также обеспечить нормальное функционирование и развитие территорий сырьевой специализации, минерально-сырьевого комплекса страны в целом.

Формирование эффективной системы недропользования, в основе которой заложено комбинированное комплексное освоение и использование всей совокупности ресурсов недр, применение малоотходных ресурсосберегающих технологий, экологизация производства и обеспечение конкурентоспособности продукции МСК на мировом рынке, не может рассматриваться как однократное действие. Его следует рассматривать как сложный, многоэтапный, непрерывный итерационный процесс, который 
требует глубоких теоретических, методологических исследований, обобщений, моделирования и практических проработок, а также диагностики, координации, мониторинга, контроля и коррекции. Необходим учет специфики и закономерностей комплексных производств, включая пересмотр традиционных подходов и понимания многих экономических категорий, принципов, методов и оценок.

На основании обобщения литературных источников [66] можно выделить четыре исторически сложившиеся принципиально отличные методологические подхода к исследованию и решению экономических проблем КИМС: дискриминационный (все затраты на производство приходятся на основной компонент за минусом стоимости попутных, себестоимость и эффективность производства которых при таком подходе не может быть выявлена); бухгалтерский (косвенные затраты распределяются между всеми компонентами на основе стоимостных параметров без учета физико-химических и технологических различий); технократический (косвенные затраты распределяются на основе натуральных технических, физических, химических параметров компонентов и технологий их извлечения при игнорировании стоимостных); нигилистский (отрицается принципиальная возможность обоснованного научного подхода к определению индивидуальных стоимостных параметров продуктов (компонентов) комплексной переработки многокомпонентного сырья).

Недостатки и ограниченность каждого из этих подходов обусловливают необходимость применения системного междисциплинарного подхода к исследованию сложных взаимосвязанных проблем комбинированного комплексного освоения и использования многокомпонентного природного, техногенного, нетрадиционного минерального сырья, включая разнообразные ГПО (т. е. всей совокупности ресурсов недр). При этом требуется учет геологических, технологических, экономических, социальных, экологических и природоохранных аспектов по всему циклу изъятия, переработки и использования ресурсов недр, а также размещения, хранения, обращения с отходами по принципу «от земли до земли». Вместе с тем целесообразно отказаться от разделения на основные и попутные ценные составляющие (компоненты) сырья, ресурсов недр, которое не имеет строго научного обоснования и в определенной степени препятствует позитивному решению проблемы.

Любой продукт (компонент), который пользуется спросом с экономической точки зрения для рынка, национальной экономики, предприятия равнозначен, в том числе содержащийся в исходном сырье в мизерных количествах (например, редкие, рассеянные и редкоземельные элементы), но имеющий техническую возможность извлечения и используемый в прогрессивных наукоемких производствах, таких, например, как ракетно-космический, оборонный комплексы и др. Все ценные компоненты минерального сырья предлагается обозначать термином «сопряженные» как экономически равноценные.

Установлено [66], что основная специфическая особенность экономики комбинированных комплексных многономенклатурных производств состоит в том, что высокая экономическая эффективность комплексного использования многокомпонентного сырья (минерального, растительного, биологического и т. д.) в целом не свидетельствует, однако, об эффективности производства каждого из содержащихся в нем ценных составляющих (компонентов), фактически 
извлекаемых в готовую конечную продукцию, и наоборот. В связи с этим необходима не только общая оценка эффективности комплексного использования ресурса в целом, но и дифференцированная оченка экономической эффективности получения каждого из ценных компонентов в отдельности, т. е. требуется определение рационального круга ценных составляющих сырья, подлежащих извлечению.

Повсеместно используемый традиционный подход к решению проблемы основан на окупаемости полной себестоимости оцениваемого компонента, что характерно для монопродуктовых предприятий, вследствие этого не учитывается специфика комбинированных комплексных многономенклатурных производств. Это на практике приводит к завышению затрат, которые необходимы для организации производства каждого отдельного компонента, и к необоснованному, резкому сужению экономически эффективных границ комплексного использования природных и техногенных минеральных ресурсов.

\subsection{2. Структурный анализ экономических факторов производственных моделей переработки многокомпонентного минерального сырья}

Теоретически эколого-экономические преимущества комплексного использования георесурсов, природа положительного синергетического эффекта могут быть выявлены и наглядно представлены при сравнительном анализе принципиально возможных моделей [66] индивидуального (монопродуктового), интегрированного (конгломератного типа - производства отдельных компонентов технологически не связаны между собой) и комбинированного (комплексного) производств, организуемых на базе одного и того же месторождения многокомпонентного минерального сырья (рис. 4.1).

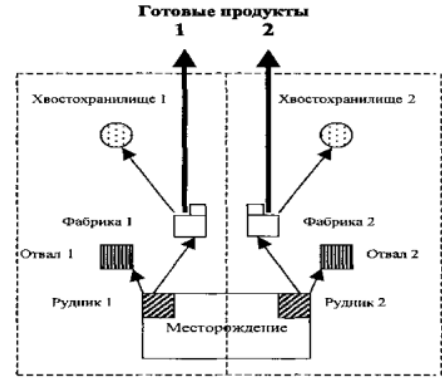

1. Индивидуальное производство (монопродуктовое)

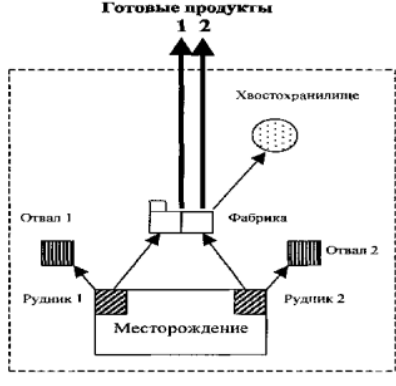

2. Интегрированное производство (конгломерат)

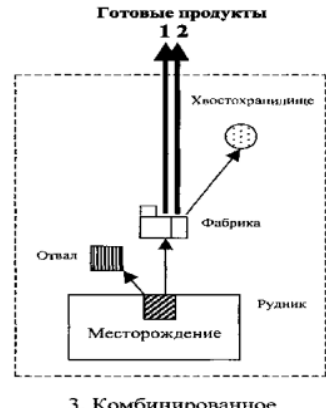

3. Комбинированное

Рис. 4.1. Разновидности моделей производств при использовании многокомпонентного сырья [66]

Особенности формирования совокупных издержек и доходов производств, соответствующих перечисленным моделям (в расчете на равные объемы и качество конечных продуктов), при извлечении из сырья хотя бы двух, а тем более большинства или всех ценных компонентов в обособленные готовые продукты, обусловлены следующими обстоятельствами. Расширение номенклатуры извлекаемых полезных компонентов при переработке многокомпонентного сырья сопровождается преобразованием только части перерабатывающих мощностей на 
стадии обогащения или чаще всего на заключительных химико-металлургических операциях переработки концентратов, полуфабрикатов, промежуточных продуктов. При этом не требуется увеличения объема добычи сырья, следовательно, текущих затрат и дополнительных инвестиций, связанных с подготовкой сырьевой базы, горными работами и начальными стадиями подготовки сырья к переработке (т. е. с процессами дробления, измельчения, классификации и т. п.).

В структуре стоимости готовых продуктов, получаемых из минерального сырья, наиболее дорогостоящими, капиталоемкими, энергоемкими и трудоемкими являются процессы добычи (главным образом в совокупности с подготовкой сырьевой базы, транспортировкой, дроблением и измельчением руды), которые не меняются при изменении количества (перечня) извлекаемых ценных компонентов и уровня их извлечения. Наряду с этим повышение уровня комплексного использования сырья в большинстве случаев обеспечивает относительное (в расчете на равный конечный народнохозяйственный результат) и абсолютное сокращение негативного воздействия горнопромышленного предприятия на ОС, т. е. могут иметь социальный и экологический эффекты.

Вместе с тем экономические и экологические преимущества комплексного использования сырья, а также потенциальный синергетический эффект требуют подтверждения соответствующими экономическими расчетами в каждом конкретном случае. Как организация извлечения новых компонентов, так и повышение полноты использования любого ценного компонента сырья связаны с дополнительными издержками и экономически оправданы только при определенных условиях их окупаемости. Необходимо иметь в виду, что получение продукции из комплексного сырья в объемах сверх потребностей народного хозяйства с учетом возможного экспорта (имеющийся совокупный рыночный спрос на внутреннем и внешнем рынках) даже при несущественных дополнительных затратах экономически нецелесообразно. К тому же нецелесообразно получение такой продукции при комплексной переработке сырья, которая может быть выработана из аналогичного или принципиально другого вида сырья с более высокими технико-экономическими показателями. Другими словами, синергетический эффект становится отрицательным при повышении уровня комплексного использования конкретного многокомпонентного сырья сверх экономически оправданного уровня. Кроме того, освоение комплексного месторождения нецелесообразно, если тот же набор продукции и в те же сроки можно произвести с меньшими издержками при освоении совокупности более простых мономинеральных месторождений.

Следует отметить важную особенность использования ГПО: в сравнении с использованием природного минерального сырья, относительная величина совокупных косвенных затрат на добычу и подготовку к комплексной утилизации техногенного сырья - ГПО (особенно отходов обогащения) - существенно ниже. 


\subsection{3. Методика оценки экономической эффективности извлечения компонентов и комплексного использования техногенного минерального сырья}

Авторами обоснована и рекомендована методика [66] оценки экономической эффективности комплексного использования ТМС - отходов недропользования, включающая два этапа: 1) предварительная оценка экономической эффективности извлечения каждого из ценных компонентов сырья в отдельности, которая определяется из условия возмещения только прямых производственных затрат, связанных с организацией извлечения оцениваемого компонента, без учета косвенных расходов; 2) окончательная оценка экономической эффективности комплексной утилизации техногенного сырья в целом, которая выявляется из условия возмещения общей суммы прямых и косвенных затрат на добычу и комплексную переработку сырья при учете только тех компонентов, извлечение которых экономически оправдано в соответствии с принципом этапа 1.

Формально перечисленные принципы рекомендуемой методики оценки эффективности извлечения каждого из ценных составляющих и комплексного использования многокомпонентного ТМС с учетом основных положений действующих методических рекомендаций по оценке эффективности инвестиционных проектов [81] могут быть выражены следующей системой неравенств:

$$
\left\{\begin{array}{l}
\sum_{t=0}^{T}\left(L_{i t}-3_{n i t}-K_{n i t} \pm \Im_{i t}\right)(1+E)^{-t} \geq 0 \\
\text { чДД }=\sum_{t=0}^{T}\left(L_{t}-3_{t}-K_{t} \pm Э_{t}\right)(1+E)^{-t} \geq 0
\end{array},\right.
$$

где Ц $i t$ - цена $i$-го компонента в готовой продукции в году $t ; 3_{n i t}, \mathrm{~K}_{n i t}-$ прямые соответственно текущие и единовременные затраты на производство $i$ го компонента в готовой продукции в году $t$; $Э_{i t}-$ экологическая составляющая (учитывающая и выгоды, и затраты) извлечения $i$-го компонента из сырья в году $t$ (может быть положительной и отрицательной); $~_{t}$ экономический результат (общая стоимость реализованной продукции с учетом всех ценных компонентов, извлечение которых удовлетворяет условию (4.1) в $t$-м году; $3 t$ - общие эксплуатационные затраты на добычу и комплексную переработку сырья в $t$-м году (без учета амортизационных отчислений); $\mathrm{K}_{t}-$ капитальные вложения в $t$-м году; $Э_{t}-$ общий экологический результат комплексной переработки сырья в году $t ; E-$ коэффициент дисконтирования, в современных методиках принимается на основе процента банковской ставки, применительно к разработке месторождений рекомендуется на уровне $10-15 \%$ [82]; $t=0$ - год начала эксплуатации (реализации проекта); $T$ - год завершения инвестиционного проекта (эксплуатации месторождения, общий горизонт расчета не более двадцати лет).

Для сопоставления результатов оценки эффективности извлечения отдельных компонентов традиционным и рекомендуемым методами приведем 
пример комплексного использования свинцово-цинково-баритового сырья (названия компонентов, абсолютный и относительный уровни затрат и цен здесь не играют никакой роли) по схеме простой последовательной селективной флотации. Технико-экономические показатели (табл. 4.1) свидетельствуют о высокой общей экономической эффективности комплексного использования указанного сырья, необходимо определить экономическую эффективность получения каждого из ценных компонентов (концентратов). Для упрощения эффективность будем оценивать по прибыли и коэффициенту эффективности капитальных вложений.

Таблииа 4.1

Исходные данные для оценки эффективности извлечения отдельных компонентов при комплексном использовании сырья (цифры условные)

\begin{tabular}{|c|c|c|c|c|}
\hline \multirow{2}{*}{ Показатель } & \multicolumn{3}{|c|}{ Компонент } & \multirow{2}{*}{ Итого } \\
\hline & свинец & цинк & барит & \\
\hline $\begin{array}{l}\text { Объем добычи и переработки сырья, } \\
\text { тыс. т. }\end{array}$ & - & - & - & 100 \\
\hline Содержание в руде, \% & 4,0 & 2,5 & 15,0 & - \\
\hline $\begin{array}{l}\text { Извлечение в одноименный } \\
\text { концентрат, \% }\end{array}$ & 82 & 70 & 40 & - \\
\hline $\begin{array}{l}\text { Действующая оптовая цена одной } \\
\text { тонны компонента в готовой } \\
\text { продукции, руб. }\end{array}$ & 520 & 330 & 77,8 & - \\
\hline \multicolumn{5}{|l|}{$\begin{array}{l}\text { Стоимость компонентов в готовой } \\
\text { продукции }\end{array}$} \\
\hline тыс. руб. & 1705,6 & 577,5 & 466,8 & 2749,9 \\
\hline$\%$ & 62 & 21 & 17 & 100 \\
\hline \multicolumn{5}{|l|}{ Затраты на производство, тыс. руб. } \\
\hline всего & & & & 2115 \\
\hline косвенные (комплексные) & & & & 1600 \\
\hline прямые & 140 & 175 & 200 & 515 \\
\hline Прибыль предприятия, тыс. руб. & & & & 634,9 \\
\hline \multicolumn{5}{|l|}{ Капиталовложения, тыс. руб. } \\
\hline всего & & & & 2280 \\
\hline косвенные & & & & 1400 \\
\hline прямые & 230 & 260 & 390 & 880 \\
\hline $\begin{array}{l}\text { Коэффициент эффективности } \\
\text { капвложений }\end{array}$ & & & & 0,278 \\
\hline
\end{tabular}

Результаты оценки эффективности извлечения отдельных ценных компонентов по традиционному методу с учетом прямых и косвенных затрат 
представлены в табл. 4.2. При этом прямые затраты отнесены непосредственно на соответствующие выделяемые компоненты, косвенные распределялись пропорционально стоимости извлекаемых компонентов в готовой продукции по оптовым ценам. Выбор конкретного метода распределения косвенных затрат изменяет рентабельность извлечения отдельных компонентов, однако в данном случае принципиального значения не имеет. Главное состоит в том, учитываются ли косвенные затраты, кроме прямых затрат, или нет.

Таблица 4.2

Результаты оценки эффективности извлечения отдельных компонентов по традиционному методу, тыс. руб. (цифры условные)

\begin{tabular}{|c|c|c|c|c|c|c|c|c|}
\hline \multirow{3}{*}{ Показатель } & \multicolumn{4}{|c|}{ I этап оценки } & \multicolumn{3}{|c|}{ II этап оценки } & \multirow{3}{*}{\begin{tabular}{|c}
$\begin{array}{c}\text { III этап } \\
\text { оценки }\end{array}$ \\
$\begin{array}{c}\text { Извлекаемые } \\
\text { компоненты }\end{array}$ \\
свинец
\end{tabular}} \\
\hline & \multicolumn{3}{|c|}{$\begin{array}{c}\text { Извлекаемые } \\
\text { компоненты }\end{array}$} & \multirow[t]{2}{*}{ Итого } & \multicolumn{2}{|c|}{$\begin{array}{c}\text { Извлекаемые } \\
\text { компоненты }\end{array}$} & \multirow[t]{2}{*}{ Итого } & \\
\hline & свинец & цинк & барит & & свинец & цинк & & \\
\hline \multicolumn{9}{|l|}{$\begin{array}{l}\text { Затраты на } \\
\text { производство }\end{array}$} \\
\hline прямые & 140 & 175 & 200 & 515 & 140 & 175 & 315 & 140 \\
\hline косвенные & 992 & 336 & 272 & 1600 & 1195,2 & 404,8 & 1600 & 1600 \\
\hline суммарные & 1132 & 511 & 472 & 2115 & 1335,2 & 579,8 & 1915 & 1740 \\
\hline $\begin{array}{l}\text { Стоимость } \\
\text { продукции }\end{array}$ & 1705,6 & 577,5 & 466,8 & 2749,9 & 1705,6 & 577,5 & 2283,1 & 1705,6 \\
\hline $\begin{array}{l}\text { Прибыль (+), } \\
\text { убыток (-) }\end{array}$ & $+573,6$ & $+66,5$ & $-5,2$ & $+634,9$ & $+370,4$ & $-2,3$ & $+368,1$ & $-34,4$ \\
\hline \multicolumn{9}{|l|}{ Капиталовложения } \\
\hline прямые & 230 & 260 & 390 & 880 & 230 & 260 & 490 & 230 \\
\hline косвенные & 868 & 294 & 238 & 1400 & 1045,8 & 354,2 & 1400 & 1400 \\
\hline суммарные & 1098 & 554 & 628 & 2280 & 1275,8 & 614,2 & 1890 & 1630 \\
\hline $\begin{array}{l}\text { Коэффициент } \\
\text { эффективности } \\
\text { капиталовложений }\end{array}$ & 0,522 & 0,12 & - & 0,278 & 0,290 & - & 0,195 & - \\
\hline
\end{tabular}

Анализ данных табл. 4.2 показывает (I этап оценки), что наряду с высокой эффективностью комплексного использования сырья в целом извлечение барита экономически нецелесообразно. Необходимо отметить, что при отказе от его извлечения предыдущие стадии производства и связанные с ними затраты не меняются.

При распределении тех же косвенных затрат между меньшим количеством извлекаемых компонентов повышается их себестоимость и фондоемкость, что приводит (табл. 4.2, II этап оценки) к снижению эффективности использования сырья в целом (несмотря на то что она остается еще достаточно высокой) и неэкономичности извлечения другого полезного компонента — цинка.

Отказ от извлечения цинка (табл. 4.2, III этап оценки) приводит к неэкономичности как извлечения свинца, так и использования сырья в целом. Очевидная парадоксальность этого вывода, его противоречие с высокими 
исходными технико-экономическими показателями комбинированного комплексного использования сырья в целом (табл. 4.1) свидетельствуют о недостатках, ограниченности и необоснованности традиционного метода оценки.

Таким образом, методом сравнительного моделирования вариантов совокупности монопродуктовых и комбинированного комплексного использования одного и того же месторождения многокомпонентного минерального сырья (рис. 4.1) на конкретном числовым примере подтверждена ограниченность традиционного подхода, приводящая к парадоксальным результатам: отказ от производства убыточного компонента, ведет не к повышению, а к снижению эффективности производства всех других компонентов.

По предложенному же авторами методу оценки сопоставление стоимости компонентов в готовой продукции с прямыми затратами на их выделение, при условии комбинированного комплексного многопродуктового использования сырья, свидетельствует о высокой экономической эффективности организации извлечения каждого из рассматриваемых компонентов в отдельности. Поскольку окупается общая сумма прямых и косвенных затрат, использование рассматриваемого сырья в целом и извлечение каждого из трех его полезных компонентов экономически эффективно, т. е. полностью выполняются все необходимые условия эффективности комбинированного комплексного использования многокомпонентного сырья.

Общеизвестная методика сравнительной оценки вариантов по приростным величинам [78, 82] по своей сущности является производной, частным случаем, всеобщей (исходной) оценки на основе полных затрат и эффектов сравниваемых вариантов. В случае соблюдения принципа методической сопоставимости результат оценки по обоим методам будет одинаковым. По традиционному методу учитываются полные затраты на производство каждого компонента, а эффект лишь частичный — это дополнительно полученная продукция. Однако не учитывается то, что организация получения каждого компонента из многокомпонентного сырья снижает косвенные затраты, относимые на все остальные производимые компоненты, таким образом удешевляя их. Снижение происходит в результате перераспределения косвенных расходов, а общее удешевление продукции по величине соответствует косвенным затратам, которые теперь относятся на компонент (продукт), рассматриваемый в данном контексте как вновь выделяемый (дополнительно ко всем другим).

Таким образом, если при оценке по традиционному методу в составе эффекта дополнительно будет учитываться удешевление продукции, которое количественно равно косвенным затратам, относимым на выделяемый компонент, то в результате получим рекомендуемый метод оценки эффективности извлечения каждого компонента в отдельности, исходя из условия окупаемости только прямых дополнительных затрат, связанных с организацией его производства. Этот вывод в равной степени относится к каждому основному и сопутствующему ценному компоненту минерального сырья.

Применение рекомендуемого метода оценки, по сравнению с традиционным методом, существенно расширяет экономически эффективные границы комплексного использования природного и техногенного минерального сырья. Рекомендуемый подход может применяться при технико-экономических расчетах и обоснованиях комплексного использования природного и техногенного 
многокомпонентного сырья, геолого-экономической оценке МСБ, обосновании параметров кондиций при оконтуривании месторождений и подсчете промышленных запасов отдельных ценных компонентов и комплексного сырья в целом, экономической оценке инвестиционных проектов, выборе рационального варианта освоения месторождений и использования ГПО.

\section{2. Экономический анализ проблемы установления цены на отходы недропользования как вторичное многокомпонентное сырье}

\subsection{1. Сложности ценообразования на отходы в комплексных производствах минерального сырья}

Многостадийный и многооперационный процесс добычи и переработки минерального многокомпонентного сырья характеризуется получением на разных стадиях производства большого числа многокомпонентных разнородных и разнокачественных (по составу, свойствам, назначению и т. п.) готовых основных (профилирующих, целевых), сопутствующих (попутных), промежуточных продуктов (полупродуктов, полуфабрикатов), подлежащих дальнейшей переработке на этом же или на других предприятиях и неиспользуемых в данный момент (отвальных) отходов.

Это обусловливает чрезвычайное усложнение обоснованного определения основных экономических параметров производства каждого из основных, особенно сопутствующих, ценных компонентов (себестоимости, фондоемкости, энергоемкости, цены и др.) в исходном сырье и получаемых продуктах [66], на основе которых вырабатываются оценки и решения о рациональности достигнутого уровня комплексного использования сырья, имеющихся резервах, экономической эффективности производства каждого из ценных составляющих, утилизации отходов и комплексной переработки многокомпонентного сырья в целом. Определяется экономически оптимальный вариант использования сырья, обосновывается стратегия и тактика развития, инвестиционной, технической, ценовой политики конкретного предприятия, отрасли (подотрасли) промышленности, МСК региона и страны в целом.

В рыночных условиях цена на товар зависит одновременно от множества факторов, среди которых в качестве наиболее значимых выделяют [141]: затраты на производство и реализацию продукции; соотношение спроса и предложения; среднеотраслевую рентабельность; качество; эластичность спроса по цене и доходам; конкуренцию на рынке (ценовую и неценовую); государственное регулирование, включая уровень налогов; валютные курсы; учитываются также объемы и условия поставок, удаленность, тарифные и нетарифные ограничения и др.

Все теоретически обоснованные применяемые в современной мировой практике методы ценообразования могут быть объединены в три большие группы [141]: затратные; нормативно-параметрические [149] (или эконометрические); рыночные (или маркетинговые).

Затратные методы ценообразования основаны преимущественно на учете издержек производства и реализации продукции. Нормативно-параметрические (эконометрические) методы базируются на учете потребительских, технико- 
экономических параметров товара. Pыночные (маркетинговые) методы ценообразования предполагают исследование спроса и конкуренции на рынке, т. е. предусматривают использование методов маркетинга.

Теоретически весьма важно при обосновании цены учитывать различные методологические подходы. Прежде всего, в цене должны быть учтены интересы производителя и потребителя. Одни методы (затратные) полнее учитывают интересы производителя, который стремится возместить свои затраты и получить гарантированную прибыль, как правило, без учета, в какой степени такая цена соответствует той пользе, которую обеспечивает эта продукция потребителю. При подходе к цене с позиции полезности для покупателя, как правило, не принимается во внимание, насколько такая цена выгодна или приемлема для конкретного производителя. В практическом плане необходимо, чтобы методика ценообразования максимально полно и объективно отражала как затраты, так и выгоды обеих сторон, иначе достижение взаимоприемлемого уровня цены будет весьма проблематичным, а конкретное сырье (первичное, техногенное) или промпродукт окажется невостребованным, несмотря на возможно высокую экономическую эффективность его использования для народного хозяйства в целом [121].

В качестве одного из конкретных, общественно значимых и в последнее время общеизвестных примеров можно привести осложнения и длительные остановки производства и потребления хибинского нефелинового концентрата из-за разных подходов к обоснованию уровня договорной цены при перезаключении договоров поставки в 2000, 2005 и 2009 гг. Временный разрыв отношений обусловил большие экономические потери как производителя, так и потребителя, их персонала и народного хозяйства в целом, осложнение социально-экономической обстановки в районах расположения контрагентов, а также снижение качества концентрата при возобновлении его производства после вынужденной длительной остановки на период достижения стационарности технологического процесса.

В 2000 г. потребитель нефелинового концентрата - Пикалевское объединение «Глинозем» — объявляло хвосты апатитовой флотации ОАО «Апатит» отходами производства [102], не имеющими стоимости и требовало исключения из отчетной калькуляции его себестоимости непосредственно (прямо) не связанных с производством этого, как, впрочем, и любого другого (апатитового, эгиринового, сфенового), концентрата косвенных затрат на добычу, транспортировку, дробление и измельчение апатитонефелиновой руды, без осуществления которых в принципе невозможно получить никакого готового продукта. Соответственно, на этом основании объединение «Глинозем» настаивало на снижении цены нефелина.

В 2005 г. уже ОАО «СУАЛ», в состав которого к тому времени вошло объединение «Глинозем», требовало снижения цены нефелинового концентрата на том основании, что, по его расчетам, производство глинозема на площадке в г. Пикалево оказывается убыточным. При этом единое, до того уникальное в своем роде, практически безотходное производство по комплексной переработке нефелинового концентрата с выработкой глинозема, содопродуктов и цемента было разделено на три самостоятельных акционерных общества, но представить финансово-экономическую документацию по двум последним подразделениям ОАО «СУАЛ» отказалось. 
Причем высокая рентабельность производства содопродуктов и цемента в рамках ОАО «Глинозем» была общеизвестна и в плановой, и в рыночной экономике. Кстати, щелочные металлы $(\mathrm{Na}, \mathrm{K})$ в нефелиновом концентрате, на основе которых производятся дефицитные высокорентабельные содопродукты, никогда не оплачивались его потребителем (не говоря уже о сырьевых компонентах производимого цемента).

В обоих случаях и в 2000, и в 2005 гг. дело рассматривалось в антимонопольном комитете с привлечением большого количества компетентных в этой предметной области высококвалифицированных специалистов РАН, вузов, производственных объединений и т. д. После долгих разбирательств, восьмимесячной (в 2005 г.) остановки производств документация ОАО «Апатит» и в 2000, и в 2005 гг. признана соответствующей действующим методическим положениям, а претензии потребителя необоснованными. Договоры на поставку были перезаключены на три года по ценам, обоснованным ОАО «Апатит». После истечения срока договора поставки история вновь повторилась, и в 2009 г. для возобновления производства и переработки нефелина потребовалось вмешательство В. В. Путина (бывшего в тот период председателем правительства РФ). В результате ситуация с хибинским нефелином в СМИ теперь именуется как синдром Пикалево. К сожалению, подобные случаи не единичны и не исключены в дальнейшем, поэтому целесообразно рассмотреть сложные теоретические и практические вопросы ценообразования в комплексных производствах более подробно.

По имеющимся опубликованным материалам [141], ценовая политика большинства российских предприятий в настоящее время состоит в том, чтобы покрыть издержки и получить некоторую нормальную прибыль ( $70 \%$ всех предприятий), некоторые ( 9 \%) стараются продать товар как можно дороже. В развитой рыночной экономике Японии затратными методами ценообразования пользуются $36 \%$ от числа опрошенных фирм, маркетинговыми методами - 28 \%, методами, учитывающими конкурентные условия рынка, - 24 \%, методами, ориентированными на движение спроса, $5 \%$, другими методами (в частности, исходя из прямых указаний соответствующих органов и т. д.) - $4 \%$. Перечисленные методы ценообразования достаточно подробно рассмотрены в современной отечественной литературе [141], поэтому в настоящей работе отметим только наиболее важные аспекты преимущественно применительно к специфике комплексных производств, практически не отражаемые в публикациях.

Анализ мнений различных авторов по методологическим проблемам экономики комплексных производств свидетельствует о необходимости совершенствования понятийного аппарата, поскольку различные трактовки одних и тех же понятий применительно к многономенклатурным производствам с комплексной переработкой минерального сырья приводят к неоднозначным, противоречивым выводам, решениям, теоретическим построениям, методам количественной оценки уровня и эффективности комплексного использования сырья, вплоть до фактического отрицания возможности научного подхода к определению экономических параметров [66] и оценки экономической эффективности производства каждого из ценных составляющих многокомпонентного полезного ископаемого. 
Наиболее существенные проблемы ценообразования в комплексных производствах связаны с неоднозначностью подходов к определению таких взаимосвязанных понятий, как: основная и попутная продукиия; перечень ценных компонентов в сырье и продуктах переработки, подлежащих учету, извлечению, соответственно, оплате потребителями; промежуточные продукты и отходы производства; прямые и косвенные затраты на производство отдельных продуктов (компонентов).

Выделение основной и попутной продукции основывается на узкоотраслевом, или технократическом, подходе, не имеет строго научного обоснования, исключает возможность объективной дифференцированной экономической оценки всех производимых продуктов, поскольку себестоимость попутной продукции, как правило, не определяется, а основной, соответственно, искажается [121]. С экономической точки зрения все ценные компоненты минерального сырья являются равнозначными.

В соответствии с данными геохимии в любой горной породе присутствуют в разных количествах практически все известные химические элементы, а научно-технический прогресс позволяет эффективно извлекать полезные компоненты при все более низком их содержании в исходном сырье. Перечень фактически извлекаемых ценных компонентов из минерального сырья с течением времени возрастает, особенно на предприятиях цветной металлургии. Соответственно, все полезные компоненты, содержащиеся в сырье (продуктах последующей его комплексной переработки) в количествах и формах, приемлемых (достаточных) для экономически оправданного извлечения при современном уровне науки и техники, подлежат учету, калькулированию и оплате потребителями. Причем при комплексной переработке сырья достаточным условием эффективности является окупаемость только прямых непосредственных затрат, неизбежно связанных с организацией производства конкретного компонента (без учета какой-либо части косвенных расходов), его стоимостью в готовой продукции по действующим рыночным ценам [121]. В то же время обоснование цены реализации любого продукта комплексной переработки сырья на предстоящий плановый период в общем случае должно исходить из полной его себестоимости (суммы прямых и косвенных затрат производства) с учетом всех ценных составляющих при содержаниях каждого выше его предельного (браковочного), прогнозируемого состояния рынка (соотношения спроса и предложения) этого продукта и его ценных составляющих [121].

\subsection{2. Проблема согласования цен на товарные концентраты из многокомпонентного техногенного сырья}

Ранее отмечалось, что известно четыре методологических подхода к исследованию КИМС, включая обоснование цен вырабатываемых видов продукции: дискриминационный, бухгалтерский, технократический, нигилистский [66, 121].

Но наиболее правильным в данном теоретически весьма сложном случае является системный междисциплинарный подход к исследованию взаимосвязанных проблем комплексного использования многокомпонентного природного, техногенного, нетрадиционного, вторичного (металлического и 
неметаллического лома) минерального сырья, разнообразных ГПО, всей совокупности ресурсов недр, также, впрочем, как и растительного, животного, биологического и других видов ресурсов, содержащих одновременно несколько ценных составляющих. Применительно к минеральному сырью необходим учет геологических, технологических, экономических, экологических, природоохранных и социальных аспектов по всему циклу изъятия, переработки и использования вещества природы по принципу «от земли до земли».

В этой связи необходимо подчеркнуть, что отходами разных стадий комплексного использования сырья являются только не востребованные в период образования (отвальные) продукты, а все, что находит полезное применение в рамках предприятия или реализуется на сторону для последующей переработки или непосредственного использования, является промежуточным или готовым продуктом, подлежащим текущей стоимостной оценке (в соответствии с потребительной стоимостью) и оплате сторонними организациями [66].

Таким образом, совершенно очевидно, что рациональная методика ценообразования должна обеспечивать обоснованность дифференцированных оценок каждого из используемых компонентов в исходном комплексном сырье, разнообразных промежуточных продуктах его последующей переработки, включая утилизируемые отходы различных стадий производства, и всего ассортимента готовой конечной продукции взаимосвязанных предприятий-контрагентов в рамках системы отраслей МСК с учетом фактических издержек на производство отдельных ценных компонентов в условиях комплексных производств и конъюнктуры внутреннего и мирового сырьевых рынков.

Значимость и сложность проблемы существенно возрастают при определении и согласовании цен между производителями и фактическими или потенциальными потребителями товарных концентратов (в подавляющем большинстве случаев имеющих комплексный многокомпонентный состав). При этом в теоретическом и практическом планах потребителями не принимается во внимание объективный характер ограниченности и невоспроизводимости минерально-сырьевых ресурсов, снижение в долгосрочном плане содержания ценных компонентов в добываемом сырье, усложнение его качества, горно-геологических и горнотехнических условий горных работ, существенный рост издержек в связи с неизбежным понижением (и постоянным перемещением в пространстве) горных работ и затрат на обогащение более бедных и, как правило, сложных по вещественному составу руд с получением стандартных или даже более качественных концентратов. Научно-технический прогресс в горно-обогатительном производстве, как показывает практика, не в состоянии компенсировать отмеченное усложнение производства и удорожание концентратов. Перерабатывающие же химикометаллургические предприятия имеют дело со все более качественными или по крайней мере со стабильными по качеству концентратами и могут в полной мере пожинать плоды научно-технического прогресса. Иными словами, в долгосрочном плане при государственном регулировании цен как в плановой, так и в рыночной системах хозяйствования в отношении минеральных концентратов с учетом приоритета народнохозяйственных интересов должна соблюдаться тенденция изменения цен в пользу горно-обогатительного производства. Однако на практике преобладает прямо противоположная 
тенденция, поскольку объективно добывающие производства являются центрами затрат, а перерабатывающие (финишные) производства - центрами прибыли, имеющими в силу этого возможности диктовать свои условия хозяйственных взаимоотношений.

Особенно сложные проблемы и острые (порой непримиримые) споры между контрагентами (производителями и переработчиками) возникают при стоимостной оценке и согласовании цен на разного рода полуфабрикаты, промежуточные продукты (шламы, шлаки, стоки, пыли, возгоны, хвосты обогащения и другие текущие и накопленные отходы разных стадий горнопромышленного производства). Наиболее ярко такую ситуацию можно наблюдать при организации переработки (утилизации) накопленных (лежалых) отходов горнопромышленного комплекса.

По мере освоения технологии утилизации отходов получаемая на их основе продукция, как правило, проходит разные стадии: от суррогатного, но дешевого заменителя продукции, получаемой по другой технологии или из другого сырья, до высококачественной, даже высококонкурентной, продукции, имеющей стратегическое значение. Поэтому первоначально бросовые (не имеющие стоимости) отходы становятся высокоценным сырьем и должны получать адекватную стоимостную оценку.

С точки зрения стоимостной оценки безвозвратные потери и неиспользуемые отходы, естественно, не подлежат оценке, поскольку в момент образования они не имеют потребительной стоимости, следовательно, не могут иметь и меновой. С точки зрения теории полезности «бесполезная для потребителей вещь не имеет цены» [149]. С момента же начала промышленной переработки либо реализации на сторону отходы переходят в категорию используемых, пополняют номенклатуру сопряженных продуктов комплексной переработки минерального сырья и должны оцениваться и оплачиваться на основе тех же принципов. Эквивалентные по потребительной стоимости количества разных продуктов теоретически имеют одинаковую меновую стоимость. То есть при стоимостной оценке отходов производства (в том числе и горнопромышленных) целесообразно использовать параметрические методы ценообразования. Поскольку при использовании комплексных месторождений отходы являются также многокомпонентными, в общем случае необходимо использовать агрегатную модель ценообразования [121] для ГПО, учитывающую целесообразность утилизации и оценки всех их ценных составляющих, содержания которых превышают предельные (браковочные) [91, 92]. Браковочные содержания ценных компонентов определяются из условия окупаемости прямых неизбежных затрат, необходимых для организации извлечения компонентов, окупаемых за счет стоимости дополнительно получаемой продукции.

Отсюда видно, что расширительное толкование понятия отходов, стремление потенциальных потребителей объявить отходы любой стадии переработки минерального сырья бесплатными, общедоступными не имеют под собой объективной экономической основы. 


\subsection{3. Принципы ценообразования и оценки экономической эффективности утилизации отходов добычи и переработки рудного сырья}

Отмеченный выше качественный переход ГПО из категории бросовых в период их образования в категорию потенциально полезных, а затем фактически полезных после разработки эффективной технологии их утилизации на практике осложняет и зачастую препятствует производительному их использованию. Это обусловлено тем, что предприятия - владельцы отходов желают получить достаточно ощутимую дополнительную прибыль, но любая, даже чисто символическая, цена вчера еще никому не нужных отходов психологически отталкивает возможных потребителей, а при определенной величине вообще исключает возможность получения прибыли потенциальными потребителями.

Для эффективного решения проблемы рекомендуется процесс формирования взаимоприемлемой для контрагентов цены на договорной основе с использованием процедур сближения, согласования (уторговывания) позиций. В частности, оценка экономической эффективности утилизации отходов (для народного хозяйства в целом) должна осуществляться при нулевой стоимости отходов, а их окончательная договорная цена должна определяться из согласованного распределения между участниками общего экономического эффекта конкретного проекта утилизации отходов, на основе оценки вклада каждого участника в реализацию совместного проекта [121].

В качестве необходимых принципов ценообразования и оценки экономической эффективности утилизации отходов, подлежащих дальнейшей разработке и учету, на практике можно отметить следующие: 1) в целях стимулирования утилизации отходов их оценка на практике несколько занижается по сравнению с эквивалентным количеством первичного сырья; 2) необходимо в отдельный вид выделить экологически опасные отходы, обращение с которыми требует дополнительных расходов, и организациям, согласным принять экологически опасные отходы на переработку, хранение, обезвреживание, захоронение и т. д., необходимо доплачивать теоретически (объективно) в пределах прогнозируемых затрат на обращение с ними в рамках собственного предприятия, т. е. экологически опасные отходы имеют отрицательную цену для предприятия (ярким примером являются радиоактивные отходы); таким образом, при стоимостной оценке конкретного вида отходов необходимо учитывать соответствующую отрицательную составляющую; 3) использование отходов производства (твердых, жидких, газообразных) в рамках предприятия либо за его пределами в качестве вторичного сырья для производства аналогичной или принципиально другой продукции (иной отраслевой принадлежности или сферы потребления), строительных материалов и других нужд позволяет высвободить часть земельных угодий, используемых под хвостохранилища, шлаковые, вскрышные и другие отвалы, сократить затраты на строительство и содержание последних и имеет большое социальное значение из-за уменьшения или предотвращения загрязнения ОС.

Целесообразным является государственное регулирование и экономическая поддержка (субсидирование) научно-исследовательских работ и инвестиционных проектов по применению ГПО в разных направлениях, в первую очередь, в строительстве как наиболее масштабном и экологически значимом. Необходимо также исследовать целесообразность применения административных 
запретительных мер на местном уровне по разработке месторождений общераспространенных полезных ископаемых в регионах, где соответствующая потребность может быть удовлетворена за счет использования имеющихся ГПО без существенного удорожания работ.

Следует отметить [121], что в комплексных производствах недропользователем могут использоваться все перечисленные выше методы ценообразования. Однако специфические особенности комплексного использования сырья, характеризующиеся чрезвычайно обширной номенклатурой разнообразных, разнокачественных продуктов сложного многокомпонентного состава, разной степени готовности и чистоты, обусловливают широкое применение метода нормативно-параметрического ценообразования для дифференциация базовых цен в зависимости от потребительских свойств и технико-экономических параметров продукции. При использовании этого метода в качестве базового продукта (соответственно, исходной базовой цены) для конкретного ценного компонента целесообразно принимать наиболее типичный, представительный, как правило, биржевой вид товара, характерный для мирового рынка либо соответствующего регионального или внутреннего рынка для ценных компонентов, не являющихся предметом экспортно-импортных операций. В частности, в качестве известного, общепризнанного центра мировой торговли, во многом определяющего уровень и динамику цен свободного рынка, можно назвать Лондонскую биржу металлов. Например, цены на алюминийсодержащие товары (глинозем, бокситы, нефелины и т. д.) во взаиморасчетах производителей и потребителей «привязаны» (составляют определенный процент, согласованный в договорах поставки на обусловленный период) к текущей цене металлического алюминия на ЛБМ.

Наряду с необходимостью установления дифференцированных цен на отдельные ценные компоненты в разнообразных продуктах, широкое распространение в комплексных производствах получил агрегатный метод ценообразования [121] на продукт в целом как суммарная цена всех содержащихся в нем промышленно значимых полезных составляющих, т. е. при содержаниях извлекаемых форм выше их предельных (браковочных) [92].

\section{3. Методические подходы к покомпонентному обособлению прямых затрат при комбинированной переработке многокомпонентного минерального сырья}

\subsection{1. Подходы к покомпонентному разделению прямых и косвенных затрат при комплексном использовании минерального сырья}

В многостадийных, многооперационных технологических процессах комбинированной комплексной переработки сырья с выделением различными методами отдельных ценных составляющих в обособленные продукты и их доводки до определенной степени чистоты принципиально важным является покомпонентная идентификация прямых и косвенных затрат. Прямые затраты, относимые на себестоимость конкретного ценного компонента, непосредственно связаны и неизбежно возникают при организации производства только данного компонента. Косвенные затраты обеспечивают производство одновременно двух и более или всех вырабатываемых из комплексного сырья ценных компонентов, 
формируя их себестоимость в соответствии с выбранной и экономически обоснованной базой распределения.

Как показывает анализ, существуют различные точки зрения по этому вопросу. Например, в ряде работ утверждается, что прямыми являются затраты на всех стадиях и операциях производства, начиная с которых разворачивается целенаправленная деятельность по извлечению конкретного ценного компонента [109]. Весь сложный многостадийный и многооперационный процесс комбинированного комплексного использования сырья представлялся как совокупность (комбинация) двух типов элементарных производственных процессов: процессы с одновременным выделением из сырья нескольких (разнородных) продуктов (полезных компонентов) или процессы разделения сырья; процессы с последовательным выделением отдельных продуктов (компонентов) в обособленных циклах (операциях), разделенных между собой во времени и пространстве. Применительно к первому типу процесса передельные затраты (добавленную стоимость) предлагалось распределять между всеми выделяемыми продуктами (компонентами), во втором случае полностью относить только на выделяемый продукт (компонент).

В работе [51] разделительные процессы трактуются более широко, чем описано выше, например, процесс флотации апатита из апатитонефелиновой руды рассматривается как разделительный процесс, в результате которого получаются два полуфабриката — апатитовый и нефелиновый. Соответственно, затраты разделительного процесса распределяются между производствами апатитового и нефелинового концентратов. Затраты же на доводку каждого из полуфабрикатов до соответствующего товарного концентрата стандартного качества, осуществляемую в обособленных циклах, рассматриваются как прямые и относятся на готовые продукты прямым счетом, что представляется удачным и теоретически обоснованным решением, определенным творческим вкладом в разрешение сложной проблемы распределения затрат между продуктами комплексной переработки многокомпонентного сырья.

Изложенный подход требует более детального рассмотрения, четкого разграничения и диагностики прямых и косвенных затрат, а также определения конкретного перечня ценных компонентов, между которыми необходимо распределять косвенные затраты каждого разделительного процесса (технологической операции).

\subsection{2. Диагностика прямых покомпонентных затрат при технологических операциях комплексной переработки минерального сырья}

Головные разделительные процессы с одновременным либо последовательным выделением из многокомпонентного сырья нескольких продуктов, которые чаще всего можно квалифицировать как полуфабрикаты (полупродукты, черновые концентраты), подлежащие дальнейшей доработке, доводке до определенных кондиций (перечистные, доводочные операции), - это технологические операции, необходимые для получения каждого из ценных компонентов, связанные с ними затраты относятся к общим, косвенным.

Извлечение из многокомпонентного сырья (руды, концентрата, полуфабриката, полупродукта) одного из компонентов сопровождается повышением содержания в остатке сырья (отходах процесса выделения 
первого компонента) других ценных компонентов. Это, как правило, ведет к упрощению и удешевлению операций их последующего извлечения, т. е. повышению промышленной ценности и стоимости.

В зависимости от физико-химических свойств извлекаемых компонентов разделительный процесс (например, процесс флотационного обогащения - разделения минералов различной флотоактивности) может быть организован по принципу как прямой, так и обратной флотации: в пенный и камерный продукты может направляться любой из разделяемых компонентов. Для практической реализации выбирается тот вариант флотации, который является экономически более эффективным. Аналогично процесс гравитационного разделения золота и кварцевого песка может рассматриваться как процесс выделения концентрата тяжелого полезного компонента и с такой же результативностью как процесс выделения концентрата более легкого компонента. Эти операции эквивалентны для производства того и другого сопряженного продукта. Иными словами, сущность разделительных процессов с точки зрения распределения экономических издержек на их осуществление между полезно используемыми компонентами сырья не меняется при изменении количества или порядкового номера выделяемых компонентов.

В качестве наглядных примеров использования разных признаков при разделении ценных компонентов в разделительных процессах различных подотраслей МСК можно привести следующие. Магнитная сепарация руды в ОАО «Ковдорский ГОК» означает не только производство железосодержащего чернового концентрата, но и одновременно получение немагнитного апатитсодержащего полуфабриката, поскольку в хвостах сепарации существенно повышается содержание апатита и резко снижается содержание железа. С позиции принципа рационального поведения необходимо поддерживать такой режим разделения, который обеспечивает достижение максимально полного разделения магнитных и немагнитных минералов и получение максимально чистых железного и апатитового продуктов (концентратов) одновременно. Аналогично процесс коллективной флотации на Белоусовской обогатительной фабрике (Республика Казахстан), перерабатывающей барит-полиметаллическую руду, является процессом флотационного разделения сульфидов свинца, цинка и меди (выделяемых в коллективный концентрат этих металлов - пенный продукт) и несульфидного минерала - барита (сернокислого бария), выделяемого в виде камерного продукта. Каждый из этих полуфабрикатов затем перечищается, доводится до определенных параметров, а коллективный сульфидный концентрат, кроме того, подвергается селекции, в результате из него последовательно выделяются свинцовый, цинковый и медный концентраты, каждый из которых вначале выделяется в виде чернового концентрата и затем подвергается перечистке. При этом в зависимости от особенностей вещественного состава руды и производственной программы (рыночного спроса) каждый из производимых концентратов может иметь несколько модификаций, сортов, марок.

Следует подчеркнуть, что разделительный процесс и соответствующие ему затраты необходимы для производства по крайней мере двух полезных компонентов (продуктов). В случае прекращения производства какого-либо из продуктов (по причине существенного снижения рыночного спроса, неэффективности, неконкурентоспособности и т. д.) разделительный процесс в большинстве случаев будет осуществляться в том же режиме. Однако 
связанные с ним затраты будут распределяться между меньшим количеством полезных компонентов либо относиться на один из них, если производство других признается нецелесообразным и прекращается ${ }^{84}$. При прекращении производства какого-либо компонента исключаются лишь доводочные (перечистные) операции и соответствующие им прямые затраты на производство конкретного компонента (продукта).

Например, при использовании апатитонефелиновых руд процесс разделения апатита и нефелина - апатитовая флотация - осуществляется и при переработке той части руды, из которой нефелин не вырабатывается по причине ограниченного спроса. В этом случае нефелиновый полуфабрикат без какой-либо доводки сбрасывается в хвостохранилище, а все расходы разделительного процесса (как и всех предыдущих подготовительных операций производства) целиком относятся на апатит.

Исходя из изложенного, основным диагностическим признаком вычленения (обособления) прямых затрат, непосредственно и неизбежно связанных с получением из многокомпонентного сырья каждого ценного компонента (продукта), является выделение операций по доводке полуфабрикатов разделительных процессов до соответствующих стандартных готовых товарных продуктов. В качестве дополнительного диагностического признака прямых затрат следует использовать результаты анализа перечня технологических операций многопродуктовой переработки сырья, которые вводятся или исключаются при организации (прекращении) производства конкретного продукта (ценного компонента). Затраты на осуществление выявленных таким образом операций и процессов, включая операции сгущения, фильтрации, сушки, складирования, затаривания, погрузки, отправки и реализации каждого продукта в отдельности, и являются прямыми для анализируемого продукта (компонента). Кроме того, с введением принципов платного природопользования к прямым затратам необходимо относить соответствующие ресурсные платежи, дифференцируемые по отдельным ценным компонентам, а при экспорте продукта - прямые таможенные платежи и сборы по конкретному товарному продукту (компоненту).

Аналогично затраты по всем остальным технологическим операциям, необходимым для производства двух и более ценных компонентов, являются косвенными, подлежащими распределению между соответствующим перечнем извлекаемых компонентов. Процедуру анализа технологической схемы и определения конкретного перечня извлекаемых компонентов, между которыми необходимо распределять косвенные расходы, можно существенно упростить, если начинать его только с самого первого (головного) разделительного процесса, поскольку все предшествующие операции добычи, транспортировки сырья на перерабатывающую установку, дробление, измельчение, дезинтеграции и т. п. являются априори обязательными для любого ценного компонента конкретного исходного многокомпонентного сырья.

84 При снижении выпуска, тем более прекращении производства отдельных компонентов, рентабельность использования многокомпонентного сырья снижается и может оказаться отрицательной. 


\subsection{3. Необходимость дифференцированного учета затрат по отдельным процессам и операциям переработки многокомпонентного сырья}

В зависимости от конкретных условий разрабатываемого месторождения (отдельной залежи, геологического блока и т. п.) первичное разделение минеральных комплексов может осуществляться уже на стадии извлечения полезных ископаемых из недр при осуществлении селективной добычи отдельных сортов или слоев полезного ископаемого. Поэтому целесообразно уже на стадии разработки технологии комбинированного комплексного использования многокомпонентного сырья или проектирования соответствующих промышленных объектов составлять подробный, исчерпывающий перечень последовательных стадий и операций добычных, подготовительных, разделительных и доводочных процессов с перечнем конкретных используемых ценных компонентов, между которыми распределяются (или полностью относятся на один из них) затраты этих операций.

Основной принцип формирования дифференцированного по операциям перечня ценных компонентов состоит в определении необходимости (либо возможности исключения) каждой операции общей технологической схемы комбинированной переработки многокомпонентного сырья в случае производства из данного сырья только рассматриваемого компонента. В результате по каждой операции будет составлен перечень компонентов, производство которых без данной операции принципиально невозможно. Если по конкретной операции перечень будет состоять из единственного компонента, затраты по этой операции являются прямыми для данного компонента и относятся полностью на него прямым счетом. При наличии в перечне двух и более компонентов, в общем случае $n$-компонентов, затраты по соответствующей операции являются косвенными (комплексными) и должны распределяться между всеми $n$-компонентами пропорционально возрастанию стоимости каждого из них в результате осуществления данной операции (либо другим более простым, но и менее точным частным методом).

При изменении технологии, перечня технологических операций, извлекаемых полезных компонентов и т. п. процедуру дифференциации прямых и косвенных затрат необходимо повторить и скорректировать применительно к новой ситуации. Необходимым условием для этого является организация дифференцированного учета затрат по отдельным процессам и операциям переработки многокомпонентного сырья с таким расчетом, чтобы выделить и количественно определить прямые затраты на производство каждого конечного товарного продукта. Полученные параметры ценных компонентов в последующем используются в различных технико-экономических расчетах и обоснованиях, в планировании на предприятиях-недропользователях при комбинированной комплексной переработке минерального сырья. Пока такой учет не налажен, определение прямых затрат на действующих предприятиях может быть выполнено расчетным путем по методике, суть которой изложена в работе [69].

Целесообразность внедрения пооперационного учета затрат для углубления экономического анализа и более полного выявления резервов производства отмечают многие исследователи [62]. Вместе с тем вряд ли целесообразна и практически возможна такая детализированная система учета и отчетности, которая могла бы ежемесячно предоставлять исчерпывающую 
информацию об издержках для всех возможных направлений исследований. Более детальные данные о распределении затрат требуются лишь периодически. Методически распределение производственных затрат по операциям технологического процесса переработки сырья не сложно ввиду их достаточно четкой пространственной обособленности. Основано оно на сборе и обработке первичной технической и бухгалтерской (учетной) документации предприятий и широко применяется в исследовательской и практической работе [69].

\section{4. Экономическое обоснование методики расчета параметров кондиций для оконтуривания и подсчета промышленных запасов многокомпонентного природного и техногенного сырья}

\subsection{1. Недостатки существующих подходов коценке попутных компонентов многокомпонентного сырья при обосновании кондиций}

Степень рациональности использования как природного, так и техногенного минерального сырья во многом зависит от обоснованности применяемой методологии геологического изучения и геолого-экономической оценки разведанных ресурсов, в частности, при экономическом обосновании основных параметров кондиций с целью правильного оконтуривания и подсчета промышленных (рентабельных для эксплуатации) запасов месторождения, оценки эффективности инвестиционных проектов их разработки. Изучение, геологоэкономическая оценка многокомпонентного минерального сырья предполагает необходимость дифференцированной оценки эффективности использования и учета в балансовых запасах каждого из ценных компонентов в отдельности [92]. Это представляет собой сложную для решения в теории и на практике многофакторную и многокритериальную задачу, отдельные аспекты которой трактуются и решаются различными исследователями и специалистами по-разному, зачастую на интуитивном уровне.

Порядок, принципы, методология и процедура обоснования, экспертизы, согласования и утверждения параметров кондиций регламентируются нормативнометодической документацией ГКЗ РФ, которая периодически перерабатывается и уточняется по мере совершенствования технологий и развития научнометодического обеспечения добычи и переработки минерального сырья.

В научном плане особенностям комплексного изучения месторождений и подсчету запасов попутных полезных ископаемых и компонентов значительное внимание уделяется с начала 1970-х гг. В настоящее время применительно к оценке попутных компонентов многокомпонентного минерального сырья нормативно-методическая документация ГКЗ естественным образом использует в основном традиционные подходы и методики, не свободные от существенных недостатков и противоречий. Это препятствуют повышению эффективности комплексного использования многокомпонентного минерального сырья, что требует обновления существующей нормативно-методической базы. Одним из шагов к решению указанной проблемы можно считать корректировку методических указаний ГКЗ в 2007 г. [82]. Обновленная редакция методических указаний ГКЗ рекомендует, хотя и не вполне последовательно, как будет показано далее, 
некоторые элементы нового подхода при обосновании отдельных параметров кондиций применительно к попутным компонентам.

В качестве наиболее значимого показателя при обосновании параметров кондиций на любое многокомпонентное минеральное сырье рассчитывается минимально-промышленное содержание основного (в Методических рекомендациях от 5 июня 2007 г. № 37-p [82] — «главного основного», который имеет наиболее высокий удельный вес в товарной продукции предприятия) компонента. При этом стоимость извлекаемых попутных компонентов снимается с затрат на производство основного или в большинстве случаев с суммы основных полезных компонентов, приведенных к главному основному. Однако вопрос о круге полезных компонентов, которые включаются в расчет содержания условного компонента по тому или иному подсчетному блоку, месторождению решается субъективно, в связи с тем что экономическая целесообразность получения отдельных компонентов при этом не выявляется. Более того, минимальное содержание попутных компонентов при обосновании кондиций и подсчете запасов, как правило, не устанавливается либо рекомендуется принимать его близким к их содержанию в отходах обогащения или металлургического (химического) передела [82].

К настоящему времени в достаточной мере приемлемого научного определения понятия попутной продукции, попутного компонента в литературе не имеется. Показательно, например, что на практике в полиметаллическом сырье три ценных компонента (свинец, цинк и медь) неизменно относятся к основным, а все остальные реально извлекаемые (благородные, редкие и рассеянные металлы, сера, барит и т. д.) относятся к попутным компонентам, независимо от величины их содержаний в исходном сырье и удельного веса в стоимости товарной продукции горнопромышленного предприятия, что явно не может считаться научно обоснованным!

Наиболее развернутая характеристика понятия попутных ископаемых и компонентов содержится в нормативно-методических материалах ГКЗ РФ [23, 24, $79,82,126]$. В частности, в переработанном, последнем по времени утверждения и публикации, варианте Методических рекомендаций по комплексному изучению месторождений и подсчету запасов попутных полезных ископаемых и компонентов [82, с. 3-6] в следующей редакции (цитата из документа здесь и далее выделена авторами настоящей монографии курсивом): «K попутнылм полезнылм ископаемьым относятся минеральные комплексы (горные породы, руды, подземные воды, рассолы), не имеющие самостоятельного промышленного значения, но добыча которых при разработке основного полезного ископаемого может быть экономически челесообразной.

$K$ попутным компонентам относятся заключенные в полезных ископаемых минералы, металль и другие химические элементы и их соединения, которые, как правило, не имеют определяющего значения для промышленной оченки месторождений, но при переработке полезных ископаемых могут быть рентабельно извлечены и использованы.

Вместе с тем, понятие «попутный компонент» достаточно условное и зависит от неравномерно меняющейся во времени рыночной конъюнктуры разных полезных ископаемых", что особенно характерно для многих месторождений редких и иветных металлов. В связи с этим необходимо определить понятие «основной полезный компонент». 
K основным полезным компонентам относятся заключенные 6 полезных ископаемых металль и другие химические элементы, их соединения или минераль, определяющие промышленную значимость месторождения, m. е. возможность его рентабельной отработки без учета стоимости прочих (nопутных) компонентов. Это могут быть компоненты, участвующие в оконтуривании рудных тел индивидуально или через коэффициенть приведения к условному компоненту, а также компоненты, не учтенные при определении контуров рудных тел, но без реализации которых разработка месторождения экономически не эффективна (их доля в суммарной стоимости товарной продукичи обычно превылиает $10 \%$ \%).

Попутные полезные ископаемые и компоненты в зависимости от форм нахождения, связи с основными для данного месторождения полезными ископаемыми и компонентами $u$ с учетом требований, предъявляемых промышленностью к условиям их разработки (извлечения), разделяются на три гpynnbl.

\footnotetext{
* Имеются примеры, когда компонентыл, учтенные при разведке месторождений как попутные, в дальнейшем, при их эксплуатации, переходили в основные. Так, Ковдорское месторождение вначале разрабатывалось как железорудное, но в настоящее время в стоимости товарной продукции доля железорудного (магнетитового) концентрата составляет лишь около трети, а более 60 \% приходится на апатитовый и бадделеитовый концентраты.
}

K I группе относятся попутные (сопутствующие) полезные ископаемые, образующие самостоятельные пласты, залежи или рудные тела в породах, вмещуающих основные полезные ископаемые...

$K$ этой же группе относятся вскрышные породы, по составу $u$ свойствам пригодные для производства строительных материалов ... или для других изелей, а также торф и почвенно-растительный слой...

Ко II группе относятся попутные компоненты (минераль), не образуюшие самостоятельных залежей, но которые при обогащении могут быть выделены в самостоятельные концентраты или промпродукты в количествах, допускающих их последующее извлечение на экономически рациональной основе.

$K$ этой же группе относятся попутные компоненты, заключенные в нефти и горючих газах, выделяемые при добыче (сепарации) в самостоятельные продукты, а также метан, содержашийся в угольных пластах...

K III группе относятся различного рода примеси в минералах основных $и$ попутных компонентов (изоморфные, механические, микровключения собственных минералов и др.), а также органические, металлические или металлоорганические соединения в углях и углистых породах. Преобладаюшую часть попутных компонентов III группы составляют так называемые рассеянные элементы, широко распространенные в различных твердых полезных ископаемых при весьма низких содержаниях. $K$ этой же группе относятся примеси в рудных минералах золота, серебра, МПГ, тантала, редких земель, стронщия, молибдена и др. При обогащении полезных ископаемых эти компоненты накапливаются 6 концентратах основных компонентов, а при переработке концентратов или непосредственном использовании полезных ископаемых в металлургическом, 
химическом, энергетическом и других производствах - концентрируются $в$ товарных продуктах или отходах.

K этой же группе относятся попутные компоненты, присутствуюшие в нефти и газе и выделяемые лишь при их переработке, а также заключенные в подземных минерализованных водах и рассолах...

Изучение попутных полезных ископаемых проводится в границах разведки основных полезных ископаемых...»

\subsection{2. Критический анализ положений о попутных компонентах в нормативно-методических документах Государственной комиссии по запасам полезных ископаемых}

По существу приведенных выше положений нового переработанного нормативно-методического документа ГКЗ (как и к ранее изданным), являющегося обязательным к применению при любых геологоразведочных работах, можно высказать ряд существенных замечаний, сомнений в научной обоснованности отдельных понятий, принципов, рекомендаций, иногда допускающих различные толкования, следовательно, неоднозначность решения конкретных вопросов.

1. Если понятие «попутный компонент» достаточно условное, то и все последующие взаимосвязанные с ним понятия (в частности, «основной», «основные», «главный компоненты»), рассуждения, рекомендации также являются условными. Зачем сложную проблему дополнительно усложнять условными понятиями?

2. Не ясно, как быть в тех случаях, когда рентабельность отработки месторождения обеспечивается только в случае учета стоимости прочих (nоnутных) компонентов? Это не промышленное месторождение? Или всетаки промышленное, поскольку рентабельная отработка обеспечивается?

В предложенном ГКЗ определении понятия попутных компонентов остается неясным, как быть в тех случаях, довольно многочисленных на практике, когда каждый попутный компонент сырья в отдельности экономически менее значим, чем основной, при этом в совокупности попутные компоненты имеют «определяющее значение для промышленной оценки месторождения», т. е. без их учета и использования разработка оказывается нерентабельной?

3. Если теоретически предположить, что в полезном ископаемом (например, в полиметаллической руде) содержится 11-15 ценных компонентов с примерно равной извлекаемой ценностью, но менее $10 \%$ от итога по каждому из них, то в такой руде нет основного компонента? Все попутные?

4. Если доля каждого из трех, четырех компонентов сырья существенно превышает 10 \% общей извлекаемой ценности, но себестоимость одного (или более) из них выше рыночной цены, такой компонент является основным и подлежит учету в промышленных запасах месторождения?

5. Из анализа цитируемой части документа логически следует, что основное полезное ископаемое и компонент обязательно должны быть представлены на конкретном месторождении самостоятельным минералом и пластом, залежью или рудным телом. Но если максимальную долю в извлекаемой ценности будет иметь редкий или редкоземельный элемент, не образующий собственных минералов, он все равно будет считаться попутным? 
6. Форма нахождения каждого конкретного ценного компонента в горной массе месторождения в широком смысле (включая, кроме промышленной залежи, весь комплекс покрывающих и часть вмещающих пород) и взаимосвязанный с ней технологический принцип последующего выделения компонентов в самостоятельные готовые конечные продукты принята в качестве основы группировки попутных полезных ископаемых и компонентов. Безусловно, это обстоятельство является весьма важным и необходимым для геологоразведочных работ и рационального использования ресурсов месторождения. Но заявленный принцип не облегчает решения сложной проблемы определения себестоимости каждого из вырабатываемых компонентов (продуктов) и дифференцированной оценки экономической эффективности производства каждого их них в отдельности, обоснования рационального перечня полезных компонентов, подлежащих извлечению и учету в промышленных запасах.

7. Зачастую и основные компоненты представлены в сырье как самостоятельными минералами (извлекаемыми либо не извлекаемыми по имеющимся технологиям), так и различными неструктурными механическими или изоморфными примесями в рудных и нерудных минералах. То есть необходимость изучения форм нахождения в сырье должна распространяться на все без исключения как полезно используемые, так и удаляемые в отходы компоненты, особенно экологически опасные. Кроме того, не решается проблема дифференцированной оценки экономической эффективности извлечения и использования каждого из основных полезных компонентов в тех случаях, когда их в перерабатываемом сырье больше одного, например, медь и никель в медно-никелевом; медь и цинк в медно-цинковом; медь, свинец и цинк в полиметаллическом сырье. Предлагается лишь выделять условный основной или главный [82] из основных компонентов, который имеет наибольший удельный вес в товарной продукции. Но содержания ценных компонентов в пределах месторождения (залежи, выемочного блока) в большинстве случаев варьируют в широких диапазонах, а уровень извлечения отдельных компонентов при переработке сырья может существенно меняться, особенно при изменении технологии, так что удельный вес основных компонентов в стоимости товарной продукции не является постоянным.

8. Попутные компоненты в методических рекомендациях [23, 24, 78, $79,82,126]$, как и во многих публикациях, наделяются некоторыми свойствами живых разумных существ, которые способны «накапливаться», «концентрироваться» в продуктах обогащения и переработки сырья (химической, металлургической, энергетической и т. п.) при извлечении основных компонентов и иметь «характер поведения» в процессе обогащения и последующего передела. Одновременно в большинстве работ в соответствии с законами геохимии аргументировано отмечается зависимость распределения основных и сопутствующих компонентов в процессах обогащения и последующей переработки от их форм нахождения в исходном сырье и от физико-химических свойств этих компонентов или их минералов-носителей. Становится очевидным, что вместо упомянутых терминов «накапливаются» и «концентрируются», используемых применительно к сопутствующим компонентам, целесообразно подобрать другой, более соответствующий термин, например, «повышается содержание» сопутствующих компонентов, при этом вместо термина «поведение» лучше использовать «распределение». 
9. При реализации крупных технологических нововведений (изобретений, открытий) либо при существенных изменениях конъюнктуры значимость основных и сопутствующих полезных ископаемых и компонентов конкретных месторождений для экономики предприятия и страны может измениться коренным образом, причем неоднократно в течение относительно короткого периода. Значит ли это, что в соответствии с рекомендациями [79, 82] надо каждый раз менять границы разведки, контуры месторождения и т. д.? При этом приводится неоднократно отмечавшийся ранее [66] наглядный в этом отношении пример ОАО «Ковдорский ГОК». Более того, необходимо отметить, что после прекращения производства бадделеита в Южной Африке (месторождение Полабора) ОАО «Ковдорский ГОК» является единственным в мире продуцентом этого уникального высокоценного попутного продукта, используемого в производстве особо тонкой высокотемпературной керамики и наиболее ответственных огнеупорных изделий, поэтому выявление и расширение промышленных запасов этого компонента, количественное обоснование экономических параметров его производства, его рыночной цены и т. п. имеют важное самостоятельное значение для предприятия и страны, несмотря на незначительный его удельный вес в общей стоимости извлекаемых из сырья ценных компонентов на ОАО «Ковдорский ГОК».

10. Применительно к многокомпонентным месторождениям определение минимально-промышленного содержания основного компонента по сравнению с определением минимально-промышленного содержания условного компонента с учетом не только основных, но и всей совокупности промышленно значимых попутных компонентов, кроме того, имеет следующий недостаток. Отдельные части месторождений с относительно низким содержанием основных компонентов (например, геологические блоки, линзы, мощные прослои, обособленные залежи и т. п. в контуре промышленных запасов и непосредственно прилегающие к ним) могут иметь повышенные содержания высокоценных сопутствующих компонентов, которые обеспечивают высокорентабельную их отработку. Следовательно, ограничение изучения сопутствующих полезных ископаемых и компонентов границами разведки основных полезных ископаемых [82] может привести к снижению потенциальной ценности месторождения и утрате значительной части рентабельных конкурентоспособных ресурсов. Кроме того, на стадиях поисковых, оценочных работ и даже разведки месторождений еще не вполне выявляется общая, особенно относительная промышленная и коммерческая, значимость отдельных ценных компонентов многокомпонентного сырья, поэтому обоснованное выявление попутных, основных компонентов и главного из основных, рациональных границ разведочных работ на их основе весьма проблематично.

Таким образом, с экономической точки зрения нецелесообразно не только выделять попутные компоненты, но и ограничивать разведку рамками основного полезного ископаемого или компонента [82]: все без исключения полезные компоненты комплексного сырья целесообразно рассматривать равноправными, а границы разведки устанавливать на основе других геологических и экономических принципов.

11. Удачно подобранная краткая и достаточно емкая фраза о целесообразности извлечения (и учета в промышленных запасах) отдельных ценных попутных компонентов и комплексного использования сырья в целом на экономически рациональной основе, использованная в требованиях ГКЗ 
1973, 1982 и 2007 гг. [24, 79, 126] и во всей последующей нормативнометодической документации, не подкреплена соответствующей методикой и требует хотя бы краткой расшифровки и конкретизации.

Только в одном из документов ГКЗ [82, с. 43] содержится без какого-либо обоснования рекомендация об определении минимального промышленного содержания попутного компонента (только II и III групп, но не I): «...исходя из прямых затрат, связанных с получением конечной товарной продукции по оцениваемому компоненту». Но такая рекомендация содержит явные противоречия. В том же документе [82, с. 31, 32] дано определение: «Минимальное промышленное содержание полезного компонента в подсчетном блоке - это такое содержание, при котором достигается равенство извлекаемой ценности минерального сырья эксплуатационным затратам на получение товарной продукции». Причем ниже разъясняется, что эксплуатационные затраты включают затраты на добычу и обогащение руды, т. е. прямые и косвенные затраты. Следовательно, содержание компонента, определяемого на основе только прямых затрат без учета косвенных, заведомо не может покрыть извлекаемой ценностью эксплуатационные затраты, включающие, кроме прямых, хотя бы часть косвенных, к которым, безусловно, относятся затраты на добычу многокомпонентного сырья. В этой связи необходимо детально проанализировать различные предложения исследователей по проблемам оценки промышленной значимости отдельных ценных компонентов в многокомпонентном минеральном сырье и, соответственно, определения минимального их содержания, при превышении которого ценный компонент признается промышленно значимым и должен учитываться в промышленных запасах конкретных месторождений.

\subsection{3. Методика расчета предельных содержаний ценных компонентов в полиметаллических рудах для целей их комплексной переработки}

Методику определения минимального промышленного содержания рассеянных элементов в комплексном сырье на экономической основе впервые предложил В.Н. Виноградов [20]. Им была отмечена условность понятия «минимальное промышленное содержание» применительно к отдельному полезному компоненту комплексного сырья. В основу методики он положил принцип окупаемости затрат, относимых на получение каждого рассеянного элемента. В сущности, при этом используется подход, аналогичный применяемому в индивидуальных, т. е. некомплексных, производствах, несмотря на то что определение себестоимости рассеянных элементов имеет некоторые особенности. Например, В. Н. Виноградов рекомендует не учитывать затраты на добычу и первые стадии переработки комплексного сырья в себестоимости рассеянных элементов. К тому же в себестоимость рассеянных элементов, кроме прямых затрат, им включается часть косвенных расходов по операциям комплексной переработки полупродуктов металлургического передела, которые содержат несколько рассеянных (а равным образом и других) ценных элементов. Следовательно, используется методика калькулирования себестоимости рассеянных элементов, предложенная ранее в работе [70]. Однако авторами указанной работы при калькуляции рассеянных элементов рекомендуется исключить сырьевую составляющую ввиду, как правило, небольшой ее доли в полной их себестоимости, т. е. не из теоретических, а практических соображений. 
Аналогичная методика определения предельных содержаний рассеянных элементов в комплексном сырье позднее была предложена А. М. Быбочкиным и А. М. Сечевицей $[17,114]$. Однако Ф. Д. Ларичкин [65] ввел в научный оборот использованный ими термин ранее, кроме того, им определено понятие и предложена принципиально иная методика определения количественной величины предельных (браковочных) содержаний каждого из ценных компонентов (включая все без исключения основные и сопутствующие) в полиметаллическом (комплексном вообще) сырье, ниже которых их получение, а следовательно, и учет в промышленных запасах, экономически не оправдано. Обоснованность методики подтверждена результатами последующих исследований и ее практической реализацией на ряде казахстанских полиметаллических месторождений и предприятий свинцово-цинковой промышленности [66-68].

В соответствии с предложенным понятием [66-68] под предельным (браковочным) понимается такое минимальное содержание ценного компонента в комплексном сырье, ниже которого его извлечение, при условии комбинированной комплексной переработки сырья, экономически неэффективно на конкретном этапе развития производства. Предельные (или браковочные) содержания ценных компонентов определяются в дополнение к минимально-промышленному содержанию условного металла (основного, профилирующего, ведущего, главного компонента) из условия окупаемости только прямых затрат, непосредственно и неизбежно связанных с организацией получения именно данного компонента из комплексного сырья без учета какой-либо части косвенных расходов, необходимых для производства двух и более (или всех) извлекаемых компонентов [66-68].

По своей сути и определению предельные браковочные содержания каждого из ценных компонентов многокомпонентного минерального сырья соответствуют рекомендуемому ГКЗ подходу по аналитическому расчету бортового содержания компонентов (см. [82, пункт 78, с. 29]).

В работах [66-68] дополнительно уточнено, что минимальнопромышленное содержание условного компонента, рассчитываемое по методическим указаниям [82], должно определяться из условия окупаемости общей суммы прямых и косвенных затрат на добычу и многопродуктовую комплексную переработку многокомпонентного сырья при учете только тех ценных компонентов (как основных, так и сопутствующих), содержания которых в данном сырье не ниже их предельного (браковочного). Запасы многокомпонентного сырья и отдельных ценных компонентов в нем относятся к промышленным только при условии одновременного выполнения двух условий: 1) содержания каждого ценного компонента (основных и сопутствующих) не ниже соответствующих предельных браковочных; 2) их суммарное содержание в переводе на условный компонент не ниже минимального промышленного содержания условного компонента.

Таким образом, вместо интуитивного субъективного подхода впервые предложена экономически обоснованная и проверенная на практике методика количественного расчета главных параметров кондиций для оконтуривания и подсчета промышленных запасов многокомпонентного минерального сырья и каждого из ценных компонентов в нем, обеспечивающая максимальную экономическую эффективность комбинированного комплексного использования многокомпонентного сырья в целом с учетом рационального перечня его ценных составляющих, подлежащих извлечению при комбинированной переработке. 
Необходимо подчеркнуть, что изложенный подход распространяется на все без исключения основные и попутные ценные компоненты минерального сырья (не только рассеянные элементы), что позволяет существенно расширить промышленные запасы комплексных месторождений и повысить экономическую эффективность их эксплуатации. Кроме того, понятие и методика количественного определения предельных (браковочных) содержаний ценных компонентов в многокомпонентном минеральном сырье и разнообразных продуктах его переработки на разных стадиях производства позволяет существенно облегчить и упростить решение таких важных практических вопросов, как разбраковка отдельных залежей, промежуточных продуктов разных стадий производства, определение рациональных границ валовой и селективной выемки и переработки, шихтовки сырья различного (переменного) состава, отключения технологической ветви получения отдельных компонентов при снижении их содержаний в сырье ниже браковочного и т. п.

По предложенной методике всего по семнадцати элементам в полиметаллическом сырье обогатительного и металлургического переделов для типичных (средних) условий свинцово-цинковой подотрасли цветной металлургии определены предельные содержания всех основных и сопутствующих компонентов [65]. В последующих работах указанный подход был развит и подтвержден новыми аргументами, а также одобрен рядом предприятий и организаций, использован Казгипроцветметом при обосновании кондиций и подсчете промышленных запасов полиметалличесих руд и отдельных ценных компонентов в них по ряду казахстанских месторождений, утвержденных ГКЗ СССР с высокой оценкой [91].

Применительно к горно-обогатительным предприятиям в прямые затраты (3 п) включаются следующие расходы: на обогатительные доводочные, контрольные операции, сгущение, фильтрацию, сушку, складирование и хранение концентрата; коммерческие расходы, включающие затаривание, погрузо-разгрузочные операции, транспорт до пункта отправления, погрузку в вагон (судно) и другие, которые имеют место быть; прямые затраты по конкретному концентрату (например, связанные с оформлением документов, почтово-телеграфные расходы, в том числе по экспортным операциям, включая таможенные платежи). Ресурсные платежи (Р) включают фактически уплачиваемые налоги на добычу полезных ископаемых (НДПИ) и на воспроизводство МСБ (официально отменены с 2002 г.), акцизы (по соответствующим полезным ископаемым) [91].

В соответствии с введенными выше условными обозначениями предельные (браковочные) содержания ( $\left.\alpha_{i \text { пр }}\right)$ рассчитываются по формулам: 1$)$ в добытой руде, полуфабрикате, концентрате $\left(\alpha^{1}{ }_{i \text { пр }}, \%\right)$ :

$$
\alpha_{i \text { пр }}=\frac{\left(3_{\Pi}+\mathrm{P}\right)_{i}}{\varepsilon_{i} \times \bigsqcup_{i}} \times 100 ;
$$

$2)$ в руде геологической, в недрах $\left(\alpha_{i \text { пр }}, \%\right)$ :

$$
\alpha_{i \text { пр }}=\frac{\left(3_{\Pi}+\mathrm{P}\right)_{i}}{\varepsilon_{i} \times Ц_{i}(1-R)} \times 100,
$$

где $i$ - номер ценного компонента, концентрата; $\varepsilon_{i}-$ извлечение $i$-го ценного компонента в готовую продукцию, доли единицы; $\bigsqcup_{i}-$ рыночная цена одной 
тонны $i$-го ценного компонента в готовой продукции, руб.; $R$ - коэффициент разубоживания руды при добыче, доли единицы.

В таблице 4.3 представлены рассчитанные предельные (браковочные) содержания ценных компонентов для условий ОАО «Апатит» и ОАО «Ковдорский ГОК» в ценах и условиях 2002 г. [91] по рекомендуемой и традиционной методике, изложенной в работах $[17,114]$ и не учитывающей особенности экономики комплексной переработки сырья.

Таблий 4.3

Предельные (браковочные) и минимально-промышленные содержания ценных компонентов в рудах Мурманской области (2002 г.)

\begin{tabular}{|l|r|r|r|r|}
\hline \multirow{2}{*}{$\begin{array}{c}\text { Ценный } \\
\text { компонент }\end{array}$} & $\begin{array}{c}\text { Предельное (браковочное) } \\
\text { содержание по методике }\end{array}$ & $\begin{array}{c}\text { Минимально- } \\
\text { промьшленное } \\
\text { содержание }\end{array}$ & $\begin{array}{c}\text { Среднее } \\
\text { содержание в } \\
\text { предлагаемой }\end{array}$ \\
\hline \multicolumn{5}{|c|}{ традиционной руде } \\
\hline \multicolumn{5}{|c|}{ ОАО «Апатитл» } \\
\hline $\mathrm{P}_{2} \mathrm{O}_{5}$ & 2,1 & 9,0 & 9,5 & 13,8 \\
\hline $\mathrm{Al}_{2} \mathrm{O}_{3}$ & 3,4 & 10,8 & 22,9 & 14,6 \\
\hline \multicolumn{5}{|c|}{ ОАО «Ковдорский ГОК» } \\
\hline $\mathrm{Fe}_{\text {об̆. }}$ & 2,0 & 27,8 & 34,7 & 24,2 \\
\hline $\mathrm{P}_{2} \mathrm{O}_{5}$ & 1,1 & 6,2 & 13,1 & 7,0 \\
\hline $\mathrm{ZrO}_{2}$ & 0,016 & 0,08 & 1,1 & 0,15 \\
\hline
\end{tabular}

Для наглядности рассчитанные предельные (браковочные) содержания сопоставляются с фактическими средними содержаниями ценных компонентов в добытых рудах, а также с их минимально-промышленными содержаниями при условии одностороннего (некомплексного) использования сырья для производства только оцениваемого компонента.

Полученные данные свидетельствуют о том, что рентабельная отработка Ковдорского месторождения может быть обеспечена только при условии комбинированной многопродуктовой переработки добываемой руды, одностороннее еe использование для производства любого из ценных составляющих убыточно. Предельные содержания компонентов, определенные по традиционной методологии в соответствии с работами $[17,114]$, мало отличаются от их минимально-промышленных содержаний при монопродуктовой переработке руд и существенно не влияют на выводы о сравнительной эффективности комбинированного комплексного производства. Это связано с тем (как показано в [91]), что учет какой-либо части косвенных затрат, которые не меняются при расширении (изменении вообще) номенклатуры извлекаемых компонентов, ведет к завышению величины расходов, необходимых и неизбежных для организации производства оцениваемого компонента, и, следовательно, существенно сужает экономически эффективные границы комбинированного КИМС.

Соответственно, методика определения предельных (браковочных, бортовых) содержаний ценных компонентов в многокомпонентном сырье, исходя из условия окупаемости только прямых затрат на их производство, позволяет учитывать специфические особенности комбинированных многопродуктовых комплексных производств и более обоснованно оконтуривать месторождения 
многокомпонентных руд, тем самым способствуя более рациональному использованию и охране недр.

Техническая возможность извлечения ценных компонентов из руд даже краевых зон с содержаниями, близкими к предельным (фактически перерабатывается усредненная шихта из руд разных добычных участков), подтверждается результатами исследований [58] по обогащению нескольких проб вмещающих пород Партомчоррского месторождения (табл. 4.4). Следует отметить, что основной целью указанной работы было получение кондиционного нефелинового концентрата при комбинированной переработке сырья. Наряду с этим, из всех пяти проб получено пять стандартных концентратов (апатитовый, нефелиновый, титаномагнетитовый, эгириновый и сфеновый).

Таблица 4.4

Показатели извлечения $\mathrm{P}_{2} \mathrm{O}_{5}$ из вмещающих пород

Партомчоррского месторождения

\begin{tabular}{|c|l|c|c|c|}
\hline \multirow{2}{*}{$\begin{array}{c}\text { № } \\
\text { пробы }\end{array}$} & \multicolumn{1}{|c|}{ Наименование } & \multicolumn{2}{|c|}{ Содержание $\mathrm{P}_{2} \mathrm{O}_{5}, \%$} & \multirow{2}{*}{$\begin{array}{l}\text { Извлечение } \\
\mathrm{P}_{2} \mathrm{O}_{5}, \%\end{array}$} \\
\cline { 2 - 4 } & в пробе & в концентрате & 91,7 \\
\hline 8 & $\begin{array}{l}\text { Бедная апатитонефелиновая руда } \\
\text { в контуре проектной выемки }\end{array}$ & 2,72 & 38,0 & 97,0 \\
\hline 9 & $\begin{array}{l}\text { Сфено-титаномагнетитовые } \\
\text { ийолит-уртиты (висячий бок) }\end{array}$ & 2,90 & 37,0 & 93,8 \\
\hline 10 & $\begin{array}{l}\text { Апатитовые уртиты (лежачий } \\
\text { бок) }\end{array}$ & 2,24 & 35,0 & 76,0 \\
\hline 11 & $\begin{array}{l}\text { Трахитоидные ийолит-уртиты } \\
\text { (покрывающие породы) }\end{array}$ & 0,90 & 34,7 & 62,0 \\
\hline
\end{tabular}

Вышеизложенное свидетельствует о принципиальной возможности существенного снижения содержания ценных компонентов в промышленных запасах многокомпонентных руд, возможности расширения сырьевой базы без дополнительных вложений при условии развития комбинированного комплексного использования ресурсов недр, а также создает реальные предпосылки рентабельной комплексной утилизации техногенного сырья - различных ГПО, содержания ценных компонентов в которых зачастую выше, чем в отрабатываемых в настоящее время рудах. Рекомендуемая методика обоснования параметров кондиций $[91,92]$, учитывающая особенности комплексных многономенклатурных производств, повышает обоснованность и существенно облегчает процедуру оконтуривания месторождений многокомпонентных руд, разбраковку отдельных участков, залежей, многообразных промежуточных продуктов комплексной переработки сырья, включая ГПО разных стадий производства. При этом необходимо учитывать специфические технико-экономические особенности повторной добычи и переработки ГПО, в частности, что ресурсные налоги на отходы не распространяются.

Таким образом, использование ГПО в качестве сырья для производства строительных материалов или при приготовлении закладочных смесей возможно 
без ограничений только в случае, если фактические содержания в них всех ценных компонентов ниже соответствующих им предельных (браковочных); иначе они должны быть отнесены к потенциальным минеральным ресурсам.

Необходимо отметить, что в 2016-2017 гг. в Федеральном законе от 3 июля 2016 г. № 279-Ф3 и Постановлении Правительства РФ от 12 августа 2017 г. № 963 «О критериях отнесения полезных ископаемых к попутным полезным ископаемым (за исключением попутных вод, углеводородного сырья и общераспространенных полезных ископаемых)» дано следующее определение, установлены три критерия отнесения полезных ископаемых к попутным ${ }^{85}$ и внесены соответствующие изменения в Закон «О недрах»: 1) вместе с полезным ископаемым, указанным в лицензии, залегают в недрах или содержатся в отходах добычи или во временно неиспользуемых продуктах производства; 2) невозможна или экономически нецелесообразна самостоятельная добыча полезных ископаемых, признаваемых попутными, из недр, из отходов добычи или из временно неиспользуемых продуктов производства; 3) расчётная стоимость полезного ископаемого, признаваемого попутным, при его добыче не превышает $10 \%$ общей стоимости всех полезных ископаемых, учтённых Государственным балансом запасов полезных ископаемых на участке недр. В сентябре 2019 г. в Государственную думу внесен законопроект о возможности добычи попутных полезных ископаемых и при добыче углеводородного сырья.

Анализ изложенного показывает, что в рассматриваемых новых правовых документах в отличие от методических указаний ГКЗ РФ речь идет только о попутных полезных ископаемых, а не о попутных полезных компонентах многокомпонентного минерального сырья и возможности их производства при комбинированной комплексной переработке. Иными словами, проблемы обоснованного определения понятий основного (основных) и попутных ценных компонентов многокомпонентного минерального сырья не решаются. Соответственно, не рассматриваются проблемы экономической эффективности комплексного освоения ресурсов недр и комбинированной переработки многокомпонентного минерального сырья, включая техногенное. Кроме того, практическая реализация предложенных определений и критериев новых правовых документов принципиально возможна только применительно к месторождениях, на которые уже выданы лицензии, т. е. которые относятся к распределенному фонду недр и, соответственно, не могут использоваться на стадии геологоразведочных работ.

\section{Выводы по главе 4}

Формирование эффективной системы недропользования, в основе которой заложено комбинированное комплексное освоение и использование всей совокупности ресурсов недр, применение малоотходных ресурсосберегающих технологий, экологизация производства и обеспечение конкурентоспособности продукции МСК на мировом рынке, не может рассматриваться как однократное действие. Его следует рассматривать как сложный, многоэтапный, непрерывный

85 Официальный интернет-портал правовой информации, 17.08.2017. URL: http://www.pravo.gov.ru; Собрание законодательства РФ. № 34, ст. 5287, 21.08.2017 // КонсультантПлюс: сайт. URL: http://www.consultant.ru/law/hotdocs/50660.html/ (дата обращения: 25.10.2019). 
итерационный процесс, который требует глубоких теоретических, методологических исследований, обобщений, моделирования и практических проработок, а также диагностики, координации, мониторинга, контроля и коррекции. Необходим учет специфики и закономерностей комплексных производств, включая пересмотр традиционных подходов и понимания многих экономических категорий, принципов, методов и оценок.

Объективный переход ГПО из категории бросовых в период их образования в категорию потенциально полезных, а затем фактически полезных после разработки эффективной технологии их утилизации на практике осложняет и зачастую препятствует их производительному использованию. Это обусловлено тем, что предприятия - владельцы отходов желают получить достаточно ощутимую дополнительную прибыль, но любая, даже чисто символическая, цена вчера еще никому ненужных отходов психологически отталкивает возможных потребителей, а при определенной величине вообще исключает возможность получения прибыли потенциальными потребителями.

Для эффективного решения проблемы рекомендуется процесс формирования взаимоприемлемой для контрагентов цены на договорной основе с использованием процедур сближения, согласования (уторговывания) позиций. В частности, оценка экономической эффективности утилизации отходов (для народного хозяйства в целом) должна осуществляться при нулевой стоимости отходов, а их окончательная договорная цена определяться из согласованного распределения между участниками общего экономического эффекта конкретного проекта утилизации отходов, на основе оценки вклада каждого участника в реализацию совместного проекта.

Оценка экономической эффективности комплексной утилизации ГПО как важной составной части георесурсов должна основываться на системном подходе и учитывать геологические, технологические, экономические, природоохранные и социальные аспекты по всему циклу добычи, комбинированной переработки и обращения с вторичными отходами по принципу «от земли до земли». При этом экономическая эффективность производства каждого из ценных компонентов техногенного сырья определяется из условия окупаемости только прямых дополнительных затрат, непосредственно связанных с его извлечением из ГПО.

В дополнение к минимально-промышленному содержанию условного (основного целевого) компонента разработана методика аналитического определения предельного (браковочного, бортового) содержания каждого ценного составляющего многокомпонентного техногенного горнопромышленного сырья, обеспечивающая повышение обоснованности оконтуривания и подсчета промышленных запасов многокомпонентного техногенного сырья. Предельные (браковочные, бортовые) содержания каждого из ценных компонентов определяются из условия окупаемости только прямых дополнительных затрат, возникающих при организации его производства, а при определении минимально-промышленного содержания условного компонента необходимо включать в расчет только те ценные составляющие, содержания которых выше соответствующего предельного (браковочного, бортового).

Использование ГПО в качестве сырья для производства строительных материалов или при приготовлении закладочных смесей возможно без ограничений только в случае, если фактические содержания в них всех ценных компонентов ниже соответствующих им предельных (браковочных, бортовых); иначе они должны быть отнесены к потенциальным минеральным ресурсам. 


\section{5. ОЦЕНКА ЭКОНОМИЧЕСКОЙ ЭФФЕКТИВНОСТИ ОСВОЕНИЯ РАЗВЕДАННЫХ ЗАПАСОВ ТЕХНОГЕННОГО МЕСТОРОЖДЕНИЯ НА ПРИМЕРЕ ОТКРЫТОГО АКЦИОНЕРНОГО ОБЩЕСТВА «КОВДОРСКИЙ ГОК» МУРМАНСКОЙ ОБЛАСТИ}

\section{1. Обобщенные результаты изучения отходов обогащения первого поля хвостохранилища}

Отходы переработки магнетитовых и апатитовых руд Ковдорского месторождения складируются в хвостохранилище: в период 1962-1981 гг. в первое поле, с 1982 г. по настоящее время - во второе поле. Основной объем первого поля хвостохранилища сформирован в 1975 г. до ввода в эксплуатацию АБОФ и представлен хвостами ММС, обогащенными апатитом и бадделеитом. Вопрос о возможности и целесообразности вторичной переработки отходов первого поля хвостохранилища для получения апатитового и бадделеитового концентратов возник в связи с необходимостью решения проблемы рационального использования руд Ковдорского месторождения, поставленной еще в 1976 г. [27].

На первом этапе Ено-Ковдорской геологоразведочной партией Мурманской геологоразведочной экспедиции в 1976 г. была проведена разведка залежи хвостов. Было пройдено 99 шнековых скважин по сети 100 х 100 м и 12 скважин большого диаметра по сети 200 х 200. Отобраны 1110 рядовых и 146 групповых проб. Технологические свойства песков изучены на пробе весом 2,5 т. Рядовые пробы анализировались на $\mathrm{Fe}_{\text {вал. }}, \mathrm{P}_{2} \mathrm{O}_{5}, \mathrm{CaO}, \mathrm{CO}_{2}, \mathrm{ZrO}_{2}$, групповые, кроме того, на серу, $\mathrm{Nb}_{2} \mathrm{O}_{5}, \mathrm{Ta}_{2} \mathrm{O}_{5}$. Отходы обогащения (хвосты) первого поля хвостохранилища представляют собой тонкоизмельченный материал, более 70 \% зерен которого имеют крупность более 0,071 мм. Количество тонких фракций (-0,071 мм) увеличивается с глубиной, крупных - в направлении границ залежи с рельефом поверхности.

Институтом «Механобр» [116] и Горным институтом КФАН СССР [2] в 1976 г. выполнены лабораторные технологические испытания и установлена возможность извлечения апатита из хвостов ММС. В обоих случаях был получен апатитовый концентрат, содержащий 35-37 \% $\mathrm{P}_{2} \mathrm{O}_{5}$ при извлечении в операции флотации 54-56 $\%$. Товарное извлечение $\mathrm{P}_{2} \mathrm{O}_{5}$ будет, соответственно, значительно ниже. Возможность извлечения бадделеита на этом этапе не изучалась. Подсчитанные запасы техногенного сырья составили 36,9 млн т с содержанием $\mathrm{P}_{2} \mathrm{O}_{5} 12,48$ \% и $\mathrm{ZrO}_{2}$ 0,31 \%.

Институтом «Гипроруда» по этим показателям в 1977 г. был выполнен технико-экономический доклад, в котором было показано, что ввиду низких технологических показателей использование лежалых хвостов для получения апатитового концентрата на тот период времени было признано нецелесообразным. Исследования по переработке хвостов были приостановлены. В это же время начали меняться их качественные характеристики в связи с вовлечением в переработку маложелезистых и редкометалльных руд и введением в строй АБОФ.

Второй этап геолого-технологического изучения отвальных песков первого поля хвостохранилища начался в 1987 г., в ходе реализации Постановления ЦК КПСС и Совмина СССР «О мерах по развитию промышленности минеральных удобрений... в 1986-1990 гг.». Минудобрений и Минчермет приступили к научноисследовательским и опытным работам по технологии обогащения хвостов текущей переработки и накопленных ранее с целью получения сырья для производства 
плавленых фосфорно-магниевых удобрений и разработки ТЭО строительства предприятия по производству плавленых фосфатов. Изменение качества сырья и увеличение масштабов техногенной залежи обусловили необходимость повторной разведки хвостов первого поля.

Разведка была выполнена силами Ено-Ковдорской геологоразведочной партии при участии ГОКа, проведен комплекс полупромышленных технологических исследований (ГоИ КНЦ РАН, Механобр, Ковдорский ГОК). Применение перспективного флотореагента «Флотол 7.9» марки «В» и вспенивателя «Оксаль (Т80)» обеспечило получение апатитового концентрата с содержанием $\mathrm{P}_{2} \mathrm{O}_{5} 36,2-36,86$ $\%$ при извлечении 80,2-81,5\%. Отчет о результатах работ был рассмотрен центральной комиссией по запасам Минчермета СССР (протокол от 11 марта 1993 г № 3617), запасы техногенного сырья утверждены территориальной комиссией по запасам Мурмангеолкома (протокол от 8-24 мая 1996 г. № 9-96) в количестве 68,2 млн т при содержании $\mathrm{P}_{2} \mathrm{O}_{5} 10,79 \%$ и $\mathrm{ZrO}_{2} 0,257 \%$.

Институтом «Гипроруда» была оценена целесообразность строительства предприятия по производству плавленых фосфорно-магниевых удобрений мощностью до 600 тыс. т в год, однако дело ограничилось созданием опытной фабрики по производству плавленого фосфорно-магниевого удобрения, действовавшей с 1991 по 1995 гг.

Опытно-промышленная эксплуатация ТМ в пределах первого поля хвостохранилища была начата Ковдорским ГОКом в сентябре 1995 г. [56], а промышленная эксплуатация [38] (производство горных работ, осушение карьерного поля, транспорт и электроснабжение объектов карьера) в соответствии с проектом ОАО «Гипроруда» и НИПЕЦ «Промгидротехника» с 30 декабря 1998 г. За время опытно-промышленной разработки до 1 января 1997 г. из хвостохранилища добыто 3,6 млн т хвостов с долей материала класса крупности -0,071 мм 10,28 \%, с содержанием $\mathrm{P}_{2} \mathrm{O}_{5} 9,6 \%, \mathrm{ZrO}_{2} 0,302 \%$.

В процессе работ обнаружился недостаток информации относительно качества и гранулометрического состава хвостов, гидрологических и гидрогеологических условий ТМ. В связи с этим в 1997 г. на основе утвержденного проекта «Ковдорский ГОК» приступил к доизучению залежи, в результате которого был произведен пересчет запасов техногенного сырья по состоянию на 1 января 2000 г. в количестве 45,6 млн т с содержанием $\mathrm{P}_{2} \mathrm{O}_{5} 10,65 \%$ и $\mathrm{ZrO}_{2} 0,266 \%$.

Промышленная эксплуатация хвостов первого поля прекращена в декабре 2003 г. в связи с увеличением добычи и переработки руд основного месторождения, возобновлена в 2006 г. в связи со снижением сбыта железорудного концентрата. Отходы обогащения магнетитовых и апатитовых руд, заскладированных во второе поле хвостохранилища, не изучались. Сведения об их количестве и качестве ограничивались отчетными данными предприятия о размещаемых текущих отвальных отходах (хвостах) обогащения.

После выхода Постановления ЦК КПСС и СМ СССР от 11 сентября 1985 г.

№ 874 были возобновлены работы по изучению обогатимости лежалых хвостов первого поля в Горном Институте КНЦ РАН на пробах, сформированных послойно. В результате исследований было установлено, что длительное нахождение отходов магнитной сепарации в хвостохранилище привело к ухудшению обогатимости хвостов из-за их изменения, что в большей мере относится к нижним горизонтам. Для получения высококачественных апатитовых концентратов были рекомендованы 
операции «щадящего» измельчения, глубокого обесшламливания и флотации с собирателем «Флотол 7,9» марки «Б».

Применение «Флотола 7,9» марки «Б» и трех перечистных операций позволило получить из проб всех слоев хвостохранилища апатитовый концентрат, содержащий порядка 38 \% $\mathrm{P}_{2} \mathrm{O}_{5}$ при извлечении $\mathrm{P}_{2} \mathrm{O}_{5}$ от 48,9 до 60,9\%. Кроме того, по гравитационно-магнитной схеме, включающей концентрацию на винтовых сепараторах, концентрационных столах и магнитную сепарацию, был получен первичный бадделеитсодержащий продукт.

В 1996 г. лабораторией обогащения ОАО «Ковдорский ГОК» изучалась обогатимость технологических проб хвостов, отобранных работниками предприятия. Пробы анализировались на содержание $\mathrm{FeO}, \mathrm{Fe}_{\text {магн., }} \mathrm{P}_{2} \mathrm{O}_{5}, \mathrm{CO}_{2}, \mathrm{SiO}_{2}, \mathrm{MgO}, \mathrm{CaO}, \mathrm{ZrO}_{2}$,

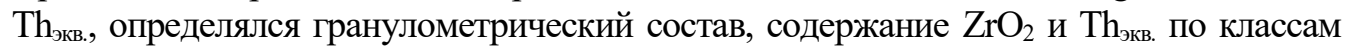
крупности и содержание циркона, кальцита, доломита, оценивалось состояние поверхности минералов. Испытания показали, что обогатимость хвостов напрямую зависит от их крупности. Качественные апатитовые концентраты с применением фабричных реагентов были получены из проб, содержание в которых класса менее 0,071 мм не превышало $35 \%$. С «Флотолом 7,9» только в одном случае, когда содержание частиц менее 0,071 мм было $78 \%$, получился некондиционный концентрат (32\% $\left.\mathrm{P}_{2} \mathrm{O}_{5}\right)$. По остальным пробам содержание $\mathrm{P}_{2} \mathrm{O}_{5}$ в концентратах варьировало от 38,0 до 40,9 \%, при этом с увеличением содержания мелких классов растут потери апатита при обесшламливании, снижается содержание извлекаемого гравитационными методами бадделеита.

В 1997-2001 гг. в рамках работ по доизучению ТМ первого поля в лабораторных условиях на опытной фабрике «Ковдорского ГОКа» было исследовано тридцать МТП, кроме того, испытывались МТП, отобранные из скважин эксплуатационной разведки, забоев карьера и усреднительных складов. Результаты испытаний подтвердили ранее сделанный вывод о том, что основным фактором, определяющим качество апатитовых концентратов и извлечение $\mathrm{P}_{2} \mathrm{O}_{5}$ в концентраты, является фракционный состав исходного сырья. При обогащении МТП с содержанием фракции менее 0,071 мм более 40 \% лишь в единичных случаях получают апатитовый концентрат с содержанием $\mathrm{P}_{2} \mathrm{O}_{5} 38$ $\%$ и более, а БК при таком фракционном составе на имеющемся оборудовании и существующей технологии вообще получить невозможно, так как материал при переработке уходит в шламы. При содержании фракции менее 0,071 мм до 40 \% получаются требуемые по качеству бедделеитовые и апатитовые концентраты при достаточно высоком извлечении. В редких случаях при содержании класса менее 0,071 мм от 30 до 40 \% не получаются концентраты нужного качества.

С 2000 по 2002 гг. Горным институтом КНЦ РАН выполнена работа по совершенствованию технологии обогащения апатит-бадделеитовых продуктов на АБОФ с целью повышения качества апатитового и бадделеитового концентратов. Результаты показали, что из лежалых хвостов, содержащих от 39 до $75 \%$ класса менее 0,071 мм, с использованием скорректированного фабричного реагентного режима и введением дополнительной перечистной флотации без применения измельчения, но с применением обесшламливания по классу 30 мкм получаются апатитовые концентраты с содержанием 36-39 \% $\mathrm{P}_{2} \mathrm{O}_{5}$ при извлечении $35-50 \%$.

Одновременно с совершенствованием технологии получения апатитового концентрата с 1998 г. Институт химии и технологии редких элементов и 
минерального сырья КНЦ РАН совместно с ОАО «Ковдорский ГОК» разработал в лабораторном масштабе технологию химической переработки некондиционного БК, по которой из чернового БК с крупностью зерен - $0,044+0$, содержавшего около $90 \%$ $\mathrm{ZrO}_{2}$ и повышенную концентрацию радиоактивных примесей, можно получить БК сорта ПБ-1 по ТУ 48-0572-17-252-91. На основании полученных данных лабораторных исследований было принято решение о проведении опытнопромышленных испытаний по разработанной технологии. Однако при проведении работ цель несколько изменилась - появилась необходимость в опытнопромышленном масштабе оценить возможность применения предлагаемых химических подходов повышения качества БК (патент № 2139250 РФ) для более глубокой очистки товарного БК, загрязненного радиоактивными примесями. Проведенные испытания показали возможность достаточно глубокой очистки БК химическим методом, в том числе и от радиоактивных примесей, были определены технологические режимы проведения сернокислотной очистки БК. Были наработаны партии очищенного БК, содержание в которых $\mathrm{ZrO}_{2}+\mathrm{HfO}_{2}$ превышало 99,4 \%, были проверены основные аппаратурные решения, определен круг вопросов, которые необходимо решить в дальнейшем.

Следующим объектом исследования были хвосты первой и второй стадий доводки чернового БК с целью исследования возможности получения из хвостов доводки чернового БК товарного БК, который по качеству соответствовал бы ТУ 1762-003-001186759-2000. Разработана технология получения диоксида циркония сорта ЦРО-1 по ГОСТ 21907-76 из хвостов доводки чернового БК. В результате была разработана комбинированная технология (включающая методы механического и химического обогащения) получения БК сорта ПБ-2 из класса менее 0,071 мм хвостов магнитного сепаратора 2ОССЭ первой и второй стадий доводки. Кроме того, была разработана технология получения диоксида циркония сорта ЦРО-1 по ГОСТ 21907-76 из хвостов доводки чернового БК.

Эти исследования позволили внедрить в промышленное производство наиболее рациональную и максимально приближённую к условиям действующего производства схему добычи и переработки лежалых хвостов первого поля хвостохранилища [93] и, минуя процесс ММС, извлекать на свободных мощностях АБОФ с небольшой модернизацией технологии апатитовый и бадделеитовый концентраты $[27,122]$.

Разработка ТМ первого поля осуществляется на запасах, разведанных в 1987-1992 гг. Добыча и транспортировка сырья ТМ осуществляется штатным оборудованием предприятия - экскаваторами ЭКГ-8И и автосамосвалами грузоподъёмностью 110-136 т - $\mathrm{c}$ размещением на усреднительнонакопительных складах на борту карьера и у приемных бункеров дробильной фабрики, где в теплые периоды года сырье теряет излишнюю влагу. В процессе добычи осуществляется предварительная очистка хвостов от посторонних предметов (деревьев, кусков буровых и пульпопроводящих труб, остатков бетонных эстакад и пр.).

Обезвоженный материал подается автосамосвалами в приемные бункеры корпуса крупного дробления, затем системой конвейеров - в корпус среднего и мелкого дроблений, где с помощью грохотов выделяют древесину и мерзлые включения. Далее через бункеры корпуса МОФ хвосты направляют на измельчение в шаровые мельницы. Измельченный продукт по трубопроводам 
перекачивают на АБОФ для получения последовательно апатитового и бадделеитового концентратов.

Апатитовое производство включает в себя цикл подготовки питания флотации (измельчение и сгущение) и флотацию с получением апатитового концентрата, который после сгущения, фильтрования и сушки поступает на склад, откуда отгружается потребителям. Из хвостов апатитовой флотации гравитационными и флотационными методами получают черновой БК. После доводки сухой товарный БК затаривают в мягкие контейнеры (по 1 т) и отгружают потребителям.

Остатки запасов на 1 января 2002 г. с учётом доразведки месторождения в 1997-2000 гг. составляли 48 млн т с содержанием $10,7 \% \mathrm{P}_{2} \mathrm{O}_{5}, 0,27 \% \mathrm{ZrO}_{2}$ и $56,9 \%$ класса $-0,071$ мм. Таким образом, количество мелких фракций в добываемом техногенном сырье по сравнению с первоначальным периодом существенно возросло.

Результаты переработки лежалых хвостов приведены в табл. 5.1, из которой видно, что содержание в хвостах ценных компонентов выше, чем в первичной руде из основного карьера $\left(\mathrm{P}_{2} \mathrm{O}_{5} 7,12-7,19 \% . \mathrm{ZrO}_{2} 0,15-0,16 \%\right)$. Качественные показатели обогащения лежалых хвостов, за исключением извлечения $\mathrm{P}_{2} \mathrm{O}_{5}$, в начальный период практически находились на уровне показателей при переработке руд коренного месторождения [34], с вовлечением в переработку все в больших объемах тонкозернистых хвостов нижних горизонтов извлечение $\mathrm{P}_{2} \mathrm{O}_{5}$ в апатитовый концентрат существенно снижается.

Анализ результатов исследований по изучению обогатимости хвостов нижних горизонтов, характеризующихся высокой степенью ошламования, показал, что для получения кондиционного апатитового концентрата необходимо изменение реагентных режимов флотации и схемы обогащения за счет совершенствования процесса подготовки исходного питания. Были испытаны различные методы активации тонкозернистого апатита: оттирка; оттирка, совмещенная с отмывкой в разбавленных и плотных пульпах; селективная флокуляция; температурная обработка пульпы; новые реагентные режимы флотации. Положительные результаты при переработке проб хвостов с содержанием класса -0,071 мм от 57 до 75,5 \% получены при комплексном воздействии на тонкозернистые продукты, предусматривающем глубокое доизмельчение, повышение температуры пульпы до $25-28^{\circ} \mathrm{C}$ и использование в качестве депрессора сульфит-спиртовой барды вместо жидкого стекла или их смеси.

Разработка запасов выше установившегося уровня грунтовых вод в теле залежи (+279 м) затруднений не вызывала. Отработка же запасов ниже уровня грунтовых вод потребовала решения проблем по отводу поверхностного стока ручья и эффективного способа осушения ТМ в увязке его с технологией разработки залежи, соответственно, дополнительных расходов. Вовлечение в добычу запасов ниже уровня грунтовых вод увязывалось с решением двух главных проблем: отвод поверхностного стока ручья Можель; выбор эффективного способа осушения лежалых хвостов и увязка его с технологией разработки залежи. 
Показатели переработки лежалых хвостов первого поля хвостохранилища ОАО «Ковдорский ГОК»

\begin{tabular}{|c|c|c|c|c|c|c|c|c|c|c|c|c|c|c|c|c|}
\hline Показатель & 1995 & 2000 & $2005^{*}$ & 2006 & 2007 & 2008 & 2009 & 2010 & 2011 & 2012 & 2013 & 2014 & $2015^{* *}$ & 2016 & $2017^{* *}$ & $2018^{* *}$ \\
\hline $\begin{array}{l}\text { Переработка хвостов, } \\
\text { млн т }\end{array}$ & 0,364 & 3,83 & - & 1,09 & 5,00 & 5,45 & 5,70 & 4,68 & 4,56 & 3,44 & 3,38 & 0,998 & - & 0,139 & - & - \\
\hline \multicolumn{17}{|l|}{ Содержание в хвостах, \% } \\
\hline $\mathrm{P}_{2} \mathrm{O}_{5}$ & 10,43 & 10,90 & $\mathrm{H} /$ д & 12,14 & 10,75 & 10,95 & 9,98 & 10,88 & 11,3 & 11,3 & 10,73 & 10,85 & $\mathrm{H} /$ д & & Н/д & $\mathrm{H} /$ д \\
\hline $\mathrm{ZrO}_{2}$ & 0,258 & 0,35 & Н/д & 0,30 & 0,26 & 0,30 & 0,27 & 0,28 & 0,286 & 0,277 & 0,290 & 0,328 & $\mathrm{H} /$ д & 0,251 & Н/д & $\mathrm{H} /$ д \\
\hline класса -0,071 мм & 13,5 & 25,9 & $\mathrm{H} /$ д & - & - & 52,5 & 52,4 & 53,5 & 55 & 59,6 & 63,5 & 57,7 & $\mathrm{H} /$ д & $\mathrm{H} /$ д & Н/д & H/д \\
\hline влаги & 7,2 & 9,4 & Н/д & 8,88 & 11,34 & 14,71 & 14,48 & 16,43 & 17,1 & 19,0 & 19,57 & 21,2 & $\mathrm{H} /$ д & 13,23 & $\mathrm{H} /$ д & $\mathrm{H} /$ д \\
\hline $\begin{array}{l}\text { Произведено апатитового } \\
\text { концентрата, тыс. т }\end{array}$ & 29,0 & 598,8 & - & 168,5 & 552,6 & 577,6 & 598,2 & 516,5 & 461,8 & 236,4 & 142,0 & 38,8 & - & 5,2 & - & - \\
\hline $\begin{array}{l}\text { Содержание } \mathrm{P}_{2} \mathrm{O}_{5} \\
\text { в концентрате, } \% \\
\end{array}$ & 38,3 & 38,2 & - & 38,0 & 37,88 & 37,74 & 37,79 & 37,72 & 37,26 & 37,27 & 37,4 & 37,4 & - & 36,6 & - & - \\
\hline $\begin{array}{l}\text { Извлечение } \mathrm{P}_{2} \mathrm{O}_{5} \\
\text { в концентрат, \% }\end{array}$ & 56,3 & 60,0 & - & 50,7 & 49,0 & 48,5 & 48,5 & 45,2 & 39,9 & 27,68 & 17,97 & 16,78 & - & 14,35 & - & - \\
\hline Произведено БК, тыс. т & 0,148 & 2,779 & - & 0,81 & 1,114 & 0,296 & 1,321 & 1,881 & 2,07 & 1,29 & 0,865 & 0,431 & - & 0,0295 & - & - \\
\hline $\begin{array}{l}\text { Содержание } \mathrm{ZrO}_{2} \\
\text { в БК, \% }\end{array}$ & 98,3 & 98,4 & - & 98,58 & 98,56 & 98,41 & 98,58 & 98,54 & 98,55 & 98,46 & 98,5 & 98,5 & - & 98,8 & - & - \\
\hline $\begin{array}{l}\text { Извлечение } \mathrm{ZrO}_{2} \\
\text { в БК, \% }\end{array}$ & 18,0 & 25,5 & - & 26,3 & 25,76 & 23,71 & 26,39 & 16,82 & 18,9 & 16,42 & 10,8 & 16,5 & - & 12,5 & - & - \\
\hline
\end{tabular}

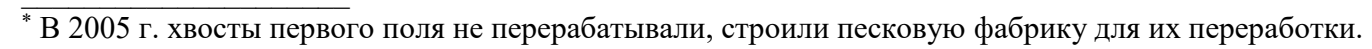

** 3а 2015, 2017-2019 гг. хвосты первого поля добывались, но не перерабатывались, а складировались в спецотвале (из-за существенного увеличения в них тонких классов и невозможности получения стандартных товарных концентратов по освоенной технологии). 
Отвод ручья Можель неперехватом фильтрационного стока, в связи с высокими затратами на проходку каналов с устройством в них противофильтрационных экранов, решили не делать. Принята схема осушения залежи хвостов, по которой сток ручья Можель аккумулируется в прудке-отстойнике и откачивается в насосную оборотного водоснабжения (HOB-1). Уровень воды в прудке поддерживается на отметке +275 м [34]. В настоящее время используется послойное снятие хвостов уступами высотой 3-8 м в субпараллельном направлении от северо-восточного к юго-западному борту карьера.

Осушение залежи осуществляется системой продольных дренажных траншей и поперечных канав со сбросом воды в зумпф карьерного водоотлива, расположенного у дамбы № 1, который углублён в морену. Поперечные канавы проходятся в хвостах глубиной 3-4 м ниже уровня поверхности подземных вод. По мере осушения прибортового массива хвостов все элементы системы осушения последовательно сдвигаются в сторону юго-западного борта карьера.

Продольная дренажная траншея имела отметки $+264 \div+260$ м (на 1 января 2002 г.) с уклоном в сторону водоприёмного зумпфа. Ширина траншеи $30-40$ м, длина 340 м. Станция водоотлива откачивает 800-1300 м³/ч. Содержание взвешенных частиц в воде системы водоотлива до 9 г/л, что выводит из работы насосы марки «Д 200 х 90» и «Д 800 х 56», рассчитанные на откачку чистой воды. Сброс воды производится на рельеф Южного борта второго поля хвостохранилища из трубопровода, проложенного по гребню дамбы № 1.

Выемка водонасыщенных линз смёрзшихся шламистых песков в подошве уступа приводит к просадке ходовой тележки экскаватора. После извлечения экскаватора линзу вырезают бульдозером, а выемку засыпают сухим крупным песком. Помимо экскаваторов ЭКГ-8И и автосамосвалов 110-136 т грузоподъёмности при подготовке и отработке месторождения большая роль отводится вспомогательному оборудованию, которое включает бульдозеры ДЭТ-250 и Д-355, а также строительные экскаваторы типа ЭО и УБ с ковшами вместимостью до $1,5 \mathrm{~m}^{3}$.

При существующей технологии отработки с помощью вспомогательной техники создаётся сеть поперечных, а иногда и продольных дренажных «мелиоративных» канав с целью осушения залежи и сброса поверхностных вод в сторону карьерного водоотлива (в период снеготаяния и обильных дождей). Работы по созданию сети таких канав ведутся круглосуточно. Производится также зачистка зумпфов карьерного водоотлива для обеспечения устойчивой работы насосов. Хвосты с высоким водонасыщением скреперуются бульдозерами в сторону выемочного оборудования. Для наблюдения за осушением хвостов оборудована гидронаблюдательная сеть из 24 скважин. Понижение уровня грунтовых вод на разных участках составляет от 1 до 10 м.

В целом в части разработки месторождения найдены относительно эффективные способы добычи, транспортирования, усреднения, очистки хвостов от посторонних материалов и осушения ТМ. В начальный период, как уже отмечалось выше, сырье ТМ и руда коренного месторождения перерабатывались раздельно во времени (две декады руда и одна декада в месяц хвосты) на одних и тех же производственных обогатительных площадях с раздельным учетом технологических и экономических показателей. Причем затраты на обогатительный передел распределялись между разными видами сырья (рудой и хвостами) пропорционально переработанным объемам, т. е. весовым методом. Затем, в 2004-2005 гг., в связи с 
увеличением спроса на железорудный концентрат хвосты практически не перерабатывались (переработка осуществлялась не более месяца в год), с мая 2006 г. хвосты перерабатывались совместно с рудами коренного месторождения по общей технологической схеме, что практически исключает возможность определения технико-экономических показателей по их использованию, а следовательно, и дифференцированную оценку экономической эффективности их промышленного использования в этот период.

С июля 2007 г. организована переработка хвостов ТМ на вновь построенной обогатительной песковой фабрике, которую в перспективе планируется использовать для переработки фосфатных апатит-штаффелитовых руд подготавливаемого к эксплуатации месторождения. С 2008 г. на предприятии в полном объеме организован учет и отражение в отчете экономических параметров производства на ПФ апатитового и бадделеитового концентратов с учетом затрат на доводку чернового БК ПФ на АБОФ. Основные отчетные экономические показатели ОАО «Ковдорский ГОК» ${ }^{86}$ в целом с выделением показателей по производству апатитового и бадделеитового концентратов из хвостов первого поля в период освоения ПФ представлены в табл. 5.2 и свидетельствуют о высокой экономической эффективности повторной переработки техногенного сырья - хвостов первого поля хвостохранилища, достигнутой коллективом ОАО «Ковдорский ГОК» [122].

Суммарные затраты по всей технологической цепочке добычи, транспортировки на обогатительную фабрику, переработки на ПФ одной тонны хвостов первого поля с учетом затрат на доработку чернового БК на АБОФ и реализации товарных апатитового и бадделеитового концентратов по отчетным данным ОАО «Ковдорский ГОК» (табл. 5.3) использовались в настоящей работе в качестве базовых для обоснования основных параметров кондиций для оконтуривания запасов хвостов, перспективных для вторичной переработки и технико-экономической оценки эффективности промышленного освоения отходов (хвостов) второго поля хвостохранилища предприятия.

86 Годовой отчет ОАО «Ковдорский ГОК» по результатам работы за 2008 год: утв. решением единств. акционера ОАО «Ковдорский ГОК» от 20 марта 2009 г. Ковдор, 2009. URL: http://www.eurochem.ru/investors-ru/rf_disclosure/annual-reports-rf/?lang=ru; Годовой отчет ОАО «Ковдорский ГОК» по результатам работы за 2009 год: утв. решением единств. акционера ОАО «Ковдорский ГОК» от 15 июня 2010 г. Ковдор, 2010. URL: http://www.eurochem.ru/investors-ru/rf_disclosure/annual-reports-rf/?lang=ru; Годовой отчет ОАО «Ковдорский ГОК» по результатам работы за 2010 год: утв. решением единств. акционера ОАО «Ковдорский ГОК» от 18 мая 2011 г. Ковдор, 2011. URL: http://www.eurochem.ru/investors-ru/rf_disclosure/annual-reports-rf/?lang=ru; Десять лет устойчивого развития: отчет об устойчивом развитии за 2010 год / «МХК “ЕвроХим"». URL: http://www.eurochem.ru/sustainability-2/social-reporting/?lang=ru; Ключ к успеху: корпоративный социальный отчет за 2008 г. / «МХК “ЕвроХим”». URL: http://www.eurochem.ru/sustainability-2/social-reporting/?lang=ru; Ключ к успеху: корпоративный социальный отчет за 2009 год/«MXK “ЕвроХим”». URL: http://www.eurochem.ru/sustainability-2/social-reporting/?lang=ru; Официальный сайт минерально-химической компании «ЕвроХим». URL: http://www.eurochem.ru/?lang=ru. 
Таблица 5.2

Основные экономические показатели ОАО «Ковдорский ГОК»

\begin{tabular}{|c|c|c|c|}
\hline Показатель & 2007 г. & 2008 г. & 2009 г. \\
\hline $\begin{array}{l}\text { Среднемесячная заработная плата одного } \\
\text { работника, тыс. руб. }\end{array}$ & 21,715 & 31,00 & 35,108 \\
\hline Затраты на 1 руб. товарной продукции, коп. & 79,69 & 40,08 & 73,36 \\
\hline Рентабельность товарной продукции, \% & 25,48 & 149,53 & 36,32 \\
\hline \multicolumn{4}{|l|}{ Себестоимость } \\
\hline $1 \mathrm{~m}^{3}$ вскрыши, руб. & 138,18 & 202,96 & 204,64 \\
\hline 1 т руды, руб. & 144,22 & 217,33 & 184,69 \\
\hline 1 т хвостов, руб. & 31,95 & 43,34 & 39,41 \\
\hline $\begin{array}{l}1 \text { т км грузооборота технологического } \\
\text { транспорта, коп. }\end{array}$ & 426,54 & 568,63 & 577,76 \\
\hline \multicolumn{4}{|l|}{ Железорудный концентрат } \\
\hline себестоимость 1 т, руб. & 828,79 & 1041,90 & 790,59 \\
\hline цена 1 т, руб. & 1088,63 & 1675,51 & 1181,94 \\
\hline рентабельность, \% & 31,35 & 60,81 & 49,50 \\
\hline \multicolumn{4}{|l|}{ Апатитовый концентрат $\left(38 \%\right.$ \% $\left.\mathrm{P}_{2} \mathrm{O}_{5}\right)$} \\
\hline себестоимость 1 т, руб. & 1425,87 & 1970,43 & 2927,72 \\
\hline из руды, руб. & 1412,38 & 1936,66 & 3189,69 \\
\hline из хвостов, руб. & 1405,17 & 1834,50 & 3131,10 \\
\hline из хвостов ПФ, руб. & 1523,55 & 2115,42 & 2044,86 \\
\hline цена 1 т, руб. & 1628,19 & 6336,55 & 4094,18 \\
\hline рентабельность, \% & 14,19 & 221,58 & 39,84 \\
\hline \multicolumn{4}{|l|}{ Бадделеитовый концентрат } \\
\hline себестоимость 1 т, руб. & 27136,83 & 25284,42 & 20921,05 \\
\hline из руды, руб. & 26855,84 & 25340,64 & 21109,74 \\
\hline из хвостов, руб. & 28762,63 & 23202,63 & 21275,44 \\
\hline из хвостов ПФ, руб. & - & 30899,44 & 19557,05 \\
\hline цена 1 т, руб. & 49978,79 & 55022,61 & 66040,50 \\
\hline рентабельность, \% & 84,17 & 117,61 & 215,67 \\
\hline \multicolumn{4}{|l|}{ Теплоэнергия } \\
\hline себестоимость 1 Гкал, руб. & 953,09 & 1187,66 & 694,02 \\
\hline цена 1 Гкал, руб. & 680,29 & 801,00 & 971,60 \\
\hline рентабельность, \% & $-28,62$ & $-32,56$ & 40,0 \\
\hline \multicolumn{4}{|l|}{ Кислород } \\
\hline себестоимость $1 \mathrm{~m}^{3}$, руб. & 113,06 & 134,15 & 123,04 \\
\hline цена $1 \mathrm{~m}^{3}$, руб. & 158,18 & 149,06 & 147,64 \\
\hline рентабельность, \% & 39,90 & 11,12 & 19,99 \\
\hline \multicolumn{4}{|l|}{$\begin{array}{l}\text { Цена единицы основных используемых ресурсов, } \\
\text { тыс. руб. }\end{array}$} \\
\hline электроэнергия, тыс. кВт·ч & 714,07 & 880,65 & $1147,65^{*}$ \\
\hline взрывчатые материалы, т & 8,89 & 12,02 & $12,99^{*}$ \\
\hline мазут, т & 5617,41 & 7035,83 & $6945,09^{*}$ \\
\hline дизтопливо, т & 15056,06 & 21347,65 & $12577,43^{*}$ \\
\hline шары, т & 20095,00 & 26606,62 & $19933,90^{*}$ \\
\hline стержни, т & 16428,51 & 23265,48 & $15337,63^{*}$ \\
\hline $\begin{array}{l}\text { Финансовый результат до налогообложения, млн } \\
\text { руб. }\end{array}$ & 2263,43 & 14159,42 & 3249,24 \\
\hline
\end{tabular}

\footnotetext{
* Данные за сентябрь.
} 
Таблища 5.3

Отчетная себестоимость продукции ПФ и суммарные затраты на добычу и переработку одной тонны хвостов первого поля хвостохранилища

\begin{tabular}{|c|c|c|c|}
\hline \multirow{2}{*}{ Статья затрат } & \multicolumn{2}{|c|}{$\begin{array}{c}\text { Себестоимость концентрата, } \\
\text { руб/т } \\
\end{array}$} & \multirow{2}{*}{$\begin{array}{c}\text { Общие затраты на } \\
1 \text { т } \\
\text { переработанных } \\
\text { хвостов, руб. } \\
\end{array}$} \\
\hline & апатитового & бадделеитового & \\
\hline Сырье & 1052,62 & 1003,40 & 43,34 \\
\hline Вспомогательные материалы & 871,17 & 723,29 & 35,86 \\
\hline В том числе реагенты & 756,73 & 392,48 & 31,13 \\
\hline Теплоэнергия & 336,59 & - & 13,83 \\
\hline Топливо технологическое & 85,77 & - & 3,52 \\
\hline Электроэнергия & 269,78 & 3842,84 & 11,40 \\
\hline \begin{tabular}{|l} 
Зарплата основных \\
производственных рабочих
\end{tabular} & 71,99 & 1977,20 & 3,12 \\
\hline Отчисления на соцстрах & 19,85 & 560,98 & 0,86 \\
\hline $\begin{array}{l}\text { Ненормируемые материалы на } \\
\text { технологию }\end{array}$ & 4,89 & 327,83 & 0,23 \\
\hline Амортизация & 93,81 & 3077,12 & 4,10 \\
\hline Содержание основных средств & 42,65 & 863,18 & 1,82 \\
\hline $\begin{array}{l}\text { Ремонт основных средств } \\
\text { (ремфонд) }\end{array}$ & 115,43 & 5433,00 & 5,18 \\
\hline Прочие цеховые расходы & 45,07 & 1230.31 & 1,95 \\
\hline $\begin{array}{l}\text { Услуги вспомогательных цехов и } \\
\text { расходы внепроизводственные }\end{array}$ & 2,91 & 1,14 & 0,12 \\
\hline Общепроизводственные расходы & 175,49 & 50,65 & 7,21 \\
\hline Общецеховые расходы & 103,52 & 32,06 & 4,26 \\
\hline Передел & 2238,92 & 18119,61 & 93,46 \\
\hline Цеховая себестоимость & 3291,54 & 19123,01 & 136,80 \\
\hline Общезаводские расходы & 497,56 & 66,44 & 20,45 \\
\hline Коммерческие расходы & 1736,02 & 968,41 & 71,41 \\
\hline Полная себестоимость & 5525,12 & 20157,86 & 228,66 \\
\hline
\end{tabular}

С вводом в ОАО «Ковдорский ГОК» новой фабрики по переработке хвостов из-за необходимости обеспечения ее сырьем на длительную перспективу было принято решение о геологическом изучении качественного состава, обогатимости и запасов хвостов второго поля в объеме, достаточном для технико-экономического обоснования эффективности их промышленного освоения [122]. Использование накопленного предприятием многолетнего положительного опыта, выявленные при этом особенности, проблемы, закономерности высокорентабельной промышленной эксплуатации ТМ с производством апатитового и бадделеитового концентратов являются необходимым условием объективной оценки возможности и эффективности повторной переработки более бедных отходов (хвостов) обогащения, накопленных на предприятии в более поздние годы, в частности заскладированных во втором поле хвостохранилища. 


\section{2. Характеристика второго поля хвостохранилища по результатам разведки}

Второе поле хвостохранилища является действующим объектом ОАО «Ковдорский ГОК». В нем размещаются и туда продолжают поступать отходы обогащения многокомпонентных руд Ковдорского месторождения, а также отходы обогащения лежалых хвостов первого поля.

Горно-геологические условия разработки ТМ второго поля сложные, месторождение сильно обводненное за счет поступления жидких хвостов (хвостохранилище действующее) и за счет ручья Можель с притоками, так как его долина служит ложем хвостохранилища. Значительную часть площади второго поля занимает отстойник оборотного водоснабжения. В настоящее время ОАО «Ковдорский ГОК» не имеет календарного графика начала освоения запасов хвостов второго поля. Имеется только несколько вариантов перспектив освоения. Во-первых, наряду с железными рудами будет проводиться добыча апатитовых руд из основного карьера (собственно Ковдорское месторождение). Во-вторых, будет продолжаться отработка запасов лежалых хвостов первого поля. В-третьих, после отработки первого поля будут вовлекаться в эксплуатацию апатит-штаффелитовые руды, содержание $\mathrm{P}_{2} \mathrm{O}_{5}$ в которых выше, чем в хвостах второго поля. И уже после освоения апатит-штаффелитовых руд наступит очередь освоения хвостов второго поля. По ориентировочным подсчетам начало этого освоения может наступить через пятнадцать - двадцать лет. За это время в хвостохранилище второго поля, которое будет оставаться действующим, будут поступать хвосты от переработки всех видов минерального сырья на ОАО «Ковдорский ГОК».

В настоящее время во втором поле размещено 206,33 млн т хвостов. При ежегодном объеме поступления хвостов в 8-9 млн т через двадцать лет их объем увеличится на 160-180 млн т. Абсолютная отметка разделительно-ограждающей дамбы № 1 составляет +291 м, а отметка дамбы № 4 равна 282-285 м. Таким образом, без большой реконструкции возможно увеличить высоту дамбы на 7-8 м, но и этого объема хвостохранилища будет недостаточно, поэтому потребуется вовлечение в эксплуатацию емкости первого поля, которое может быть заполнено на величину вынутых промышленных запасов, т. е. на 60-65 млн т. На время заполнения первого поля возможна будет и отработка запасов второго поля, так как единые правила безопасности запрещают организацию добычи на действующих хвостохранилищах. Но отработку запасов второго поля можно будет проводить только в течение семи - восьми лет при современном количестве сбрасываемых хвостов в первое поле. Поэтому с учетом долговременной добычи руды на основном месторождении может возникнуть вопрос об организации третьего поля хвостохранилища.

Таким образом, перспектива освоения лежалых хвостов второго поля требует уже в настоящее время взаимной увязки объемов поступления новых хвостов, возможных сроков заполнения первого и второго полей хвостохранилища с решением необходимых технических вопросов. При освоении запасов второго поля обязательно потребуется полностью ликвидировать отстойник (прудок) оборотного водоснабжения и решить проблему осушения и водоотлива до начала производства горных работ. Из-за 
сложностей перспективы освоения второго поля нецелесообразно в настоящее время намечать четкие границы будущего карьера.

В отличие от системы вскрытия на первом поле (от дамбы № 1), запасы второго поля целесообразно начинать вскрывать и отрабатывать от существующей автодороги к дамбе № 1, где сосредоточены запасы верхних горизонтов $(+285$ м,+279 м,+273 м). В этом случае будет наименьшее плечо откатки и хвосты на этих горизонтах будут в значительной мере обезвожены, а времени на их отработку будет достаточно для полного удаления воды из отстойника. Высота добычного уступа принимается равной 6 м, ширина и площадь рабочей площадки рассчитывается при проектировании будущего карьера в зависимости от выемочного и транспортного оборудования. Угол откоса рабочего уступа принимается в среднем равным $40^{\circ}$. При геологотехнологическом картировании по содержанию $\mathrm{P}_{2} \mathrm{O}_{5}$ и фракции -0,071 мм было выделено три технологических сорта, два из которых, I и II, будут использоваться для промышленной переработки, а III сорт не будет поступать на обогащение. Предположительно этот вид хвостов будет вывозиться из карьера второго поля и размещаться в отработанном пространстве первого поля, т. е. эта часть хвостов будет представлять собой внутреннюю вскрышу. На основании определенных физико-механических свойств хвостов, несущей способности (прочности) поверхности отработка хвостов возможна с использованием экскаваторов цикличного действия (гидроэкскаваторов с оборудованием обратная лопата) и автомобильного карьерного транспорта грузоподъемностью от 100 т и выше. При подходе к конечным границам, особенно к ограждающим дамбам, уступы целесообразно сдваивать с доведением высоты до 10 м, углы откосов неработающих уступов принять равным углу естественного откоса сухих хвостов в 34 ‥ Между сдвоенными уступами оставлять берму безопасности, равную $15 \mathrm{~m}$.

Как уже отмечалось, второе поле хвостохранилища сформировано после 1981 г. из отходов переработки магнетитовых и апатитовых руд Ковдорского месторождения. Кроме того, с 1995 г. в него размещаются и отходы переработки лежалых хвостов первого поля, из которых извлекаются $\mathrm{P}_{2} \mathrm{O}_{5}$ и $\mathrm{ZrO}_{2}$. Всего за период 1982-2007 гг. во второе поле хвостохранилища поступило 206,3 млн т

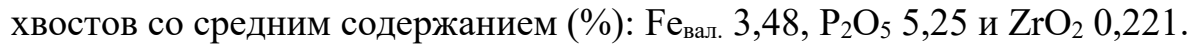

Второе поле хвостохранилища отделено от первого дамбой № 1 и представляет собой юго-восточную часть хвостохранилища. Поскольку хвостохранилище расположено в долине ручья Можель с притоками, то низкие части рельефа перегорожены дамбами: так, северо-западной границей второго поля является дамба № 1 протяженностью 950 м и с абсолютными отметками гребня $+290,0-+291,5$ м. Северо-восточной и восточной границами служит дамба № 4 длиной 3250 м и абсолютными отметками $+282-+285$ м. С юговосточной и юго-западной сторон оно ограничено естественным рельефом. Начиная с дамбы № 1 по всей дамбе № 4 проложен пульпопровод, по которому сливаются хвосты обогащения магнетитовых и апатитовых руд. Значительную часть площади поля занимает акватория бассейна оборотного водоснабжения, уровень воды в котором находится на абсолютной отметке $+276,2$ м. Глубина отстойника в наиболее глубоком месте достигает 16,6 м. Посередине акватории пруда-отстойника (бассейна оборотного водоснабжения) располагается водоспускной колодец ВК-3, по которому осветленная вода поступает в 
гидросистему вторичного отстойника. Общая площадь второго поля хвостохранилища 667,8 га, длина 4,0 км, ширина 2,5 км.

Ложем хвостохранилища служит неровная поверхность погребенного рельефа долины ручья Можель и его притоков с углом падения склонов до 5-7 ${ }^{\circ}$, местами до $10-12^{\circ}$. Заполнение чаши хвостохранилища проходило без предварительной расчистки площади и вырубки леса. Поверхность залежи относительно ровная, плоская, с небольшим уклоном на юго-восток, в сторону водной акватории. Форма залежи хвостов линзо-пластообразная. Мощность ее, определенная по разнице абсолютных отметок погребенного рельефа (235-280 м) и поверхности толщи (275-286 м), варьирует от долей метра и первых метров у юго-западного края до 38-45 м у северо-восточного.

Хвосты мокрой магнитной сепарации и апатитовой флотации представлены тонкоизмельченным песчаным материалом, где содержание фракции крупнее 0,071 мм в рядовых пробах колеблется от 4,1 до 96,8\%. Обработка результатов гранулометрического анализа рядовых проб показала, что распределение тонких частиц (менее 0,071 мм) по горизонтам отработки носит закономерный характер, количество их возрастает с глубиной (табл. 5.4). Причем возрастание содержания тонких частиц идет не за счет фракции $-0,071+$ 0,044 мм, а за счет фракции менее 0,044 мм. Изменение этой закономерности на горизонте +285 м объясняется непосредственной близостью территории этого горизонта к месту слива, а на горизонте 237-231 м тем, что здесь подстилающей хвосты толщей является не только морена, но и мелко-среднезернистые пылеватые аллювиальные пески долины ручья Можель, которые при сливе хвостов размывались и перемешивались с ними.

Таблий 5.4

Распределение средневзвешенного содержания тонких частиц по горизонтам отработки

\begin{tabular}{|c|c|c|c|c|}
\hline $\begin{array}{c}\text { Горизонт } \\
\text { отработки, м } \\
\text { абс. }\end{array}$ & $\begin{array}{c}\text { менее } 0,071 \\
\text { мм }\end{array}$ & $\begin{array}{c}-0,071+0,044 \\
\text { мм }\end{array}$ & $\begin{array}{c}\text { \% от общего } \\
\text { количества тонких } \\
\text { частиц }\end{array}$ & $\begin{array}{c}-0,044 \\
\text { мм }\end{array}$ \\
\hline+285 & 7,00 & 3,27 & 47 & 3,73 \\
\hline $285-279$ & 9,71 & 4,75 & 49 & 4,96 \\
\hline $279-273$ & 17,68 & 7,96 & 45 & 9,72 \\
\hline $273-267$ & 25,56 & 10,65 & 42 & 14,91 \\
\hline $267-261$ & 30,48 & 11,80 & 39 & 18,68 \\
\hline $261-255$ & 37,37 & 13,30 & 36 & 24,07 \\
\hline $255-249$ & 48,72 & 15,13 & 31 & 33,59 \\
\hline $249-243$ & 62,51 & 16,61 & 27 & 45,90 \\
\hline $243-267$ & 68,41 & 17,87 & 26 & 50,54 \\
\hline $237-231$ & 69,30 & 21,64 & 31 & 47,66 \\
\hline
\end{tabular}

Распределение тонких частиц внутри горизонтов также неравномерное. Нарастание их содержания идет от северо-восточной границы хвостохранилища к прудку-отстойнику и по мере удаления от мест слива. В целом общее содержание 
частиц менее 0,071 мм во втором поле хвостохранилища (в разведанной части) меньше, чем в первом, особенно в верхней его части (табл. 5.5).

Средневзвешенное содержание частиц менее 0,071 мм по слоям на первом и втором полях хвостохранилища

\begin{tabular}{|c|c|c|c|}
\hline \multirow{2}{*}{$\begin{array}{c}\text { Горизонт } \\
\text { отработки, м } \\
\text { абс. }\end{array}$} & \multicolumn{3}{|c|}{ Средневзвешенное содержание частиц менее 0,071 мм, \% } \\
\cline { 2 - 3 } & $\begin{array}{c}\text { юго-восточный } \\
\text { участок }\end{array}$ & $\begin{array}{c}\text { второе } \\
\text { поле }\end{array}$ \\
\hline+285 & 42,31 & 40,55 & 7,00 \\
\hline $285-279$ & 46,13 & 56,49 & 9,71 \\
\hline $279-273$ & 53,28 & 62,66 & 17,68 \\
\hline $273-267$ & 51,54 & 63,81 & 25,56 \\
\hline $267-261$ & 42,79 & - & 30,48 \\
\hline $261-255$ & 37,00 & - & 37,37 \\
\hline-255 & 29,44 & - & 57,14 \\
\hline
\end{tabular}

Это объясняется тем, что площадь разведочных работ второго поля расположена ближе к месту слива хвостов, чем площадь первого поля, кроме того, пруд-отстойник первого поля частично был осушен (с 1971 г. уже заполнялась чаша второго поля) и вовлечен в разведку, а нарастание содержания частиц менее 0,071 мм идет в сторону прудков-отстойников. По содержанию частиц менее 2 мм хвосты можно классифицировать как крупную супесь. Консистенция их по площади хвостохранилища неоднородная; на северовосточном фланге до горизонтали +277 м, а на юго-восточном до уреза воды прудка-отстойника (при зимнем сливе) плотная, но по мере продвижения к прудку-отстойнику она становится более обводненной, разжиженной. Кроме того, в толще плотных хвостов по направлению к прудку-отстойнику появляются линзы сильно обводненных разжиженных хвостов (плывунов) мощностью от 4,1 до 13,6 м. Естественная влажность хвостов изменяется в довольно широком интервале от 4,0 до $30 \%$, в среднем составляя $16,7 \%$.

Объемный вес хвостов, определенный лабораторным методом, составил в среднем 1,75 т/м³ «методом кольца» в среднем 1,76 т/м ${ }^{3}$, а по полевым испытаниям при работах по определению устойчивости бортов карьера был получен объемный вес $1,74 \mathrm{~T} / \mathrm{m}^{3}$. Для подсчета запасов второго поля принимается объемный вес 1,75 т/м ${ }^{3}$, при подсчете запасов первого поля был использован вес $1,74 \mathrm{~T} / \mathrm{m}^{3}$. Насыпной объемный вес в рыхлом состоянии в среднем составляет 1,43 т/м ${ }^{3}$, при колебаниях — от 0,96 до 1,68 т/м ${ }^{3}$. Минеральный состав хвостов, как показало его изучение по предварительным технологическим пробам, отличается относительным постоянством. Данные минерального состава по МТП приведены в табл. 5.6. 
Минеральный состав проб хвостов

\begin{tabular}{|c|c|c|c|c|c|c|r|}
\hline \multirow{2}{*}{$\begin{array}{c}\text { Номер } \\
\text { пробы }\end{array}$} & \multicolumn{7}{|c|}{ Содержание минералов, вес. \% } \\
\cline { 2 - 8 } & апатит & магнетит & карбонат & форстерит & флогопит & прочие $^{*}$ & сумма \\
\hline МТП-1 & 10,8 & 3,2 & 25,0 & 45,0 & 10,0 & 6,0 & 100,0 \\
\hline МТП-2 & 10,2 & 2,8 & 24,0 & 45,5 & 13,0 & 4,5 & 100,0 \\
\hline МТП-3 & 11,2 & 1,7 & 27,5 & 42,0 & 14,0 & 3,6 & 100,0 \\
\hline МТП-4 & 10,2 & 2,8 & 25,5 & 45,0 & 12,5 & 4,0 & 100,0 \\
\hline МТП-5 & 12,0 & 3,0 & 24,0 & 43,0 & 15,0 & 3,0 & 100,0 \\
\hline МТП-6 & 13,4 & 2,0 & 27,0 & 39,5 & 15,5 & 2,6 & 100,0 \\
\hline МТП-7 & 12,0 & 2,7 & 25,0 & 42,0 & 15,0 & 3,3 & 100,0 \\
\hline
\end{tabular}

* В графу «Прочие» вошли второстепенные и акцессорные минералы: эгирин-диопсид, клиногумит, сульфиды, серпентин, ильменит, бадделеит, циркон, циркелит.

Как видно из табл. 5.6, в целом вариации минерального состава хвостов незначительные: на $80 \%$ они сложены оливином (форстеритом), флогопитом и карбонатом. Содержание апатита варьирует от 10,2 до 13,4 \%, причем его содержание зависит от крупности хвостов. Так, в пробах МТП 3 и 6, где содержание фракции -0,071 мм составляет 73,11 и 75,79 \%, апатит содержится в количестве $11,2-13,4 \%$, а в более крупных пробах МТП 2 и 4 в количестве $10,2 \%$. Такая же закономерность прослеживается и для карбонатов, а вот количество магнетита и форстерита больше в более крупнозернистых пробах.

В таблице 5.7 приведено сопоставление содержания минералов в зависимости от гранулометрического состава хвостов. Апатит во всех пробах встречается в основном в виде хорошо раскрытых зерен без пленок и примазок, и только в классах крупнее 0,2 мм появляются его бедные и средние сростки преимущественно с форстеритом и карбонатом, что снижает степень раскрытия зерен апатита.

Таблица 5.7

Содержание минералов в зависимости от гранулометрического состава хвостов

\begin{tabular}{|c|c|c|c|c|c|}
\hline \multirow{2}{*}{ № пробы } & \multirow{2}{*}{\begin{tabular}{c} 
Содержание \\
частиц \\
\cline { 4 - 6 }
\end{tabular}} & \multicolumn{4}{|c|}{ Содержание минералов, \% } \\
\cline { 3 - 6 } & ап1 мм, \% & апатит & магнетит & карбонат & форстерит \\
\hline МТП-3 & 73,11 & 11,2 & 1,7 & 27,5 & 42,0 \\
\hline МТП-6 & 75,79 & 13,4 & 2,0 & 27,0 & 39,5 \\
\hline МТП-2 & 16,87 & 10,2 & 2,8 & 24,0 & 45,5 \\
\hline МТП-4 & 22,73 & 10,2 & 2,8 & 25,5 & 45,0 \\
\hline
\end{tabular}

Магнетит, в основном, находится в сростках, от богатых (более 56,0\% магнетита в сростке) до средних (10-45 \% магнетита) и бедных (менее 5-10\% магнетита). Наиболее часто встречаются сростки магнетита с форстеритом, флогопитом, карбонатом, клиногумитом. Поверхность зерен магнетита в целом не претерпела сильных изменений, но на некоторых зернах заметны охристые пленки окисления. Кроме первичного магнетита в силикатных минералах хвостов широко 
распространен вторичный магнетит, образующий тонкую пылевидную вкрапленность или штриховидные выделения в форстерите, флогопите, клиногумите.

Зерна форстерита чистые, без пленок и примазок, с включениями вторичного магнетита.

Флогопит, главным образом, зеленый, зачастую хлоритизированный, реже встречаются бурый тетрафлогопит и темно-бурый железистый.

Карбонат - кальцит и доломит встречаются в виде прозрачных ромбоэдрических обломков кристаллов. Мутность многих их них объясняется наличием многочисленных газовых и газово-жидких включений.

Сопоставление минерального состава хвостов первого и второго полей (табл. 5.8) показало, что хвосты второго поля хвостохранилища в сравнении с хвостами первого идентичны по минеральному составу, но более бедные по содержанию апатита и содержат большее количество магнетита, форстерита, флогопита. Карбонаты в хвостах обоих полей находятся в равных количествах.

Таблица 5.8

Минеральный состав хвостов первого и второго полей хвостохранилища

\begin{tabular}{|l|c|c|c|c|c|}
\hline \multirow{2}{*}{ Содержание } & \multicolumn{5}{|c|}{ Содержание минералов, \% } \\
\cline { 2 - 6 } & апатит & магнетит & карбонат & форстерит & флогопит \\
\hline От-до & $19,0-30,3$ & $1,1-2,9$ & $19,0-31,0$ & $26,9-48,0$ & $3,5-9,1$ \\
\hline Среднее & 23,9 & 1,5 & 25,2 & 36,3 & 6,3 \\
\hline \multicolumn{7}{|c|}{ Второе поле } \\
\hline От-до & $10,2-13,4$ & $1,7-3,2$ & $24,0-27,5$ & $39,5-45,5$ & $10,0-15,5$ \\
\hline Среднее & 11,4 & 2,6 & 25,4 & 43,1 & 13,6 \\
\hline
\end{tabular}

Кроме того, содержание минералов в хвостах второго поля колеблется в более узком диапазоне, чем в хвостах первого поля. Таким образом, минеральный состав хвостов обогащения второго поля хвостохранилища довольно выдержанный. Как следствие, химический состав их колеблется также в небольших интервалах (табл. 5.9).

Таблища 5.9

Колебание значений содержания компонентов в хвостах

\begin{tabular}{|l|c|c|c|c|}
\hline \multirow{2}{*}{$\begin{array}{c}\text { Химический } \\
\text { компонент }\end{array}$} & \multicolumn{3}{|c|}{ Содержание, \% } & \multirow{2}{*}{$\begin{array}{c}\text { \% от общего } \\
\text { количества } \\
\text { определений }\end{array}$} \\
\cline { 2 - 4 } & 16,54 & 31,18 & $21-27$ & 91 \\
\hline $\mathrm{SiO}$ & & 27,22 & $18-24$ & 92 \\
\hline $\mathrm{CaO}$ & 15,69 & $21-28$ & 90 \\
\hline $\mathrm{MgO}$ & 18,61 & 30,49 & $21-28$ & 90 \\
\hline $\mathrm{Fe}_{\text {вал. }}$ & 3,38 & 8,25 & $3,5-5,0$ & 93 \\
\hline $\mathrm{Fe}_{\text {магн. }}$ & 0,47 & 3,86 & $0,5-1,7$ & 89 \\
\hline $\mathrm{P}_{2} \mathrm{O}_{5}$ & 2,16 & 7,88 & $3-7$ & 91 \\
\hline $\mathrm{ZrO}_{2}$ & 0,11 & 0,64 & $0,15-0,27$ & 88 \\
\hline $\mathrm{CO}_{2}$ & 6,24 & 20,63 & $8-14$ & \\
\hline
\end{tabular}


Сопоставление средневзвешенных содержаний основных химических компонентов в хвостах первого и второго полей хвостохранилища показало, что значительные изменения химического состава хвостов произошло только по содержанию $\mathrm{P}_{2} \mathrm{O}_{5}$ и $\mathrm{ZrO}_{2}$. В хвостах второго поля содержание $\mathrm{P}_{2} \mathrm{O}_{5}$ понизилось с 8-12 до 3-6 \% (на $55 \%$ относительно), a $\mathrm{ZrO}_{2}$ - с 0,24-0,3 до 0,19-0,25\% (20\% относительно), что связано с извлечением из руд Ковдорского месторождения апатита и бадделеита после запуска АБОФ. Распределение химических компонентов в толще хвостов второго поля в зависимости от глубины залегания различно (табл. 5.10). Наиболее стабильным распределением отличается содержание $\mathrm{CO}_{2}$, в то время как содержание $\mathrm{P}_{2} \mathrm{O}_{5}$ возрастает с глубиной почти в два раза, а содержание $\mathrm{Fe}_{\text {вал., }} \mathrm{MgO}, \mathrm{ZrO}_{2}$ и $\mathrm{SiO}_{2}$ снижается. Также с глубиной возрастает содержание $\mathrm{CaO}$.

Таблича 5.10

Средневзвешенные содержания компонентов по горизонтам отработки второго поля хвостохранилища

\begin{tabular}{|c|c|c|r|c|c|c|c|c|}
\hline $\begin{array}{c}\text { Горизонт } \\
\text { отработки, } \\
\text { м абс. }\end{array}$ & $\mathrm{P}_{2} \mathrm{O}_{5}$ & $\mathrm{Fe}_{\text {вал. }}$ & $\mathrm{Fe}_{\text {магн. }}$ & $\mathrm{CO}_{2}$ & $\mathrm{SiO}_{2}$ & $\mathrm{CaO}$ & $\mathrm{MgO}$ & $\mathrm{ZrO}_{2}$ \\
\hline+285 & 3,44 & 5,39 & 1,69 & 11,46 & 24,87 & 19,56 & 26,79 & 0,25 \\
\hline $285-279$ & 3,98 & 5,12 & 1,65 & 11,22 & 24,78 & 19,60 & 27,04 & 0,25 \\
\hline $279-273$ & 3,76 & 4,54 & 1,29 & 11,76 & 24,65 & 19,88 & 26,38 & 0,21 \\
\hline $273-267$ & 4,08 & 4,34 & 1,16 & 11,69 & 24,33 & 20,17 & 25,53 & 0,21 \\
\hline $267-261$ & 4,32 & 4,19 & 1,04 & 11,73 & 24,28 & 20,56 & 24,75 & 0,20 \\
\hline $261-255$ & 4,70 & 4,08 & 0,99 & 11,93 & 23,91 & 20,97 & 24,12 & 0,21 \\
\hline $255-249$ & 5,14 & 4,00 & 0,90 & 11,87 & 23,52 & 21,46 & 23,27 & 0,21 \\
\hline $249-243$ & 5,56 & 3,94 & 0,82 & 12,00 & 23,00 & 22,17 & 22,34 & 0,21 \\
\hline $243-267$ & 5,97 & 3,90 & 0,83 & 12,08 & 22,59 & 22,53 & 21,89 & 0,20 \\
\hline $237-231$ & 6,20 & 4,00 & 0,95 & 11,80 & 22,91 & 21,52 & 22,09 & 0,19 \\
\hline
\end{tabular}

Полученные данные о содержании компонентов и их распределении в хвостах обогащения второго поля позволяют сделать следующие выводы: хвосты обогащения по своему минеральному, химическому и гранулометрическому составам аналогичны хвостам первого поля; содержания минералов в хвостах второго поля колеблются в более узких интервалах, чем в хвостах первого поля; содержание основных компонентов $\mathrm{P}_{2} \mathrm{O}_{5}$ и $\mathrm{ZrO}_{2}$ в хвостах второго поля ниже, чем в первом поле: $\mathrm{P}_{2} \mathrm{O}_{5}-3,6 \%$ (второе поле) против 8-12 \% (первое поле); $\mathrm{ZrO}_{2}-0,19-0,25 \%$ (второе поле) против 0,24-0,31 \% (первое

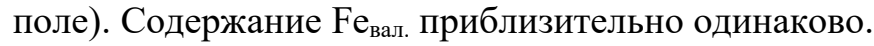

Таким образом, учитывая схожесть минерального, химического и гранулометрического составов и опыт переработки хвостов первого поля, накопленные отходы обогащения второго поля представляют интерес для повторной переработки и комплексной утилизации, во всяком случае, наиболее богатая их часть. 


\section{3. Технологические исследования обогатимости отходов второго поля хвостохранилища}

Технологические испытания хвостов обогащения проводились с целью изучения их минералого-технологических особенностей, разработки технологической схемы и определения показателей обогащения хвостов второго поля хвостохранилища при получении апатитового, магнетитового и чернового бадделеитового концентратов и проходили в два этапа. На первом этапе проводились испытания семи МТП. По результатам лабораторного исследования рядовых проб, отобранных по слоям из керна пройденных скважин, было выделено три технологических сорта: I сорт - содержание $\mathrm{P}_{2} \mathrm{O}_{5}$ $>3 \%$, содержание фракции $-0,071 \mathrm{мm}<56 \%$; II сорт $-\mathrm{P}_{2} \mathrm{O}_{5}>3 \%$, фракции $-0,071$ мм $>56 \%$ и III сорт $-\mathrm{P}_{2} \mathrm{O}_{5}<3 \%$.

Формирование проб МТП было проведено по этим выделенным технологическим сортам: две пробы были отобраны из I сорта (пробы 2, 5), две пробы - из II сорта (пробы 3, 6), две пробы из смеси I и II сортов (пробы 4, 7) и одна проба из смеси I и III сортов (проба 1). Испытания проб МТП показали, что химические характеристики, несмотря на столь значительные колебания в крупности исследуемых проб, не имеют существенных различий, что свидетельствует о высокой степени устойчивости технологических процессов извлечения соответствующих минералов.

Технология получения магнетитового концентрата основана на магнитных

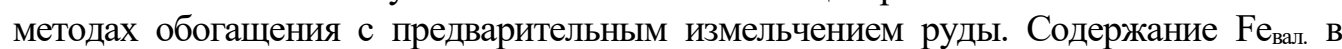
железорудных концентратах составляет 60,2-60,8 \%. Исключение - концентрат, полученный из МТП-6 (содержание фракции - 0,050 мм 56,7 \%, в остальных пробах - 3,0-48,6 \%), он содержит 63,4 \%. Возможно повышение содержания в

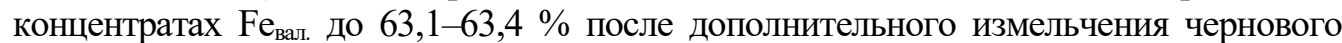
магнетитового концентрата до крупности класса $-0,071$ мм - $70 \%$. Выход магнетитового концентрата из всех проб составил $0,6-1,7 \%$.

Технология получения апатитового концентрата основана на предварительном обесшламливании (сгущении) немагнитной фракции с последующей флотацией апатита (основная флотация и две - три перечистных операции). Показатели обогащения апатита из проб МТП-2, 4, 5, 7 близки. Выход шламов составил 3-8 \%. Получен апатитовый концентрат с содержанием 38,09-38,69 $\% \mathrm{P}_{2} \mathrm{O}_{5}$ при извлечении 25,6-31,6 \% $\mathrm{P}_{2} \mathrm{O}_{5}$. Из проб МТП-3 и 6, выделен апатитсодержащий продукт с содержанием $15,9-24,0$ \% $\mathrm{P}_{2} \mathrm{O}_{5}$. Флотация проводилась на лабораторных флотомашинах 237-ФЛ-А. В качестве реагентов использовались применяемые в настоящее время при флотации апатита на АБОФ ОАО «Ковдорский ГОК» регулятор среды - сода, депрессор, жидкое стекло; собиратель - жидкие кислоты таловых масел (ЖКТМ); модификатор - вспениватель - «Неонол $+\mathrm{M}_{246}$ ».

Технология получения БК основана на применении гравитационных методов обогащения (классификация, концентрация на столах). Черновой БК, выделенный из пробы МТП-2 (0,25 \% $\left.\mathrm{ZrO}_{2}\right)$, содержит 59,6 \% $\mathrm{ZrO}_{2}$ при извлечении $25 \%$ из хвостов апатитовой флотации.

В результате проведенных технологических испытаний по обогащению проб хвостов второго поля на МТП была рекомендована технологическая схема для проведения опытно-промышленных испытаний (рис. 5.1, 5.2). 


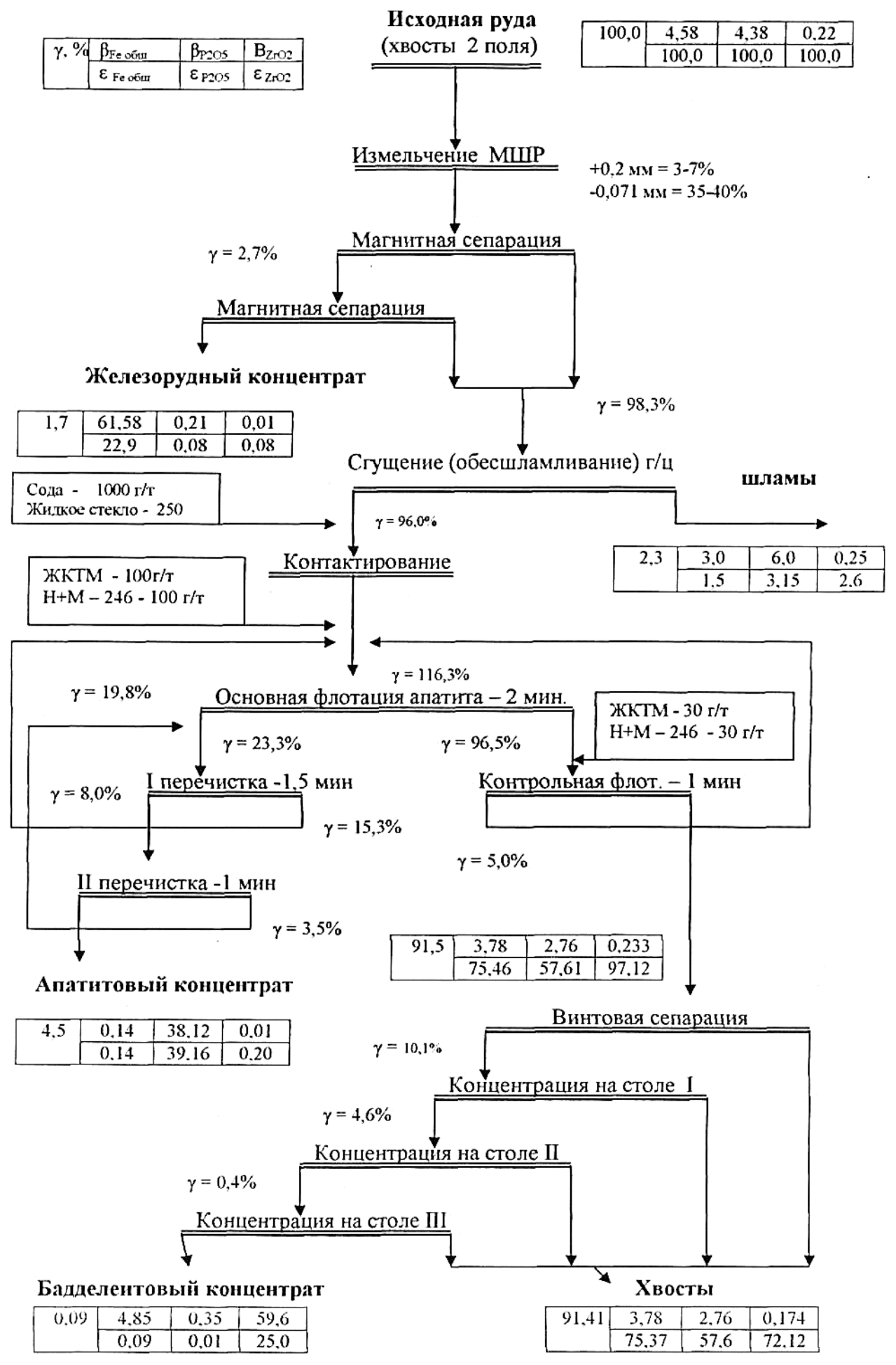

Рис. 5.1. Технологическая схема обогащения хвостов второго поля ОАО «Ковдорский ГОК» для опытно-промышленных испытаний 


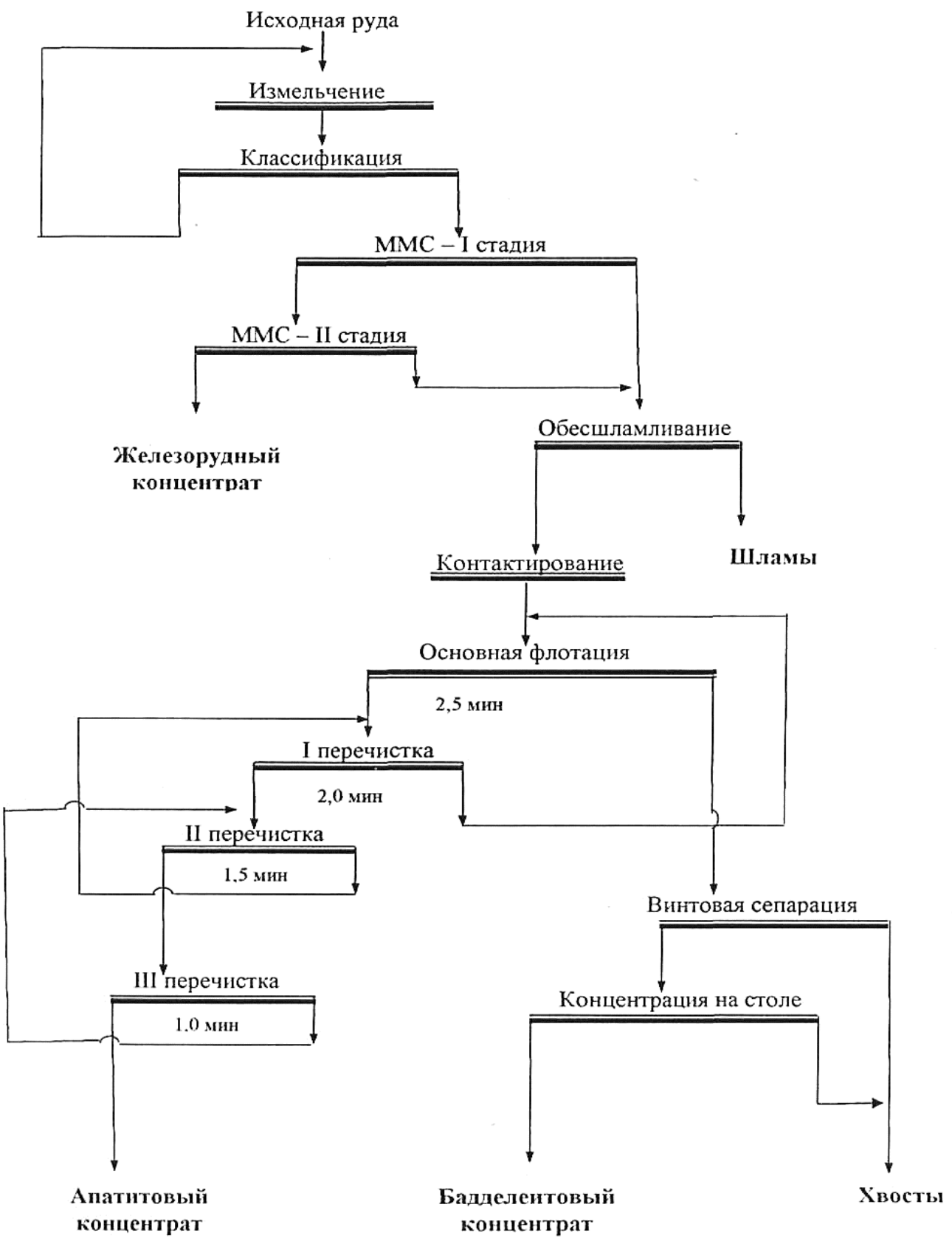

Рис. 5.2. Рекомендованная технологическая схема обогащения хвостов второго поля хвостохранилища ОАО «Ковдорский ГОК»

Получение качественного железорудного концентрата возможно при условии проведения дополнительного более тонкого измельчения с последующей магнитной сепарацией. Получение апатитового концентрата включает: обесшламливание немагнитной фракции сепарации с выводом шламов из процесса, обработку пульпы реагентами и последующую флотацию 
(основная флотация и три перечистных операции). Выход кондиционного апатитового концентрата составляет 3,2-3,8 \% при извлечении $27-29 \% \mathrm{P}_{2} \mathrm{O}_{5}$.

\section{4. Расчет параметров кондиций для условий техногенного месторождения в рамках второго поля хвостохранилища}

В соответствии с изложенными в разделе 4.4 теоретическими и практическими особенностями обоснования основных параметров кондиций на многокомпонентное минеральное сырье, каковым являются отходы (хвосты) как первого, так и второго поля хвостохранилища ОАО «Ковдорский ГОК», необходимо обосновать минимальное промышленное содержание основного ценного компонента $\mathrm{P}_{2} \mathrm{O}_{5}$ и в качестве бортовых содержаний предельные или браковочные содержания каждого из извлекаемых в товарную продукцию полезных компонентов. Кроме того, необходимо рассчитать коэффициенты для приведения содержаний бадделеита и железа к содержанию «основного условного компонента» - пентоксиду фосфора. Причем, по мнению авторов, логичнее и правильнее определять общее содержание полезных компонентов в пересчете на содержание основного условного компонента в каждом подсчетном блоке и сравнивать его с минимальным расчетным промышленным содержанием конкретного компонента, принятого за основной, чем определять заниженное минимальное промышленное содержание этого основного компонента при процедуре исключения стоимости остальных компонентов из общих затрат на добычу и переработку сырья.

Минимальное промышленное содержание полезного компонента определяется аналитически на основе следующего соотношения [82]:

$$
\mathrm{C}_{\min }=1003 / \text { [ЦИ (1-P)], }
$$

где $\mathrm{C}_{\min }$ - минимальное промышленное содержание полезного компонента, \%; 3 - эксплуатационные затраты на добычу и обогащение одной тонны сырья, руб.; Ц - оптовая цена (производителя) товарной продукции, получаемой при переработке одной тонны сырья, руб.; И - сквозное извлечение полезного компонента в товарную продукцию из минерального сырья, доли ед.; Р коэффициент, учитывающий разубоживание при добыче, доли ед.

Формулы для аналитического расчета бортовых или браковочных содержаний полезных компонентов для оконтуривания промышленных запасов полезного ископаемого в принципе аналогичны расчету минимального промышленного содержания, но учитывают не полные (прямые + косвенные), а только прямые затраты, непосредственно и неизбежно связанные с извлечением (производством) только конкретного ценного компонента. Величина прямых затрат на производство и реализацию каждого из ценных компонентов из отходов второго поля определена по аналогии с данными по первому полю, скорректированными в части затрат на реализацию (коммерческих расходов) в соответствии с более низкими выходами концентратов по второму полю (табл. 5.11). 
Таблица 5.11

Прямые затраты на производство и реализацию концентратов в расчете на одну тонну переработанных отходов (хвостов) второго поля хвостохранилища

\begin{tabular}{|c|c|c|c|}
\hline \multirow{2}{*}{ Показатель } & \multicolumn{3}{|c|}{ Концентрат } \\
\cline { 2 - 4 } & $\begin{array}{c}\text { железорудный } \\
\text { (из руды) }\end{array}$ & $\begin{array}{c}\text { апатитовый } \\
\text { (из хвостов) }\end{array}$ & $\begin{array}{c}\text { бадделеитовый } \\
\text { (из хвостов) }\end{array}$ \\
\hline Прямые затраты & & & 1,46 \\
\hline на производство & 6,37 & 6,63 & 0,039 \\
\hline на реализацию* & 4,51 & 21,78 & 1,50 \\
\hline Итого & 10,88 & 28,41 & \\
\hline
\end{tabular}

* Скорректированы отчетные данные первого поля с учетом меньшего выхода концентратов из хвостов второго поля хвостохранилища.

Общие (прямые + косвенные) затраты на добычу и переработку отходов (хвостов) второго поля хвостохранилища приняты по аналогии с фактическими (отчетными) затратами по первому полю в период выполнения работы в размере 228,66 руб/т, увеличенными на дополнительные прямые затраты на производство и реализацию железорудного концентрата 10,88 руб. в расчете на одну тонну отходов второго поля. Таким образом, сумма затрат на добычу и переработку одной тонны хвостов второго поля (3), принятая для расчетов, составляет 239,54 руб.

Извлечение $\mathrm{P}_{2} \mathrm{O}_{5}$ и других компонентов в стандартные концентраты принимаем по данным технологических испытаний по обогащению хвостов второго поля (приведены в результирующей таблице 5.14). Разубоживание отходов при добыче в виду незначительности в расчетах не учитываем.

Поскольку цены апатитового, бадделеитового и железорудного концентратов, реализуемых ОАО «Ковдорский ГОК» на внутреннем и внешнем рынках, изменяются в достаточно широких пределах, обоснование бортовых браковочных содержаний каждого из ценных компонентов и минимального промышленного содержания основного компонента $\left(\mathrm{P}_{2} \mathrm{O}_{5}\right)$ осуществлено (табл. 5.12) при использовании фактических минимальной, максимальной и средневзвешенной цен за время проведения работы.

Таблица 5.12

Расчетные параметры кондиций при использовании цен концентратов разного уровня

\begin{tabular}{|c|c|c|c|c|}
\hline \multirow{2}{*}{$\begin{array}{c}\text { Уровень цен } \\
\text { концентратов }\end{array}$} & \multirow{2}{*}{$\begin{array}{c}\text { Минимальное } \\
\text { промышленное } \\
\text { содержание } \mathrm{P}_{2} \mathrm{O}_{5}, \%\end{array}$} & \multicolumn{3}{|c|}{$\begin{array}{c}\text { Бортовое (браковочное) } \\
\text { содержание, } \%\end{array}$} \\
\hline & & $\mathrm{P}_{2} \mathrm{O}_{5}$ & $\mathrm{ZrO}_{2}$ & $\mathrm{Fe}_{\text {вал. }}$ \\
\hline Минимальный & 9,0 & 1,07 & 0,0144 & 3,3 \\
\hline Максимальный & 3,18 & 0,38 & 0,0100 & 0,64 \\
\hline Средневзвешенный & 5,32 & 0,63 & 0,0117 & 1,8 \\
\hline
\end{tabular}


Переводные коэффициенты содержаний $\mathrm{ZrO}_{2}$ и $\mathrm{Fe}_{\text {вал. }}$ к содержанию основного компонента $\mathrm{P}_{2} \mathrm{O}_{5}$ рассчитываются в соответствии с методическими рекомендациями ГКЗ [82] по формуле:

$$
\mathrm{K}_{i}=\bigsqcup_{i} \quad И_{i} \quad \mathrm{C}_{i} / Ц_{\mathrm{o}} \quad И_{\mathrm{o}} \mathrm{C}_{\mathrm{o}},
$$

где $\mathrm{C}_{i}$ и $\mathrm{C}_{\mathrm{o}}$-содержание $i$-го и основного компонентов в одноименных концентратах соответственно. Остальные обозначения прежние.

Рассчитанные переводные коэффициенты при разном уровне цен концентратов приведены в табл. 5.13.

Таблица 5.13

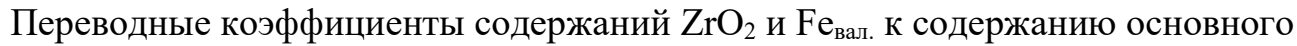
компонента $\mathrm{P}_{2} \mathrm{O}_{5}$ в отходах (хвостах) второго поля

\begin{tabular}{|l|c|c|}
\hline \multirow{2}{*}{ Уровень цен концентратов } & \multicolumn{2}{|c|}{ Переводные коэффициенты } \\
\cline { 2 - 3 } & для $\mathrm{ZrO}_{2}$ & для $\mathrm{Fe}_{\text {вал. }}$ \\
\hline Минимальный & 25,97 & 0,29 \\
\hline Максимальный & 12,29 & 0,52 \\
\hline Средневзвешенный & 18,90 & 0,32 \\
\hline
\end{tabular}

Рациональные варианты параметров кондиций применительно к категориям и технологическим сортам подсчитанных запасов отходов (хвостов) второго поля выявляются по результатам оценки экономической эффективности их промышленного освоения, выполненной ниже.

\section{5. Технико-экономический расчет эффективности промышленного освоения запасов отходов (хвостов) второго поля хвостохранилища}

В соответствии с Методическими рекомендации ГКЗ России по техникоэкономическому обоснованию кондиций для подсчета запасов месторождений твердых полезных ископаемых экономическое обоснование подсчетных параметров кондиций и оценки экономической эффективности промышленного освоения выявленных запасов [82] как природного, так и техногенного сырья основываются на принципах, рекомендованных официальным изданием Методических рекомендаций по оценке эффективности инвестиционных проектов [81].

Основными критериями при оценке экономической эффективности инвестиционных проектов являются чистый дисконтированный доход (ЧДД), индекс доходности (ИД), внутренняя норма доходности (ВНД) и срок окупаемости капиталовложений $(\mathrm{T})$. Чистый дисконтированный доход вычисляется по формуле:

$$
\text { чдд }(N P V)=\sum_{t=0}^{T}\left(Ц_{t}-3_{t}\right) \frac{1}{(1+E)^{t}}-\sum_{t=0}^{T} K_{t} \frac{1}{(1+E)^{t}} ，
$$

где Ц ${ }_{t}-$ стоимость реализованной продукции в $t$-м году; $3_{t}-$ эксплуатационные затраты в $t$-м году за вычетом амортизационных отчислений, но с учетом налога на имущество $2,2 \%$ от стоимости основных фондов и налога на прибыль (20\% 
от суммы налогооблагаемой прибыли, НДПИ при эксплуатации техногенных месторождений не применяется, что является определенным стимулом для утилизации отходов производства); $K_{t}-$ капиталовложения в $t$-м году; $E-$ ставка дисконтирования, в соответствии с [82] обычно принимается равной 10 или $15 \%$. Применительно к техногенному сырью принимаем $10 \%$.

Горизонт расчета применительно к эксплуатации месторождений зависит от принятой годовой производительности и срока отработки промышленных запасов, но рекомендуется ограничивать двадцатью годами [82]. Индекс доходности определяется как отношение суммы приведенных доходов (первая сумма в формуле для ЧДД) к величине приведенных капиталовложений (вторая сумма в формуле для ЧДД). При ЧДД больше нуля (экономически эффективный проект) величина ИД больше единицы. Внутренняя норма доходности представляет собой ту норму дисконтирования $E$, при которой ЧДД равняется нулю. Если ВНД больше величины нормы дисконтирования, инвестиционный проект имеет запас прочности при его реализации.

Срок окупаемости капиталовложений представляет собой минимальный период времени от начала реализации проекта, за пределами которого величина накопленного (кумулятивного) денежного потока (ЧДД) становится неотрицательной. Срок окупаемости определяется с использованием процедуры дисконтирования и без него.

При расчетах эффективности промышленного освоения отходов второго поля хвостохранилища годовой объем добычи и переработки отходов принят 5000 тыс. т в год, на уровне фактически достигнутого ОАО «Ковдорский ГОК» при эксплуатации первого поля. Капиталовложения при освоении отходов второго поля приняты равными первоначальной стоимости основных фондов, используемых при добыче и переработке отходов первого поля по данным предприятия. Срок строительства объектов по всей цепочке добычи и переработки отходов второго поля - три года, год освоения проектной мощности - четвертый от начала реализации проекта. Основные исходные данные и результаты расчетов сведены в табл. 5.14.

Таблица 5.14

Основные технико-экономические показатели производства

\begin{tabular}{|c|c|c|c|c|}
\hline \multirow{2}{*}{ Показатель } & \multicolumn{2}{|c|}{$\begin{array}{c}\text { Средневзвешенные } \\
\text { цены реализации }\end{array}$} & $\begin{array}{c}\text { Максимальные цены } \\
\text { реализации }\end{array}$ \\
\cline { 2 - 5 } & за год & за весь период & за год & $\begin{array}{c}\text { за весь } \\
\text { период }\end{array}$ \\
\hline 1 & 2 & 3 & 4 & 5 \\
\hline $\begin{array}{l}\text { 1. Геологические запасы, тыс. т, } \\
\text { всего }\end{array}$ & & 194286,60 & & 194286,60 \\
\hline $\begin{array}{l}\text { В том числе предварительно } \\
\text { оцененные, всего }\end{array}$ & & 115693,07 & & 115693,07 \\
\hline сорт 1 & & 86041,69 & & 86041,69 \\
\hline сорт 2 & & 23354,70 & & 23354,70 \\
\hline сорт 1+2 & & 109396,39 & & 109396,39 \\
\hline сорт 3 & 6269,68 & & 6269,68 \\
\hline
\end{tabular}


Продолжение таблицы 5.14

\begin{tabular}{|c|c|c|c|c|}
\hline 1 & 2 & 3 & 4 & 5 \\
\hline 1.2. Прогнозные ресурсы, тыс. т & & 78593,53 & & 78593,53 \\
\hline \multicolumn{5}{|l|}{$\begin{array}{l}\text { 2. Геологические запасы } \\
\text { компонентов, тыс. т, всего }\end{array}$} \\
\hline $\mathrm{P}_{2} \mathrm{O}_{5}$ & & 10200,07 & & 10200,07 \\
\hline $\mathrm{ZrO}_{2}$ & & 427,43 & & 427,43 \\
\hline $\mathrm{Fe}_{\text {вал. }}$ & & 6761,17 & & 6761,17 \\
\hline \multicolumn{5}{|l|}{ В том числе Сорт $1+2$} \\
\hline $\mathrm{P}_{2} \mathrm{O}_{5}$ & & 5032,23 & & 5032,23 \\
\hline $\mathrm{ZrO}_{2}$ & & 229,73 & & 229,73 \\
\hline $\mathrm{Fe}_{\text {вал. }}$ & & 4660,28 & & 4660,28 \\
\hline \multicolumn{5}{|l|}{$\begin{array}{l}\text { Среднее содержание в } \\
\text { геологических запасах (min - } \\
\max ), \%\end{array}$} \\
\hline $\mathrm{P}_{2} \mathrm{O}_{5}$ & & $2,76-6,35$ & & $2,76-6,35$ \\
\hline $\mathrm{ZrO}_{2}$ & & $0,20-0,23$ & & $0,20-0,23$ \\
\hline $\mathrm{Fe}_{\text {вал. }}$ & & $2,31-4,35$ & & $2,31-4,35$ \\
\hline 3. Промышленные запасы, тыс. т & & 109396,39 & & 109396,39 \\
\hline \multicolumn{5}{|l|}{$\begin{array}{l}\text { 4. Промышленные запасы } \\
\text { компонентов, тыс. т }\end{array}$} \\
\hline $\mathrm{P}_{2} \mathrm{O}_{5}$ & & 5032,23 & & 5032,23 \\
\hline $\mathrm{ZrO}_{2}$ & & 229,73 & & 229,73 \\
\hline $\mathrm{Fe}_{\text {вал. }}$ & & 4660,28 & & 4660,28 \\
\hline \multicolumn{5}{|l|}{$\begin{array}{l}\text { 5. Среднее содержание в } \\
\text { промышленных запасах, \% }\end{array}$} \\
\hline $\mathrm{P}_{2} \mathrm{O}_{5}$ & & 4,60 & & 4,60 \\
\hline $\mathrm{ZrO}_{2}$ & & 0,21 & & 0,21 \\
\hline $\mathrm{Fe}_{\text {вал. }}$ & & 4,26 & & 4,26 \\
\hline 6. Потери, \% & & - & & - \\
\hline 7. Разубоживание, $\%$ & & - & & - \\
\hline 8. Эксплуатационные запасы, тыс. т & & 109396,39 & & 109396,39 \\
\hline \multicolumn{5}{|l|}{$\begin{array}{l}\text { 9. Эксплуатационные запасы } \\
\text { компонентов, тыс. т }\end{array}$} \\
\hline $\mathrm{P}_{2} \mathrm{O}_{5}$ & & 5032,23 & & 5032,23 \\
\hline $\mathrm{ZrO}_{2}$ & & 229,73 & & 229,73 \\
\hline $\mathrm{Fe}_{\text {вал. }}$ & & 4660,28 & & 4660,28 \\
\hline \multicolumn{5}{|l|}{$\begin{array}{l}\text { 10. Среднее содержание в } \\
\text { эксплуатационных запасах, \% }\end{array}$} \\
\hline $\mathrm{P}_{2} \mathrm{O}_{5}$ & & 4,60 & & 4,60 \\
\hline $\mathrm{ZrO}_{2}$ & & 0,21 & & 0,21 \\
\hline $\mathrm{Fe}_{\text {вал. }}$ & & 4,26 & & 4,26 \\
\hline $\begin{array}{l}\text { 11. Срок обеспеченности } \\
\text { предприятия запасами, лет }\end{array}$ & & 21,9 & & 21,9 \\
\hline
\end{tabular}


Продолжение таблищы 5.14

\begin{tabular}{|c|c|c|c|c|}
\hline 1 & 2 & 3 & 4 & 5 \\
\hline 12. Горизонт расчета, лет & & 20 & & 20 \\
\hline $\begin{array}{l}\text { 13. Год выхода предприятия на } \\
\text { полную мощность, год }\end{array}$ & & Четвертый & & Четвертый \\
\hline $\begin{array}{l}\text { 14. Производственная мощность } \\
\text { предприятия по руде, тыс. т }\end{array}$ & 5000 & & 5000 & \\
\hline \multicolumn{5}{|l|}{ 15. То же по концентратам, тыс. т } \\
\hline апатитовый $\left(38 \%\right.$ P $\left.\mathrm{P}_{2} \mathrm{O}_{5}\right)$ & 163,4 & & 163,4 & \\
\hline бадделеитовый $(98$ \% Z ZrO & 1,939 & & 1,939 & \\
\hline железорудный (58 \% Fe) & 110,17 & & 110,17 & \\
\hline \multicolumn{5}{|l|}{ 16. Коэффициент вскрыши, м³/т } \\
\hline \multicolumn{5}{|l|}{ 17. Горная масса, тыс. т (м³) } \\
\hline \multicolumn{5}{|l|}{ 18. Показатели обогащения } \\
\hline \multicolumn{5}{|l|}{ выход концентратов, \% } \\
\hline апатитового & 3,27 & & 3,27 & \\
\hline бадделеитового & 0,0388 & & 0,0388 & \\
\hline железорудного & 2,2 & & 2,2 & \\
\hline \multicolumn{5}{|l|}{ извлечение в концентрат, \% } \\
\hline $\mathrm{P}_{2} \mathrm{O}_{5}$ & 27,0 & & 27,0 & \\
\hline $\mathrm{ZrO}_{2}$ & 19,0 & & 19,0 & \\
\hline $\mathrm{Fe}$ & 30,0 & & 30,0 & \\
\hline \multicolumn{5}{|l|}{ содержание в концентрате, \% } \\
\hline $\mathrm{P}_{2} \mathrm{O}_{5}$ & 38,0 & & 38,0 & \\
\hline $\mathrm{ZrO}_{2}$ & 98,0 & & 98,0 & \\
\hline $\mathrm{Fe}$ & 58,0 & & 58,0 & \\
\hline \multicolumn{5}{|l|}{$\begin{array}{l}\text { 19. Выпуск конечной товарной } \\
\text { продукции, тыс. т }\end{array}$} \\
\hline $\begin{array}{l}\text { апатитовый конщентрат (38 \% } \\
\left.\mathrm{P}_{2} \mathrm{O}_{5}\right)\end{array}$ & 163,4 & & 163,4 & \\
\hline $\begin{array}{l}\text { бадделеитовый концентрат (98 \% } \\
\left.\mathrm{ZrO}_{2}\right)\end{array}$ & 1,939 & & 1,939 & \\
\hline $\begin{array}{l}\text { железорудный концентрат (58 \% } \\
\text { Fe) }\end{array}$ & 110,17 & & 110,17 & \\
\hline \multicolumn{5}{|l|}{$\begin{array}{l}\text { 20. Цена реализации единицы (т) } \\
\text { продукции, руб. }\end{array}$} \\
\hline $\begin{array}{l}\text { апатитовый концентрат (38 \% } \\
\left.\mathrm{P}_{2} \mathrm{O}_{5}\right)\end{array}$ & 6336,9 & & 10584 & \\
\hline бадделеитовый концентрат & 66040,5 & & 71703 & \\
\hline железорудный концентрат & 1182,0 & & 3263 & \\
\hline $\begin{array}{l}\text { 21. Стоимость продукции, общая и } \\
\text { каждого компонента, млн руб. }\end{array}$ & 1293,72 & & 2228,5 & \\
\hline апатитовый концентрат & 1035,45 & & 1730,5 & \\
\hline бадделеитовый концентрат & 128,05 & & 139,0 & \\
\hline железорудный концентрат & 130,22 & & 359,0 & \\
\hline
\end{tabular}


Окончание таблицы 5.14

\begin{tabular}{|c|c|c|c|c|}
\hline 1 & 2 & 3 & 4 & 5 \\
\hline 22. Капитальные затраты, млн руб. & 635,019 & & 635,020 & \\
\hline карьер & 77,129 & & 77,129 & \\
\hline $\begin{array}{l}\text { участок прикарьерной базы } \\
\text { подготовки ТМ }\end{array}$ & 334,101 & & 334,101 & \\
\hline $\begin{array}{l}\text { участок подготовки } \\
\text { флотации }\end{array}$ & 187,334 & & 187,334 & \\
\hline участок флотации & 36,455 & & 36,455 & \\
\hline 23. Оборотный капитал, млн руб. & 120,0 & & 120,0 & \\
\hline $\begin{array}{l}\text { 24. Удельные капитальные затраты } \\
\text { на одну тонну добычи, руб/т }\end{array}$ & 151,0 & & 151,0 & \\
\hline $\begin{array}{l}\text { 25. Эксплуатационные затраты, } \\
\text { млн руб. }\end{array}$ & 1197,7 & & 1197,7 & \\
\hline \multicolumn{5}{|l|}{ В том числе } \\
\hline амортизация & 11,76 & & 11,76 & \\
\hline НДПИ & - & & - & \\
\hline $\begin{array}{l}\text { 26. Затраты на одну тонну } \\
\text { полезного ископаемого, руб. }\end{array}$ & 239,54 & & 239,54 & \\
\hline добыча & 43,34 & & 43,34 & \\
\hline передел & 93,46 & & 93,46 & \\
\hline прочие & 102,74 & & 102,74 & \\
\hline 27. Валовая прибыль, млн руб. & 96,02 & & 1030,8 & \\
\hline $\begin{array}{l}\text { 28. Налог на имущество и } \\
\text { прочие платежи, млн руб. }\end{array}$ & 13,97 & & 13,97 & \\
\hline $\begin{array}{l}\text { 29. Налогооблагаемая прибыль, } \\
\text { млн руб. }\end{array}$ & 82,05 & & 1016,8 & \\
\hline 30. Налог на прибыль, млн руб. & 16,41 & & 203,4 & \\
\hline 31. Чистая прибыль, млн руб. & 65,64 & & 813,4 & \\
\hline 32. Ставка дисконтирования, \% & 10,0 & & 10,0 & \\
\hline $\begin{array}{l}\text { 33. Чистый дисконтированный } \\
\text { доход, млн руб. }\end{array}$ & 21,4 & & 4539,1 & \\
\hline 34. Индекс доходности, доли ед. & 1,04 & & 6,0 & \\
\hline $\begin{array}{l}\text { 36. Срок окупаемости } \\
\text { капиталовложений, лет }\end{array}$ & 11,5 & & 0,93 & \\
\hline То же с дисконтированием, лет & 18 & & 4,4 & \\
\hline $\begin{array}{l}\text { 37. Внутренняя норма доходности, } \\
\%\end{array}$ & 11,0 & & 48,0 & \\
\hline
\end{tabular}

В таблице 5.14 представлены основной вариант расчета с использованием фактических средневзвешенных цен реализации вырабатываемых ОАО «Ковдорский ГОК» концентратов и перспективный, но менее реалистичный вариант, предполагающий реализацию всего объема концентратов по максимально высоким ценам, зафиксированным в период выполнения работы по некоторым контрактам с отдельными потребителями. Основное значение второго - перспективного варианта состоит в том, чтобы показать, что при благоприятной рыночной 
конъюнктуре, касающейся, прежде всего, положительной тенденции в долгосрочной перспективе прироста спроса на фосфатные удобрения и сырьё для их производства для решения продовольственной проблемы увеличивающегося населения планеты, эффективность повторной переработки отходов второго поля резко повышается.

Вариант оценки с использованием цен на концентраты самого низкого уровня, зафиксированного по отдельным сделкам, применительно к такому бедному сырью, каким являются отходы (хвосты) второго поля, не может быть рекомендован к реализации из-за больших убытков. Результаты расчетов по этому варианту в работе не приводятся. Отрицательным оказался ЧДД и в варианте отработки запасов отходов только первого сорта при использовании средневзвешенного уровня цен (результаты не приводятся), поэтому более перспективной является валовая отработка отходов первого и второго сортов.

Основной из рассмотренных в работе вариант 1, предусматривающий отработку запасов отходов второго поля (сорт $1+$ сорт 2) при реализации готовых концентратов по средневзвешенным ценам, хотя и имеет положительный ЧДД, индекс доходности больше единицы, характеризуется длительным сроком окупаемости капиталовложений и небольшим запасом прочности (ВНД чуть больше принятой минимальной нормы ставки дисконтирования).

В этих условиях представляется необходимым дополнительно изучить и оценить эффективность следующих вариантов возможного повышения эффективности повторной отработки отходов (хвостов) второго поля хвостохранилища: 1) выделить из запасов отходов, подсчитанных в геологических границах залежи, более богатую часть на основе обоснованных в настоящей работе параметров кондиций (бортовых браковочных содержаний полезных компонентов и минимального промышленного содержания основного ценного компонента пентоксида фосфора); 2) изучить вопрос целесообразности и эффективности использования для отработки рыхлых отходов второго поля современных земснарядов, учитывая сложности гидрогеологических условий отработки отходов первого и особенно второго полей хвостохранилища, сложности и большие затраты на осушение действующего карьера на первом поле. При работе земснаряда не потребуется работ по осушению залежи, значительную часть шламов можно будет сбрасывать на месте и не транспортировать на обогатительную установку. Для выполнения подобной работы целесообразно привлечь компетентных специалистов, в частности, из Института Иргиредмет (г. Иркутск), имеющих большой положительный опыт по отработке рыхлых россыпных месторождений, включая отходы хвостохранилищ.

Таким образом, в результате выполненных исследований в качестве основного обеспечивающего рентабельность производства варианта повторной отработки предварительно оцененных и подсчитанных запасов отходов (хвостов) второго поля хвостохранилища рекомендуется совместная отработка первого и второго сортов. Имеются перспективы увеличения рентабельных к отработке запасов отходов за счет более богатых по апатиту прогнозных ресурсов, а также принципиальные направления поиска возможности повышения эффективности производства за счет выделения относительно более богатой части предварительно оцененных и подсчитанных запасов или перехода на другой способ отработки рыхлых отложений. В целом техногенные отходы второго поля являются подготовленной дополнительной резервной сырьевой базой ОАО «Ковдорский ГОК», которая учитывается в стратегии долгосрочного развития предприятия $[35,83]$. 


\section{Выводы по главе 5}

По мере освоения и совершенствования технологии использования ГПО, получаемая на их основе продукция может проходить разные стадии, от суррогатного неполноценного, но дешевого заменителя продукции, получаемой из другого сырья или по другой технологии, до высококачественной высококонкурентной продукции, соответственно, первоначально бросовые (не имеющие стоимости) отходы становятся высокоценным, возможно, стратегическим сырьем и должны получать адекватную стоимостную оценку.

Предложенная в дополнение к минимально-промышленному содержанию условного (основного целевого) компонента методика аналитического определения предельного (браковочного, бортового) содержания каждого ценного составляющего многокомпонентного техногенного горнопромышленного сырья позволяет повысить качество геолого-экономической оценки промышленных запасов техногенного сырья и определить варианты его дальнейшего использования.

Альтернативное использование ГПО (в качестве сырья для производства строительных материалов или при приготовлении закладочных смесей) возможно без ограничений только в случае, если фактические содержания в них всех ценных компонентов ниже соответствующих им предельных (браковочных); иначе они должны быть отнесены к потенциальным минеральным ресурсам. Предельные (браковочные, бортовые) содержания каждого из ценных компонентов определяются из условия окупаемости только прямых дополнительных затрат, возникающих при организации его производства, а при определении минимально-промышленного содержания условного компонента необходимо включать в расчет только те ценные составляющие, содержания которых выше соответствующего предельного (браковочного, бортового).

Накопленный ОАО «Ковдорский ГОК» положительный опыт, выявленные при этом особенности, проблемы, закономерности высокорентабельной промышленной эксплуатации ТМ первого поля хвостохранилища являются необходимой, надежной предпосылкой объективной оценки возможности и эффективности повторной переработки более бедных отходов (хвостов) обогащения, накопленных на предприятии в более поздние годы, в частности заскладированных во втором поле хвостохранилища.

Выполненная оценка экономической эффективности комплексной утилизации разведанных и предварительно оцененных запасов техногенного сырья в рамках второго поля хвостохранилища ОАО «Ковдорский ГОК» показала, что техногенные отходы второго поля являются подготовленной дополнительной резервной сырьевой базой ОАО «Ковдорский ГОК», которая учитывается в стратегии долгосрочного развитии предприятия. 


\section{ЗАКЛЮЧЕНИЕ}

Выполнено исследование, системно раскрывающее с позиций горноэкологической концепции рационального использования недр проблему накопления и использования ГПО как вторичных минеральных ресурсов в условиях перехода на НДТ. Требование рациональности в равной степени относится как к природным (первичным), так и к техногенным (вторичным) минеральным ресурсам. Ресурсный потенциал накопленных на территории России отходов горнодобывающих и связанных с ними производств сравним с ресурсным потенциалом крупных месторождений ТПИ. В то же время деятельность по добыче и переработке минерального сырья, рост накопления сопровождающих эту деятельность отходов оказывает серьезное негативное воздействие на экосистемы горнопромышленных регионов страны.

Изучение данных официальной статистики показало, что с 2005 по 2018 гг. среднегодовой темп накопления отходов добычи полезных ископаемых составил около $6 \%$ при среднегодовом темпе роста образования отходов 7,5\% и темпе их использования 9,1\%. Прирост объемов добычи полезных ископаемых за этот же период составил 18,8\%. Наблюдается значительное превышение темпа накопления отходов добычи над темпом роста объемов добычи полезных ископаемых, даже с учетом активизации в последние годы процесса использования (утилизации) отходов добычи и обогащения. Расчеты показали, что к началу 2019 г. на территории Российской Федерации накоплено отходов добычи и переработки полезных ископаемых не менее 113 млрд т.

Масштаб и характер проблем, связанных с отходами горнодобывающих производств, требует их рассмотрения в институциональном аспекте, когда они выступают объектом управления в существующей институциональной среде. Полученные в ходе исследования результаты позволили выделить четыре области институциональной среды, в которых необходимо совершенствовать отношения недропользования с целью активного вовлечения в хозяйственный оборот образуемых и накопленных ГПО, а также с целью снижения экологического ущерба, наносимого отходами природным экосистемам.

Первая область касается развития нормативной правовой базы и связана с преодолением неопределенностей терминологического характера, а также противоречий, вытекающих из двойного правового регулирования отношений пользования и владения ТМР, обращения с ними. В монографии рассмотрены пересекающиеся аспекты экологического законодательства и законодательства о недрах (горного) в отношении отходов добычи и обогащения минерального сырья. Сформулированы предложения по формированию непротиворечивого терминологического аппарата и нормативного закрепления понятий «вторичные минеральные ресурсы» и «техногенные минеральные ресурсы».

Уточнена и дополнена классификация ГПО путем введения двух дополнительных классификационных признаков: степень вовлеченности в хозяйственный оборот и имущественно-правовой статус. Рассмотрено содержание понятий «техногенное месторождение» и «потенциальное техногенное месторождение» как минеральных объектов. Показано, что использование категории «техногенный минеральный объект» позволяет рассматривать отходы добычи и переработки одновременно как минеральный ресурс техногенного генезиса и как 
объект управления этим ресурсом, что, со своей стороны, дает возможность рационально подойти $к$ решению проблемы комплексного использования добываемого минерального сырья, включая техногенное сырье. Разработана типология ТМО и сформулированы принципы типологии.

Вторая выделенная область институциональной среды касается совершенствования налогового законодательства в сфере обращения с отходами добычи и комплексной переработки многокомпонентного природного и техногенного рудного сырья. Существующая система налогообложения, по сути, дестимулирует комплексное использование сырья и переработку многокомпонентных техногенных отходов. Для стимулирующего льготного налогообложения рекомендуется разделить ГПО на ТМР и безвозвратные отходы, не имеющие потребительной ценности. С учетом многокомпонентного состава большинства добываемых рудных полезных ископаемых потери попутных полезных ископаемых и ценных компонентов, сопровождающие добычу основного полезного ископаемого, приводят к уменьшению налоговой базы по НДПИ и недополучению доходов недропользователями. В связи с этим возникает необходимость разработки новых подходов к дифференцированному налогообложению добычи. В работе предложена модель расчета дифференцированных налоговых ставок по НДПИ для многокомпонентного природного и техногенного минерального сырья.

Третья область институциональной среды связана с формированием единой системы управления ТМР на федеральном и региональном уровнях. Несмотря на огромное количество накопленных и ежегодно образующихся отходов горного производства в Российской Федерации отсутствует единая база данных о ТMO, а работа над созданием региональных кадастров ведется разобщенно. Предложен методический подход к созданию типового регионального кадастра техногенных месторождений и вариант формирования автоматизированной базы данных по ТМС, разработанный специалистами Горного института КНЦ РАН по материалам многолетних оценок техногенных объектов горнопромышленных производств Мурманской области.

Целесообразно сформировать на общих методологических основаниях единую систему региональных кадастров техногенных месторождений и баз данных по ТМО с замыканием этой системы на соответствующий раздел Государственного кадастра месторождений. Систематизация учета ТМО и обеспечение доступа к информационным ресурсам лиц, заинтересованных в использовании (утилизации) TMC, прежде всего малого и среднего бизнеса, расширит возможности для вовлечения ТМР в хозяйственный оборот. Предлагаемая схема предполагает выделение в системе управления недропользованием подсистемы управления ВМР с функцией координации ведения системы кадастров ТМО.

Четвертая область институциональной среды, выделенная нами, связана с расширением научных исследований и разработок по созданию инновационных технологий комплексного использования природного и техногенного минерального сырья. Анализ показывает, что вводимые в рамках нового регулирования экологические стимулы, такие как плата за НBOC, сами по себе не могут решить проблему создания и совершенствования НДТ, переход на которые, как ожидается, позволит улучшить экологическую ситуацию и придаст импульс технологической модернизации в сфере добычи ТПИ. Это отдельная масштабная и наиболее сложная задача, без последовательного решения которой новое экологическое регулирование превратится в привлекательную «обертку» к старой «конфете». 
Применительно к ВМР можно выделить два перспективных, на наш взгляд, дальнейших научных направления: 1) исследования в области разработки новых и оценки уже разработанных технологий, которые могут стать наилучшими доступными при использовании ТМР в качестве исходного сырья, включая изучение возможностей создания полигонов для разработки, модернизации и опытнопромышленных испытаний обновляемых технологических схем в рамках проектной кооперации заинтересованных горнодобывающих компаний, отраслевых исследовательских центров и государства; 2) исследование вопросов выработки критериев экономической эффективности переработки многокомпонентного природного и техногенного минерального сырья, других аспектов комплексного освоения минеральных ресурсов и реализации отходов добычи как товарного продукта, а также экономического обоснования целесообразности внедрения НДТ в тех или иных случаях.

Внедряемый в рамках нового экологического регулирования механизм НДТ может служить перспективной основой для перевода горнодобывающего сектора промышленности на новый технологический уровень. Он открывает новые возможности для повышения конкурентоспособности горнодобывающих производств, снижения уровня образуемых ими отходов и повышения инвестиционной привлекательности ВМР. 


\section{ЛИТЕРАТУРА}

1. Агошков М. И. Развитие идей и практики комплексного освоения недр. М.: Изд-во ИПКОН АН СССР, 1982. 25 с.

2. Алексеев В. С. Оценка обогатимости «хвостов» хвостохранилища Ковдорской обогатительной фабрики: информационный отчет // Фонды КНЦ АН СССР. Апатиты, 1976.

3. Анализ производства и потребления редкоземельных элементов в странах ЕС и БРИКС / А. Е. Череповицын и др. // Цветные металлы. 2015. № 5. С. 5-9.

4. Архипов А. В., Решетняк С. П. Техногенные месторождения. Разработка и формирование. Апатиты: КНЦ РАН, 2017. 175 с.

5. Астахов А. С. Экономика разведки, добычи и переработки полезных ископаемых (геоэкономика). М.: Недра, 1991. 315 с.

6. Балацкий О. Ф. Экология и экономика: справочник. Киев, 1986. С. 11-23.

7. Басовский Л. Е. Прогнозирование и планирование в условиях рынка. М.: ИНФРА-М, 2003. 260 с.

8. Бенуни А. Х. Развитие цветной металлургии и мобилизация резервов: доклад по выполненным и опубликованным работам на соискание ученой степени д-ра экон. наук. Свердловск, 1964. 65 с.

9. Березина Е. Чистая работа // Российская газета. 2018. 25 сент.

10. Березовский П. В. Экономическая оценка вторичных минеральных ресурсов: монография. СПб.: СПГГИ (ТУ), 2006. 163 с.

11. Блошенко Т. А. Методики определения дифференцированных ставок по налогу на добычу полезных ископаемых при добыче твердых полезных ископаемых // Экономика и предпринимательство. 2016. № 12-1. С. 120-127.

12. Блошенко Т. И. Методология налогообложения организаций при добыче и комплексной переработке минерального сырья: дис. ... д-ра экон. наук. M., 2019. 317 c.

13. Боголюбов С. А. Экологическое (природоресурсное) право. М., 2010. 528 с.

14. Боков В. Г., Заверткин В. Л., Лазарев В. Н. Богатство в отвалах (проблемы утилизации горнопромышленных отходов России) // Центр. 1994. № 8. С. 12 14.

15. Боярко Г. Ю. Налогообложение горного имущества // Разведка и охрана недр. 2004. № 2. С. 62-64.

16. Бусырев В. М., Чуркин О. Е. Оценка стоимости запасов и эффективности освоения техногенных месторождений // Горный информационноаналитический бюллетень. 2016. № 6. С. 106-114.

17. Быбочкин А. М., Сечевица А. М., Буриков Е. В. Принципы определения предельных содержаний рассеянных элементов для подсчета их запасов в комплексных рудах // Разведка и охрана недр. 1975. № 11. С. 16-22.

18. Быховский Л. 3., Спорыхина Л. В. Техногенные отходы как резерв пополнения минерально-сырьевой базы: состояние и проблемы освоения // Минеральные ресурсы России. Экономика и управление. 2011. № 4. С. 9-15.

19. Вернадский В. И. Биосфера и ноосфера. М.: Наука, 1969. 262 с.

20. Виноградов В. Н. Экономическая оценка комплексного минерального сырья. М.: Недра, 1978. 223 с. 
21. Волков В. Н., Макеев В. И. История и перспективы развития минеральносырьевого комплекса ОАО «Кольская ГМК» // Цветные металлы. 2013. № 10. C. 27-32.

22. Волынкина Е. П. Анализ состояния и проблем переработки техногенных отходов в России // Вестник Сибирского государственного индустриального университета. 2017. № 2 (20). С. 43-49.

23. Временное руководство по содержанию, оформлению и порядку представления на государственную экспертизу технико-экономических обоснований (ТЭО) кондиций на минеральное сырье. М.: ГКЗ Минприроды РФ, 1997. 38 с.

24. Временные требования к подсчету запасов попутных полезных ископаемых и компонентов в рудах и других видах минерального сырья. М.: ГКЗ СССР, 1973. $18 \mathrm{c.}$

25. Гальперин А. М., Кутепов Ю. И., Кириченко Ю. В. Освоение техногенных массивов на горных предприятиях: монография. М.: Горная книга, 2012. 336 с.

26. Гатов Т. А. Экономическая оценка месторождений цветных металлов. М.: Недра, 1975. 262 с.

27. Геологическая записка к ТЭО эффективности промышленного освоения отходов обогащения магнетитовых и апатитовых руд Ковдорского месторождения, заскладированных во 2 поле хвостохранилища ОАО «Ковдорский ГОК». Апатиты: ОАО «Мурманская ГРЭ», 2009. 792 с.

28. Гершенкоп А. Ш., Хохуля М. С., Мухина Т. Н. Переработка техногенного сырья Кольского полуострова // Вестник Кольского научного центра РАН. 2010. № 1. C. 4-8.

29. Гилярова А. А. О кадастре техногенных образований Кольского горнопромышленного региона // Тенденции развития науки и образования. 2018. № 5 (42). C. 32-35.

30. Гилярова А. А. О подходах к технико-экономической оценке перспективности освоения месторождений полезных ископаемых // Горный информационноаналитический бюллетень (научно-технический журнал). 2017. № 7. С. 211215.

31. Гончарова Л. И., Ларичкин Ф. Д., Переин В. Н. Потенциал техногенного минерального сырья в России и проблемы его рационального использования // Экономические и социальные перемены: факты, тенденции, прогноз. 2015. № 5 (41). С. 104-117.

32. Горлова О. С. Техногенные месторождения полезных ископаемых. Магнитогорск: МГТУ им. Н. Носова, 2001. 77 с.

33. Горно-промышленные отходы - дополнительный источник минерального сырья / М. А. Комаров и др. // Минеральные ресурсы России. Экономика и управление. 2007. № 4. С. 3-9.

34. Горный журнал. Специальный выпуск: «Ковдорский ГОК». 2002.

35. Горный журнал. №10. Специальный выпуск: Еврохим. Ковдорский горнообогатительный комбинат. 2012.

36. Грацерштейн И. М., Нежинская Л. А. Комплексное использование полиметаллического сырья. М.: Металлургиздат, 1961. 124 с.

37. Два аспекта проблемы утилизации горно-промышленных отходов / Б. И. Беневольский и др. // Минеральные ресурсы России: экономика и управление. 2011. № 1. С. 37-42. 
38. Добыча и обогащение лежалых «хвостов» техногенного месторождения с целью поддержания мощности Ковдорского ГОКа». Проект ОАО «Гипроруда и НИПЭЦ «Промгидротехника». СПб., 1997.

39. Друри К. Введение в управленческий и производственный учет: учеб. пособие для вузов / пер. с англ.; под ред. Н. Д. Эриашвили. 3-е изд., перераб. и доп. М.: Аудит, ЮНИТИ, 1998. 783 с.

40. Дудиков М. В., Мелехин Е. С. Государственное регулирование рационального недропользования // Маркшейдерия и недропользование. 2011. № 1 (51). С. 19-23.

41. Дулин А. Н., Куликов М. М., Дулин Р. А. Рациональное использование природно-ресурсной базы техногенных месторождений на региональном уровне (на примере Восточного Донбасса): монография. Новочеркасск: ЮРГТУ (НПИ), 2009. 110 с.

42. Жаворонкова И. П. Экономические вопросы улучшения испльзования сырьевых ресурсов СССР. М.: Наука, 1973. 198 с.

43. Зотов В. В., Пресняков В. Ф., Розенталь В. О. Институциональные проблемы реализации системных функций экономики // Экономическая наука современной России. 2001. № 3. С. 51-59.

44. Иванов А. Что делается для реализации национального проекта «Экология» // Российская газета RG.RU. 2019. 13 марта.

45. Информационные технологии в горном деле / А. А. Козырев и др. Апатиты: КНЦ РАН, 1998. Ч. 1. 188 с.

46. Исследования хвостохранилищ горно-обогатительных предприятий Кольского региона: анализ структуры затрат / А. И. Калашник и др. // Север и рынок: формирование экономического порядка. 2015. № 2 (45). С. 31-39.

47. Кадастр отходов горно-металлургического производства Мурманской области (по состоянию на 01.01.2000г.) / Горный институт КНЦ РАН; Государственный комитет по охране окружающей среды Мурманской области. Апатиты; Мурманск, 2000.

48. Калашник А. И. Методология применения информационных технологий при освоении минерально-сырьевых ресурсов Кольского полуострова // Наука и образование. 10 лет вместе. Апатиты: КНЦ РАН, 2005. С. 132-139.

49. Калинин И. Б. Природоресурсное право. Томск: Томский университет, 2009. $350 \mathrm{c}$.

50. Калинников В. Т. Комплексное освоение месторождений Кольского полуострова // Журнал прикладной химии. 1997. Вып. 5. С. 705-711.

51. Каретников Е. В. Диагностика и регулирование издержек при комплексной переработке минерального сырья: автореф. дис. ... канд. экон. наук. Апатиты: ИЭП КНЦ РАН, 2002. 18 с.

52. Карпенко Н. Б. Правовые аспекты учета и переработки техногенных месторождений // Золотодобыча. 2010. № 140. С. 12-18.

53. Касиков А. Г Проблемы и перспективы вовлечения в хозяйственный оборот отвальных продуктов медно-никелевого производства // Север и рынок: формирование экономического порядка. 2013. № 1 (32). С. 48-52.

54. Кныш В. А., Невская М. А. Эффективное управление горнопромышленными отходами как условие рационального недропользования // Теория и практика сервиса. Экономика, социальная сфера, технологии. 2015. № 4 (26). С. 39-43. 
55. Кныш В. А., Невская М. А., Череповицын А. Е. Проблемные аспекты внедрения механизма НДТ в горнодобывающей промышленности // Рациональное освоение недр. 2019. № 2-3. С. 38-47.

56. Комплекс по обогащению бадделеит-апатитовых песков техногенного месторождения первого поля хвостохранилища. Рабочий проект. СПб.: ЗАО «Механобр Инжиниринг», 2005.

57. Комплексное использование руд и концентратов / В. А. Резниченко и др. М.: Наука, 1989. 171 с.

58. Комплексное обогащение нефелинового сырья Хибин / Л. Д. Ратобыльская и др. // Комплексное обогащение фосфорсодержащего сырья. Апатиты: КФ АН CССР, 1977. С. $77-86$.

59. Комплексное устойчивое управление отходами. Горнодобывающая промышленность / Е. Гидаракос и др. М.: Издательский дом Академии естествознания, 2016. С. 538-540.

60. Кривая бескупонной доходности на рынке ГКО - ОФЗ / Г. Гамбаров и др. // Рынок ценных бумаг. 2006. № 3. С. 68-77.

61. Крюков В. А. Институциональные условия недропользования в России: результаты и следствия // Регион: экономика и социология. 2006. № 1. С. 72-93.

62. Кузнецов Г. Д. Калькулирование себестоимости продуктов переработки комплексного сырья. М.: Экономика, 1964. 136 с.

63. Курошев И. С., Макеенко П. А., Доброхотова М. В. Горнодобывающая промышленность. Отраслевой обзор и концепция системы справочников НДТ // Наилучшие доступные технологии. Применение в различных отраслях промышленности: сб. ст. М.: Перо, 2016. № 4. С. 78-98.

64. Кябби М. Э. Экономический механизм комплексного освоения недр. М.: Недра, 1984. 200 с.

65. Ларичкин Ф. Д. Исследование эффективности комплексного использования сырья (на примере обогатительных фабрик свинцово-цинковой промышленности): автореф. дис. ... канд. экон. наук. Свердловск, 1974. 31 с.

66. Ларичкин Ф. Д. Научные основы оценки экономической эффективности комплексного использования минерального сырья. Апатиты: КНЦ РАН, 2004. $252 \mathrm{c}$.

67. Ларичкин Ф. Д. Оценка экономической эффективности комплексного использования минерального сырья: учеб. пособие для вузов. Апатиты: КНЦ РАН, 2005. $143 \mathrm{c.}$

68. Ларичкин Ф. Д. Теория и практика стоимостной оценки полезных компонентов в минеральном сырье и продуктах его комплексной переработки. М.: НП НАЭН, 2008. 88 с.

69. Ларичкин Ф. Д., Пономаренко Т. В. Затраты в комбинированных горнопромышленных производствах: формирование и управление. Апатиты: КНЦ РАН, 2012. 154 с.

70. Лексин В. Н., Токарева А. Г. Экономика комплексного использования полиметаллического сырья. М.: Металлургия, 1968. 252 с.

71. Лемешев М. Я., Чепурных Н. В., Юрина Н. П. Рациональное природопользование: на пути к гармонии. М., 1986. 259 с.

72. Малышев Ю. Н. Развитие горнопромышленного комплекса в условиях обострения конкуренции на мировых рынках минеральных ресурсов // Минеральные ресурсы России. Экономика и управление. 2013. № 1. С. 17-19. 
73. Мельников Н. В. Минерально-сырьевые ресурсы и комплексное их освоение. Избранные труды. М.: Наука, 1987. 300 с.

74. Мельников Н. В., Агошков М. И. Задачи научных исследований в области комплексного освоения месторождений, использования минерального сырья и охраны недр // Комплексное использование минерального сырья, 1979. № 7. С. 3-11.

75. Мельников Н. Н. Информационные технологии в реализации экологической стратегии развития горнодобывающей отрасли // Горный информационно-аналитический бюллетень (научно-технический журнал). 2017. № S 23. C. 7-18.

76. Мельников Н. Н., Бусырев В. М., Чуркин О. Е. Оценка стоимости запасов и эффективности использования техногенных месторождений // Горный информационно-аналитический бюллетень. 2018. № 8. С. 200-207.

77. Металлургические технологии переработки техногенных месторождений, промышленных и бытовых отходов / С. Н. Кузнецов и др. Новосибирск: CO PAH, 2014. 294 c.

78. Методические рекомендации по геолого-экономическому обоснованию кондиций для подсчета запасов месторождений твердых полезных ископаемых (кроме углей и горючих сланцев). М.: ГКЗ Минприроды РФ, 1999. 35 с.

79. Методические рекомендации по комплексному изучению месторождений и подсчету запасов попутных полезных ископаемых и компонентов. М.: ФГУ «ГКЗ», 2007. 15 c.

80. Методические рекомендации по оценке эффективности инвестиционных проектов и их отбору для финансирования. М.: НПКВЦ «Теринвест», 1994. $80 \mathrm{c}$.

81. Методические рекомендации по оценке эффективности инвестиционных проектов (вторая редакция). Официальное издание. М.: Экономика, 2000. 421 с.

82. Методические рекомендации по технико-экономическому обоснованию кондиций для подсчета запасов месторождений твердых полезных ископаемых (кроме углей и горючих сланцев): утв. распоряжением МПР России от 05.06.2007 г. № 37-р. М.: НП НАЭН, 2007. 60 с.

83. Модернизация минерально-сырьевой базы в стратегии долгосрочного развития Ковдорского ГОКа / А. И. Петрик и др. // Горный журнал. 2012. № 10. C. 12-17.

84. Наилучшие доступные технологии и комплексные экологические разрешения: перспективы применения в России / М. В. Бегак и др.; под ред. М. В. Бегака. М.: ООО «ЮрИнфоР-Пресс», 2010. 218 с.

85. Наилучшие доступные технологии: опыт и перспективы / Е. Б. Королева и др. СПб., 2011. 123 с.

86. Наилучшие доступные технологии. Применение в различных отраслях промышленности: сб. ст. М.: Перо, 2014. 124 с.

87. Невская М. А. Определение природных ресурсов как объекта экономических отношений: экономико-правовой аспект // Проблемы геологии, планетологии, геоэкологии и рационального природопользования. Новочеркасск: ЮРГТУ (НПИ), 2010. С. 144-149.

88. Невская М. А. Согласование систем учета отходов горнодобывающих производств в недропользовании // Горнодобывающая промышленность 
Баренцева Евро-Арктического региона: взгляд в будущее: тез. докл. IV междунар. конф. (Кировск, 20-21 ноября 2014 г.). Мурманск, 2015. С. 50-56.

89. Невская М. А., Кныш В. А. Институциональные аспекты развития системы управления отходами горного производства // Экономические проблемы и механизмы развития минерально-сырьевого комплекса (российский и мировой опыт): сб. науч. тр. СПб.: Национальный минерально-сырьевой университет «Горный», 2016. С. 88-92.

90. Новоселов А. Л., Петров И. В. Моделирование использования вторичных минеральных ресурсов // Горный журнал. 2019. № 7. С. 80-84.

91. О методологии обоснования параметров кондиций на месторождениях многокомпонентных руд: анализ нормативно-методической документации / Ф. Д. Ларичкин и др. // Горный журнал. 2011. № 7. С. 36-39.

92. О методологии обоснования параметров кондиций на месторождениях многокомпонентных руд: учет специфики комплексного использования сырья при обосновании параметров кондиций / Ф. Д. Ларичкин и др. // Горный журнал. 2011. № 8. С. 69-72.

93. Отработка техногенного месторождения первого поля хвостохранилища ОАО «Ковдорский ГОК» (Вторая очередь). СПб.: Гипроруда, 2007.

94. Отраслевая методика кадастрового учета отходов горно-обогатительного и металлургического производства предприятий цветной металлургии / В. И. Чалов и др. М.: ЦНИИцветмет экономики и информации, 1987. 99 с.

95. Оценка эффективности переработки техногенного сырья рудных месторождений Кольского горнопромышленного комплекса / Е. В. Громов и др. // Север и рынок: формирование экономического порядка. 2018. № 3 (59). C. 77-78.

96. Ощепкова А. З., Венчикова В. Р. Новая система регулирования негативного воздействия на окружающую среду // Экология производства. 2019, сентябрь. C. 8-19.

97. Пахальчик Г. Ю. Программы переработки техногенных образований Свердловской области // Известия вузов. Горный журнал. 1997. № 11-12. C. 12-20.

98. Певзнер М. Е. Право собственности в недропользовании // Государство и право. 2002. № 3. С. 27-32.

99. Педан М. П., Мищенко В. С. Комплексное использование минеральных ресурсов. Киев: Наукова думка, 1981. 272 с.

100. Первушин С. А. Основные резервы развития цветной металлургии. М.: Металлургиздат, 1963. $219 \mathrm{c.}$

101. Переход к новому государственному регулированию на основе НДТ / О. В. Гревцов и др. // Экология производства. 2019, апрель. С. 83-89.

102. Перспективы использования нефелина / С. Г. Федоров и др. // Цветные металлы. 2000. № 10. С. 26-30.

103. Перчик А. И. Горное право: учебник. 2-е изд. М., 2002. 525 с.

104. Пешкова Г. Ю. Отраслевые проблемы развития горнопромышленного комплекса Ленинградской области // Известия ТулГУ. Экономические и юридические науки. Тула: изд. ТулГУ, 2016. С. 281-286.

105. Пономарев М. В. Право собственности на отходы: правовые проблемы реализации и перехода // Журнал российского права. 2017. № 8. С. 53-64. 
106. Попов В. В. Минеральные ресурсы и экономические перспективы России // Горное производство и наука на рубеже веков. Вестник горнометаллургической секции (Отделение горных наук). М., 1996. С. 55-63.

107. Пучков Л. А. Устойчивое энергопотребление - основа устойчивого развития мира // Устойчивое развитие горных территорий. 2015. Т. 7, № 4. С. 9-16.

108. 50 лет по пути инновационного развития / Д. С. Стрежнев и др. // Горный журнал. 2012. № 10. С. 7-11.

109. Рациональное использование Прибалтийских фосфоритов / Ф. Д. Ларичкин и др. Таллинн: Валгус, 1986. 141 с.

110. Ребрик И. И., Кочешков А. Ю., Борисовская И. А. Наилучшие доступные технологии: планы и реальность. Объединенная компания «РУСАЛ» // Эко-бюллетень ИнЭкА. 2009. № 3 (134), май — июнь.

111. Рыльникова М. В., Радченко Д. Н., Экс В. В. Классификация техногенных георесурсов в свете перспектив комплексного освоения рудных месторождений // Горный информационно-аналитический бюллетень (научно-технический журнал). 2012. № 2. С. 318-324.

112. Секисов Г. В., Зыков Н. В. Освоение минеральных объектов и методология оценки. М.: Горная книга, 2012. 430 с.

113. Селезнев С. Г., Степанов Н. А. Минерально-сырьевое богатство на поверхности. Особенности техногенных объектов и проблемы их освоения // Рациональное освоение недр. 2012. № 6. С. 14-22.

114. Сечевица А. М. Геолого-промышленная оценка попутных полезных ископаемых в комплексных рудных месторождениях. М.: Недра,1987. 126 с.

115. Соколов Ю. И. Арктика: к проблеме накопленного экологического ущерба // Арктика: экология и экономика. 2013. № 2 (10). С. 18-27.

116. Сорокина Т. П., Бердичевский Р. И. Предварительная оценка целесообразности использования «хвостов» из хвостов железорудной фабрики Ковдорского ГОКа для получения кондиционного апатитового концентрата: отчет института «Механобр». Л., 1976.

117. Специфика учета и управления ресурсами и затратами в комбинированных горнопромышленных производствах: монография / Ф. Д. Ларичкин и др.; под ред. Ф. Д. Ларичкина, А. Г. Воробьева. Апатиты: КНЦ РАН; ИЭП, 2012. 285 с.

118. Сравнительный анализ процедур разработки, пересмотра и актуализации справочников по наилучшим доступным технологиям в Европейском союзе и Российской Федерации / Д. О. Скобелев и др.; под ред. Д. О. Скобелева (на русском и английском языках). М.: Перо, 2018. 114 с.

119. Стратегии сырьевого обеспечения в народнохозяйственном развитии / А. А. Арбатов и др. М.: Наука, 1989. 279 с.

120. Теоретические основы создания новых малоэнергоемких огнестойких строительных материалов из вторичных минеральных ресурсов с использованием механохимии: монография / М. В. Луханин и др. М.: изд. Ассоциации строительных вузов, 2008. 102 с.

121. Теория и практика ценообразования на продукцию комплексной переработки минерального сырья / Ф. Д. Ларичкин и др. // Национальные интересы: приоритеты и безопасность. 2010. № 32 (89). С. 24-30. 
122. Технико-экономическое обоснование эффективности освоения отходов (хвостов) обогащения 2-го поля хвостохранилища ОАО «Ковдорский ГОК»: отчет о НИР / Ларичкин Ф. Д. и др. Апатиты: ИЭП КНЦ РАН, 2009.

123. Техногенные месторождения Среднего Урала и оценка их воздействия на окружающую среду / С. И. Мормиль и др.; ред. Ю. А. Боровков. Екатеринбург: НИА - Природа, АООТ «ВНИИЗАРУБЕЖГЕОЛОГИЯ», 2002. 206 с.

124. Техногенные минерально-сырьевые ресурсы / Б. К. Михайлов и др.; под ред. Б. К. Михайлова. М.: Научный мир, 2012. 234 с.

125. Техногенные ресурсы России. Общие сведения: справочник / 3. М. Шуленина и др. М.: Геоинформмарк, 2001. 199 с.

126. Требования к комплексному изучению месторождений и подсчету запасов попутных полезных компонентов. М.: ГКЗ СССР, 1982. 20 с.

127. Трофимец С. С. Правовое регулирование обращения с отходами производства и потребления: дис. ... канд. юрид. наук. Уфа, 2006. 169 с.

128. Трубецкой К. Н., Уманец В. Н. Комплексное освоение техногенных месторождений // Горный журнал. 1992. № 1. С. 12-16.

129. Трубецкой К. Н., Галченко Ю. П., Бурцев Л. И. Экологические проблемы освоения недр при устойчивом развитии природы и общества. М.: Научтехлитиздат, 2003. 261 с.

130. Трубецкой К. Н., Рогов Е. И., Никитин М. Б. Обоснования оптимальных параметров создания и разработки техногенных месторождений // Комплексное использование минерального сырья. 1986. № 8. С. 7-11.

131. Трубецкой К. Н., Уманец В. Н., Никитин М. Б. Классификация техногенных месторождений, основные категории и понятия // Горный журнал. 1989. № 12. С. 6-9.

132. Федосеев В. А. Эффективность использования минерального сырья в условиях Крайнего Севера. Л.: Наука, 1979. 215 с.

133. Ферсман А. Е. Комплексное использование ископаемого сырья. Л.: АН СССР, 1932. $20 \mathrm{c}$.

134. Хайкин М. М., Невская М. А. Регулирование хозяйственных отношений в сфере горнопромышленных отходов // Проблемы современной экономики. 2016. № 4 (60). С. 64-71.

135. Хан Д. Планирование и контроль: концепция контроллинга. М.: Финансы и статистика, 1997. 765 с.

136. Харитонова Г. Н. Сценарии экологической модернизации горнодобывающих корпораций на инновационной основе // Экономические и социальные перемены: факты, тенденции, прогноз. 2011. № 3 (15). С. 123-130.

137. Харитонова Г. Н., Алиева Т. Е. Методологические и методические проблемы определения наилучших доступных технологий для предприятий зоны Арктики // Север и рынок: формирование экономического порядка. 2015. № 3 (46). C. 67-74.

138. Хасанова Г. Г. Методические принципы кадастровой оценки техногенноминеральных образований Среднего Урала: дис. ... канд. геол.-мин. наук. Екатеринбург, 2003. 222 с.

139. Холодняков Г. А., Лигоцкий Д. Н. Малоотходные технологии открытой разработки месторождений полезных ископаемых. СПб.: Изд. НМСУ «Горный», 2015. 277 с. 
140. Худякова Л. И., Войлошников О. В., Тимофеева С. С. Магнийсиликатные породы горнодобывающей промышленности и технологии их утилизации. Новосибирск: Академическое изд-во «Гео», 2014. 175 с.

141. Цены и ценообразование: учебник для вузов / под ред. В. Е. Есипова. 3-е изд. СПб.: Питер, 1999. 464 с.

142. Цуранова А. И. Правовой механизм обеспечения рационального использования недр при геологическом изучении, разведке и добыче полезных ископаемых: автореф. ... дис. канд. юрид. наук. М.: 2014. 183c.

143. Цуранова А. И. Рациональное использование недр: понятие и юридические критерии // Журнал российского права. 2013. № 9. С. 95-99.

144. Чайников В. В., Гольдман Е. Л. Оценка инвестиций в освоение техногенных месторождений. М.: ООО «Недра-Бизнесцентр», 2000. С. 49.

145. Чантурия В. А. Теоретические основы повышения контрастности свойств и эффективности разделения минеральных компонентов // Цветные металлы. 1998. № 9. С. 11-17.

146. Черноусов П. И. Рециклинг. Технологии переработки и утилизации техногенных образований и отходов в черной металлургии. М.: МИСиС, 2011. $427 \mathrm{c}$.

147. Чернявский А. Г. О геолого-экономической и стоимостной оценке объектов твердых полезных ископаемых // Минеральные ресурсы в России. Экономика и управление. 2013. № 2. С. 19-26.

148. Экономика, организация, управление природными и техногенными ресурсами: учеб. пособие / В. Г. Гридин и др.; под ред. проф. А. А. Кобякова и проф. В. А. Харченко. М.: Горная книга, 2012. 752 с.

149. Экономика предприятия: учебник для вузов / под ред. П. П. Табурчака и В. М. Тумина. СПб.: Химиздат, 2001. 302 с.

150. Юрченко Ю. В. Использование отходов производства: возможности и ограничения // Экологический вестник России. 2019. № 2. С. 32-36.

151. Яковец Ю. В. Методологические вопросы рационального использования природных ресурсов // Ценообразование и стимулирование рационального использования природных ресурсов. М., 1977. С. 3-9.

152. Court H., Leurion J. Comptabilite analytique et gestion. Vol. 2. Paris: Foucher, 1985.

153. Culmann H. La comptabilite de l'entreprise. Paris: PUF, 1974.

154. Davis L. and North D. Institutional Change and American Economic Growth, Cambridge, 1971. P. 6.

155. De Narbonn M. Prix de revient et comptabilite de gestion. Paris: Dunod, 1975.

156. Didenko N., Kunze K., Skripnuk D. Russian Export Strategy and Social Sector: Consequences of Resource-Oriented Exports on Population of Russia // Mediterranean Journal of Social Sciences. 2015. Vol. 6, No. 5. P. 473-481.

157. Fontain C. Le developpement des aktivite de service aux entreprise et dans les entreprises // Revue d'economie industrielle. Paris, 1988. No. 43. P. 6-19.

158. Integrated Pollution Prevention and Control: current practices and prospects for the development in Russia / T. Guseva et al. // Proceedings of the 14th International Multidisciplinary Scientific Geo-Conference SGEM-2014. Book 5, Vol. 2. P. 391-398.

159. Knysh V. A., Larichkin F. D. Governmental stimulation of the mining waste processing in the Arctic zone // IOP Conference Series: Earth and Environmental Science. 2019. Vol. 302. P. 012043. 
160. Lawrence L. Vance. Theory and Techniques of Cost Accounting. N. Y.: Henry and Co., 1958.

161. Nevskaya M. A., Marinina O. A. Institutional environment of the mining waste management of the EU countries and Russia // Research Journal of Pharmaceutical, Biological and Chemical Sciences. 2016. Vol. 7, No. 4. P. 2352-2359.

162. OECD Project on best available techniques for preventing and controlling industrial chemical pollution - Results of Activity 2. / ed. by Derden An \& Van den Abeele Liesbet. Vito, 2017.

163. Schlatter C. F., Schlatter W. J. Cost Accounting. 2d ed. N. Y.: John Wiley and Sons, 1957.

164. Slater K., Wootton C. Joint and By-product Costing in the UK. Institute of Cost and Management Accounting, 1984.

\section{Законодательные и нормативные правовые акты}

165. Базельская конвенция о контроле за трансграничной перевозкой опасных отходов и их удалением. Ратифицирована Федеральным законом РФ от 25.11.1994 № 49-Ф3) // Консорциум Кодекс: сайт. URL: http://docs.cntd.ru/document/1901208.

166. О внесении изменений в Федеральный закон «Об отходах производства и потребления», отдельные законодательные акты Российской Федерации и признании утратившими силу отдельных законодательных актов (положений законодательных актов) Российской Федерации (с изм. и доп., вступ. в силу с 01.01.2019): Федеральный закон от 29.12.2014 № 458-ФЗ: принят Гос. Думой 23.12.2014; одобрен Советом Федерации 25.12. 2014 (ред. от 03.04.2018) // КонсультантПлюс: интернет-портал правовой информации. URL: http://www.consultant.ru/document/cons_doc_LAW_172948/.

167. О внесении изменений в Федеральный закон «Об охране окружающей среды» и отдельные законодательные акты Российской Федерации: Федеральный закон от 21.07.2014 № 219-Ф3: принят Гос. Думой 02.07.2014; одобрен Советом Федерации 09.07.2014 (ред. от 26.07.2019) // КонсультантПлюс: интернет-портал правовой информации. URL: http://www.consultant.ru/document/cons_doc_LAW_165823/.

168. О недрах: Закон Российской Федерации от 21.02.1992 № 2395-1 (в ред. от 03.03.1995, с изм. на 02.08.2019) // КонсультантПлюс: интернет-портал правовой информации. URL: http://www.consultant.ru/document/ cons_doc_LAW_343/.

169. Об отходах производства и потребления: Федеральный закон от 24.06.1998 № 89-ФЗ: принят Гос. Думой 22.05.1998; одобрен Советом Федерации 10.06. 1998 (ред. от 30.12.2008, с изм. на 02.08.2019) // КонсультантПлюс: интернет-портал правовой информации. URL: http://www.consultant.ru/document/cons_doc LAW_19109/.

170. Об охране окружающей среды: Федеральный закон от 10.01.2002 № 7-Ф3: принят Гос. Думой 20.12.2001; одобрен Советом Федерации 26.12.2001 (ред. от 26.07.2019) // КонсультантПлюс: интернет-портал правовой информации. URL: http://www.consultant.ru/document/cons_doc_LAW_34823/. 
171. Основы государственной политики в области экологического развития в Российской Федерации на период до 2030 года: утв. Президентом РФ 30.04.2012 // КонсультантПлюс: офиц. интернет-портал. URL: http://www.consultant.ru/document/cons_doc_LAW_129117/.

172. Постановление Правительства РФ от 24.06 .1996 № 738 “О Федеральной целевой программе «Переработка техногенных образований в Свердловской области»" // Собрание законодательства РФ. 1996. № 27, ст. 3237. 1 июля.

173. Постановление Правительства РФ от 30.12.2013 № 1312 «Об утверждении правил предоставления субсидий из федерального бюджета российским организациям на компенсацию части затрат на проведение НИОКР по приоритетным направлениям гражданской промышленности в рамках реализации такими организациями комплексных инвестиционных проектов» (в редакции Постановления от 26.05.2018 № 599) // Официальный интернетпортал правовой информации. URL: http://pravo.gov.ru/proxy/ips/?docbody= \&link_id $=0 \&$ nd $=102170701 \&$ intelsearch $=\&$ firstDoc $=1$.

174. Постановление Правительства РФ от 11.10.2014 № 1044 «Об утверждении Программы поддержки инвестиционных проектов, реализуемых на территории Российской Федерации на основе проектного финансирования (в редакции Постановления Правительства РФ от 30.12.2018 № 1758) // КонсультантПлюс: официал. интернет-портал. URL: http://www.consultant.ru/document/cons_doc_LAW_169755/.

175. Постановление Правительства РФ от 23.12.2014 № 1458 «О порядке определения технологии в качестве НДТ, а также разработки, актуализации и опубликования ИТС по НДТ (в ред. постановлений Правительства РФ от 09.09.2015 № 954, от 28.12.2016 № 1508, от 09.03.2019 № 250) // Официальный интернет-портал правовой информации. URL: http://pravo.gov.ru/proxy/ips/ ?docbody $=$ \&nd $=102364534$ \&intelsearch $=23.12 .2014+\mathrm{N}+1458$.

176. Постановление Правительства РФ от 28.08.2015 № 903 «Об утверждении критериев определения объектов, подлежащих федеральному государственному экологическому надзору» // КонсультантПлюс: официал. интернет-портал. URL: http://www.consultant.ru/document/ cons_doc_LAW_185330/.

177. Постановление Правительства РФ от 28.09.2015 № 1029 «Об утверждении критериев отнесения объектов, оказывающих негативное воздействие на окружающую среду, к объектам I, II, III и IV категорий» // КонсультантПлюс: официал. интернет-портал. URL: http://www.consultant.ru/document/ cons_doc_LAW_186693/.

178. Постановление Правительства РФ от 13.09.2016 № 913 (ред. от 29.06.2018) «О ставках платы за негативное воздействие на окружающую среду и дополнительных коэффициентах» // КонсультантПлюс: официал. интернет-портал. URL: http://www.consultant.ru/document/ cons_doc_LAW_204671/.

179. Постановление Правительства РФ от 13.02.2019 № 143 «О порядке выдачи комплексных экологических разрешений, их переоформления, пересмотра, внесения в них изменений, а также отзыва» // Правительство России: официал. сайт. URL: http://government.ru/docs/35760/.

180. Приказ Минприроды России от 14.02.2019 № 89 «Об утверждении Правил разработки технологических нормативов» // КонсультантПлюс: официал. 
интернет-портал. $\quad$ URL: http://www.consultant.ru/document/cons_doc_ LAW 321772/.

181. Приказ Минприроды России от 04.12.2014 № 536 «Об утверждении Критериев отнесения отходов к I-V классам опасности по степени негативного воздействия на окружающую среду»// КонсультантПлюс: официал. интернет-портал. URL: http://www.consultant.ru/document/ cons_doc_LAW_192145/.

182. Приказ Минприроды России от 18.04.2018 № 154 «Об утверждении перечня объектов, оказывающих негативное воздействие на окружающую среду, относящихся к I категории, вклад которых в суммарные выбросы, сбросы загрязняющих веществ в Российской Федерации составляет не менее чем 60 процентов» // КонсультантПлюс: официал. интернет-портал. URL: http://www.consultant.ru/document/cons_doc_LAW_301627/.

183. Приказ Минприроды РФ от 14.06.2018 № 261 «Об утверждении формы отчета об организации и о результатах осуществления производственного экологического контроля» // КонсультантПлюс: официал. интернетпортал. URL: http://www.consultant.ru/document/cons_doc_LAW_306002/.

184. Распоряжение Правительства РФ от 19.03.2014 № 398-р «О комплексе мер, направленных на отказ от использования устаревших и неэффективных технологий, переход на принципы наилучших доступных технологий и внедрение современных технологий» (с изм. № 1678-р от 29.08.2015) // Система ГАРАНT. URL: http://ivo.garant.ru/\#/document/ 70619522/paragraph/8:1.

185. Распоряжение Правительства Российской Федерации от 08.07.2015 № 1316-р (ред. от 10.05.2019) «Об утверждении перечня загрязняющих веществ, в отношении которых применяются меры государственного регулирования в области охраны окружающей среды» // КонсультантПлюс: официал. интернетпортал. URL: http://www.consultant.ru/ document/cons doc LAW 182546/.

186. Распоряжение Правительства РФ от 25.01.2018 № 84-р «Об утверждении Стратегии развития промышленности по обработке, утилизации и обезвреживанию отходов производства и потребления на период до 2030 года» // КонсультантПлюс: официал. интернет-портал. URL: http://www.consultant.ru/document/cons_doc_LAW_289114/.

187. Стратегия экологической безопасности Российской Федерации на период до 2025 года: утв. Указом Президента РФ от 19.04.2017 № 176. Ст. 26, 27 // ГАРАНТ: офиц. интернет-портал. URL: http://base.garant.ru/71659074/.

188. Commission Decision of 16 May 2011 establishing a forum for the exchange of information pursuant to Article 13 of the Directive 2010/75/EU on industrial emissions (2011/C 146/03). Official Journal of the European Union, C 146/3, 17.5.2011 // EUR-Lex. URL: https://eur-lex.europa.eu/LexUriServ/LexUriServ.do? uri=OJ:C:2011:146:0003:0004:EN:PDF.

189. Commission Implementing Decision of 10 February 2012 laying down rules concerning guidance on the collection of data and on the drawing up of BAT reference documents and on their quality assurance referred to in Directive 2010/75/EU of the European Parliament and of the Council on industrial emissions. Official Journal of the European Union, L 63/1, 2.3.2012 // EURLex. URL: https://eur-lex.europa.eu/legal-content/GA/TXT/?uri= CELEX:32012D0119. 
190. Council Directive of 28 June 1984 on the combating of air pollution from industrial plants (84/360/EEC). Official Journal of the European Union, L 188, 16.7.1984, p. 20-25 // EUR-Lex. URL: https://eur-lex.europa.eu/legalcontent/EN/TXT/?uri=CELEX\%3A31984L0360.

191. Council Directive 96/61/EC of 24 September 1996 concerning integrated pollution prevention and control. Official Journal of the European Union, L 257, 10/10/1996. P. 26-40 // EUR-Lex. URL: https://eur-lex.europa.eu/legalcontent/EN/TXT/?uri=CELEX\%3A31996L0061.

192. Directive 2006/21/EC of the European Parliament and of the Council of 15 March 2006 on the management of waste from extractive industries and amending Directive 2004/35/EC - Statement by the European Parliament, the Council and the Commission. Official Journal of the European Union, L 102, 11.4.2006, p. 15-34 // EUR-Lex. URL: https://eur-lex.europa.eu/legalcontent/EN/TXT/?uri=CELEX\%3A32006L0021.

193. Directive 2006/12/EC of the European Parliament and of the Council of 5 April 2006 on waste. Official Journal of the European Union, L 114, 27.4.2006, p. 9-21// EUR-Lex. URL: https://eur-lex.europa.eu/legal-content/EN/TXT/?uri= CELEX\%3A32006L0012.

194. Directive 2008/1/EC of the European Parliament and of the Council of 15 January 2008 concerning integrated pollution prevention and control (Codified version). Official Journal of the European Union, L 24, 29.1.2008, p. 8-29 // EUR-Lex. URL: https://eur-lex.europa.eu/legal-content/EN/TXT/?uri= CELEX\%3A32008L0001.

195. Directive 2008/98/EC of the European Parliament and of the Council of 19 November 2008 on waste and repealing certain Directives. Official Journal of the European Union, L 312, 22.11.2008, p. 3-30 // EUR-Lex. URL: https://eurlex.europa.eu/legal-content/EN/TXT/?uri=celex\%3A32008L0098.

196. Directive 2010/75/EU of the European Parliament and of the Council of 24 November 2010 on industrial emissions (integrated pollution prevention and control). Official Journal of the European Union, L 334/17. 2010. p. 17-119 // EUR-Lex. URL: https://eur-lex.europa.eu/legal-content/EN/TXT/?uri= CELEX\%3A32010L0075. 
ПРИЛОЖЕНИЕ 


\section{ПЕРЕЧЕНЬ ССЫЛОЧНЫХ НАЦИОНАЛЬНЫХ И МЕЖГОСУДАРСТВЕННЫХ СТАНДАРТОВ}

ГОСТ Р 57677-2017. Ресурсосбережение. Обращение с отходами. Ликвидация отходов недропользования : национальный стандарт Российской Федерации : официальное издание : дата введения 2018-05-01. Москва: Стандартинформ, 2019.

ГОСТ Р 54098-2010. Ресурсосбережение. Вторичные материальные ресурсы. Термины и определения : национальный стандарт Российской Федерации : официальное издание : дата введения 2012-01-01. Москва: Стандартинформ, 2019.

ГОСТ Р 52104-2003. Ресурсосбережение. Термины и определения : национальный стандарт Российской Федерации : официальное издание : дата введения 2004-07-01 (с изменениями, введенными 2012-01-01). Москва: ИПК Издательство стандартов, 2003.

ГОСТ Р 53691-2009. Ресурсосбережение. Обращение с отходами. Паспорт отхода I-IV класса опасности. Основные требования : национальный стандарт Российской Федерации : официальное издание : дата введения 201101-01. Москва: Стандартинформ, 2019.

ГОСТ Р ИСО 14050-2009. Менеджмент окружающей среды. Словарь : национальный стандарт Российской Федерации : официальное издание : дата введения 2010-11-01. Москва: Стандартинформ, 2011.

ГОСТ Р 55100-2012. Ресурсосбережение. Наилучшие доступные технологии обращения с отходами в горнодобывающей промышленности. Аспекты эффективного применения : национальный стандарт Российской Федерации : официальное издание : дата введения 2013-06-01. Москва: Стандартинформ, 2019.

ГОСТ Р 53692-2009. Ресурсосбережение. Обращение с отходами. Этапы технологического цикла отходов : национальный стандарт Российской Федерации : официальное издание : дата введения 2012-01-01. Москва: Стандартинформ, 2019.

ГОСТ Р 56828.15-2016. Наилучшие доступные технологии. Термины и определения : национальный стандарт Российской Федерации : официальное издание : дата введения 2017-07-01. Москва: Стандартинформ, 2019.

ГОСТ Р 56828.14-2016. Наилучшие доступные технологии. Структура информационно-технического справочника : национальный стандарт Российской Федерации : официальное издание : дата введения 2017-07-01. Москва: Стандартинформ, 2019.

ГОСТ 30772-2001. Ресурсосбережение. Обращение с отходами. Термины и определения : межгосударственный стандарт : официальное издание : дата введения 2002-07-01. Москва: ИПК Издательство стандартов, 2002.

ГОСТ 30775-2001. Ресурсосбережение. Обращение с отходами. Классификация, идентификация и кодирование отходов. Основные положения : межгосударственный стандарт : официальное издание : дата введения 2002-07-01. Москва: ИПК Издательство стандартов, 2002.

ГОСТ 33570-2015. Ресурсосбережение. Обращение с отходами. Методология идентификации. Зарубежный опыт : межгосударственный стандарт : официальное издание : дата введения 2016-08-01. Москва: Стандартинформ, 2016. 


\section{НАЦИОНАЛЬНЫЕ СТАНДАРТЫ В ОБЛАСТИ НАИЛУЧШИХ ДОСТУПНЫХ ТЕХНОЛОГИЙ}

ГОСТ Р 56828.1-2015. Наилучшие доступные технологии. Методические рекомендации по описанию перспективных технологий в информационно-техническом справочнике по наилучшим доступным технологиям : национальный стандарт Российской Федерации : официальное издание : дата введения 2016-09-01. Москва: Стандартинформ, 2019.

ГОСТ Р 56828.2-2015. Наилучшие доступные технологии. Методические рекомендации представления информации по экономическим аспектам реализации наилучших доступных технологий в информационнотехническом справочнике по наилучшим доступным технологиям : национальный стандарт Российской Федерации : официальное издание : дата введения 2016-09-01. Москва: Стандартинформ, 2019.

ГОСТ Р 56828.3-2015. Наилучшие доступные технологии. Методические рекомендации по представлению в информационно-техническом справочнике по наилучшим доступным технологиям информации по технологическому оборудованию : национальный стандарт Российской Федерации : официальное издание : дата введения 2016-09-01. Москва: Стандартинформ, 2019.

ГОСТ Р 56828.4-2015. Наилучшие доступные технологии. Подходы к проведению сравнительного анализа ресурсоэффективности и экологической результативности предприятий для предупреждения или минимизации негативного воздействия на окружающую среду : национальный стандарт Российской Федерации : официальное издание : дата введения 2016-09-01. Москва: Стандартинформ, 2019.

ГОСТ Р 56828.5-2015. Наилучшие доступные технологии. Методические рекомендации по порядку применения информационно-технического справочника по наилучшим доступным технологиям при оценке воздействия проектируемых предприятий на окружающую среду : национальный стандарт Российской Федерации : официальное издание : дата введения 2016-09-01. Москва: Стандартинформ, 2019.

ГОСТ Р 56828.6-2015. Наилучшие доступные технологии. Методические рекомендации по порядку применения информационно-технического справочника по наилучшим доступным технологиям при оценке (экспертизе, конкурсном отборе) проектов модернизации предприятий, направленных на достижение требований наилучших доступных технологий (внедрение НДТ) : национальный стандарт Российской Федерации : официальное издание : дата введения 2016-09-01. Москва: Стандартинформ, 2019.

ГОСТ Р 56828.7-2015. Наилучшие доступные технологии. Методические рекомендации представления информации по текущим уровням выбросов / сбросов загрязняющих веществ (эмиссий) и потребления ресурсов в информационнотехническом справочнике по наилучшим доступным технологиям : национальный стандарт Российской Федерации : официальное издание : дата введения 2016-09-01. Москва: Стандартинформ, 2019.

ГОСТ Р 56828.8-2015. Наилучшие доступные технологии. Методические рекомендации по описанию наилучших доступных технологий в информационнотехническом справочнике по наилучшим доступным технологиям (Переиздание) : национальный стандарт Российской Федерации : официальное издание : дата введения 2016-09-01. Москва: Стандартинформ, 2019. 
ГОСТ Р 56828.9-2015. Наилучшие доступные технологии. Методические рекомендации по проведению сравнительного анализа производств при разработке информационно-технического справочника по наилучшим доступным технологиям : национальный стандарт Российской Федерации : официальное издание : дата введения 2016-09-01. Москва: Стандартинформ, 2019.

ГОСТ Р 56828.10-2015. Наилучшие доступные технологии. Методические рекомендации по актуализации информационно-технического справочника по наилучшим доступным технологиям : национальный стандарт Российской Федерации : официальное издание : дата введения 2016-09-01. Москва: Стандартинформ, 2019.

ГОСТ Р 56828.11-2015. Наилучшие доступные технологии. Методические рекомендации по разработке раздела информационно-технического справочника по наилучшим доступным технологиям по описанию приоритетных проблем отрасли : национальный стандарт Российской Федерации : официальное издание : дата введения 2016-09-01. Москва: Стандартинформ, 2019.

ГОСТ Р 56828.13-2016. Наилучшие доступные технологии. Формат описания технологий : национальный стандарт Российской Федерации : официальное издание : дата введения 2016-10-25. Москва: Стандартинформ, 2019.

ГОСТ Р 56828.14-2016. Наилучшие доступные технологии. Структура информационно-технического справочника : национальный стандарт Российской Федерации : официальное издание : дата введения 2017-07-01. Москва: Стандартинформ, 2019.

ГОСТ Р 56828.15-2016. Наилучшие доступные технологии. Термины и определения : национальный стандарт Российской Федерации : официальное издание : дата введения 2017-07-01. Москва: Стандартинформ, 2019.

ГОСТ Р 56828.16-2017. Наилучшие доступные технологии. Энергосбережение. Методология планирования показателей (индикаторов) энергоэффективности : национальный стандарт Российской Федерации : официальное издание : дата введения 2017-12-01. Москва: Стандартинформ, 2019.

ГОСТ Р 56828.17-2017. Наилучшие доступные технологии. Ресурсосбережение. Стратегии и методы термической обработки опасных отходов : национальный стандарт Российской Федерации : официальное издание : дата введения 2017-12-01. Москва: Стандартинформ, 2019.

ГОСТ Р 56828.19-2017. Наилучшие доступные технологии. Энергосбережение. Методология идентификации показателей энергоэффективности : национальный стандарт Российской Федерации : официальное издание : дата введения 2017-12-01. Москва: Стандартинформ, 2019.

ГОСТ Р 56828.22-2017. Наилучшие доступные технологии. Ресурсосбережение. Стратегии, принципы и методы экологически ориентированного обращения с отходами : национальный стандарт Российской Федерации : официальное издание : дата введения 2017-12-01. Москва: Стандартинформ, 2019.

ГОСТ Р 56828.24-2017. Наилучшие доступные технологии. Энергосбережение. Руководство по применению наилучших доступных технологий для повышения энергоэффективности : национальный стандарт Российской Федерации : официальное издание : дата введения 2018-02-01. Москва: Стандартинформ, 2019.

ГОСТ Р 56828.27-2017. Наилучшие доступные технологии. Ресурсосбережение. Методология обработки отходов в целях получения вторичных 
материальных ресурсов : национальный стандарт Российской Федерации : официальное издание : дата введения 2018-02-01. Москва: Стандартинформ, 2019.

ГОСТ Р 56828.29-2017. Наилучшие доступные технологии. Энергосбережение. Порядок определения показателей (индикаторов) энергоэффективности : национальный стандарт Российской Федерации : официальное издание : дата введения 2017-02-01. Москва: Стандартинформ, 2019.

ГОСТ Р 56828.30-2017. Наилучшие доступные технологии. Ресурсосбережение. Методология обработки отходов в целях получения вторичных топливно-энергетических ресурсов : национальный стандарт Российской Федерации : официальное издание : дата введения 2018-02-01. Москва: Стандартинформ, 2019.

ГОСТ Р 56828.31-2017. Наилучшие доступные технологии. Ресурсосбережение. Иерархический порядок обращения с отходами : национальный стандарт Российской Федерации : официальное издание : дата введения 2017-12-01. Москва: Стандартинформ, 2019.

ГОСТ Р 56828.32-2017. Наилучшие доступные технологии. Ресурсосбережение. Методологии идентификации : национальный стандарт Российской Федерации : официальное издание : дата введения 2017-12-01. Москва: Стандартинформ, 2019.

ГОСТ Р 56828.34-2017. Наилучшие доступные технологии. Ресурсосбережение. Методология принятия управленческих решений для сохранения водных биоресурсов и среды их обитания : национальный стандарт Российской Федерации : официальное издание : дата введения 2018-03-01. Москва: Стандартинформ, 2019.

ГОСТ Р 56828.35-2018. Наилучшие доступные технологии. Водопользование. Термины и определения : национальный стандарт Российской Федерации : официальное издание : дата введения 2019-01-01. Москва: Стандартинформ, 2019.

ГОСТ Р 56828.37-2018. Наилучшие доступные технологии. Нормирование. Термины и определения : национальный стандарт Российской Федерации : официальное издание : дата введения 2019-01-01. Москва: Стандартинформ, 2019.

ГОСТ Р 56828.38-2018. Наилучшие доступные технологии. Окружающая среда. Термины и определения : национальный стандарт Российской Федерации : официальное издание : дата введения 2019-01-01. Москва: Стандартинформ, 2019.

ГОСТ Р 56828.39-2018. Наилучшие доступные технологии. Производственные аспекты. Термины и определения : национальный стандарт Российской Федерации : официальное издание : дата введения 2019-01-01. Москва: Стандартинформ, 2019.

ГОСТ Р 56828.40-2018. Наилучшие доступные технологии. Размещение отходов. Термины и определения : национальный стандарт Российской Федерации : официальное издание : дата введения 2019-01-01. Москва: Стандартинформ, 2019.

ГОСТ Р 113.00.01-2019. Наилучшие доступные технологии. Система стандартов наилучших доступных технологий. Общие положения : национальный стандарт Российской Федерации : официальное издание : дата введения 2019-08-01. Москва: Стандартинформ, 2019. 
